STRUCTURE AND STRATIGRAPHY OF THE CENTRAL, NORTHERN, AND EASTERN PARTS OF THE TUCSON BASIN, ARIZONA by Emil Frederick Pashley, Jr.

A Dissertation Submitted to the Faculty of the DEPARTMENT OF GEOLOGY In Partial Fulfillment of the Requirements For the Degree of DOCTOR OF PHILOSOPHY In the Graduate College THE UNIVERSITY OF ARIZONA 


\section{THE UNIVERSITY OF ARIZONA}

\section{GRADUATE COLLEGE}

I hereby recommend that this dissertation prepared under my direction by Emil Frederick Pashley, Jr., entitled "Structure and Stratigraphy of the Central, Northern, and Eastern Parts of the Tucson Basin, Arizona" be accepted as fulfilling the dissertation requirement of the degree of Doctor of Philosophy.

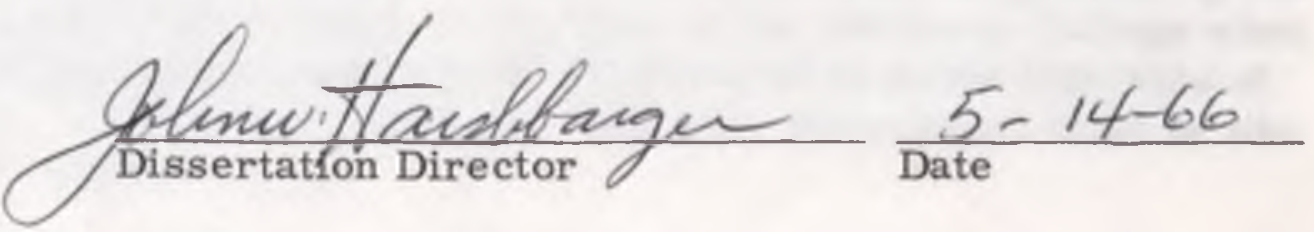

After inspection of the dissertation, the following members of the Final Examination Committee concur in its approval and recommend its acceptance:*
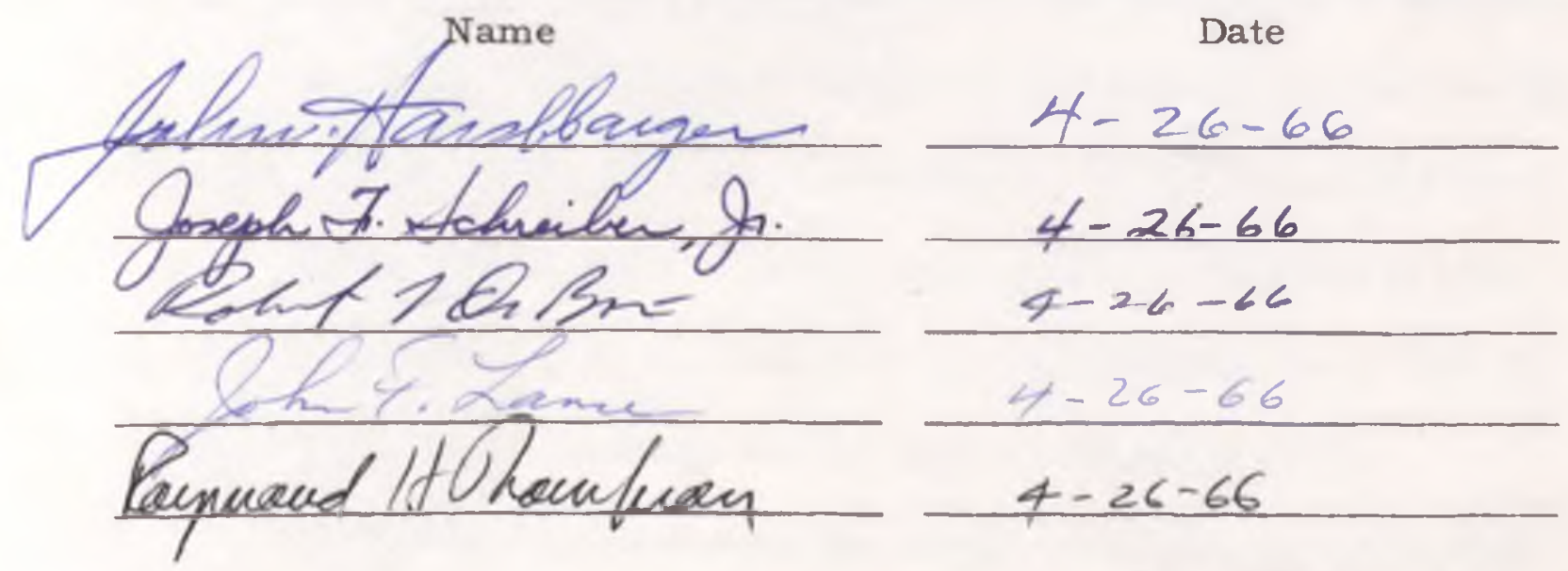

* This approval and acceptance is contingent on the candidate's adequate performance and defense of this dissertation at the final oral examination. The inclusion of this sheet bound into the library copy of the dissertation is evidence of satisfactory performance at the final examination. 


\section{STATEMENT BY AUTHOR}

This dissertation has been submitted in partial fulfillment of requirements for an advanced degree at The University of Arizona and is deposited in the University Library to be made available to borrowers under rules of the Library.

Brief quotations from this dissertation are allowable without special permission, provided that accurate acknowledgment of source is made. Requests for permission for extended quotation from or reproduction of this manuscript in whole or in part may be granted by the head of the major department or the Dean of the Graduate College when in his judgment the proposed use of the material is in the interests of scholarship. In all other instances, however, permission must be obtained from the author.

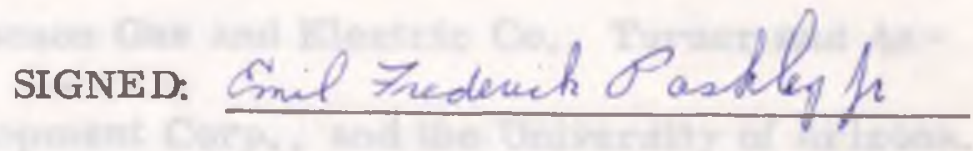




\section{ACKNOWLEDGMENTS}

The material that comprises this dissertation was collected by the author while employed by the Arizona district of the Water Resources Division, U.S. Geological Survey. The investigation was conducted under the general supervision of J. W. Harshbarger, P. E. Dennis, and H. M. Babcock, successive chiefs of the Arizona district. Dr. Harshbarger also served in the additional capacity of thesis director.

The investigation was aided by the cooperation of many agencies and individuals. Well cuttings were provided by the city of Tucson Water Department, the Tucson Gas and Electric Co., Turner and Associates, the Water Development Corp., and the University of Arizona. Especial thanks are due the local water-well drilling companies and the individual drillers who, without remuneration, collected cuttings from many privately owned wells. Notable among these companies are the Forsyth Drilling Co., A. A. McDaniel Well and Machine Co., Carl W. Pistor, A. L. Cotton Boring, and the Arizona Maintenance Co. Dewey Hicks coordinated the sample-collection program with the drillers and processed the majority of the samples in the laboratory. J. L. Olson, J. S. Phelps, I. W. Couse, and H. H. Schumann 
also aided in the sample processing at various times. Part-time laboratory help and permanent sample-storage space was provided by the Arizona Bureau of Mines. The drafting was done by G. S. Smith, J. R. Dusard, F. H. Rascop, and W. D. Potts. The manuscript was typed by C. L. Hicks and H. S. Price.

I have benefited greatly from the advice and thoughtful discussion concerning the structure and stratigraphy of southern Arizona proffered me by my colleagues E. S. Davidson and M. E. Cooley of the Geological Survey and J. F. Lance of the University of Arizona. I have also benefited from the advice, questions, and criticisms of E. B. Mayo, H. W. Peirce, J. F. Schreiber, G. E. Maddox, J. R. Cooper, R. L. DuBois, C. L. Fair, L. A. Heindl, and D. P. Elston. The friendly assistance and cooperation of H. C. Schwalen, R. J. Shaw, and W. G. Matlock of the Department of Agricultural Engineering, University of Arizona, is gratefully acknowledged. 


\section{TABLE OF CONTENTS}

Page

LIST OF ILLUSTRATIONS $\ldots \ldots \ldots \ldots \ldots \ldots \ldots \ldots \ldots \ldots$ ix

LIST OF TABLES $\ldots \ldots \ldots \ldots \ldots \ldots \ldots \ldots \ldots \ldots \ldots \ldots \ldots \ldots \ldots \ldots \ldots \ldots$ xiii

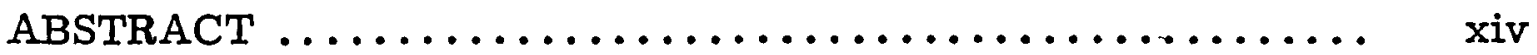

INTRODUCTION $\ldots \ldots \ldots \ldots \ldots \ldots \ldots \ldots \ldots \ldots \ldots \ldots \ldots \ldots \ldots$

The Rillito Project $\ldots \ldots \ldots \ldots \ldots \ldots \ldots \ldots \ldots \ldots \ldots \ldots, 1$

Purpose and Scope $\ldots \ldots \ldots \ldots \ldots \ldots \ldots \ldots \ldots \ldots \ldots \ldots \ldots$

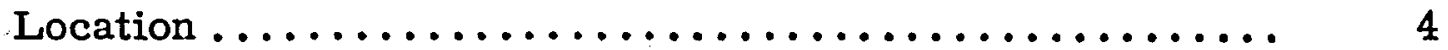

Organization of the Report $\ldots \ldots \ldots \ldots \ldots \ldots \ldots \ldots \ldots \ldots, 4$

THE INTERNAL STRUCTURE OF THE RINCON, TANQUE

VERDE, AND SOUTHERN FORERANGE OF THE SANTA

CATALINA MOUNTAINS ..................... 8

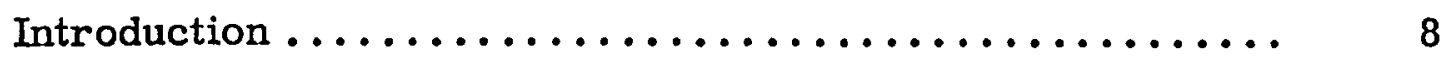

Catalina Gneiss $\ldots \ldots \ldots \ldots \ldots \ldots \ldots \ldots \ldots \ldots \ldots \ldots, 9$

Definition, Areal Extent, and Lithology .......... 9

Foliation and Layering $\ldots \ldots \ldots \ldots \ldots \ldots \ldots \ldots \ldots . \ldots \ldots$

Origin and Age ........................ 13

Folds in the Catalina Gneiss ................. 16

Previous Work ...................... 16

Method of Investigation and Interpretation ......... 16

Pusch Ridge Anticline .................... 22

Folds Between Pusch Ridge and Sabino Canyon ....... 23

Sabino-Bear Canyon Anticline ............... 26

Molino Canyon Anticline .................. 29

La Milagrosa Syncline .................... 29

Folds in the Agua Caliente Hill-Tanque Verde

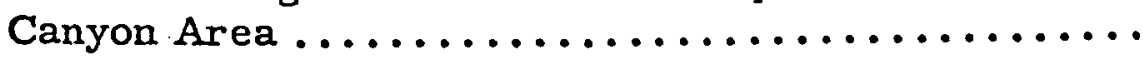


TABLE OF CONTENTS- Continued

Page

Tanque Verde Anticline .................. 31

Rincon Valley Syncline ................... 32

Folds in the Southern Rincon Mountains ......... 32

Reflection of the Folds in the Physiography ......... 33

Previous Work......................... 33

Revised Interpretation $\ldots \ldots \ldots \ldots \ldots \ldots \ldots \ldots . \quad 34$

THE CATALINA FAULT $\ldots \ldots \ldots \ldots \ldots \ldots \ldots \ldots \ldots \ldots \ldots ., 38$

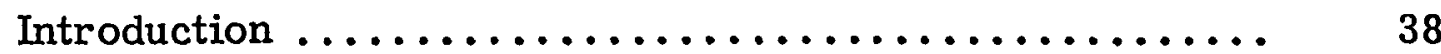

Previous Work ........................... 38

The Trace of the Catalina Fault ................ 39

Parallelism Between the Fault and the Folds in the

Gneiss ................................. 40

Rocks of the Upper Plate $\ldots \ldots \ldots \ldots \ldots \ldots \ldots \ldots \ldots \ldots \ldots$

Folded Rocks of Pre-Late Tertiary Age ......... 43

Fractured Rocks of Late Tertiary Age .......... 45

Hypothesis Regarding Two Periods of Displacement .... 46

First Period-Thrusting and Folding.......... 46

Second Period-Normal Faulting ............. 49

Wells and Springs Along the Catalina Fault ......... 56

GEOLOGY OF THE PLEDMONT REGION $\ldots \ldots \ldots \ldots \ldots \ldots \ldots, 61$

Stratigraphy and Structure of the Rillito Beds ........ 61

Introduction .......................... 61

Definition and Distribution ................ 63

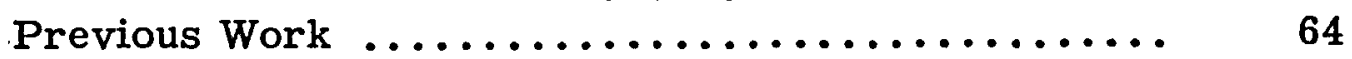

Subdivisions Used in This Report ............. 66

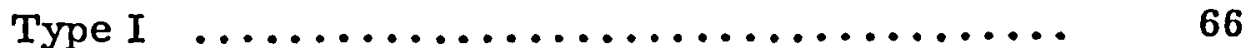

Type II $\ldots \ldots \ldots \ldots \ldots \ldots \ldots \ldots \ldots \ldots \ldots \ldots \ldots, 72$ 
TABLE OF CONTENTS-Continued

Page

Type $\mathrm{III} \ldots \ldots \ldots \ldots \ldots \ldots \ldots \ldots \ldots \ldots \ldots \ldots$

Stratigraphic Relations $\ldots \ldots \ldots \ldots \ldots \ldots \ldots \ldots$ Origin $\ldots \ldots \ldots \ldots \ldots \ldots \ldots \ldots \ldots \ldots \ldots \ldots \ldots \ldots$

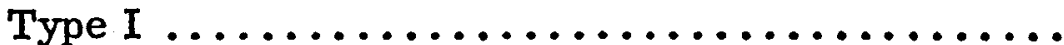

Age and Correlation $\ldots \ldots \ldots \ldots \ldots \ldots \ldots \ldots \ldots \ldots, 88$

Major Normal Faults ..................... 91

Minor Normal Faults .................... 93

Bedding Attitudes ...................... 98

Folds and Reverse Faults .................. 98

The Rillito Surface ......................... 100

Basin-Fill Deposits ......................... 111

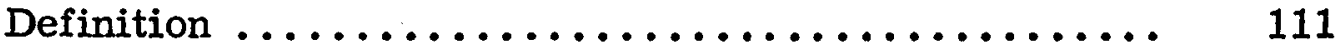

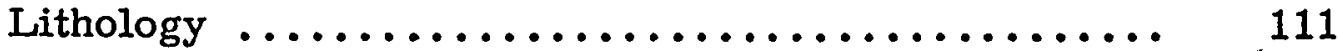

Exposure 1 of Basal Basin Fill ............ 116

Exposure 2 of Basal Basin Fill .............. 118

Exposure 1 of Basin Fill ................. 119

Exposure 2 of Basin Fill ................ 120

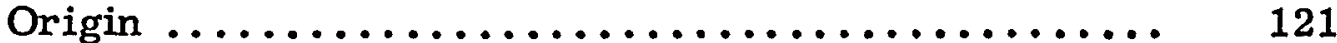

Areal Extent-Present and Past .............. 123

Age and Correlation .................... 128

Terraces and Terrace Deposits ............... 129

Introduction ......................... 129

Previous Work ....................... 130

Reinterpretation of Smith's Terraces .......... 133

History of Rillito Creek .................. 135

Broad Terraces Along the Margins of the Basin ..... 136

Level I ........................ 137 
viii

TABLE OF CONTENTS- Continued

Page

Level II . . . . . . . . . . . . . . . . . . .

Terraces Along Pantano Wash and South of Tucson..

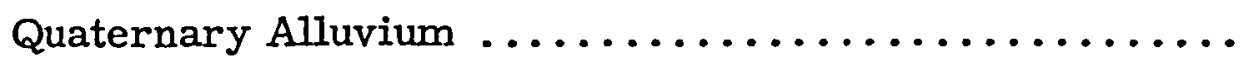

Definition and Lithology $\ldots \ldots \ldots \ldots \ldots \ldots \ldots \ldots$

Thickness

SUBSURFACE GEOLOGY ...................

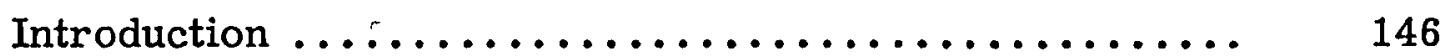

Rillito Creek Area ....................... 147

Canada del Oro Area ........................... 148

Sabino Creek Area ....................... 152

Pantano Wash Area ....................... 152

Santa Cruz River Area ........................ 153

Central Tucson Area ........................ 154

The Power Company Wells ................... 154

EVOLUTION OF THE TUCSON BASIN . ............. 156

Introduction $\ldots \ldots \ldots \ldots \ldots \ldots \ldots \ldots \ldots \ldots \ldots \ldots \ldots . \ldots \ldots$

Early and Middle Tertiary Deformation ........... 157

Middle and Late Tertiary Uplift, Erosion, Deposition, and Faulting $\ldots \ldots \ldots \ldots \ldots \ldots \ldots \ldots \ldots \ldots \ldots \ldots \ldots$

Late Tertiary and Early Quaternary Erosion and

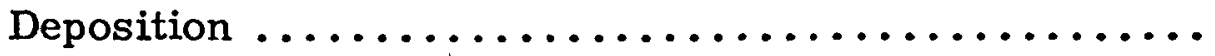
Middle and Late Quaternary Basin Erosion ..........

APPENDIX A-WELL-CUTTINGS ANALYSES ......... 163

LITERATURE CITED $\ldots \ldots \ldots \ldots \ldots \ldots \ldots \ldots \ldots \ldots \ldots \ldots \ldots .269$ 


\section{LIST OF ILLUSTRATIONS}

Figure

Page

1. Index map of Arizona showing the location of the area shown on plate $1 \ldots \ldots \ldots \ldots \ldots \ldots \ldots \ldots \ldots$

2. Well-numbering system in Arizona .............. 6

3. Areal distribution of the Catalina Gneiss ........... 10

4. Marble interbedded with gneiss .................. 12

5. Lineation in the Catalina Gneiss ............... 20

6. Pusch Ridge anticline ....................... 24

7. Anticlinal fold, Pima Canyon ................. 25

8. Sabino and Bear Canyons ................... 27

9. Folds in the Tanque Verde Mountains-Agua Caliente Hill region ........................ 30

10. Generalized map showing border faults offset by transverse faults as an explanation for the configuration of the fronts of the ranges ...........

11. Generalized diagram showing the restored folds in the Santa Catalina, Tanque Verde, and Rincon Mountains ..........................

12. Folds in Paleozoic rocks of the upper plate ......... 44

13. Folded pre-late Tertiary rocks of the upper plate ..... 50

14. Catalina fault, Tanque Verde Mountains ........... 51

15. Catalina fault, southwest Rincon Mountains .......... 52 
LIST OF ILLUSTRATIONS-Continued

Figure

Page

16. Catalina fault, southern Rincon Mountains ......... 53

17. Catalina fault, southern Rincon Mountains ......... 54

18. Plane of the Catalina fault................. 55

19. Fan remnants, exhumed pediment, and the Catalina

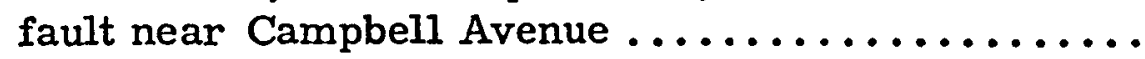

20. Generalized north-south geologic cross section across the southern front of the Santa Catalina Mountains, showing the relation of well-site locations to

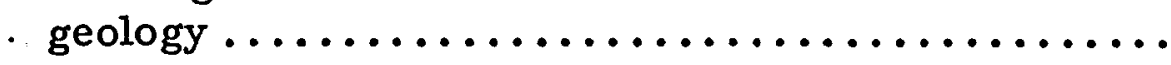

21. Index map showing fault blocks

22. Areal distribution of conglomerate, sandstone, and mudstone of the Rillito beds ................

23. Type I Rillito beds $\ldots \ldots \ldots \ldots \ldots \ldots \ldots \ldots \ldots \ldots$

24. Type II Rillito beds $\ldots \ldots \ldots \ldots \ldots \ldots \ldots \ldots \ldots \ldots$

25. Type III Rillito beds $\ldots \ldots \ldots \ldots \ldots \ldots \ldots \ldots \ldots \ldots \ldots . \quad 80$

26. Type III Rillito beds $\ldots \ldots \ldots \ldots \ldots \ldots \ldots \ldots \ldots \ldots . . . \ldots 1$

27. Strike and dip diagrams for minor faults for blocks

$A, B$, and $C \ldots \ldots \ldots \ldots \ldots \ldots \ldots \ldots \ldots \ldots \ldots \ldots \ldots \ldots \ldots \ldots$

28. Strike and dip diagrams for minor faults for blocks

$D, F$, and $I \ldots \ldots \ldots \ldots \ldots \ldots \ldots \ldots \ldots \ldots \ldots \ldots \ldots \ldots \ldots \ldots \ldots \ldots$

29. Strike and dip diagrams for minor faults for block N..

30. Generalized bedding attitudes within the fault blocks ..

31. The Rillito surface $\ldots \ldots \ldots \ldots \ldots \ldots \ldots \ldots \ldots$ 
LIST OF ILLUSTRATIONS- Continued

Figure

Page

32. Pediment and alluvial fans ................ 106

33. Pediment bench $\ldots \ldots \ldots \ldots \ldots \ldots \ldots \ldots \ldots \ldots \ldots \ldots . . \ldots$

34. Dissected pediment bench $\ldots \ldots \ldots \ldots \ldots \ldots \ldots \ldots \ldots . . \ldots 9$

35. Basin-fill deposits $\ldots \ldots \ldots \ldots \ldots \ldots \ldots \ldots \ldots \ldots \ldots . \quad 112$

36. Basal basin-fill deposits $\ldots \ldots \ldots \ldots \ldots \ldots \ldots \ldots \ldots . \quad 115$

37. Coarse boulder facies of the basin-fill deposits ..... 124

38. Map showing the areal distribution of the University, Cemetery, and Jaynes terraces, bottom land, and the thicknesses of terrace deposits and Quaternary alluvium at well sites $\ldots \ldots \ldots \ldots \ldots \ldots \ldots \ldots \ldots$

39. Diagram showing Smith's interpretation of the

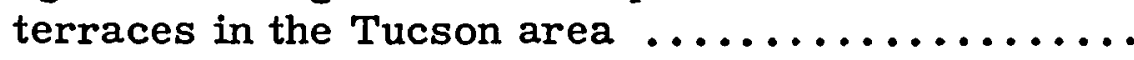

40. Geologic cross section across Rillito Creek along Campbell Avenue showing the relation of physi-

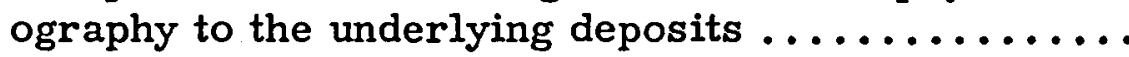

41. Terrace deposits $\ldots \ldots \ldots \ldots \ldots \ldots \ldots \ldots \ldots \ldots$

42. Cross section along Wentworth Road between

Speedway Boulevard and Tanque Verde Road .......

43. The Pịate fault $\ldots \ldots \ldots \ldots \ldots \ldots \ldots \ldots \ldots \ldots \ldots . \quad 150$

44. . Type III Rillito bed equivalents .............. 151

Plate

1. Geologic map of the northern and eastern parts of the Tucson basin, Arizona ............... in pocket 


\section{LIST OF ILLUSTRATIONS-Continued}

Plate

2. Geologic sections in the northern part of the Tucson basin, Arizona ...................... in pocket

3. Map showing the extent of the basin-fill deposits, the Rillito surface, and drainage basins in the northern and eastern parts of the Tucson basin,

Arizona in pocket

4. Map showing contours on the base of the basin-fill deposits, Tucson basin, Arizona ............. in pocket

5. Map showing terraces in the northern, eastern, and central parts of the Tucson basin, Arizona .... in pocket 


\section{LIST OF TABLES}

Table

Page

1. Summary of previous work concerning the age of metamorphism of and the rocks involved in the formation of the Catalina Gneiss .............

2. Summary of previous work concerning folds in the Catalina, Tanque Verde, and Rincon Mountains ...

3. Summary of previous work concerning the lineation in the Catalina Gneiss ..................

4. Summary of dip measurements on the Catalina fault

5. Summary of the lithology of the fault blocks

6. Pebble counts of type I of the Rillito beds ..........

7. Pebble counts of type II of the Rillito beds ........

8. Pebble counts of type III of the Rillito beds ........ 82

9. Pebble counts of basin-fill exposures ............ 


\section{STRUCTURE AND STRATIGRAPHY OF THE CENTRAL, NORTHERN, AND EASTERN PARTS OF THE TUCSON BASIN, ARIZONA}

By

Emil Frederick Pashley, Jr.

\section{ABSTRACT}

The Tucson basin is bordered on the north and east by the Santa Catalina, Tanque Verde, and Rincon Mountains. Their shape reflects their internal structure, a series of broad west-southwest-trending and plunging anticlines and synclines formed from the layers of the granitic Catalina Gneiss. The ranges and their structures were formed during a period of intrusion, metamorphism, folding, and thrust faulting that probably started in Late Cretaceous or early Tertiary time and continued into middle Tertiary time.

The Catalina fault lies along the base of the ranges, dips basinward at a low angle, and separates the gneiss of the ranges from unmetamorphosed rocks of the piedmont region. The fault surface conforms to the folds in the underlying gneiss and appears to have originated 
as a bedding thrust during early to middle Tertiary folding. Locally, the upper plate is composed of intensely folded rocks of Cretaceous age and older. It is suggested that these folds were formed by thrusting along the Catalina fault. At many places the upper plate is composed of the Rillito beds of probable middle and late Tertiary age. The Rillito beds have been broken by normal faults into a series of tilted blocks. These normal faults merge horizontally and vertically with the Catalina fault. Normal movement along these faults resulted in the Rillito beds being brought into contact with the Catalina Gneiss along the pre-existing Catalina fault. These normal faults did not offset the Catalina fault or the gneiss of the ranges that has acted as a single rigid block since middle Tertiary time.

The type I (oldest) and type II (second oldest) Rillito beds consist of red conglomerate and mudstone deposited during early stages of the uplift and erosion of the modern ranges. Their basin of deposition extended to the edges of the rising highlands whose boundaries were located well within the limits of the modern ranges. The pebble composition of these beds reflects the gradual uncovering of the Catalina Gneiss within the cores of the rising highlands; gneiss pebbles are scarce in type I and common in type II Rillito beds.

The type III Rillito beds were deposited along the edges of the ranges after they had reached their approximate present configuration. They are composed of gneiss pebbles derived from the modern ranges 
and of material eroded from the type I and type II Rillito beds involved in the uplift. The beds consist of sand and gravel deposited along the edge of the ranges as alluvial fans and merge near the center of the basin with fine-grained playa deposits.

The close of Rillito deposition was marked by normal faulting and erosion within the piedmont area. The erosion destroyed any faultblock topography that may have existed, carved the Rillito surface across the Rillito beds, and formed narrow bedrock pediments along the edges of the ranges.

In late Tertiary and early Quaternary time, during and after the formation of the Rillito surface, the basin-fill deposits were laid down in a closed basin as alluvial fans that at one time extended from the steep fronts of the ranges to the center of the basin where they merged with fine-grained deposits and reached thicknesses in excess of 700 feet.

In middle Quaternary time the formation of a drainage outlet in the northwest corner of the basin resulted in increased stream gradients and the start of basin erosion. This resulted in the present drainage system, the formation of several broad erosion surfaces and river terraces, the exhumation of the bedrock pediments, and the removal of alluvial fans from along the mountain edges. This basin erosion is still in progress. 


\section{INTRODUCTION}

\section{The Rillito Project}

The city of Tucson is completely dependent upon ground water for its municipal water supply. In June 1959, the Rillito Creek Hydrologic Committee, composed of personnel of the University of Arizona and the Water Resources Division of the U.S. Geological Survey, released a report in which they proposed a series of investigations into the methods of capturing additional water in the Tucson area to supplement municipal supplies (The Rillito Creek Hydrologic Committee, 1959).

The proposed investigations were to be conducted over a period of 5 years by personnel of the Geological Survey and the University of Arizona. When sufficient funds did not become available to finance all the proposed investigations, the Geological Survey and the University of Arizona decided to proceed with some of the proposed investigations, but on a greatly reduced scale.

One.of the investigations proposed was a study of the geologic framework in the Rillito Creek area with particular reference to the thickness and distribution of the rock types and their structural 
attitude. It is this investigation that was undertaken by the author while employed by the Geological Survey; it is reported upon in this dissertation.

\section{Purpose and Scope}

The city of Tucson is dependent on ground water for its municipal water supplies. An evaluation of the quantity and the quality of these supplies is partly dependent upon knowledge of the structure and stratigraphy of the water-bearing rocks that underlie the basin.

In the central part of the basin, the area where most of the ground water is pumped, the water-bearing rocks are not exposed and can only be studied by the examination of cuttings collected during the drilling of wells.

Along the northern and eastern borders of the basin, north of Rillito Creek and east of Pantano Wash, extensive erosion has cut into and exposed many of the same rocks penetrated by wells in the central part of the basin. These exposures make it possible to work out the structure and stratigraphy of these rocks by conventional surface geologic techniques.

The purpose of the investigation, therefore, was to work out the structure and stratigraphy of the rocks exposed north of Rillito Creek and east of Pantano Wash by surface geologic mapping, to collect cuttings from wells drilled in the Tucson basin, and to interpret 
the well cuttings in terms of the structure and stratigraphy determined during the surface geologic mapping.

Detailed geologic mapping at a scale of $1: 48,000$ was carried out in the area bounded by the Santa Catalina and Tanque Verde Mountains on the north and east, U.S. Highway 89 on the west, and Rillito Creek and Pantano Wash on the south and southwest. Reconnaissance mapping, at the same scale, was carried out in the piedmont area along the northwest side of the Santa Catalina Mountains to aid in the interpretation of well cuttings collected from that area. The central part of the basin, south of Rillito Creek and west of Pantano Wash, was examined but not mapped.

The trace of the Catalina fault was mapped from its westernmost exposure along the south front of the Santa Catalina Mountains to its easternmost limit along the southern edge of the Rincon Mountains.

A reconnaissance investigation of the internal structure of those parts of the Santa Catalina, Tanque Verde, and Rincon Mountains that border on the Tucson basin was also conducted.

Well cuttings were collected from many wells in the Tucson basin. These cuttings were described and interpreted, and those of significance are included in the appendix in the form of sample logs. 


\section{Location}

The Tucson basin is in the Basin and Range physiographic province of southern Arizona. The parts of the basin described are included on the Mount Lemmon, Bellota Ranch, Tucson, and Rincon Valley quadrangles of the 15-minute topographic series (fig. 1) and are bounded by long $110^{\circ} 30^{\prime}$ and $111^{\circ} 00^{\prime} \mathrm{W}$. and lat $32^{\circ} 00^{\prime}$ and $32^{\circ} 30^{\prime} \mathrm{N}$.

The locations of wells and pebble counts referred to in this report are given in accordance with the system of land subdivision used by the Bureau of Land Management (fig. 2).

\section{Organization of the Report}

The report has been divided into five main sections and an appendix.

The first section deals with the internal structure of the Santa Catalina, Tanque Verde, and Rincon Mountains. It points out the close relation that exists between the shape of the ranges and the internal structure-a relation not generally thought to be typical of the mountains of the Basin and Range province of southern Arizona.

The second section describes the Catalina fault, a long continuous frontal fault that separates the gneissic rocks of the ranges from the rocks of the piedmont area. This fault, unlike the supposedly 


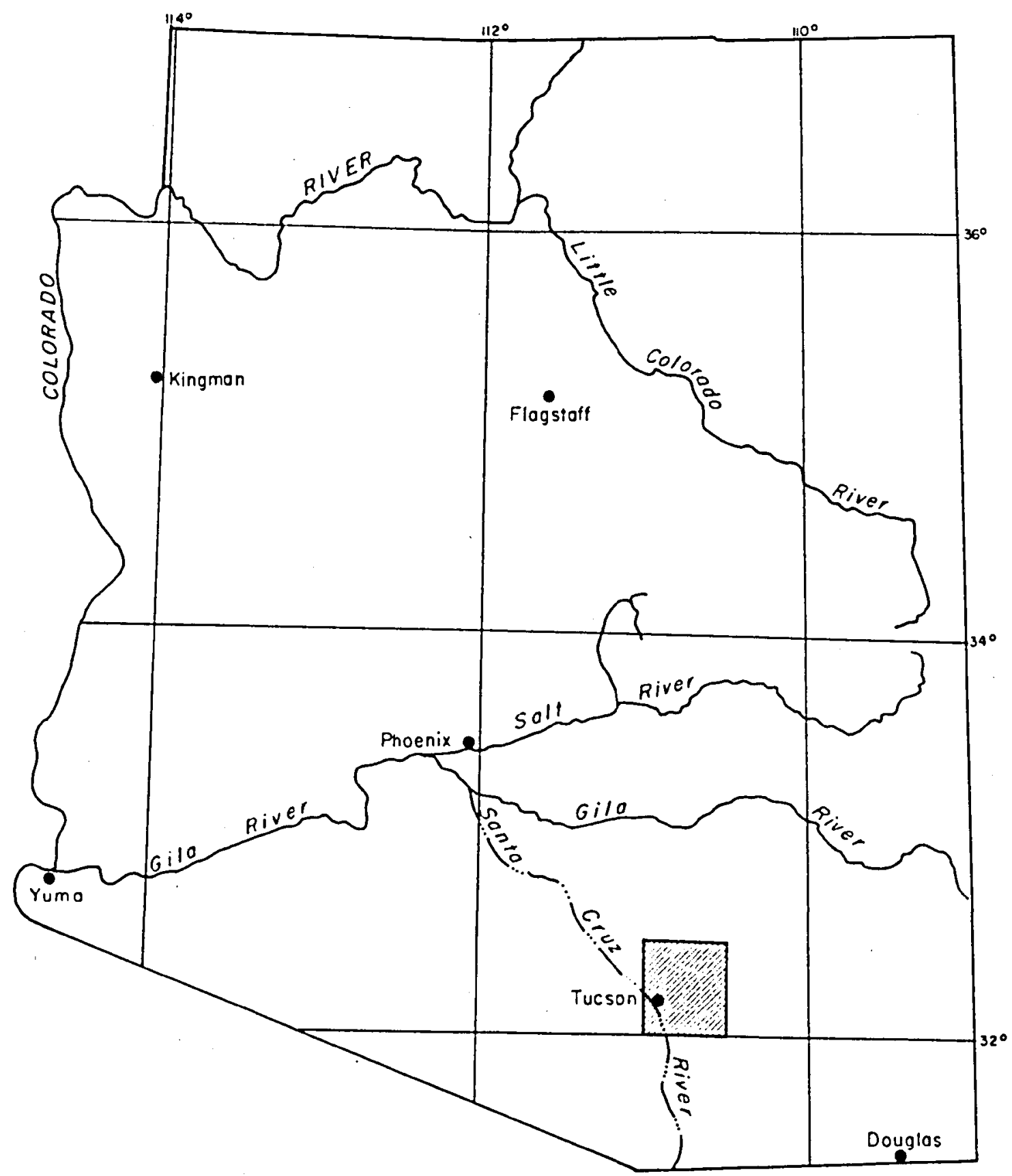

Figure 1.--Index map of Arizona showing the location of the area shown on plate 1 . 


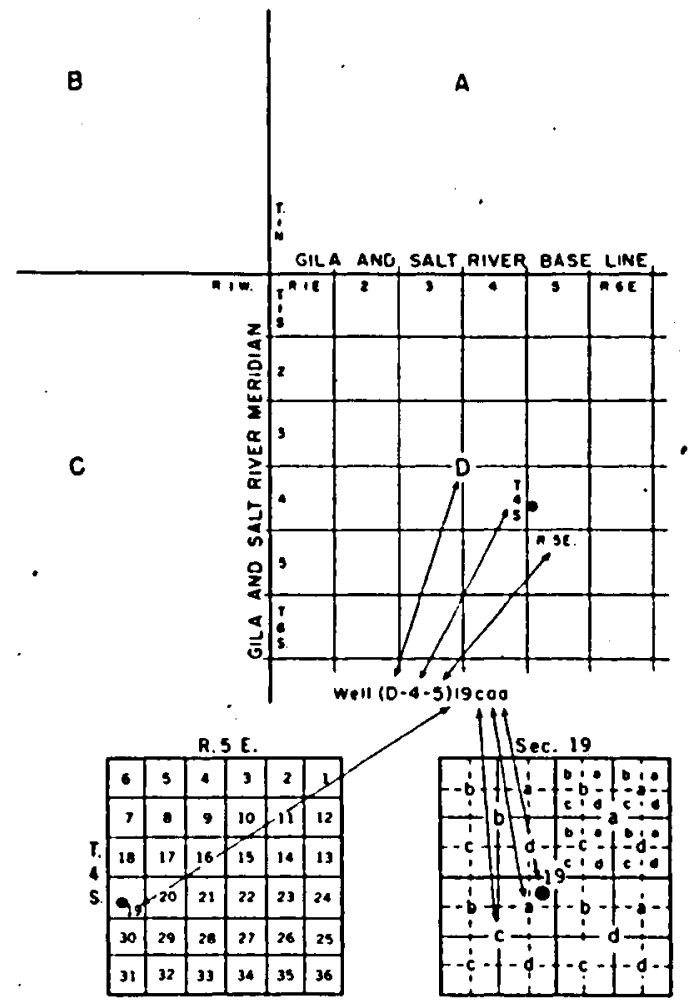

The well numbers used by the Geological Survey in Arizona are in accordance with the Bureau of Land Management's system of land subdivision. The land survey in Arizona is based on the Gila and Salt River meridian and base line, which divide the State into four quadrants. These quadrants are designated counterclockwise by the capital letters $A$, B, C, and D. All land north and east of the point of origin is in A quadrant, that north and west in $B$ quadrant, that south and west in $C$ quadrant, and that south and east in $D$ quadrant. The first digit of a well number indicates the township, the second the range, and the third the section in which the well is situated. The lowercase letters $a, b, c$, and $d$ after the section number indicate the well location within the section. The first letter denotes a particular 160-acre tract, the second the $40-$ acre tract, and the third the 10-acre tract. These letters also are as signed in a counterclockwise direction, beginning in the nor theast quarter. If the location is known within the 10-acre tract, three lowercase letters are shown in the well number. In the example shown, well number

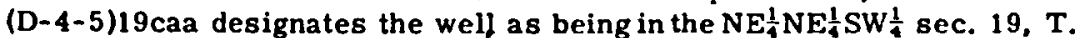
$4 \mathrm{~S}$., R. 5 E. Where there is more than one well within a 10-acre tract, consecutive numbers beginning with 1 are added as suffixes.

Figure 2. --Well-numbering system in Arizona. 
typical basin-and-range frontal faults, does not truncate the internal structure of the ranges but is instead parallel to it.

The third section describes the geology of the piedmont region. It contains descriptions of the structure, stratigraphy, and erosional history of the consolidated and unconsolidated rocks that underlie the Tucson basin and control the movement and storage of ground water.

The fourth section is a brief summary of the types of deposits encountered in wells in the Tucson basin. It is based on the examination of cuttings collected during the drilling of water wells.

The fifth section deals with geologic history and is a synopsis of the geologic events described in the first four sections.

The appendix contains the sample analyses of 105 wells in the Tucson basin. 
THE INTERNAL STRUCTURE OF THE RINCON, TANQUE VERDE, AND SOUTHERN FORERANGE OF THE SANTA CATALINA MOUNTAINS

\section{Introduction}

This study of the internal structure of the Rincon, Tanque Verde, and southern forerange of the Santa Catalina Mountains is mainly a description of a series of large, parallel, west-southwest-trending, doubly plunging anticlines and synclines formed from the layered gneiss that comprises the ranges. These folds are significant to a study of the geology of the Tucson basin because of the control they have exerted upon the relief within the mountains, the position of the major drainages that enter the basin and the resulting pattern of erosion and deposition within the basin, the position of the frontal fault of the ranges, the position of normal faults within the basin, and the general outline or shape of the basin.

The descriptions that follow concerning the lithology, areal extent, foliation, age, and origin of the Catalina Gneiss are largely summaries of the works of others and are included here as background information. 


\section{Catalina Gneiss}

Definition, Areal Extent, and Lithology

The name "Catalina Gneiss" was first used in the literature by Blake (1908b, p. 379) in referring to the layered gneissic rocks of the south side of the Santa Catalina Mountains. The name currently is applied to all the rocks of the southern forerange and part of the main range of the Santa Catalina Mountains, as far north as Mount Lemmon, and to nearly the entire rock mass of Agua Caliente Hill and the Tanque Verde and Rincon Mountains (fig. 3).

The minerals in the gneiss consist dominantly of quartz, plagioclase, orthoclase, microcline, biotite, and muscovite. Epidote, garnet, zircon, staurolite, and tourmaline are present in minor amounts (DuBois, 1959b, p. 119-122).

Most workers recognize a transitional twofold subdivision of the Catalina Gneiss - the dominantly granitic rocks or granitic gneisses of the main range of the Catalinas and the banded or injection gneisses of the southern forerange of the Santa Catalina Mountains and the Tanque Verde and Rincon Mountains (Moore and others, 1941, p. 11; Bromfield, 1952, p. 53; Butler and others, 1952, p. 45). DuBois (1959a, p. 111) has modified this classification and recognizes three gradational types of gneissic rocks in the Catalinas-banded augen 


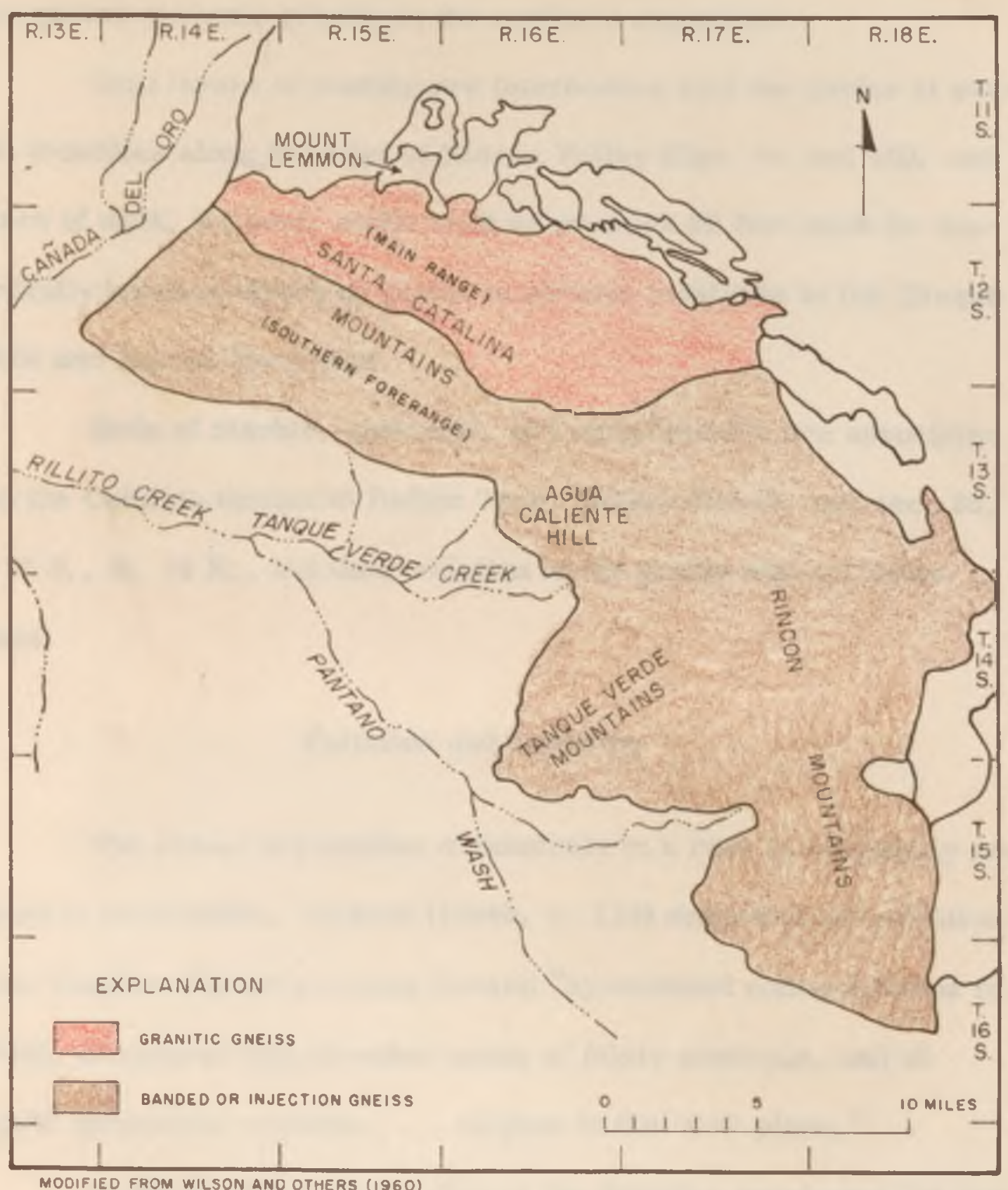

Figure 3. --Areal distribution of the Catalina Gneiss. 
gneiss in the southern part, augen gneiss in the central part, and granitic gneiss-gneissic granite in the northern exposures.

Thin layers of marble are interbedded with the gneiss at several localities along the edge of Rincon Valley (figs. 4A and 4B), and layers of dark, foliated, mafic rock as much as 20 feet thick lie concordantly between layers of gneiss at several localities in the Tanque Verde and Rincon Mountains.

Beds of marble, quartzite, and conglomerate are associated with the Catalina Gneiss at Italian Trap, Bellota Ranch, and sec. 35, T. 13 S., R. $16 \mathrm{E}$., but their relation to the gneiss was not determined.

\section{Foliation and Layering}

The planar orientation of minerals in a rock is commonly referred to as foliation. DuBois (1959b, p. 119) describes the foliation in the Catalina Gneiss as being formed "by oriented concentrations of biotite, of sheared and streaked zones of felsic minerals, and of aligned ellipsoidal crystals . . . aligned in the 'a-b' plane."

In the banded Catalina Gneiss the foliation penetrates the entire rock, but differences in the relative percentages of the component minerals result in a second feature parallel to the foliation and here referred to as layering. The layering of the gneiss is shown by the different resistance to erosion possessed by individual adjacent layers, 

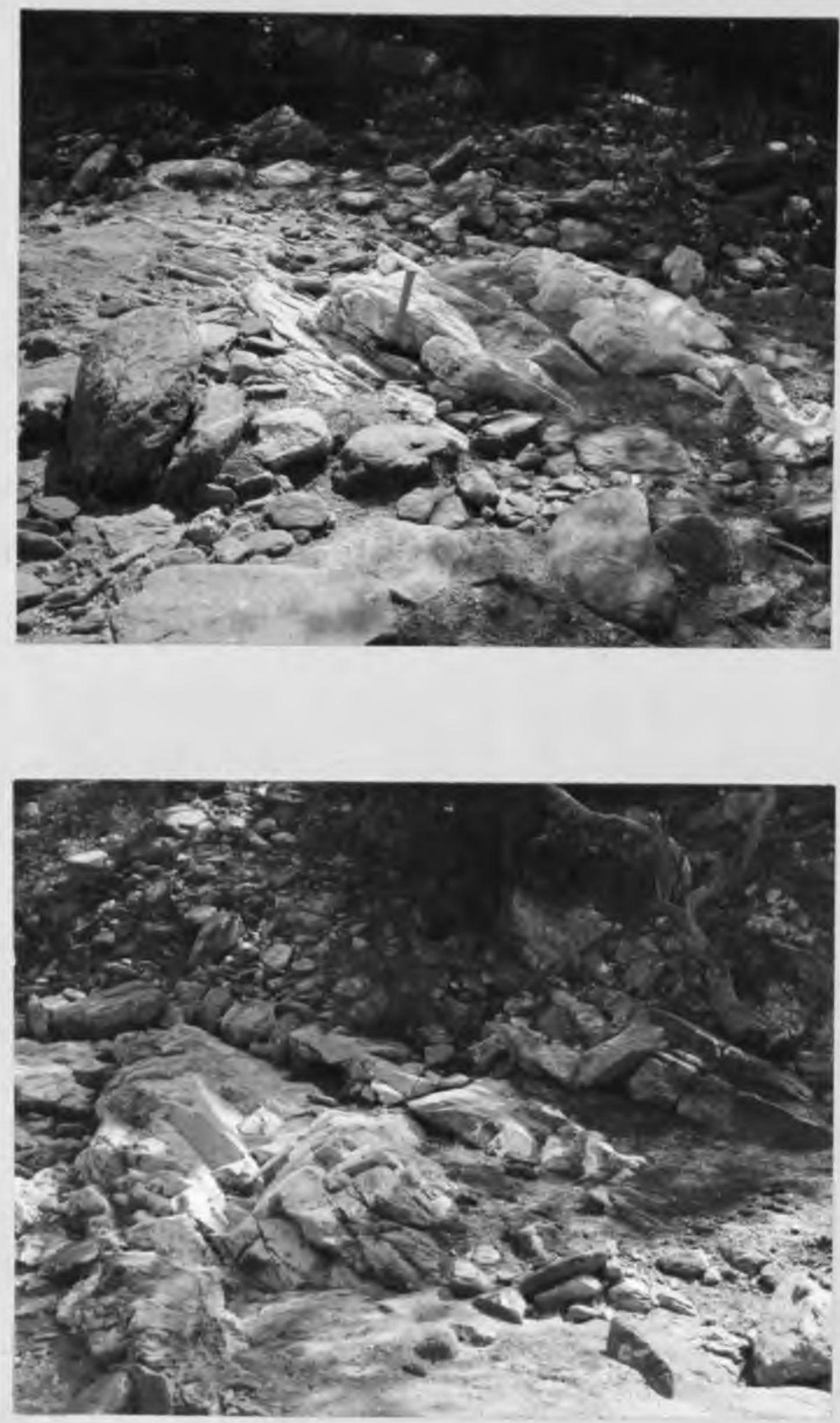
which results in a cliff-and-slope topography. Individual layers range in thickness from a few inches to a few tens of feet. The layering of the banded or injection phase of the Catalina Gneiss is one of its most noticeable properties and was first noted by Blake (1908b, p. 379-380), who commented: "The croppings appear like ordinary stratified sandstones and shales." He also noted "its tabular form, its regular stratification . . . its extreme foliation." The layering was utilized as if it were bedding in working out the internal structure of the ranges.

\section{Origin and Age}

Previous workers interpreted the Catalina Gneiss as being derived from sedimentary, volcanic, and intrusive rocks. Their views are summarized in table 1.

Dietrich (1960, p. 116) summarizes the literature on banded gneisses and concludes: "The banding of most banded gneisses probably reflects directly or reflects formation controlled by supracrustal stratification." He uses the term supracrustal to refer to all rock units deposited at the surface of the earth. It is preferable to "sedimentary" because it includes pyroclastic deposits and lava flows. My examination of the banded gneiss in outcrop and hand specimen revealed no possible relics of sedimentary structure other than the layering. Thin sections were cut from a finely laminated quartzose rock resembling quartzite and interbedded with the gneiss at 
TABLE 1

SUMMARY OF PREVIOUS WORK CONCERNING THE AGE OF METAMORPL:ISMI CF

IND THE ROCKS INVOLVED IN THE FORMATION OF THE CATALINA GNEISS

\begin{tabular}{|c|c|c|c|c|c|c|}
\hline REFERENCE & LOCATION & $\begin{array}{c}\text { IA TURE OF } \\
\text { ROCKS INVOLVED } \\
\end{array}$ & $\begin{array}{c}\text { AGE OF } \\
\text { ROCKS INVOLVED } \\
\end{array}$ & EVIDENCE FOR NATURE AND AGE & $\begin{array}{c}\text { AGE OF } \\
\text { METAMORPHISM }\end{array}$ & $\begin{array}{l}\text { EVIDENCE FOR AGE } \\
\text { OF METAMORPHISM }\end{array}$ \\
\hline $\begin{array}{l}\text { Blake (1908a, } \\
\text { p. } 47)\end{array}$ & $\begin{array}{l}\text { Southern Catalina } \\
\text { Mountains }\end{array}$ & & Precambrian & $\begin{array}{l}\text { Resemblance to Huronian, Kewee- } \\
\text { nawan, and Laurentian of Canada }\end{array}$ & Precambrian & Same as column 5 \\
\hline $\begin{array}{l}\text { Tolman (in Ran- } \\
\text { some, 1916.p.144) }\end{array}$ & Catalina Mountains & Granite & Post-Carboniferous & Intrusive and stratigraphic relations & $\begin{array}{l}\text { Post-Carbonifer- } \\
\text { ous }\end{array}$ & Same as column 5 \\
\hline $\begin{array}{l}\text { Hernon (1932, } \\
\text { p.1, 10, 15-18, } \\
25)\end{array}$ & $\begin{array}{l}\text { Rincon, Tanque } \\
\text { Verde, and south- } \\
\text { ern Catalina } \\
\text { Mountains } \\
\end{array}$ & $\begin{array}{l}\text { Shale, arkose, lime- } \\
\text { stone, igneous sills, } \\
\text { quartzite, lampro- } \\
\text { phyre }\end{array}$ & $\begin{array}{l}\text { (1) Cretaceous } \\
\text { (2) Pinal Schist } \\
\text { (3) Apache Group }\end{array}$ & $\begin{array}{l}\text { Modal analysis of gneiss. Believed } \\
\text { Cretaceous rocks graded into the } \\
\text { gneiss. }\end{array}$ & Post-Cretaceous(?) & $\begin{array}{l}\text { Eelieved Cretaceous } \\
\text { rocks graded into gneiss }\end{array}$ \\
\hline $\begin{array}{l}\text { Moore and } \\
\text { others (1941, } \\
\text { p. 12) }\end{array}$ & $\begin{array}{l}\text { Rincon, Tanque } \\
\text { Verde, and Cata- } \\
\text { lina Mountains }\end{array}$ & $\begin{array}{l}\text { Sedimentary forma- } \\
\text { tions }\end{array}$ & $\begin{array}{l}\text { Precambrian to } \\
\text { Cretaceous }\end{array}$ & $\begin{array}{l}\text { Cretaceous and older rocks grade } \\
\text { into gneiss }\end{array}$ & Post-Cretaceous & $\begin{array}{l}\text { Metamorphism involves } \\
\text { Cretaceous rocks }\end{array}$ \\
\hline $\begin{array}{l}\text { Peirce (1958, } \\
\text { p. 11, 79) }\end{array}$ & $\begin{array}{l}\text { Central Catalina } \\
\text { Mountains } \\
\end{array}$ & Granite & Older Precambrian & $\begin{array}{l}\text { Position of gneissic granite below } \\
\text { Scanlon Conglomerate }\end{array}$ & Laramide & Other workers \\
\hline $\begin{array}{l}\text { DuBois (1958. } \\
\text { p. } 15)\end{array}$ & Catalina Mountains & Sediments in part & $\begin{array}{l}\text { Precambrian } \\
\text { Apache Group }\end{array}$ & & & \\
\hline \multirow[t]{2}{*}{$\begin{array}{l}\text { DuBois (1959a, } \\
\text { p. 111) }\end{array}$} & $\begin{array}{l}\text { Southern Catalina } \\
\text { Mountains }\end{array}$ & $\begin{array}{l}\text { Sediments and } \\
\text { igneous rocks }\end{array}$ & & & \multirow[t]{2}{*}{ Post-Cretaceous } & \multirow{2}{*}{$\begin{array}{l}\text { Rocks that are intrusive } \\
\text { into Cretaceous sedi- } \\
\text { ments are metamor- } \\
\text { phosed }\end{array}$} \\
\hline & $\begin{array}{l}\text { Central Catalina } \\
\text { Mountains } \\
\end{array}$ & Granitic rocks & & & & \\
\hline $\begin{array}{l}\text { DuBois (1959b, } \\
\text { p. } 121-124)\end{array}$ & Catalina Mountains & $\begin{array}{l}\text { Igneous rocks and } \\
\text { argillaceous sedi- } \\
\text { ments }\end{array}$ & & $\begin{array}{l}\text { High percentage of quartz and pres- } \\
\text { ence of rounded zircons }\end{array}$ & Post-Cretaceous & \\
\hline $\begin{array}{l}\text { Laughlin (1959, } \\
\text { p. } 51-52)\end{array}$ & \begin{tabular}{|l|} 
Molino basin of \\
Catalina Mlountains \\
\end{tabular} & Sediments & & $\begin{array}{l}\text { Anhedral zircons, sphene, and high } \\
\text { percentage of guartz }\end{array}$ & & \\
\hline $\begin{array}{l}\text { Pilkington (1962, } \\
\text { p. } 12,91-93)\end{array}$ & $\begin{array}{l}\text { Northeastern Cata- } \\
\text { lina Mountains }\end{array}$ & $\begin{array}{l}\text { Igneous rocks, meta- } \\
\text { sediments, and sedi- } \\
\text { ments }\end{array}$ & Precambrian & $\begin{array}{l}\text { Involves Pinal Schist and Pioneer } \\
\text { Formation }\end{array}$ & $\begin{array}{l}\text { Post-Paleozoic } \\
\text { and pre-upper } \\
\text { Miocene }\end{array}$ & Other workers \\
\hline $\begin{array}{l}\text { Damon and } \\
\text { others }(1963 \text {, } \\
\text { p. } 116-118)\end{array}$ & $\begin{array}{l}\text { Catalina and } \\
\text { Rincon Mountains }\end{array}$ & & & & $\begin{array}{l}24.8-29.5 \mathrm{~m} . \mathrm{y} \\
\text { Terminated by } \\
\text { upper Oligocene- } \\
\text { lower Miocene time }\end{array}$ & $\begin{array}{l}\text { K-Ar age determinations } \\
\text { of mica from gneiss }\end{array}$ \\
\hline
\end{tabular}


many places along the front of the Catalinas. These sections were examined by H. W. Peirce and R. L. DuBois, who have informed the author that the finely laminated structure represents planes of internal movement rather than sedimentary bedding planes. This, however, does not rule out the possibility that movement took place parallel to bedding planes and in doing so destroyed evidence for their existence. Rounded zircons and the high quartz content in these thin sections suggest a sedimentary origin for the rock.

The layers of marble interbedded with the gneiss in Rincon Valley may be interpreted as remnants of limestone beds that survived the metamorphism, which converted the enclosing sediments to gneiss. The mafic layers in the Rincon and Tanque Verde Mountains probably represent flows or sills interbedded with a series of bedded sediments and metamorphosed with them.

All but the very first workers who speculated on the age of the metamorphism recognized, on the basis of stratigraphic and intrusive relations, its relatively young age. Their opinions on this subject are summarized in table 1. This table also includes the age or name of the different formations thought to be involved in the metamorphism and converted into gneiss.

Potassium-argon age determinations of micas from the gneiss of the Santa Catalina and Rincon Mountains indicate apparent ages that range between 24.8 and 29.5 m. y. Damon and others (1963, p. 116, 
118) interpret these ages as indicating "that uplift had progressed to the point that metamorphism had terminated by Upper Oligocene-Lower Miocene time."

\section{Folds in the Catalina Gneiss}

Previous Work

Broad anticlines and synclines present in the Catalina Gneiss have been described by several previous workers (table 2). Examination of this table reveals that folds with west-northwest-trending axes are described by Hernon (1932), Moore (written communication, 1940), Bromfield (1952), and Pilkington (1962). Other workers-Peirce (1958), Laughlin (1959), Wilson (1962), and Peterson (1963) - all mention more than one trend for the folds, including west-northwest and northeast. DuBois (1959a) favors an east-northeast to east trend. Peterson and Mayo (oral communication, 1963) both recognize eastnortheast folds that have been cross folded along west-northwest axes.

Method of Investigation and Interpretation

In determining the structure of the gneiss, the attitudes of the gneiss layers were measured and plotted on the base map (p1. 1). In addition, the trend and plunge of a prominent lineation, which lies in the plane of the layering, were also measured, plotted, and used in 
TABLE 2

SUMMARY OF PREVIOUS WORK CONCERMNG FOLDS IN THE CATALINA, TANQUE VERDE, AND RINCON MOUNTAINS

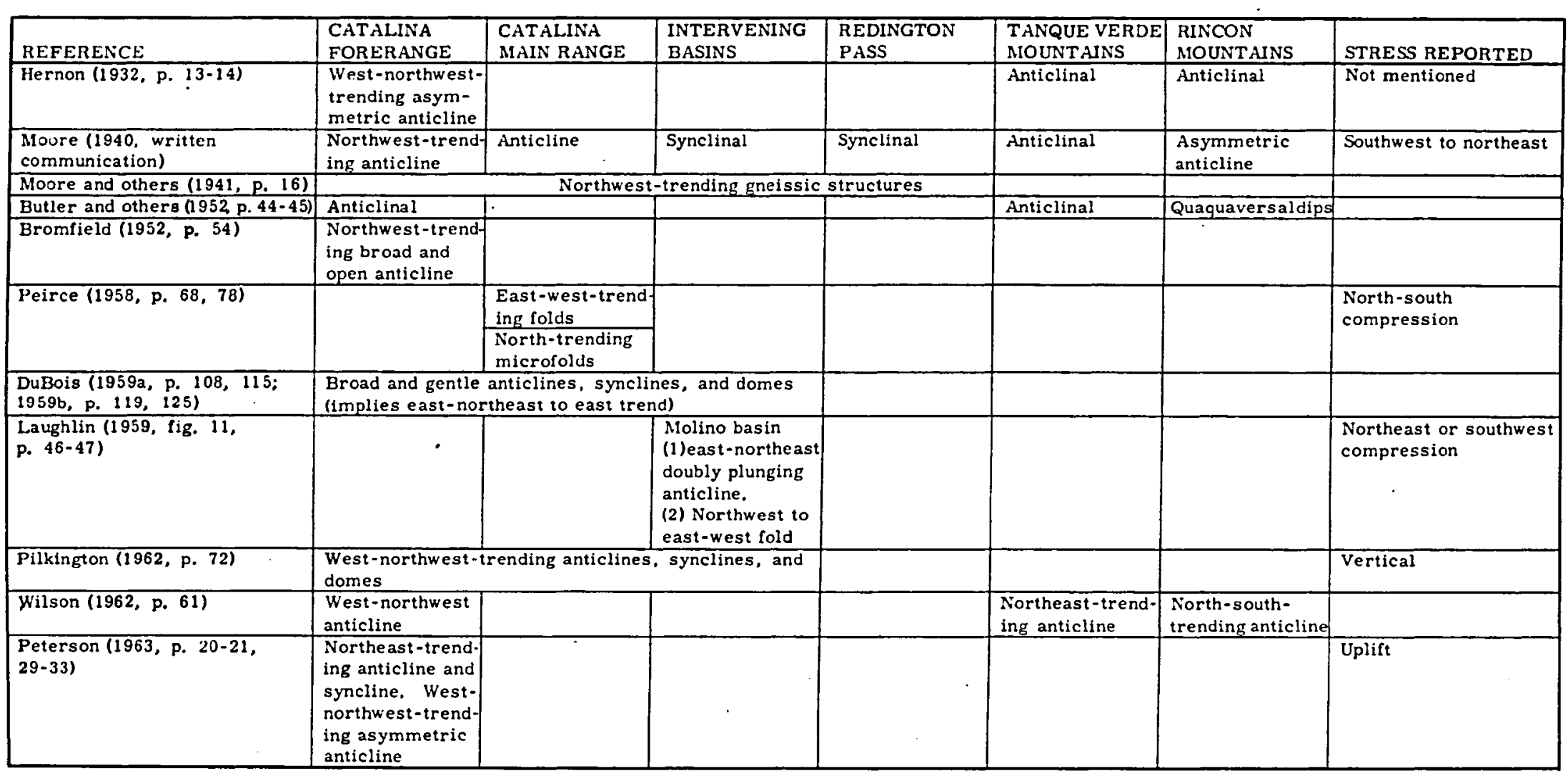


interpreting the diverse attitudes of the layers. Measurements of layering and lineation from the map of Moore and others (1941) were transposed onto plate 1 to fill in areas that were not visited during this study. From these measurements the positions of individual folds were worked out using the principles discussed below.

$$
\text { Billings (1942, p. 233) summarizes the use of lineation in }
$$

working out the structure of metamorphic rocks as follows:

The secondary lineation so characteristic of metamorphic rocks is an aid in solving major structure. In many localities lineation is parallel to the axes of folds ... The use of lineation in the field is comparatively simple. If the lineation is horizontal, the axes of the fold are horizontal; if the lineation plunges $35^{\circ}$ northwest, the folds must plunge $35^{\circ}$ northwest.

Lineation that parallels fold axes is formed during folding as grains are oriented, recrystallized, and elongated at right angles to the direction of movement (parallel to the axis of folding). Lineation is also an indication of stress direction. To quote Cloos (1946, p. 2): ". . . folds and wrinkles are thought to indicate a direction normal to movement, and almost all geologists also assume the direction of compression to be perpendicular to the trends of folds or fold axes. " Lineation is, however, not always parallel to fold axes, and before assuming that it is, some valid reason must be given.

In the Santa Catalina, Tanque Verde, and Rincon Mountains the attitudes of the layers indicate that they are folded, but most of the folds are so broad that it is impossible to determine the trend of their axes 
from a few scattered foliation measurements alone. Locally, however, some of the folds are small, having amplitudes of 10 to 30 feet, so that the geometry of the fold may be studied and worked out in a single exposure. Where this has been done and the trend and plunge of their axes or hinge lines have been determined accurately, the axes of the folds are parallel in trend and plunge to the lineation developed on their limbs. This appears to be confirming evidence that the lineation in the gneiss is parallel to the axis of folds and can be utilized in working out the geometry of the folds in the gneiss and in determining the position of individual foliation measurements with respect to the axes of major plunging anticlines and synclines.

The prominent lineation in the gneiss of the southern forerange of the Santa Catalina Mountains and in the Tanque Verde and Rincon Mountains (fig. 5) has a fairly constant east-northeast trend throughout these ranges and plunges to the east-northeast or west-southwest. Locally, variations in the trend are present.

DuBois $(1959 \mathrm{~b}, \mathrm{p}, 119,121)$ describes the lineation as "shown by the orientation of ellipsoidal grains and by the distribution of micaceous minerals and... strings of mica crystals alternating with strings of feldspar crystals." This orientation of grains and strings of crystals gives the gneiss its characteristic streaked appearance.

The lineation was noticed by most earlier workers. Their comments on its origin and significance are summarized in table 3. 

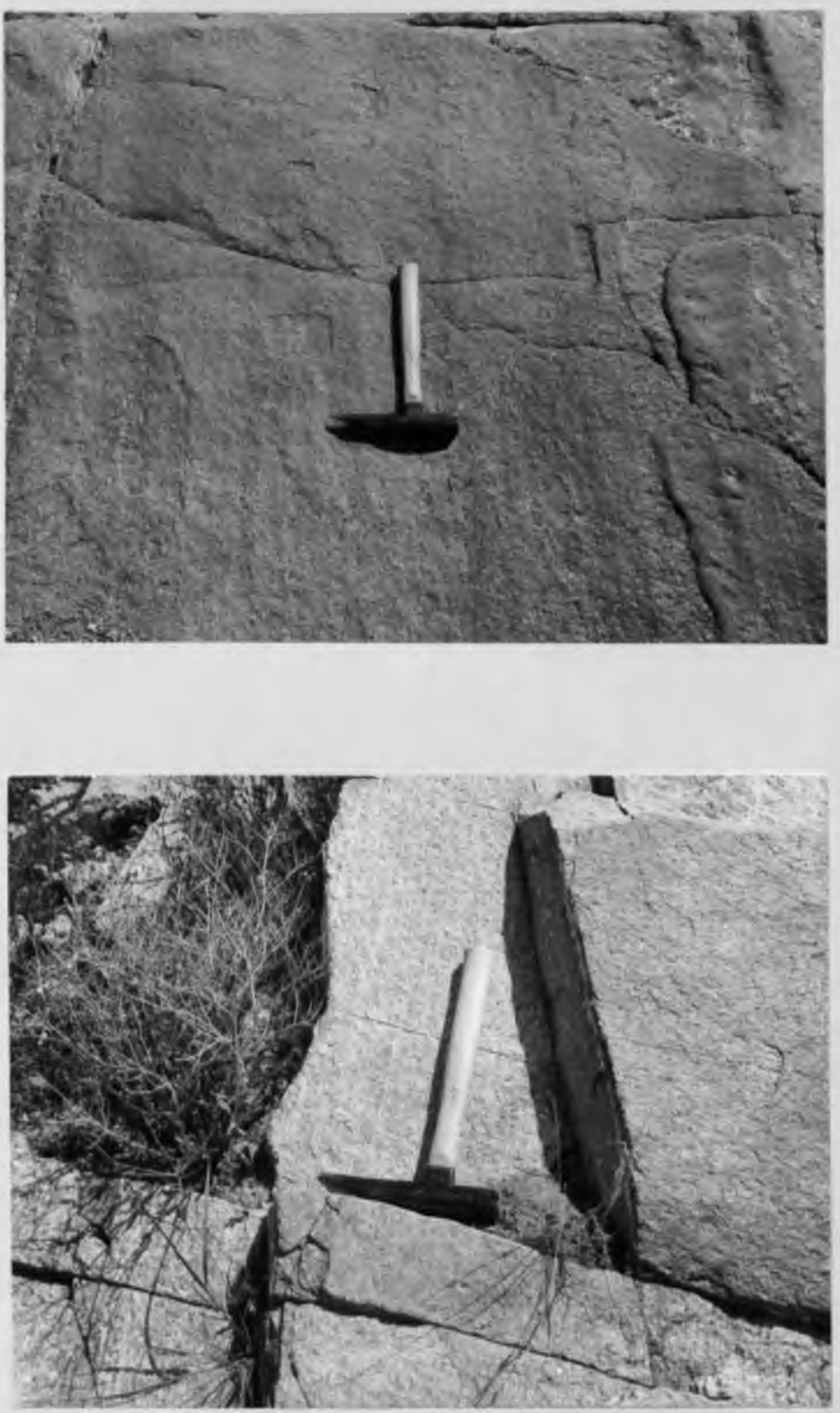
TABLE 3

SUMMARY OF PREVIOUS WORK CONCERNING THE LINEATION IN THE CATALINA GNEISS

\begin{tabular}{|c|c|c|c|c|c|}
\hline REFERENCE & NATURE OF THE LINEATION & TREND & $\begin{array}{l}\text { RELATION TO } \\
\text { FOLD AXES }\end{array}$ & ORIGIN & AREA \\
\hline Blake $(1908 \mathrm{~b})$ & $\begin{array}{l}\text { Elongation of nodules of feldspar: rolled sheets } \\
\text { of quartz }\end{array}$ & & & $\begin{array}{l}\text { Elongation by stretching } \\
\text { under pressure }\end{array}$ & $\begin{array}{l}\text { Southern Catalina } \\
\text { Mountains }\end{array}$ \\
\hline $\begin{array}{l}\text { Moore (written communication, } \\
\text { 1940) }\end{array}$ & "Striae or stretch marks" & Northeast & Right angle & $\begin{array}{l}\text { Shearing, large regional } \\
\text { forces from northeast to } \\
\text { southwest }\end{array}$ & $\begin{array}{l}\text { Catalina, Rincon, } \\
\text { Tanque Verde } \\
\text { Mountains } \\
\end{array}$ \\
\hline \multirow[t]{4}{*}{ Peirce $(1958$, p. 71,77$)$} & $\begin{array}{l}\text { In metasediments: stretched pebbles and } \\
\text { minerals }\end{array}$ & Northeast & & & \multirow[t]{4}{*}{$\begin{array}{l}\text { Central Catalina } \\
\text { Mountains }\end{array}$} \\
\hline & In Pioneer Formation: fold axes & Northerly & Right angle & & \\
\hline & $\begin{array}{l}\text { In Precambrian and Paleozoic metasediments: } \\
\text { drag folds }\end{array}$ & East-west & Parallel & North-south compression & \\
\hline & In granite gneiss: stretched mica and quartz & $\begin{array}{l}\text { Northeast, locally } \\
\text { more easterly }\end{array}$ & Oblique & Cataclastic action & \\
\hline \multirow[t]{2}{*}{ DuBois (1958, 1959a, 1959b) } & $\begin{array}{l}\text { Older lineation in gneiss: oriented mica and } \\
\text { feldspar. }\end{array}$ & East-west & & & \multirow[t]{2}{*}{$\begin{array}{l}\text { Catalina Moun- } \\
\text { tains }\end{array}$} \\
\hline & $\begin{array}{l}\text { Younger lineation in gneiss: Oriented minerals } \\
\text { and strings of minerals }\end{array}$ & $\begin{array}{l}\text { Northeast becoming } \\
\text { east-west } \\
\end{array}$ & "b" lineation & Cataclastic action & \\
\hline \multirow[t]{2}{*}{ Laughlin (1959, p. 42, 47) } & (1) Alignment of mica and feldspar & N. $40^{\circ}-60^{\circ} \mathrm{E}$ & "a"lineation & \multirow{2}{*}{$\begin{array}{l}\text { Northeast or southwest } \\
\text { compression }\end{array}$} & \multirow[t]{2}{*}{ Molino basin } \\
\hline & (2) Same & N. $40^{\circ}-60^{\circ} \bar{E}$. & "b"lineation & & \\
\hline \multirow[t]{3}{*}{$\begin{array}{l}\text { Pilkington.(1962, p. 12, 81-83, } \\
88,113)\end{array}$} & $\begin{array}{l}\text { Elongated feldspar and quartz. Stretched } \\
\text { masses of mica }\end{array}$ & N. $20^{\circ}-45^{\circ} \mathrm{E}$. & "a"lineation & Cataclastic deformation & $\begin{array}{l}\text { Southwest flank of } \\
\text { Catalina Mountains }\end{array}$ \\
\hline & $\begin{array}{l}\text { Parallel folds, oriented crystals and pebbles, } \\
\text { intersection of S-planes, stretched mica }\end{array}$ & $\begin{array}{l}\text { West-northwest to } \\
\text { west }\end{array}$ & "b" lineation & Vertical forces & \multirow{2}{*}{$\begin{array}{l}\text { Northeast flank } \\
\text { of Catalina } \\
\text { Mountains }\end{array}$} \\
\hline & $\begin{array}{l}\text { Elongation of minerals, streaking of mica, } \\
\text { slickensides in gneiss }\end{array}$ & $\begin{array}{l}\text { N. } 30^{\circ} \mathrm{W} . \text { and } \\
\text { north-northeast }\end{array}$ & "a"lineation & Vertical forces & \\
\hline Peterson (1963, p. 19, 31) & $\begin{array}{l}\text { Elongated quartz grains and feldspar; streaking } \\
\text { of mica; oriented metasedimentary inclusions; } \\
\text { fold axes }\end{array}$ & N. $50^{\circ}-70^{\circ} \mathrm{E}$ & "b" lineation & $\begin{array}{l}\text { Folds and stretching of } \\
\text { minerals by uplift }\end{array}$ & $\begin{array}{l}\text { Sabino Canyon } \\
\text { area }\end{array}$ \\
\hline
\end{tabular}


For a different interpretation of the origin and significance of the lineation in the Catalina Gneiss, the reader is referred to a paper by E. B. Mayo soon to be published in volume VII of the Arizona Geological Society Digest.

\section{Pusch Ridge Anticline}

The large anticline exposed in cross section in the cliffs and spurs of the northwest face of Pusch Ridge is one of the most striking structural features of the Santa Catalina Mountains. It is the fold described by Hernon (1932, p. 13) as an "asymmetrical anticline whose axis strikes WNW." Bromfield (1952, p. 54) describes it as "an asymmetrical anticline with a gentle south limb and a steeply dipping to overturned north limb."

The author interprets the foliation and lineation measurements made in the Pusch Ridge area (pl. 1) as delineating a doubly plunging anticline whose axis trends approximately. N. $65^{\circ} \mathrm{E}$. The point of reversal of plunge of the axis appears to be in or near the $\mathrm{NW}-1 / 4 \mathrm{sec}$. 16, T. 12 S. , R. 14 E. Dip measurements made on the northwest limb range between $26^{\circ}$ and $80^{\circ}$. Dip measurements on the southeast limb range between $19^{\circ}$ and $50^{\circ}$.

Erosional retreat of the mountain front has removed nearly all the rocks of the northwest limb from the mountain face south of Alamo Canyon, but remnants of it can be seen forming. the lower spurs 
of the mountain front north of Alamo Canyon. The upper cliffs of Pusch Ridge, because they have retreated by erosion to a position southeast of the fold axis, are formed entirely from the rocks of the southeast limb of the anticline. Figures $6 \mathrm{~A}$ and $6 \mathrm{~B}$ show two views of this fold. The photos were taken looking nearly parallel to and obliquely to the axis, respectively.

Folds Between Pusch Ridge and Sabino Canyon

Several folds were observed in the interval between Pusch Ridge and Sabino Canyon, but, because of insufficient foliation and lineation measurements, they were not plotted on plate 1. Foliation measurements in Alamo Canyon in the southeast corner of sec. 10, T. 12 S., R. 14 E., indicate a syncline plunging east-northeast parallel to the Pusch Ridge anticline.

A major anticline is revealed by a gentle arching of the gneiss layers on the wall of Pima Canyon (fig. 7). This fold lies southeast of the Pusch Ridge anticline.

A small anticline, with an amplitude of only a few tens of feet, is exposed in the NW-1/4SW-1/4 sec. $33, T .12 \mathrm{~S} .$, R. $14 \mathrm{E}$. The fold axis, as determined by tracing of layers, is proved to be parallel to the lineation developed on its limbs. The axis of this fold trends eastnortheast and plunges to the west-southwest. 


\section{FIGURE 6}

PUSCH RIDGE ANTICLINE

A.

The Pusch Ridge anticline as seen looking nearly parallel to the axis. Photo by Tad Nichols.

B.

The Pusch Ridge anticline viewed looking normal to Pusch Ridge. The apparent dips of the layers of Catalina Gneiss suggest a steeply dipping to overturned north limb of an anticline. Alamo Canyon is to the right of center. Photo by Tad Nichols. 

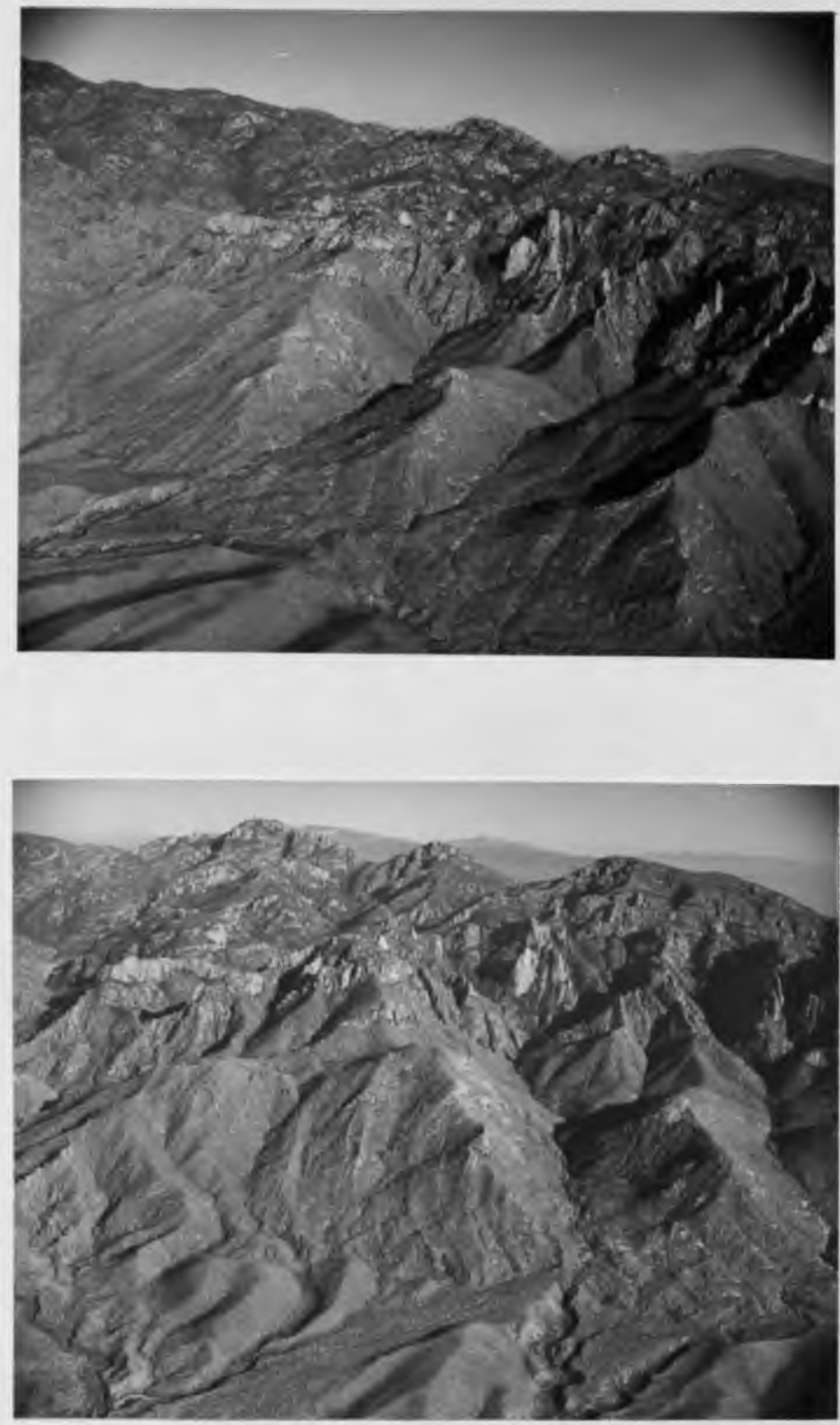


\section{FIGURE 7}

ANTICLINAL FOLD, PIMA CANYON

Looking northeast at an anticlinal fold exposed in cross section on the wall of Pima Canyon. Photo by Tad Nichols. 


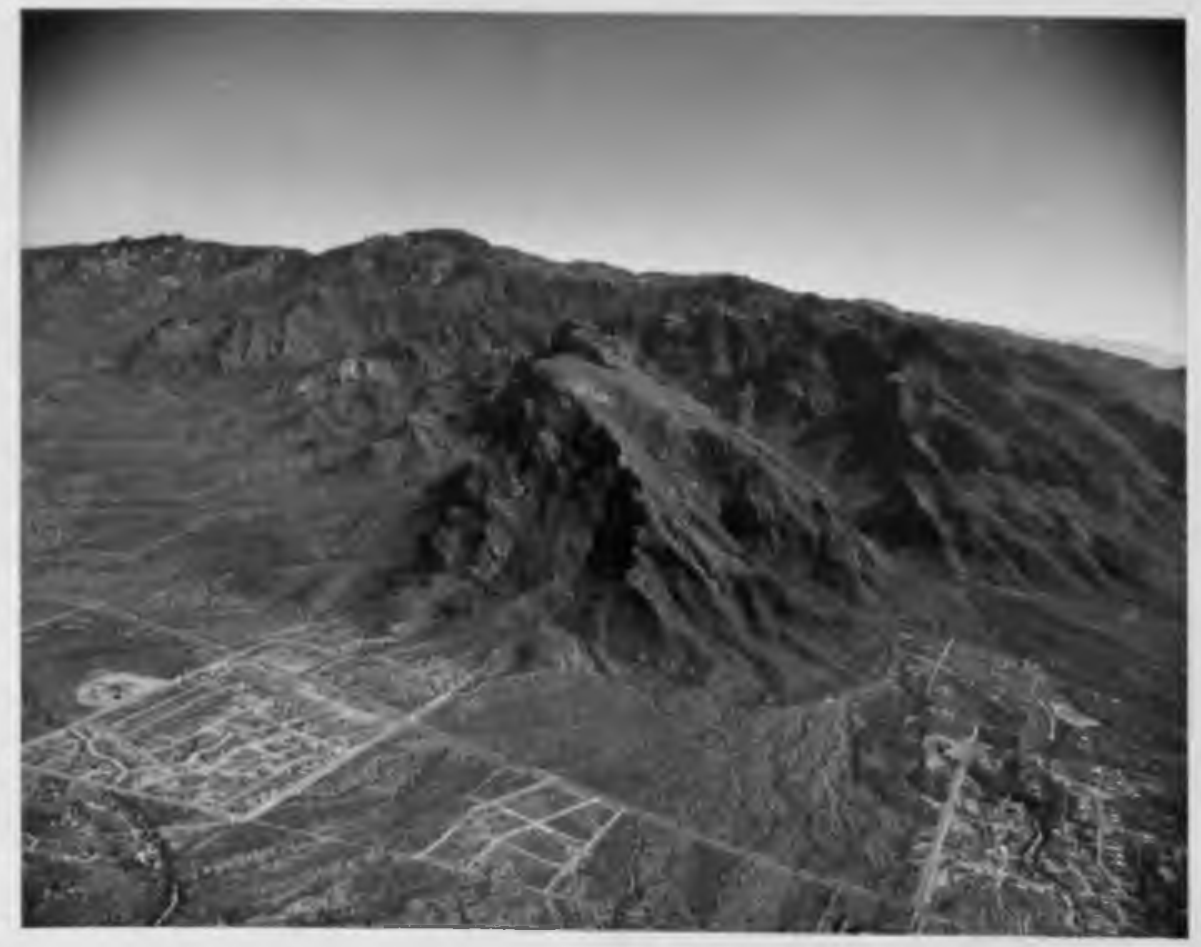


Additional folds are present between Pima and Sabino Canyons, but no attempt was made to obtain the measurements necessary to delineate their axes.

\section{Sabino-Bear Canyon Anticline}

An anticline exposed in cross section on the southeast wall of Sabino Canyon (fig. 8A) is the fold described by Bromfield (1952, p. 54) as an anticline with a northwesterly trending axis. More recently, Peterson (1963, p. 20-21) described it as a very gentle fold which has an axis that trends $\mathrm{N} 60^{\circ} \mathrm{E}$. , plunges $10^{\circ} \mathrm{SW}$, , and is bounded on the northeast by a cross fold that trends west-northwest.

The present author's interpretation varies somewhat from both of the above descriptions. The foliation and lineation measurements shown on plate 1 in the Sabino-Bear Canyon region are here interpreted as delineating a broad doubly plunging anticline that trends approximately N. $70^{\circ} \mathrm{E}$. (pl. 1). An accurate location of the axis is complicated by subsidiary folds on the limbs of the main fold and by the lack of sufficient field measurements.

The point of reversal of plunge of the axis appears to be located at Seven Falls in Bear Canyon. From Seven Falls the axis plunges west-southwest, reaching a maximum angle of plunge of about $20^{\circ}$, and east-northeast at what appears to be an even steeper angle. 


\title{
FIGURE 8
}

\section{SABINO AND BEAR CANYONS}

(Pholos by 'lad Nichols)

\begin{abstract}
$\Lambda$.
Looking cast at warped layers of gnelss formlng the crest of the southeast wall of Sablno Canyon.
\end{abstract}

B.

Looking northeast up Into Snbino and Bear Canyons. View is looking parallel to the trend of the Sabino-Bear Canyon anticline. 

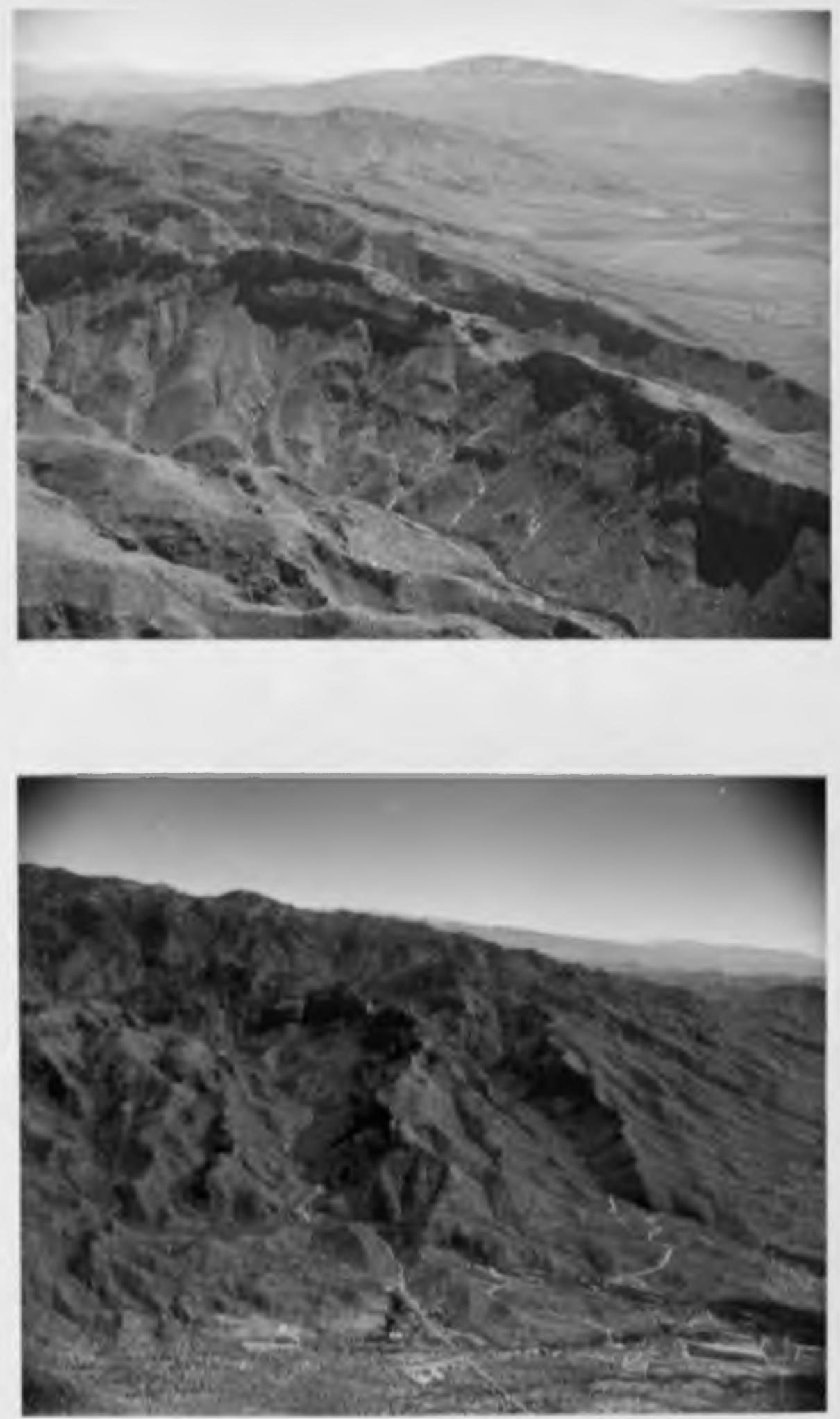
Attitude determinations on the northwest limb of the fold indicate that it dips to the northwest at angles that range between $20^{\circ}$ and $50^{\circ}$.

The southeastern limb of this anticline, as exposed along the south base of the range between the mouths of Molino and Bear Canyons, strikes N. $86^{\circ} \mathrm{W}$, parallel to the trend of the mountain front, and dips to the south at angles of from $25^{\circ}$ to $45^{\circ}$. Along this stretch the southern front of the range is essentially a dip slope on the southcast limb of the fold (fig. 8A). Between the mouth of Bear Canyon and the spot where the Sabino Canyon road enters the mountain, the gneiss layers bend around on the nose of this west-southwest-plunging anticline (fig. 8B). This bending of the gneiss on the nose of the fold likewise is reflected in the trend of the mountain front, which also bends parallel to the trend in the gneiss.

Figure $8 \mathrm{~A}$ is a view of this fold exposed in cross section in the southeast wall of Sabino Canyon. The backbone of the ridge shown trends about N. $55^{\circ} \mathrm{E} . ;$ whereas, the axis of the anticline trends about N. $70^{\circ} \mathrm{E} .$, a difference in trend of only $15^{\circ}$. Thus, the photograph reveals a cross section that is nearly parallel to the axis of the fold. The warping of the beds shown, according to this author's interpretation, reflects the doubly plunging nature of the axis rather than the dip of the limbs, which is in directions away from the axis. The author believes that this is the cross section of the fold that Bromfield observed in 
describing it as "an anticline with a northwesterly trending axis" and which Peterson interprets as a cross fold that trends west-northwest.

\section{Molino Canyon Anticline}

The fold shown on plate 1 as the Molino Canyon anticline is probably a southwestern extension of an anticline described by Laughlin (1059, fig. 11). The present author interprets it as being a doubly plunging anticline trending east-northeast. The point of reversal of plunge is located cast of the Mount Lemmon Highway; from this point it plunges to the southwest and northeast. The fold dies out to the southwest where it merges with the southeast limb of the Sabino-Bear Canyon anticline. The dips of the limbs range from $17^{\circ}$ to $25^{\circ}$.

\section{La Mulagrosa Syncline}

The trough of the doubly plunging La Milagrosa syncline lies along the cast-northeast-trending topographic axis of the saddle between the Santa Catalina Mountains and Agua Caliente Hill (pl. 1; fig. 9A). The northwest and southeast slopes of the saddle are dip slopes formed by the limbs of the syncline. The northwest limb dips south at angles ranging from $9^{\circ}$ to $26^{\circ}$. The southeast limb dips north at angles ranging from $13^{\circ}$ to $36^{\circ}$. The axis of the syncline trends cast-northeast and plunges to the west-southwest at an angle of about $10^{\circ}$ and to the castnortheast at an undetermined angle. The point of reversal of plunge is 


\title{
FIGURE 0
}

FOLDS IN TIIE 'TANQUE VERDE MOUN'TINS-

AGUA CALIENTE IILL REGION

(Photo for Ligure OA by Jay Dusard)

\begin{abstract}
$\Lambda$.
Looking cast-northeast up into the saddle between the Santa Catalina Mountains and Agua Caliente 1111. The slopes of the saddle are dip slopes on the limbs of the La Milagrosn syncline.
\end{abstract}

B.

Looking southeast at the west-southwest-plunglng 'Inngue Verde Mountains. 

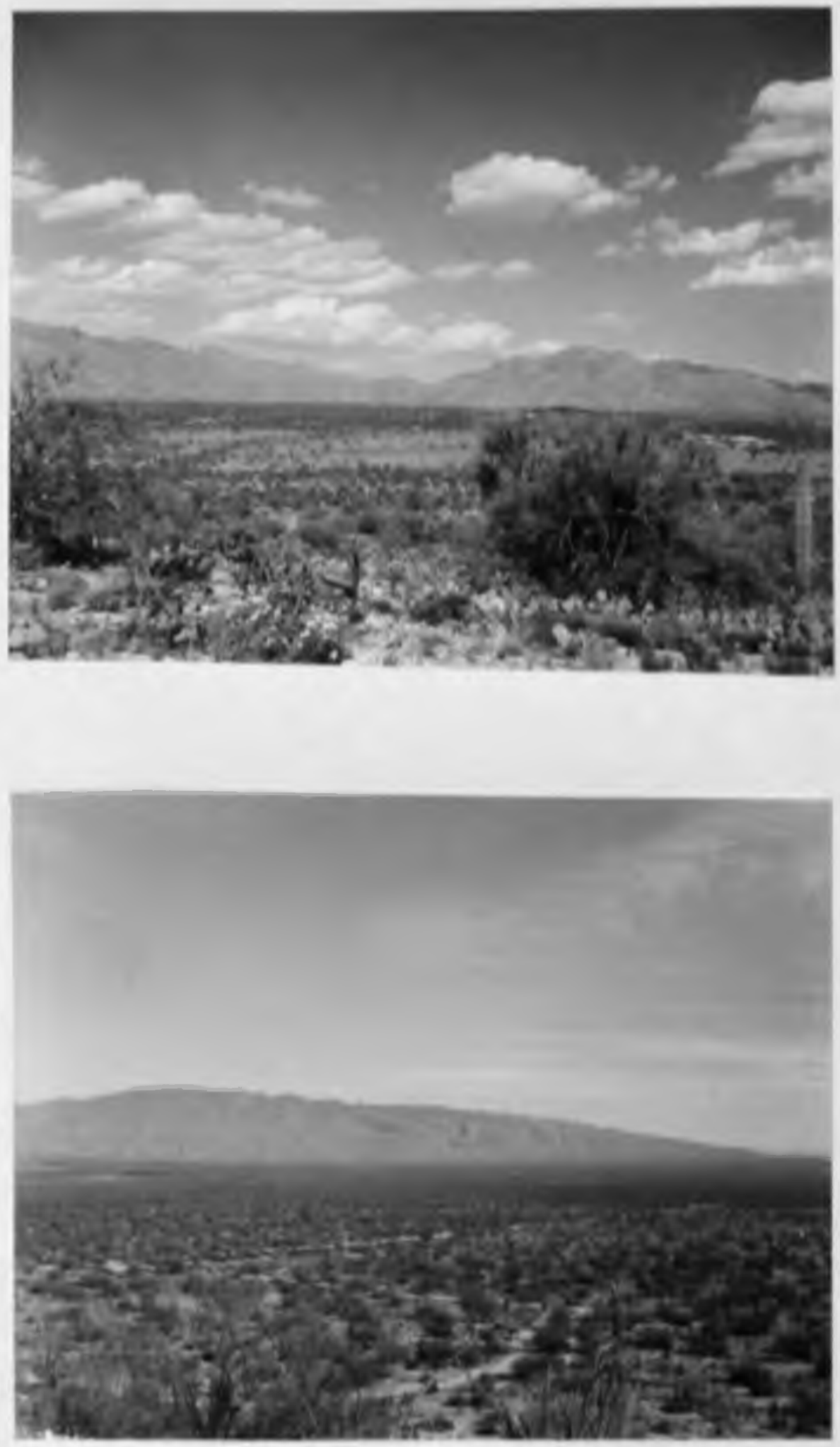
located about 2 miles east-northeast of the mouth of Molino Canyon. The configuration of this west-southwestward-plunging syncline is reflected by the recntrant in the mountain base line between Agua Caliente Hill and the Santa Catalina Mountains, which trends with the strike of the layers as they bend around the plunging axis of this fold.

Folds in the Agua Caliente Hill-Tanque Verde Canyon Area

It was anticipated that Agua Caliente Hill might lie along the axis of an anticline and that the pass between Agua Caliente Hill and the Tanque Verde Mountains would follow the axis of a syncline. Reconnaissance mapping did not disclose these suspected structures. The lineation in the area maintains the same east-northeast trend observed in the adjacent mountains and indicates that the axis of folding is the same as in the Santa Catalina and Tanque Verde Mountains. Foliation and lineation are poorly developed in this area and make reconnaissance mapping difficult.

\section{Tanque Verde Anticline}

The Tanque Verde Mountains are formed by a doubly plunging symmetrical anticline whose axis coincides approximately with the eastnortheast-trending backbone of the Tanque Verde and Rincon Mountains (fig. OB). The axis plunges to the west-southwest at angles of $15^{\circ}$ to 
$20^{\circ}$ and to the cast-northeast at an undetermined angle. The point of reversal of plunge is located north of Spud Rock. The limbs dip to the northwest and southeast at angles ranging between $15^{\circ}$ to $35^{\circ}$.

Follation measurements and observations on the lower slopes of the mountains indicate the presence of parallel subsidiary folds on the llanks of the main fold and account for attitudes that appear to be discordant to the limbs of the main fold. Lincation measurements of these subsidiary folds indicate that they also are doubly plunging.

\section{Rincon Valley Syncline}

The axis of a major west-southwest-trending and plunging syncline colncides with the topographic axis of Rincon Valley (pl. 1). The northwest limb is formed by the southeasterly dipping rocks of the southeast slope of the Tanque Verde Mountains (the southeast limb of the Tanque Verde anticline). The southeast limb is formed by the northwest-dipping rocks of the southern ridge of the Rincon Mountains. The trough of the syncline lies burled beneath the younger rocks of Rincon Valley. The axis appears to reverse its plunge near the Happy Valley sadulc.

Folds in the Southern Rincon Mountains

Follation measurements are too few and too scattered in the southern Rincon Mountains to delineate the trend of individual folds. 
The lincation in this arca maintains its usual cast-northeast trend; on this basis it Is suggested that the southern ridge of the Rincon Mountains is an cast-northeast-trending anticline with many parallel subsidiary folds on its flanks.

Reflection of the Folds in the Physiography

Previous Work

Previous workers have discounted or not considered the effect of the Internal structure of the Santa Catalina, Tanque Verde, and Rincon Mountains upon the topographic configuration of the mountains.

One of the classic concepts of basin-range structure is that the internal structure of the basin ranges is transected by their border faults, along which the ranges have been uplifted with respect to the basins. Therefore, the typically straight fronts of basin ranges reflect the positions of normal faults rather than their internal structure.

This concept was used by Davis (1931, p. 290-291) when he described the Santa Catalina Mountains as follows:

. . . an upllfted and dissected two-fault block, chiefly because thele southern and western sides have rather simple base lines which transect the rock structures indifferently. The generallzed southern base is fairly straight, cxcept for a southward jog of about a mile, perhaps due to a subordinate fault, as it approaches the Tanque Verde mass.

Simllar reasoning whs used in the report that prefaced the present study 
(The Rillito Creck Hydrologic Research Committee, 1959, p. 38): "The boundary faults trend approximately north-south and east-west . . . The angulate pattern of the boundary faults, and the fact that the Pantano beds arc locally tilted, fractured, and faulted, indicate that some of the boundary faults may extend into the basin." Thus, the Catalinas were pictured as being uplifted along a series of east-west-trending border faults that were in turn offset by a series of north-south-trending transverse faults, which together would explain the configuration of the fronts of the ranges. Figure 10 is a generalized summary of this type of interpretation.

\section{Revised Interpretation}

Figure 11 is a generallzed diagram of the folds in the Rincon, Tanque Verde, and southern Santa Catalina Mountains and reveals the close relationship that exists between the folds and the physiography of the ranges. Topographic highs, like the Tanque Verde and Rincon Mountains, lic along structural highs, which are the axes of anticlines. Topographle lows, such as Rincon Valley, the pass between the Catalinas and Agua Caliente H111, and perhaps between Agua Caliente Hill and the Tanque Verde Mountains, lie along structural lows, which are the axes of plunging synclines. Major drainages enter the basin along the axes of these synclines. 


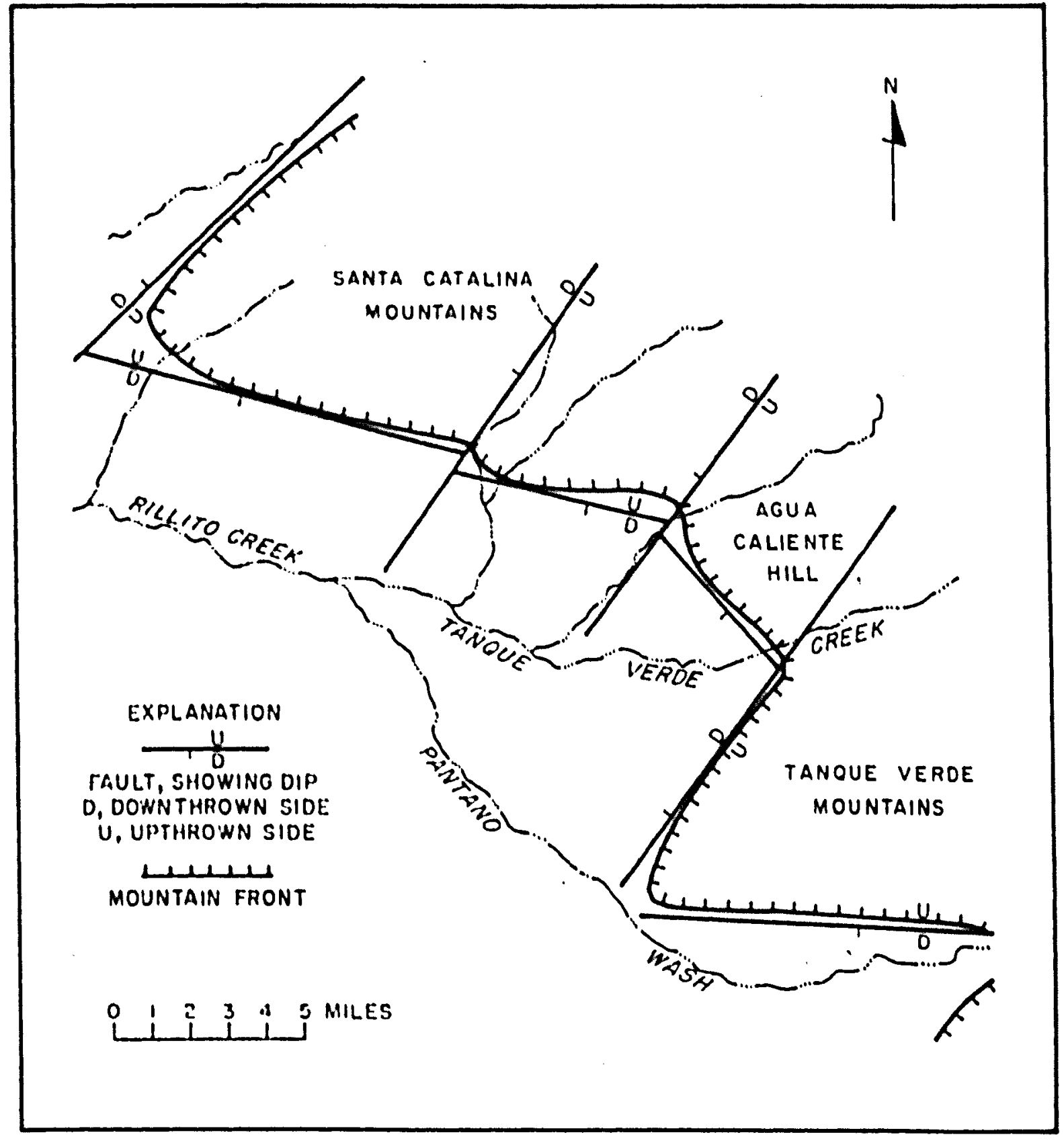

Pigfure 10, - Fencralized malp showing border faults offset by transeresse fault: ats an explatnation for the configuration of the rroutsi of the ringes. 


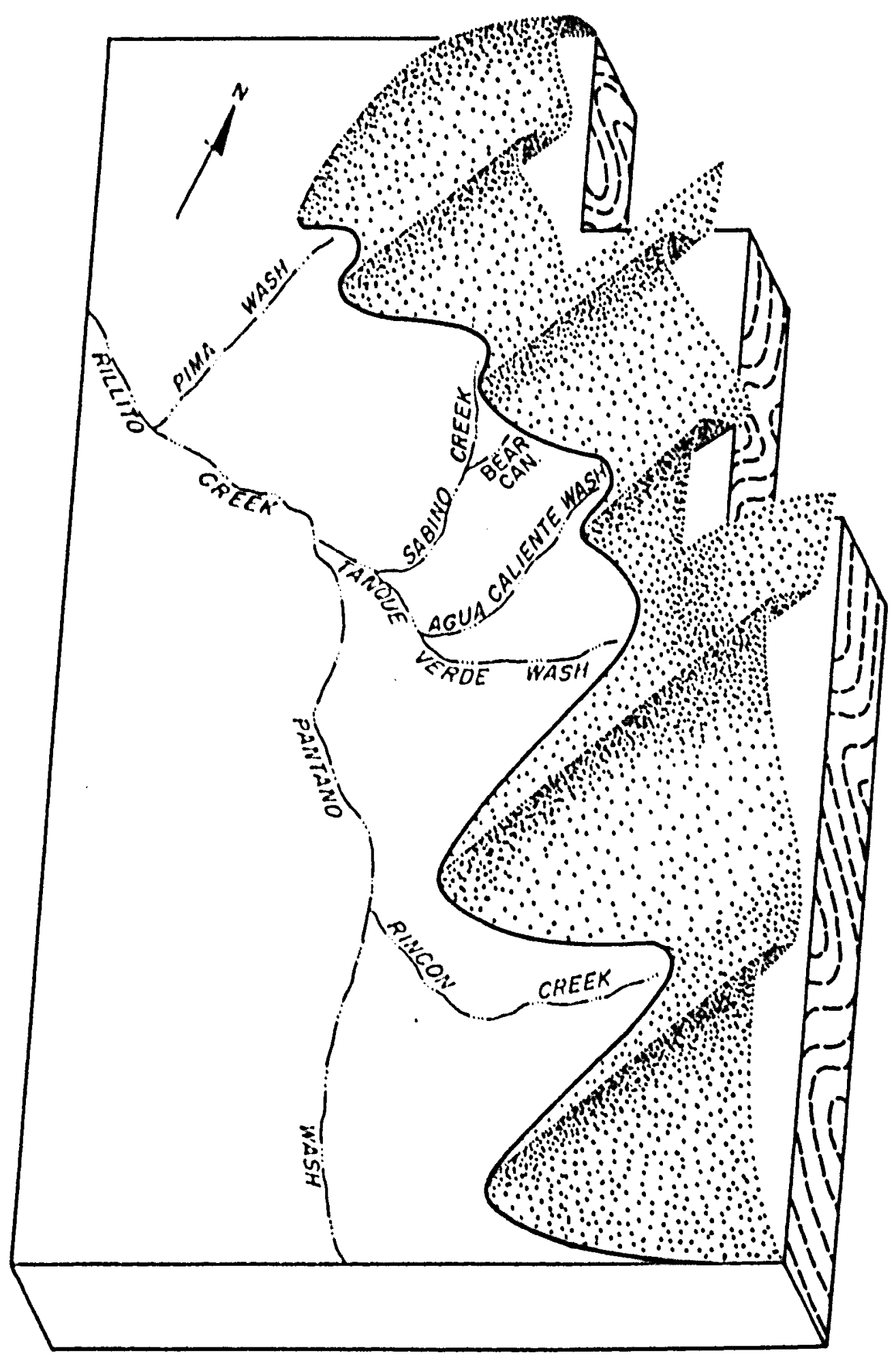

Fingure 11, - - Cieneralized diagram showing, the restored folds in the simbla Cilalina, Thangue: Verde, and Rincon Mountains. 
Likewise the irregularities of the base line of these ranges, from the southwest tip of the Catalinas to the southeast tip of the Rincons, closely parallel the outcrop pattern produced in the layers of gnciss by these plunging anticlines and synclines. Outstanding examples of this are: the offset of the front of the Catalinas near the mouth of Sabino Canyon, which reflects the west-southwest-plunging nose of the Sabino-Benr Canyon anticline; the reentrant in the base line between the Santa Catalina Mountains and Agua Caliente Hill, which reflects the outcrop pattern produced by the plunging Molino Canyon syncline; the west-southwest-pointing V-shaped outline of the base line of the Tanque Verde Mountains, which reflects the outcrop pattern of the plunging Tanque Verde anticline; and the east-northeast-pointing V-shaped base line of Rincon Valley, which reflects the outcrop pattern of the plunging Rincon Valley syncline. Many individual cases exist where the mountain base line appears to transect the internal structure of the ranges, but in general the two are more nearly parallel.

Thus, it can be seen that it is not necessary to call upon a series of cast-west-trending border faults, offset by a series of northsouth-trending transverse faults, to explain the irregularities in the base line of these ranges. Instead, its configuration is shown to reflect the outcrop pattern produced by a series of parallel west-southwestplunging anticlines and synclines, which constitute the internal structure of the Rincon, Tanque Verde, and southern Catalina Mountains. 


\section{THE CATALINA FAULT}

\section{$\underline{\text { Introduction }}$}

The name Catalina fault is used here to define a low-angle fault exposed in many places over a distance of more than 50 miles along the southern base of the Santa Catalina Mountains, the western base of Agua Caliente Hill, and the northwestern and southern bases of the Tanque Verde and Rincon Mountains. The fault separates the Catalina Gneiss of the ranges from a wide varicty of rock types, excluding gneiss of the pledmont slopes.

\section{Previous Work}

Some workers have described the movement along the Catalina fault as normal; others have described it as reverse. Davis (1931, p. 280-290) predicted, on the basis of a physiographic analysis of the Santa Catalina Mountains, that the mountains were bounded on the south by a high-angle normal fault. Moore and others (1941, p. 16-17) show the trace of this fault on their map and describe it as a thrust with a dip of $10^{\circ}$ to $40^{\circ}$ to the south and west. 
An intermedinte position was taken by Fair and Jinks (1961, p. 131-132), who studied the fault along the south side of the Catalinas. They conclude that the fault represents a zone of structural weakness that was subjected to recurrent stress and movement and that the movement nlong the fault, at least in its final phase, was normal.

\section{The Trace of the Catalina Fault}

The trace of the Catalina fault is shown on plate 1 as a solid line where the fault is actually exposed or where it could be located within a few feet of its actual position. Along much of the southern front of the Catalina Mountains and the northwest front of the Tanque Verde Mountains, where the fault is concealed by younger deposits, it is shown as a dotted line. Even where the fault is concealed, its position often may be determined within narrow limits by examining the ballings dumps of numerous wells drilled in its vicinity. Wells drilled south of the fault along the front of the Catalina Mountains or northwest of the fault along the front of the Tanque Verde Mountains have a red or reddish-gray ballings dump as the result of the bit penetrating the red to reddish-gray sediments that compose the upper plate of the Catalina fault. Thus, the fault is always located between the red dumps and the nearest outcrop of Catalina Gneiss.

This Information and the exposures of the fault give good control for its position along the front of the Catalina Mountains cast of its 
westernmost exposure in sec. 33, T. 12 S., R. 14 E. West of there the fault is concealed, and well-site data are insufficient to determine Its position.

Exposures and well dumps accurately define the position of the fault along the base of Agua Caliente Hill and most of the northwest side of the Tanque Verde Mountains. The fault is concealed along the southwest tip of the Tanque Verde Mountains, and no well data are available to support the trace of the fault shown on plate 1.

The fault is exposed almost continuously along the south side of the Tanque Verde Mountains and the northwest and southern sides of the Rincon Mountains.

There is some possibility that the Catalina fault, or a slice of the fault, extends into Tanque Verde Canyon. This is shown on plate 1 as a hypothetical fault. If this is the case, the isolated exposures of limestone, and the rocks mapped as Catalina Gneiss west of the limestonc in scc. 35, T. $13 \mathrm{~S} ., \mathrm{R}, 16 \mathrm{E}$, , are part of the slice and lie in fault conlact on the Catalina Gneiss.

Parallelism Between the Fault and the Folds in the Gneiss

The trace of the Catalina fault (pl. 1) closely parallels the sinuositles of the topographic base line of the Santa Catalina, Tanque Verde, and Rincon Mountains. Dip measurements made on the fault 
plane reveal that it dips away from the mountains at angles that range from $8^{\circ}$ to $53^{\circ}$ (table 4 ).

In a preceding section on the internal structure of the ranges It was shown that the shape of the ranges reflects the configuration of a series of west-southwest-plunging anticlines and synclines formed from the layered gneiss. The gneiss layers exposed along the base of the ranges, in general, strike parallel to the trend of the topographic base line of the ranges and its sinuosities and dip away from the mountain front.

From the descriptions of the attitude of the fault and the attitude of the gnelss, it can be concluded that the fault surface is approximately parallel to the laycring in the underlying gneiss. The surface of the Catalina fault shows the same pattern of west-southwest-plunging anticlines and synclines as is present in the underlying gneiss.

\section{Rocks of the Upper Plate}

The rocks of the upper plate of the Catalina fault are, for purposes of this discussion, grouped into two categories based on structure and agc. Thesc categories are: (1) folded rocks of pre-late Tertiary age, and (2) fractured rocks of late Tertiary age. 
TABLE 4

SUMMARY OF DIP MEASUREMENTS ON THE CATALNA EAULT

\begin{tabular}{|c|c|c|c|}
\hline LOCATION & DIP & METHOD OF DETER MANATION & FAULT RELATIONSIIP \\
\hline $\begin{array}{l}(D-12-14) 33 \\
S W . . S W . . S E\end{array}$ & $21^{\bullet-23 \cdot 5 .}$ & $\begin{array}{l}\text { Three-polnt wolutlor } 500 \text { teet } \\
\text { between mout d!atant polnts }\end{array}$ & $\begin{array}{l}\text { Rullto beds (ivpe I) } \\
\text { orer Cataltina Cnelss }\end{array}$ \\
\hline $\begin{array}{l}(0-12-1+1) 33 \\
5 W . .54 . .5 E\end{array}$ & $19 \mathrm{~S}$ & $\begin{array}{l}\text { Compase measurement on } \\
\text { excellent exposure of tauls } \\
\text { surface }\end{array}$ & $\begin{array}{l}\text { Rululeo beds (type I) } \\
\text { over Catalina Grelss }\end{array}$ \\
\hline $\begin{array}{l}(D-[3-14)] \\
\mathrm{NE} . \mathrm{SE} . . \mathrm{NW}\end{array}$ & 45. s. & $\begin{array}{l}\text { Compase measurement of fault } \\
\text { plane exposed in croses section }\end{array}$ & $\begin{array}{l}\text { Rllltio beds (type I) } \\
\text { orer Calalina Gnelse }\end{array}$ \\
\hline $\begin{array}{l}(D-13-14) 2 \\
S W . . S E . N W\end{array}$ & $47^{\circ}-53^{\circ} \mathrm{S}$ & $\begin{array}{l}\text { Compass measurement of small } \\
\text { exposure of fault plane }\end{array}$ & $\begin{array}{l}\text { Rullto beds (type II) } \\
\text { over Catalina Gnetsa }\end{array}$ \\
\hline $\begin{array}{l}(D-13-15) 6 \\
5 w . .5 W . . N W .\end{array}$ & 325 & $\begin{array}{l}\text { Compess measurement of small } \\
\text { exposure of fault plane }\end{array}$ & $\begin{array}{l}\text { Rillito beds (type II) } \\
\text { over Catalina Gneiss }\end{array}$ \\
\hline $\begin{array}{l}(D-14-16) 15 \\
5 W . .5 W . . N E . . N W .\end{array}$ & $17^{\circ} \mathrm{Nw}$. & $\begin{array}{l}\text { Compass measurement of ex- } \\
\text { cellent exposure of fault plane }\end{array}$ & $\begin{array}{l}\text { Granite over Catalina } \\
\text { Gnelss }\end{array}$ \\
\hline $\begin{array}{l}(D-14-16) 28 \\
\text { Westera half }\end{array}$ & $\begin{array}{l}\text { Wavy surface } \\
\mathrm{B}^{\circ}-21^{\bullet} \mathrm{NW}\end{array}$ & $\begin{array}{l}\text { Series of three-point solutions } \\
\text { using } 9 \text { points }\end{array}$ & $\begin{array}{l}\text { Folded limestone over } \\
\text { Catalina Gneise }\end{array}$ \\
\hline $\begin{array}{l}(D-15-17) 8 \\
\text { SE. SE. SW. }\end{array}$ & $300 \mathrm{~s}$ & $\begin{array}{l}\text { Compass measurement on fault } \\
\text { plane }\end{array}$ & $\begin{array}{l}\text { Folded limestone over } \\
\text { Catalina Gneiss }\end{array}$ \\
\hline $\begin{array}{l}(D-15-17) 10 \\
\text { SW.. NW.. SE. }\end{array}$ & $24^{\circ} \mathrm{s}$ & $\begin{array}{l}\text { Compass measurement on fault } \\
\text { plane }\end{array}$ & $\begin{array}{l}\text { Folded limestone over } \\
\text { Catalina Gnelas }\end{array}$ \\
\hline $\begin{array}{l}(D-15-17) 10 \\
\text { SE. NE. SE. }\end{array}$ & $33^{\circ} \mathrm{S}$ & $\begin{array}{l}\text { Compeas measurement on fault } \\
\text { plane }\end{array}$ & $\begin{array}{l}\text { Folded limeatone over } \\
\text { Catalina Gnelss }\end{array}$ \\
\hline $\begin{array}{l}(D-18-18) 16 \\
\text { SW.. SW.. SE. }\end{array}$ & $17^{\bullet}-22^{\bullet} \mathrm{S}$. & $\begin{array}{l}\text { Compass measurement on fault } \\
\text { plane }\end{array}$ & $\begin{array}{l}\text { Folded limestone over } \\
\text { Catallna Gnelss }\end{array}$ \\
\hline
\end{tabular}


Folded Rocks of Pre-Late Tertiary Age

The pre-late Tertiary rocks include limestone, quartzite, shale, conglomerate, mudstone, sandstone, schist, granite, and volcanic rocks. They range in age from Cambrian to middle Tertiary. Rocks that may be of middle Tertiary age crop out at many places along the borders of the Santa Catalina, Tanque Verde, and Rincon Mountains, but they were mapped only along the south edge of the Santa Catalina Mountains and the northwest edge of the Tanque Verde Mountains (pl, 1). Rocks ranging in age from Cambrian to Cretaceous crop out along the northwest and south edges of the Tanque Verde and Rincon Mountains but were not mapped. Information concerning the structure of the rocks of the upper plate along the edges of the Tanque Verde and Rincon Mountains comes largely from the works of others (Moore and others, 1941; Layton, 1957; Acker, 1958; Kerns, 1958; McColly, 1961; and Brennan, 1962).

McColly (1961, p. 54-55) describes a "large recumbent isoclinal fold" in the Palcozoic rocks on the northwest side of the Tanque Verde Mountains, but he did not report its orientation.

A prominent fold in the Paleozoic rocks of the Colossal Cave arca (fig. 12A) was observed by Acker (1958, p. 30), who describes it as "a faulted remnant of a huge recumbent fold whose axis trends $\mathrm{N}$. $50^{\circ} \mathrm{E} .$, and plunges gently to the northeast. "The present author 


\title{
FOLDS IN PALEOZOIC ROCKS OF THE UPPER PLATE
}

\begin{abstract}
A.
Recumbent fold in Paleozoic rocks of the upper plute of the Catalina fault in the Colossal Cave area.
\end{abstract}

B.

Large drag fold in Palcozole limestone of the upper plate of the Catalina fault. The fault plane at thls locallty is locnted at the base of the cliff and dips at a very low angle. The exposure is in the SE-1/4SW-1/4SE-1/4NW-1/4 scc. 10, T. 15 S. , R. $17 \mathrm{E}$. 

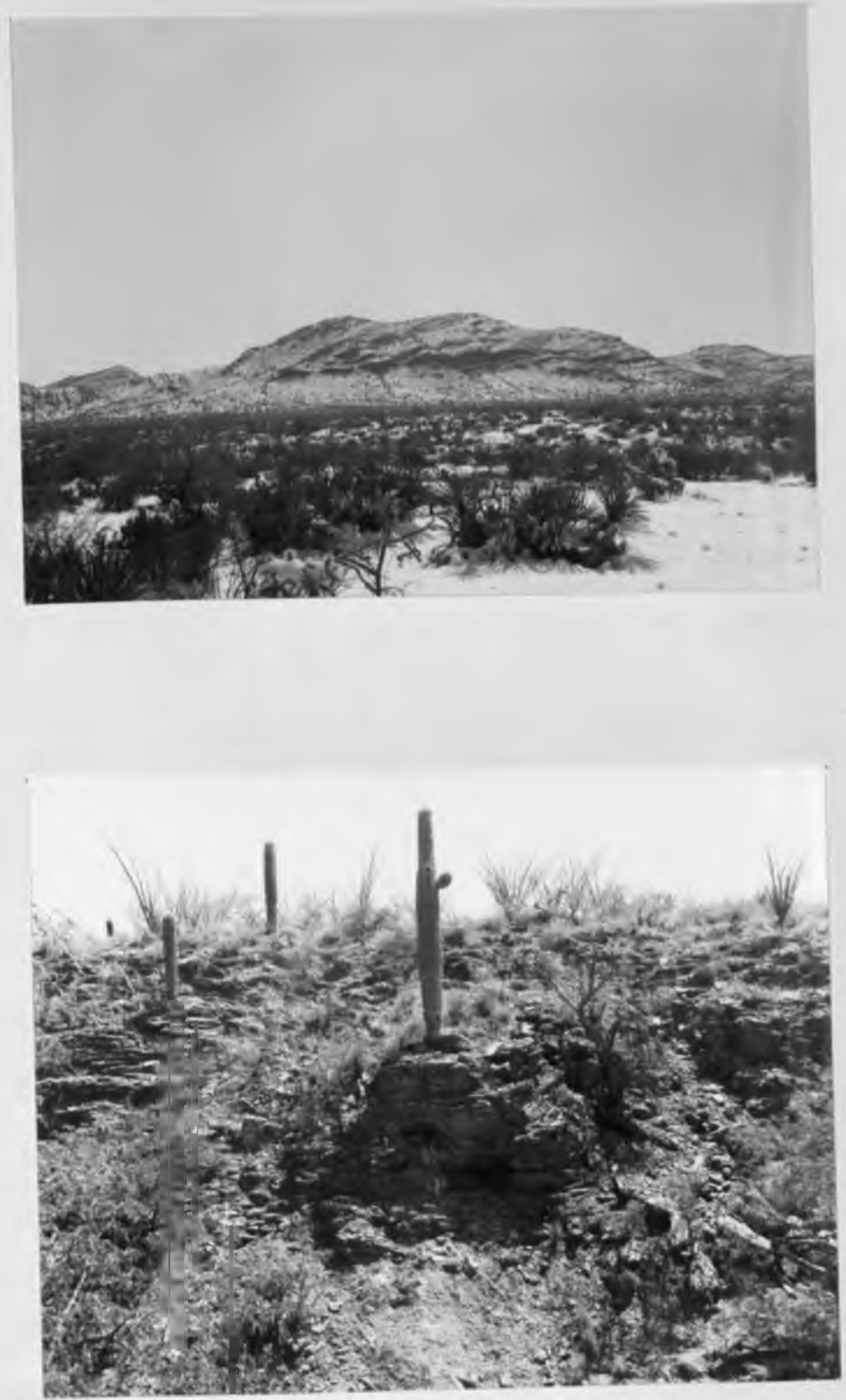
observed a large drag fold (fig. 12B) in the SE-1/4SW-1/4SE-1/4NW-1/4 sec. 10, T. 15 S., R. 17 E., about 5 miles north-northeast of Colossal Cave. The fold involves thin-bedded red Paleozoic limestone that lies directly on the Catalina fault. The axis of the fold trends about N. $70^{\circ}$ E. and plunges $8^{\circ}$ NE. The orientation of the fold indicates it was formed by the limestone sliding northwest over the fault plane.

Brennan (1062, p. 47, 56-57) describes east-northeast-trending shallow folds involving the middle Tertiary Pantano Formation of the Cienega Gap area south of the Rincon Mountains. He also reports thrust blocks of Cretaccous and Paleozoic rocks lying on the Pantano Formation and postulates compressive stress from the southeast as being responsible for the thrust blocks and the folds in the Pantano Formation.

\section{Fractured Rocks of Late Tertiary Age}

The late Tertiary fractured rocks consist mainly of sandstone and conglomerate. These rocks crop out and were mapped in the piedmont area along the northwestern and southern sides of the Santa Catalina Mountains. They were observed but not mapped in the foothills along the southern side of the Rincon Mountains. These rocks are cut by many joints and steep normal faults but show little sign of being involved in folding and thrusting. 
The normal faults (pl, 1) trend northeast and northwest and do not offset or cross the Catalina fault or the front of the ranges.

\section{Hypothesis Regarding Two Periods of Displacement}

The differences in the structure between the pre-late Tertiary rocks and the late Tertiary rocks can be used in formulating a hypothesis for two distinct periods of displacement along the Catalina fault. The first period consisted of folding and thrust faulting, including thrust movement along the Catalina fault, and terminated in mid-Tertiary time. This folding and thrusting elevated the Santa Catalina, Tanque Verde, and Rincon Mountains and was followed or accompanied by erosion within the mountains and deposition of late Tertiary sediments along their edges.

The second period of displacement consisted of normal faulting that involved rocks of late Tertiary àge and older and was accompanied by normal movement along the Catalina fault. This period of faulting had little effect on the outline of the Tucson basin, which still reflected the folds in the Catalina Gneiss.

First Period-Thrusting and Folding

The thrust blocks of Cretaceous and Paleozoic rocks lying on the Pantano Formation and the east-northeast-trending folds in the Pantano Formation (Brennan, 1962, p. 56-57), in the Paleozoic rocks, 
and in the Catalina Gneiss indicate that all these rocks were involved in a period of thrusting and folding that, at least in part, was as young as middle Tertiary. The parallelism of the folds in these rocks may indicate a response to regional horizontal compression perpendicular to their axes. This postulated compression direction is compatible with a north-northwest direction of thrusting involving middle Tertiary rocks in the Pima mining district 15 to 30 miles south-southwest of Tucson (Cooper, 1960, p. 89, 98) and thrusting from the southeast involving Cretaceous rocks in the Empire Mountains (Galbraith, 1959, p. 132). The parallelism between the surface of the Catalina fault and the broad folds in the underlying Catalina Gneiss can be explained by postulating that the fault formed as a bedding thrust or decollement (Billings, 1942, p. 173) during the folding of a thick section of layered rocks. Early in the folding, flexing of the layers at depth took place by slippage within and between the layers, resulting in the lineation, foliation, and folds in the Catalina Gneiss. At shallower depths, folding also took place, but under conditions nonconducive for the development of follation and lineation. As folding progressed, slippage became concentrated at a single horizon, perhaps at a prominent change in lithology or competency, and developed into a bedding thrust or decollement. After this thrust formed, folding in the underlying Catalina Gneiss probably ceased, but folding in the upper plate may have continued as the block moved north-northwest. Continued movement along the thrust 
eventually resulted in the juxtaposition of rocks of the upper plate, folded under conditions of temperature and pressure that were too low to permit metamorphism, over gneiss whose tectonite fabric may reflect the same stress that folded the rocks of the upper plate.

The age of the folds in the Catalina Gneiss and in the Paleozoic and Cretaceous rocks is uncertain and may be Late Cretaceous or early Tertiary. Damon has suggested that the late Oligocene-early Miocene potassium-argon apparent age of the Catalina Gneiss reflects the uplifting of the mountain mass by block faulting (Damon and others, 1963, p. 119). I would modify this slightly and suggest the possibility that it may reflect uplift of the mountain mass, not by block faulting, but by folding, and that the late Oligocene-early Miocene date represents a possible minimum age of the folds in the Catalina Gneiss. The origin of the ranges by folding and thrusting is supported by the close relationship between their shape and the configuration of the folds in the Catalina Gneiss.

An alternate hypothesis to explain the Catalina fault and the - folds in the upper plate is that the Catalina fault is a glide plane along which the rocks of the upper plate slid off the flanks of the ranges as they were elevated. Detalled mapping of the structures of the upper plate adjacent to the Rincon and Tanque Verde Mountains is needed to evaluate this hypothesis. 
Figures 13 through 18 show exposures of the Catalina fault at localities where the upper plate is composed of folded Paleozoic rocks or granite.

\section{Second Period-Normal Faulting}

The first period of folding and thrusting elevated the Santa Catalina, Tanque Verde, and Rincon Mountains in essentially their present positions. The mountain ranges were subjected to extensive erosion that cut into and removed most of the folded rocks of the upper plate and exposed the underlying Catalina Gneiss. The material eroded from the ranges was deposited along their edges and formed the late Tertiary deposits. Pebbles in these deposits include limestone, quartzite, volcanic rocks, and granite, derived mainly from crosion of the upper plate, and gneiss, which became increasingly more abundant as erosion cut through the upper plate and exposed the lower plate of the Catalina fault.

In late Tertiary time the rocks of the upper plate were broken into a series of tilted blocks by sets of northeast- and northwest-trending stecp normal faults. The northeast-trending faults appear to stop at the front of the Catalina Mountains and do not offset the range or the Catalina fault. Nlong their horizontal projection the northwest-trending faults intersect the Catalina fault at a low angle and probably become tangential to it. It seems logical to suggest that the 
FIGURE 13

FOLDED PRE-LATE TERTIARY ROCKS OF THE UPPER PLATE

Looking southeast at folded Paleozoic rocks lying on the Catalina fault in the Colossal Cave area. The Catalina fault lies just above the prominent ledge in the left half of the photo and dips gently to the right or southwest. 


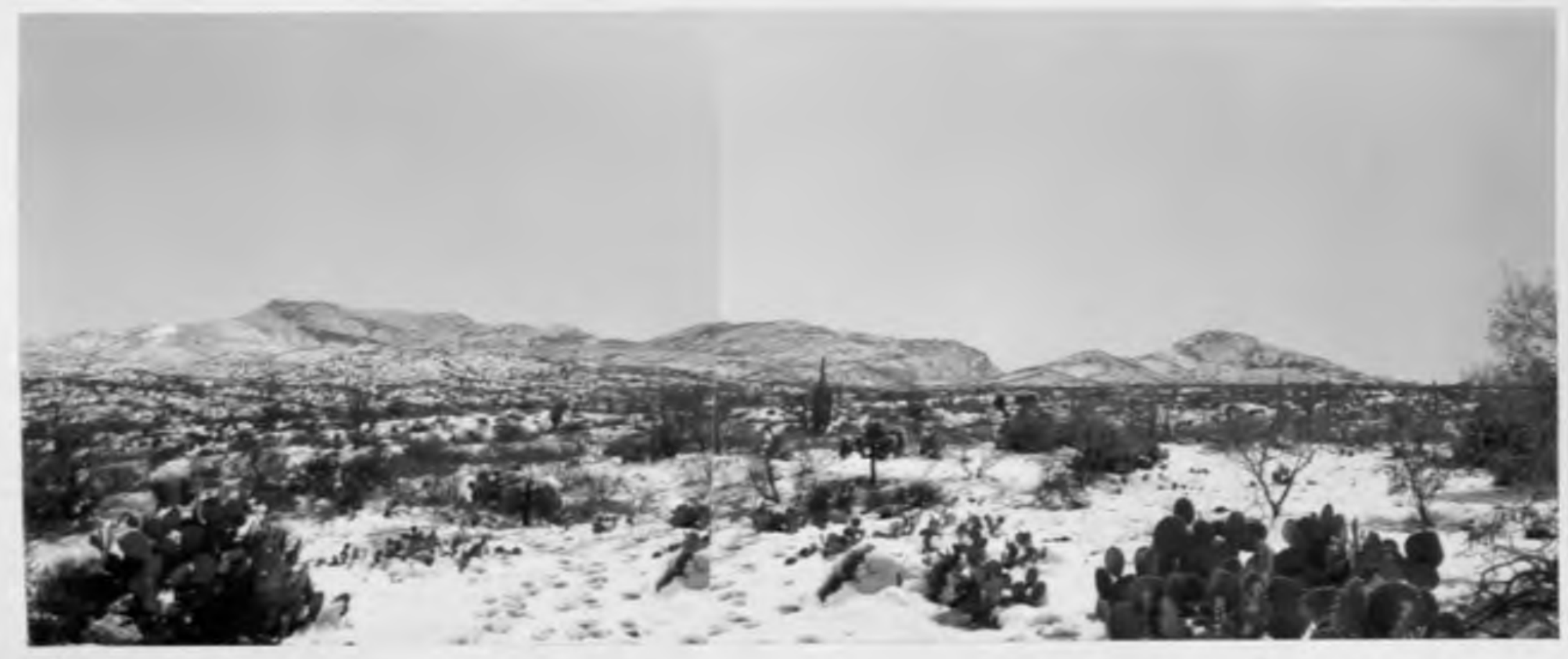


FIGURE 14

CATALINA FAULT, TANQUE VERDE MOUNTAINS

Exposure of the Catalina fault on the northwest side of the Tanque Verde Mountains. The fault dips gently to the northwest and is overlain by folded Paleozoic limestone. The exposure is in sec. 28, T. 14 S., R. 16 E. Photo taken looking northeast. 


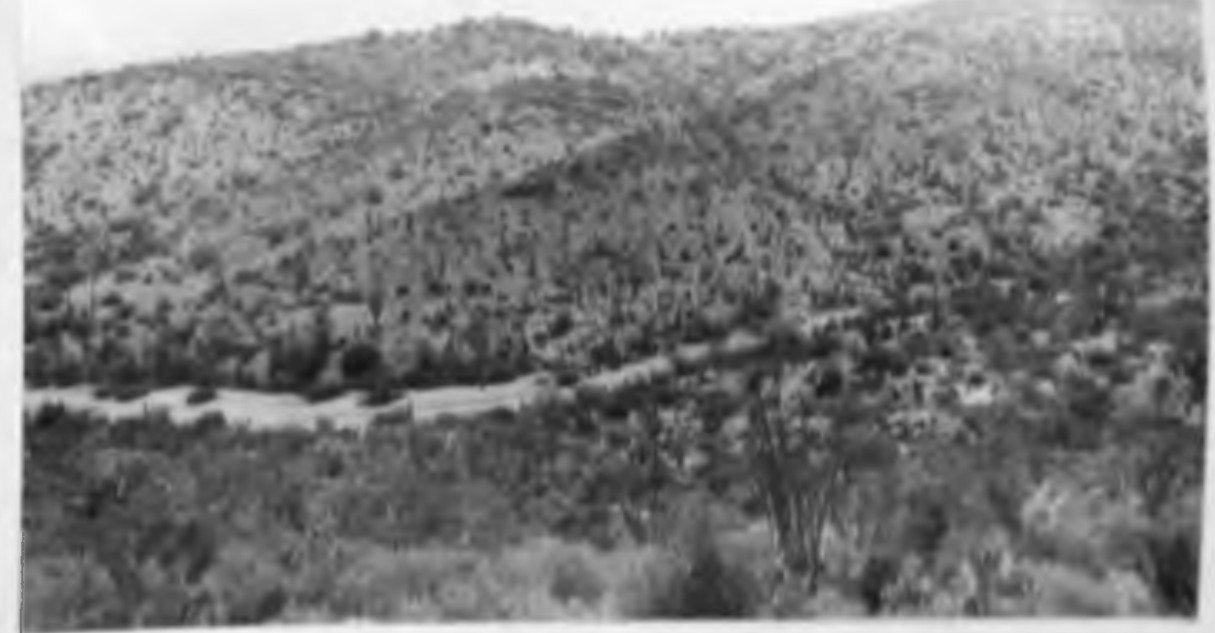




\title{
FIGURE 15
}

CATALINA FAULT, SOUTHWEST RINCON MOUNTAINS

\begin{abstract}
A.
Exposure of the Catalina fault along the west cdge of sec, 2, $\mathrm{T}$. $16 \mathrm{~S}$, R. $17 \mathrm{E}$. The steep cliff along the crest of the ridge is formed of folded Paleozoic limestone. The gently dipping Catalina fault is at the base of the cliffs and is underlain by the Catalina Gneiss, which forms the lower three-fourths of the ridge. Photo taken looking west.
\end{abstract}

B. Exposure of the Catalina fault in sec. 3, T. 16 S., R. 17 E. This is the same ridge pictured above but as scen from its west side. The Catalina fault is above the massive ledge about halfway. down the side of the ridge. Photo taken looking cast. 

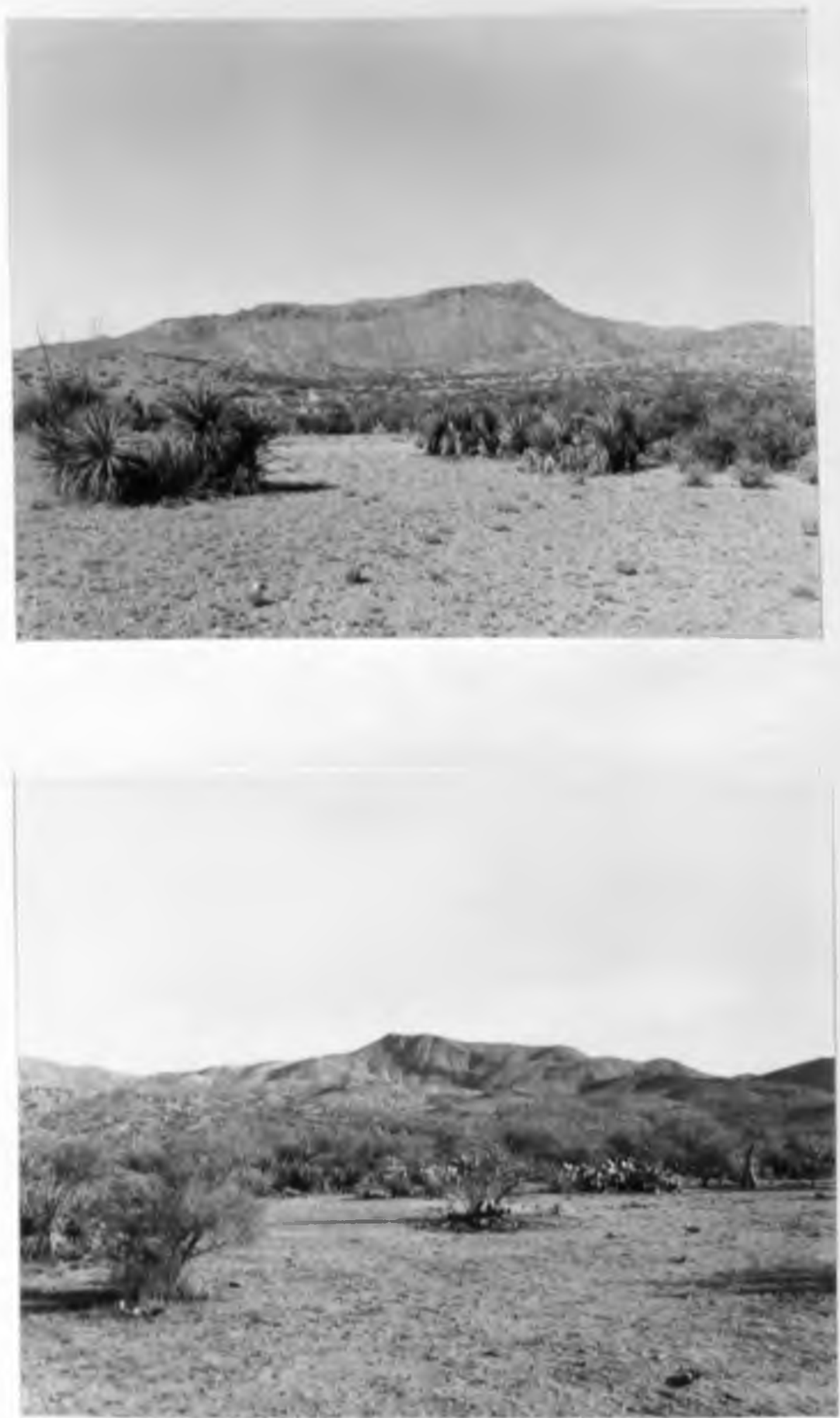
FIGURE 16

CATALINA FAULT, SOUTHERN RINCON MOUNTAINS

A. The Catalina fault exposed in cross section along the south side of the Rincon Mountains. The fault plane exposed in the center of the picture dips south at an angle of from $17^{\circ}$ to $22^{\circ}$. Rocks of the upper plate consist of folded Palcozolc limestonc. The exposure is in the SW-1/4SW-1/4SE-1/4 sec. 16, T. $16 \mathrm{~S} ., \mathrm{R}$. $18 \mathrm{E}$. The ridge on the skyline is a distant cxposure of the same fault and is shown on figure $15 \mathrm{~A}$.

B.

Closeup of the exposure of the fault plane shown in the center of the photo above. 

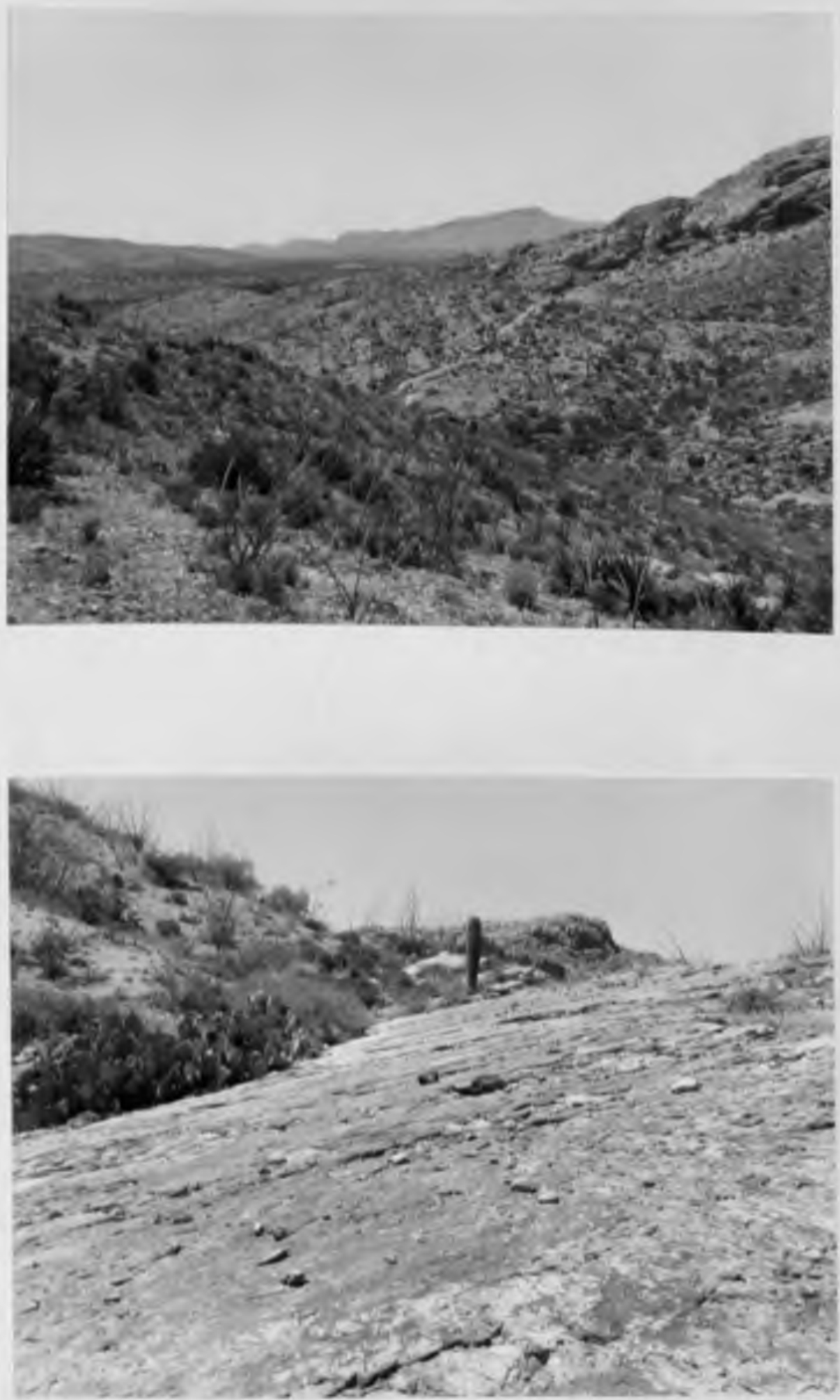
FIGURE 17

CATALINA FAULT, SOUTHERN RINCON MOUNTAINS

(Photo by Tad Nichols)

Exposures of the Catalina fault along the south side of the Rincon Mountains. The dark rocks forming the ridge in the center of the photo are folded Paleozoic rocks of the upper plate. The fault dips south at a low angle and is about at the foot of the ridge on the north side. Rocks in the right edge of the picture arc Catalina Gneiss. Photo taken looking west. 


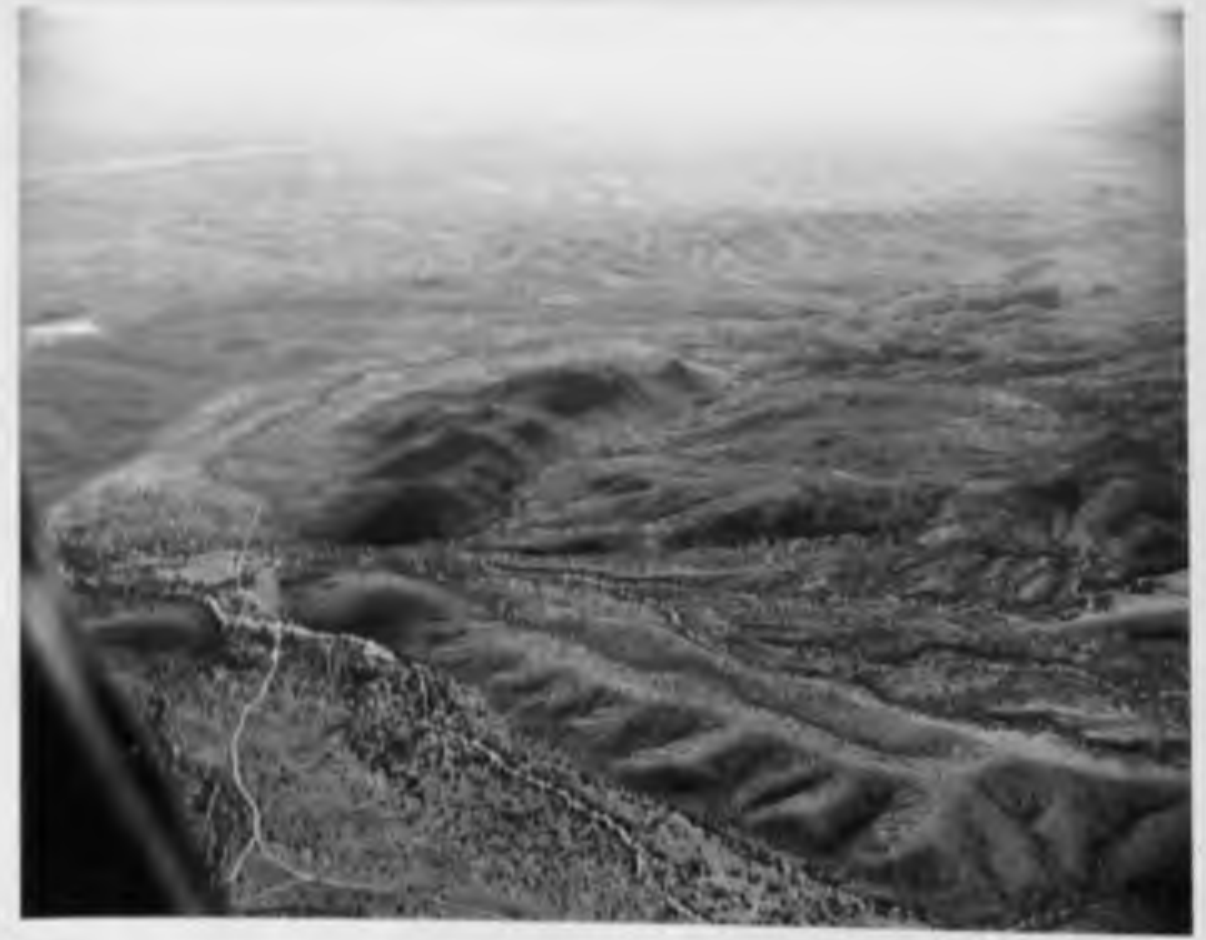




\title{
FIGURE 18
}

\section{PLANE OF THE CATALINA FAULT}

\begin{abstract}
A.
Exposure of the plane of the Catalina fault in the SW-1/4SW$1 / 4 \mathrm{NE}-1 / 4 \mathrm{NW}-1 / 4$ sec. 15, T. 14 S., R. $16 \mathrm{E}$. Here a very intensely fractured granite overlies the fault and is being slowly stripped away revealing a very good exposure of the fault plane, which dips $17^{\circ} \mathrm{NW}$.
\end{abstract}

B.

Same locality as above. 

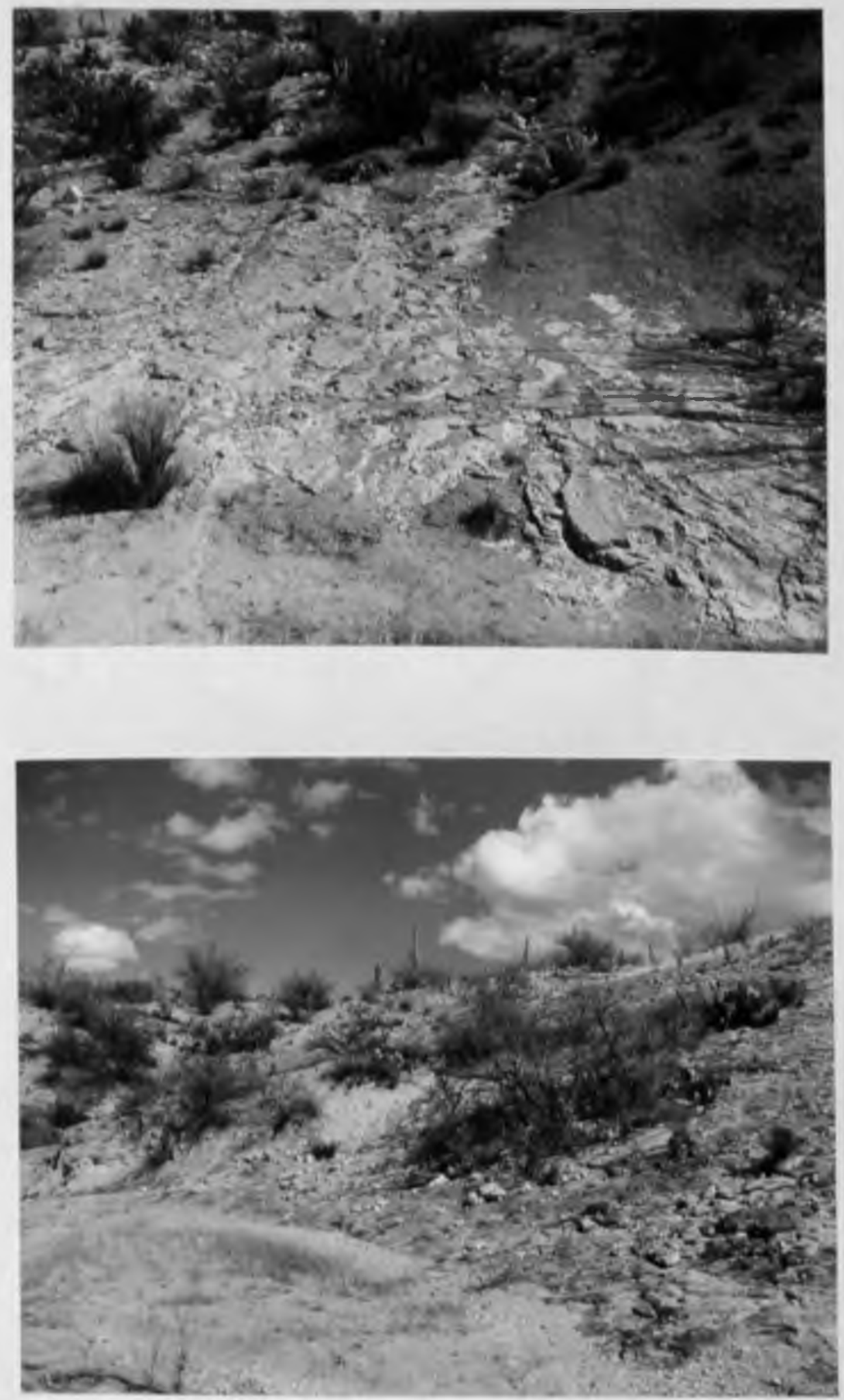
northwest-trending set also becomes tangential to the Catalina fault along its downdip projection as well.

Adjacent to the range, individual blocks are bounded on three sides by northwest- and northeast-trending normal faults and on the fourth side by the Catalina fault. Differential movement between the individual blocks took place along the normal faults and was accompanied by normal displacement along the Catalina fault. Continued movement resulted in rocks of late Tertiary age and older being faulted into contact with the gneiss along the Catalina fault. Figure 19 shows middle or late Tertiary rocks in contact with the Catalina Gneiss along the Catalina fault.

\section{Wells and Springs Along the Catalina Fault}

Many of the wells and springs along the front of the Santa Catalina Mountains are near the Catalina fault. A generalized north-south geologic cross section (fig. 20) across the fault along the front of the Catalina Mountains shows the relation of springs and wells to the fault. Wells $A, B$, and $C$ show typical conditions encountered, depending on the location of the well site.

Water in the gneiss fills fractures and is under artesian conditions south of the fault and is unconfined north of the fault. The artesian conditions are preserved by the generally impermeable mudstone 
FIGURE 19

FAN REMNANTS, EXHUMED PEDIMENT, AND THE CATALINA FAULT NEAR CAMPBELL AVENUE

(Photo by Jay Dusard)

The hill to the right is an erosional remnant of an alluvial fan. The fan lies on the Rillito surface, which bevels type I Rillito beds in the southern (right) two-thirds of the photo and the Catalina Gneiss and Catalina fault in the northern third. The Rillito surface has been exhumed in the northern two-thirds of the photo. The Catalina fault dips south at an angle of about $21^{\circ}$ to $25^{\circ}$ and separates the Catalina Gneiss from the Rlllito beds. 


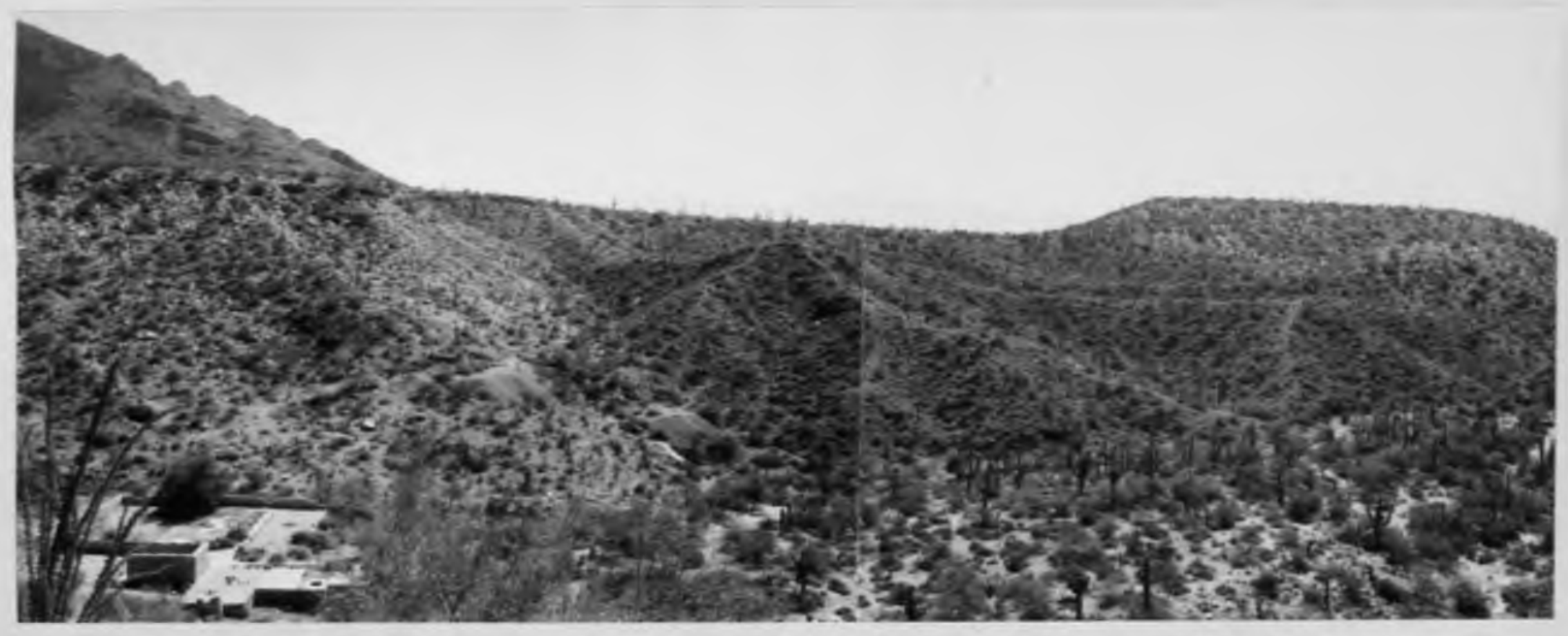




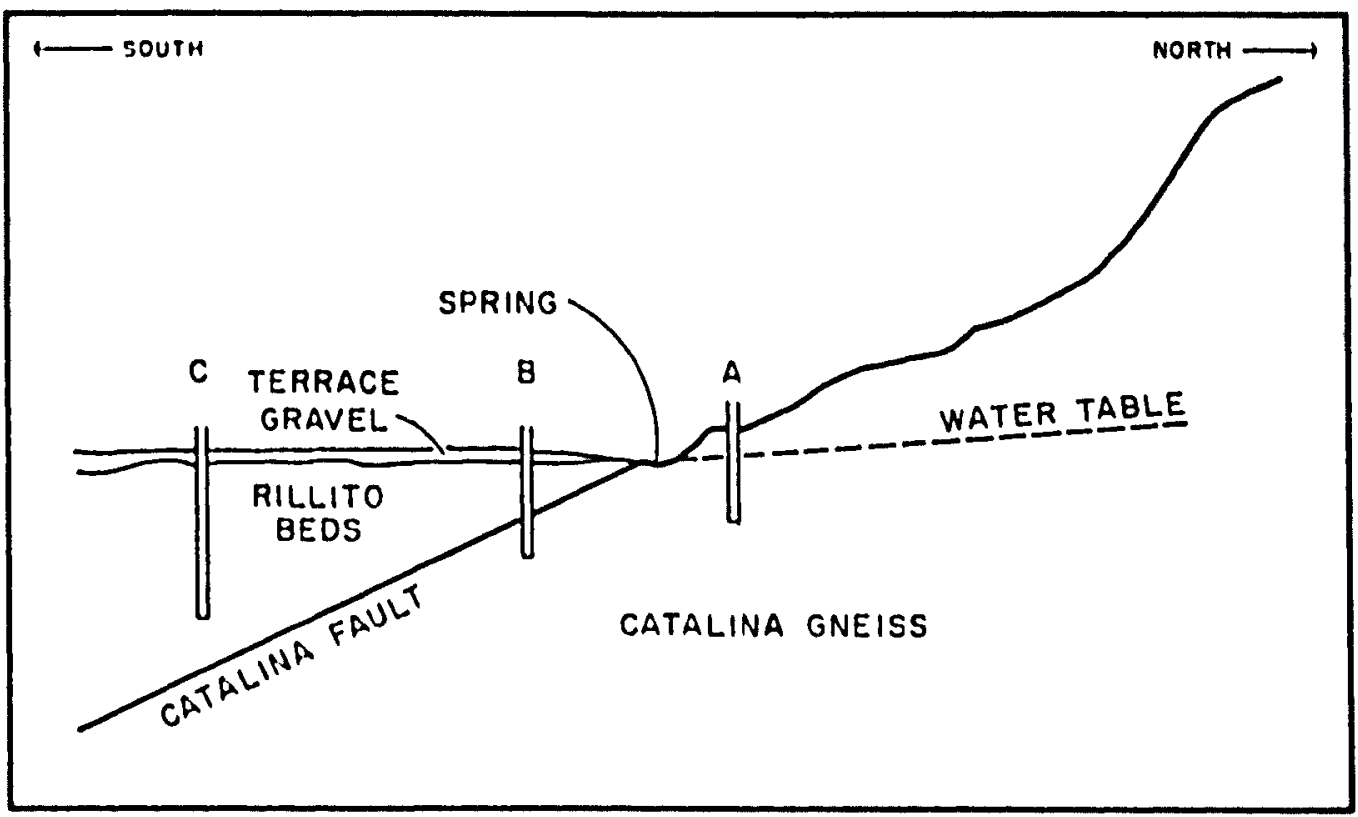

Figure 20.--Gencralized north-south geologic cross section across the southern front of the Santa Catalina Mountains, showing the relation of well-site locations to geology. 
and conglomerate that lie above the fault plane and form the hangingwall block of the Catalina fault.

Well $A$, a few feet north of the fault, is directly in the gneiss. The depth to water is usually shallow and at about the same altitude as the outcrop of the fault south of the well site.

Well $B$ is a short distance south of the Catalina fault and may penetrate as much as 60 feet of terrace gravel overlying a variable thickness of red to reddish-gray deposits of the hanging-wall block of the fault before entering the gneiss. The thickness of red beds penetrated depends on the dip of the Catalina fault and the distance of the well site south of the outcrop of the fault. The water in the well will rise immediately when the fault is penetrated and may even flow.

Well $\mathrm{C}$ is not deep enough to penetrate the fault and must depend on water in the impermeable red mudstone and conglomerate for its supply. Many such wells have been drilled and abandoned due to poor quality or insufficient quantity.

Many small springs have been developed along the south front of the Catalina Mountains between the mouth of Bear and Soldier Canyons. They flow from the gneiss a few feet north of the Catalina fault or from alluvium overlying the fault. The springs respond to seasonal variation in streamflow and rainfall in the Catalina Mountains. They may be supplied by recharge rejected by the gneiss artesian aquifer at the position of the Catalina fault. 
Wells and springs that obtain their water from the gneiss generally yield from 1 to $6 \mathrm{gpm}$ (gallons per minute). Springs of greater yield than those described above are on the Catalina fault at La Cebadilla Ranch (NE-1/4 sec. 3, T. 14 S., R. 16 E.), Tanque Verde Ranch (SW-1/4 sec. 2, T. 14 S., R. 16 E.), and Agua Caliente Ranch (SE-1/4SW-1/4 sec. 20, T. 13 S., R. 16 E.). The fluoride content of the water taken from eight wells and springs ranged from $2.6 \mathrm{ppm}$ (parts per million) to $11 \mathrm{ppm}$. 


\section{GEOLOGY OF THE PIEDMONT REGION}

Stratigraphy and Structure of the Rillito Beds

\section{Introduction}

Much of the margin of the Tucson basin-along the edges of the Santa Catalina and Tanque Verde Mountains - is underlain directly by tilted, faulted, and jointed conglomerate, sandstone, and mudstone. These structurally disturbed deposits, referred to in this report as the Rlllito beds, exhibit a great variety of induration, color, and pebble composition, and several formations, differing in age and origin, are represented.

For the purposes of this report, the Rillito beds have been divided into types I, II, and III, based on the composition of their pebbles and the presence or absence of mudstone units.

The Rillito beds are tilted and broken by normal faults of major displacement, which divide the units into a series of tilted blocks that are indexed on figure 21 (A through $\mathrm{N}$ ). The beds in the individual blocks, separated by these major faults, are broken by hundreds of faults showing displacements ranging from a few inches to a few feet. 


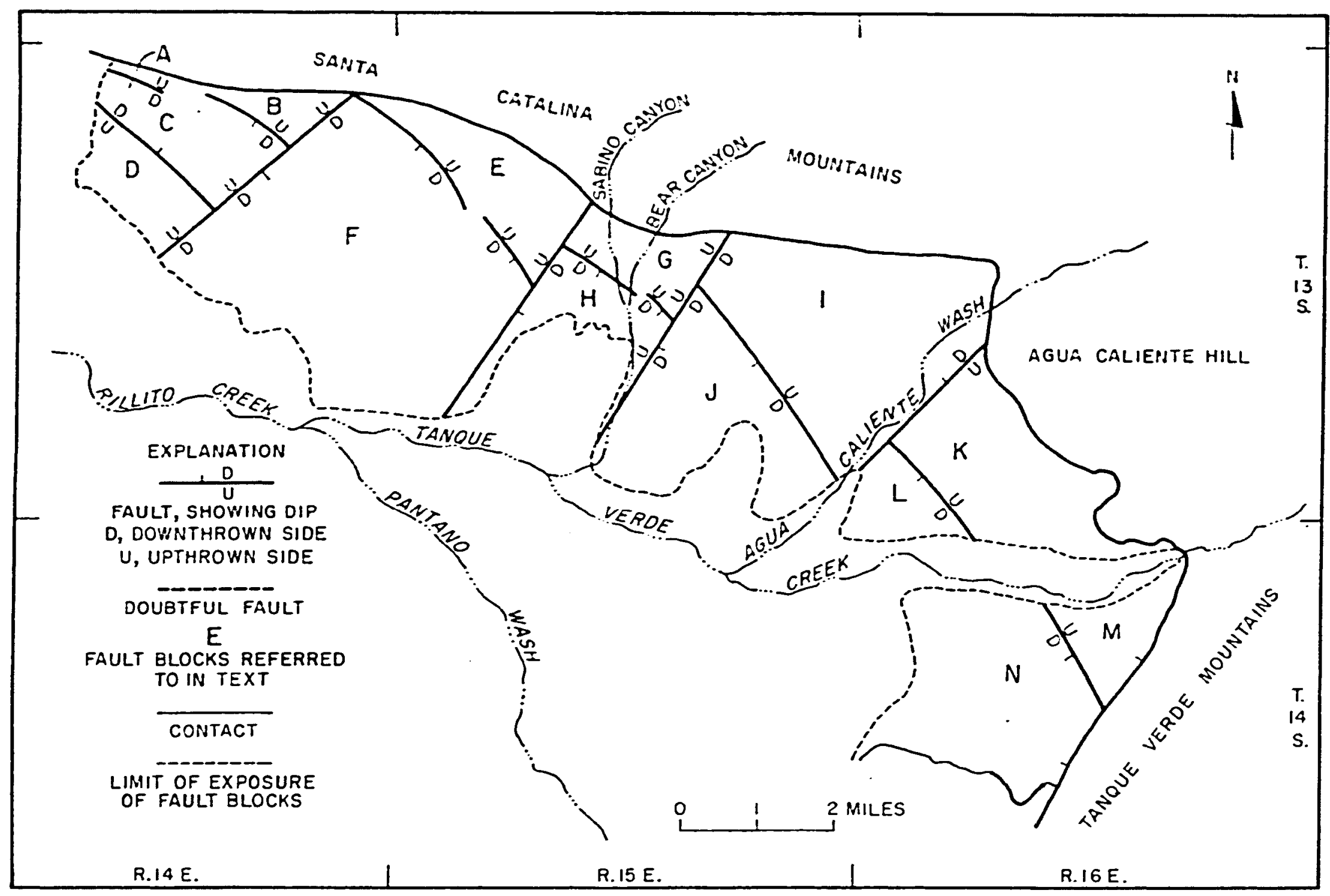

Figure 21.--Index map showing fault blocks. 
The Rillito beds were buried over most of their present extent by younger undeformed deposits, which are referred to in this report as the basin-fill deposits. Subsequent erosion has removed much of the cover of basin-fill deposits and has revealed the underlying Rillito beds along the margins of the Tucson basin. In most of the Tucson basin, however, the basin-fill deposits conceal the Rillito beds.

Along the margins of the basin, water wells that tap the Rillito beds generally have much lower specific capacities than wells that yield water from the basin-fill deposits, thus indicating that the basin-fill deposits are more permeable than the Rillito beds. The ability to distinguish between the basin-fill deposits and the Rillito beds in outcrops and well cuttings and the determination of the thickness and areal distribution of these two units are therefore critical to an overall evaluation of the ground-water supplies of the Tucson basin.

\section{Definition and Distribution}

The Rillito beds are here defined as the body of faulted, jointed, and tilted conglomerate, sandstone, and mudstone units that crop out along the northern and eastern margins of the Tucson basin. The major outcrop belt forms an area 1.5 to 3.5 miles wide by 14 miles long that is bounded by the Rillito Creek and Tanque Verde Wash on the south, the Santa Catalina Mountains on the north, Agua Caliente Hill on the east, and Campbell Avenue on the west (pl. 1). A second outcrop area 
covers about 7 square miles and is immediately south of Tanque Verde Wash and west of the Tanque Verde Mountains.

The Rillito beds are the youngest deposits in the Tucson basin that are involved in obvious structural deformation and are angularly and unconformably overlain by all younger deposits. Their base is not exposed or has not been recognized. The name Rillito beds was chosen because their exposures include the same outcrops studied by Voelger (1953) in defining his Rillito Formation.

\section{Previous Work}

Many of the distinguishing characteristics of the Rillito beds have long been known. The unusual composition of the pebbles in these beds has been noted by several workers. Tolman $(1909$, p. 157) stated that the conglomerates "contain fragments of porphyries and lavas which do not appear in place on the south side of the range." Smith (1910, p. 87) stated that "the outcrops near the mountains show very little or no material derived from the Catalina formation, often fifty percent or more is volcanic rocks, while in outcrops more removed from the mountains a small amount of gneiss is present." Moore and others (1941, p. 13) noted that "in the lower part of the formation the pebbles are of limestone, altered gneiss, volcanic rocks, and some quartzites, whereas at higher horizons gneiss similar to that now being eroded from the Santa Catalina Mountains predominates." 
The significance of the presence of these pebbles in the Rillito beds was commented upon by Tolman (1909, p. 157), who stated that the source for these pebbles must have been "entirely. washed away." Smith (1910, p. 87) suggested that "the relation of these deposits to the mountains and the character of their included material point to the conclusion that they were contemporaneous with the mountain uplift, at least in part."

The characteristic structure of the Rillito beds was noted by Smith (1910, p. 87), who commented that "the deposits are broken and tilted, the small outcrops sometimes dipping gently away from the mountains, sometimes sharply in other directions."

Voelger (1953, p. 29-71) made the most detailed study of the pebble composition of these deposits. On the basis of different pebble composition, he recognized four units - the lower, middle, and upper Rillito Formation and the fan deposits. Voelger (1953, p. 39-52) described the lower Rillito Formation as containing pebbles of granite, volcanic rock, limestone, quartzite, and schist but no gneiss. He described the middle Rillito Formation (Voelger, 1953, p. 63-66) as containing the same pebbles as the lower and, also, pebbles of gneiss. The upper Rillito Formation is described as containing the same pebble types as the middle, but limestone pebbles are absent (Voelger, 1953, p. 70-71). The fans are described as consisting dominantly of gneiss pebbles with lesser amounts of quartzite and schist. 
Subdivisions Used in this Report

Voclger's success in subdividing his Rillito Formation into units based on differences in pebble composition led me to attempt to use the same system in subdividing and mapping the sedimentary units exposed along the northern and eastern margins of the basin. The present author has divided the Rillito beds into three types-I, II, and III-based on differences in pebble composition. These three types do not correspond exactly with Voelger's lower, middle, and upper Rillito Formation.

General information on these three types is given below and is summarized on table 5. The arcal distribution of the conglomerate, sandstone, and mudstone is generalized on figure 22.

\section{Type I}

The type I Rillito beds consist of red to light-gray, firmly to very firmly cemented, interbedded conglomerate, sandstone, and mudstone. Beds of massive gypsum are interbedded with the mudstone in the SW-1/4NE-1/4SW-1/4 sec. 4, T. 13 S., R. 14 E. (fig. 23A). Locally (fig. 21, block M), the type I Rillito beds include light-gray (10YR 7/1) to dark-gray (5YR 4/1) sedimentary breccia, several 3inch beds of mud-cracked limestone, and 6-foot beds of white volcanic ash. 
TABLE 5

SUMMARY OF THE LITHOLOGY OF THE FALLT BLOCKS

\begin{tabular}{|c|c|c|c|c|c|c|}
\hline $\begin{array}{l}\text { FAULT } \\
\text { BLOCK }\end{array}$ & TYPE & LITHOLOGY & COL.OR & CEMENTATION & $\begin{array}{l}\text { MAXIXIUM } \\
\text { PARTICLE } \\
\text { STZE } \\
\end{array}$ & $\begin{array}{c}\text { STREAM } \\
\text { DIRECTION }\end{array}$ \\
\hline$A$ & I & $\begin{array}{l}\text { Sandy conglomerate } \\
\text { and interbedded } \\
\text { sandstone }\end{array}$ & $\begin{array}{l}\text { Pale red }(5 \mathrm{R} 6 / 2) \\
\because \text { eari red }(5 \mathrm{R} 4 / 2)\end{array}$ & Firni & 3 iec: & $\begin{array}{l}\text { Betweer: } \\
\text { northwest } \\
\text { snd } \\
\text { southwest }\end{array}$ \\
\hline B & I & $\begin{array}{l}\text { Congiomerate. } \\
\text { sandstone, and } \\
\text { mudstone }\end{array}$ & $\begin{array}{l}\text { Pa!e red (:YR 6/2) } \\
\text { to redd:sh bro } \because n \\
\{\mathrm{YR} \equiv / 3)\end{array}$ & $\begin{array}{l}\text { Firn to } \\
\text { very } \operatorname{lirm}\end{array}$ & 2 fect & $\begin{array}{l}\text { West to } \\
\text { southinest }\end{array}$ \\
\hline \multirow{3}{*}{ C } & II & Conglomerate & $\begin{array}{l}\text { Pale red (10R 6/2), } \\
\text { pintish gray (jYR T/2) }\end{array}$ & Noderate & \multirow[b]{2}{*}{ 3. 5 fect } & \\
\hline & I & $\begin{array}{l}\text { Mudstone, sand- } \\
\text { sione, and } \\
\text { gypsum }\end{array}$ & $\begin{array}{l}\text { Pink (5YR T/3), pin's- } \\
\text { ish gray }(5 Y R \text { 6/2), } \\
\text { reddish brown } \\
(5 Y R 5 / 3)\end{array}$ & $\begin{array}{l}\text { Hoderate to } \\
\text { firm }\end{array}$ & & \\
\hline & III & Conglomerate & Light gray (iOYR T/2) & Firm & & $\begin{array}{l}\text { S. } 60^{\circ}: \mathrm{Y}^{-}- \\
\text {S. } 60^{\circ} \mathrm{E} .\end{array}$ \\
\hline & & Conglomerate & Light red (10R 6/6) & & & Irest to \\
\hline $\mathrm{D}$ & I & $\begin{array}{l}\text { Sandstone and } \\
\text { muds tone }\end{array}$ & Pale red $(10 \mathrm{R} 6 / 2)$ & Firm & 3 feret & southwest \\
\hline \multirow[b]{2}{*}{$\mathrm{E}$} & 1 & $\begin{array}{l}\text { Conglomerate, } \\
\text { sandstone, and }\end{array}$ & $\begin{array}{l}\text { Dark reddish gray } \\
(10 \mathrm{R} 4 / 1)\end{array}$ & Firm & 3 fect & \\
\hline & $\amalg$ & $\begin{array}{l}\text { mudstone } \\
\text { Conglomeratc and } \\
\text { minor sandstone }\end{array}$ & Pale red (10R 6/2) & Firm & 2 fect & $\begin{array}{l}\text { South to } \\
\text { soutin- } \\
\text { southwest }\end{array}$ \\
\hline
\end{tabular}


TABIES $\overline{5}-$ Continued

\begin{tabular}{|c|c|c|c|c|c|c|}
\hline $\begin{array}{l}\text { FALLTT } \\
\text { BLOCK }\end{array}$ & TYPE & LTIIOLOGY & COI.OR & CEMENTATION & $\begin{array}{l}\text { MAYINUW } \\
\text { PARTICLE } \\
\text { SIZE }\end{array}$ & $\begin{array}{r}\text { STREAM } \\
\text { DIRECTIOS }\end{array}$ \\
\hline \multirow{2}{*}{$\begin{array}{l}F \\
\text { and } \\
H\end{array}$} & III & $\begin{array}{l}\text { Sandstone and } \\
\text { conglome:rite }\end{array}$ & $\begin{array}{l}\text { White (10YR } 8 / 1 \text {, } \\
\text { lOYR } 8 / 2) \text {, light graj } \\
(10 Y R T / 1) \text { pinkish } \\
\text { gray }(7.5 Y R \text { T/2. } \\
\text { T.JYR } 6 / 2) \\
\end{array}$ & $\begin{array}{l}\text { Weak to } \\
\text { sir:n }\end{array}$ & & South \\
\hline & $\Pi$ & $\begin{array}{l}\text { Conglomerate } \\
\text { and sandstone } \\
\text { (reworked type I) }\end{array}$ & $\begin{array}{l}\text { Pinkish gray (5YR } 6 / 2 \text {, } \\
\text { 5YR } 6 / 3), \text { reddish } \\
\text { grav }(5 Y R J / 2) \\
\end{array}$ & Moderate & & \\
\hline $\bar{G}$ & I & Conglomerate & $\begin{array}{l}\text { Light reddish brown } \\
\text { (5YR } 6 / 3)\end{array}$ & Firm & 6 inches & Southwest \\
\hline \multirow[t]{2}{*}{ I } & II & $\begin{array}{l}\text { Conglomerate } \\
\text { and sandstone }\end{array}$ & Pale red (2.5YR 6/2) & Firm & 10 inches & $\begin{array}{l}\text { West- } \\
\text { northwest } \\
\text { to west- } \\
\text { southwest } \\
\end{array}$ \\
\hline & I & $\begin{array}{l}\text { Sandstone and } \\
\text { mudstone } \\
\end{array}$ & $\begin{array}{r}\text { Light gray (10YR } 7 / 1), \\
\text { weak red }(2.5 \text { Y } 5 / 2) \\
\end{array}$ & Firm & & \\
\hline $\mathrm{J}$ & III & $\begin{array}{l}\text { Conglomerate, } \\
\text { sandstone, and } \\
\text { minor ash } \\
\end{array}$ & $\begin{array}{l}\text { Light gray (10YR } 7 / 2) \text {. } \\
\text { pinkish gray } \\
(7.5 Y R 6 / 2) \\
\end{array}$ & $\begin{array}{l}\text { Weak to } \\
\text { firm }\end{array}$ & 1 foot & $\begin{array}{l}\text { West to } \\
\text { southwest }\end{array}$ \\
\hline $\mathrm{K}$ & $I$ & $\begin{array}{l}\text { Miudstone, } \\
\text { sandstone, and } \\
\text { conglomerate }\end{array}$ & $\begin{array}{l}\text { Pinkish gray (5YR } 7 / 2, \\
5 Y R 6 / 2) \text {, reddish } \\
\text { gray }(5 R 6 / 1) \text {, light } \\
\text { reddish brown } \\
(5 Y R 6 / 3) \text {, weak red } \\
(2.5 Y R 4 / 2) \text {, dusky } \\
\text { red }(2.5 Y R 3 / 2) \\
\end{array}$ & Firm & 1 foot & \\
\hline
\end{tabular}


TAELE $\equiv-C o n t i n u e d$

\begin{tabular}{|c|c|c|c|c|c|c|}
\hline $\begin{array}{l}\text { FALLT } \\
\text { BLOCK }\end{array}$ & TYPE & LITHOLOGY & COLOR & CENENTATTON & $\begin{array}{c}\text { MAIITCNI } \\
\text { PARTICLE } \\
\text { SIZE } \\
\end{array}$ & $\begin{array}{c}\text { STREAM } \\
\text { DIRECTION }\end{array}$ \\
\hline L & I & $\begin{array}{l}\text { Conglomerate. } \\
\text { mudstone, and } \\
\text { sandstone }\end{array}$ & $\begin{array}{l}\text { Lisht reddist brown } \\
(I Y \mathrm{P} 6 / 3)\end{array}$ & Firm & 6 inches & \\
\hline $\mathrm{M}$ & $i$ & $\begin{array}{l}\text { Mudstone, sard- } \\
\text { stone, breccia. } \\
\text { conglomerate. } \\
\text { minor limestone, } \\
\text { and ash }\end{array}$ & $\begin{array}{l}\text { Light gray (10YR } 7 / 1) \text {. } \\
\text { minkish g:ay } \\
\text { (i. 5YR } 6 / 2) \text {. dark } \\
\text { gay }(5 Y \mathrm{Y} \div / 1)\end{array}$ & Firm & & West \\
\hline $\mathrm{x}$ & II & $\begin{array}{l}\text { Conglomerate } \\
\text { and sandstone }\end{array}$ & $\begin{array}{l}\text { Ligint gray (10YR } 7 / 2) \text {, } \\
\text { pinkish white } \\
\text { (7. 5YR } 8 / 2) . \text { pint- } \\
\text { ish gray }(7.5 Y \text { Y } 7 / 2)\end{array}$ & Moderate & & \\
\hline
\end{tabular}




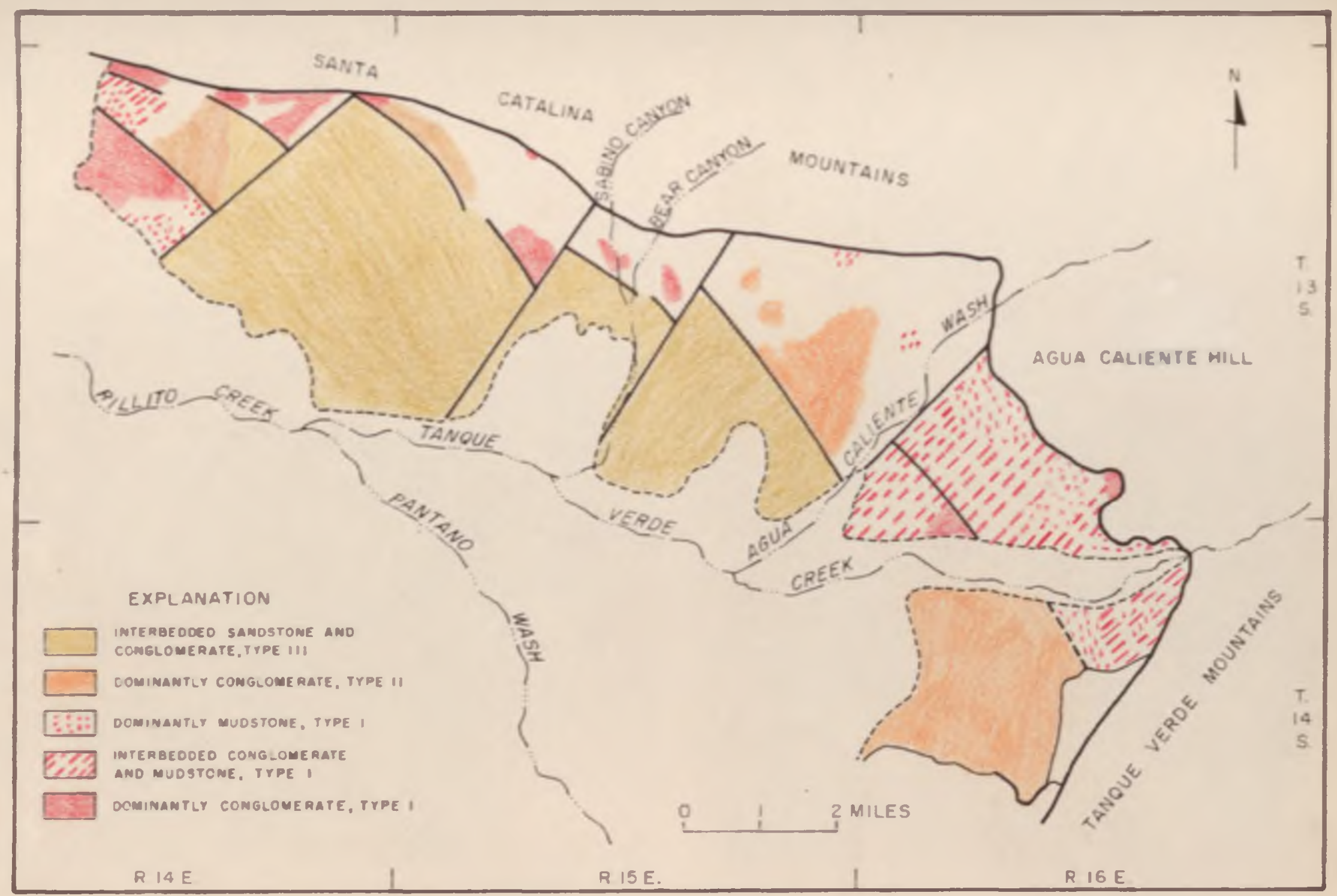

Figure 22. - Areal distribution of conglomerate, sandstone, and mudstone of the Rillito beds. 


\section{FIGURE 23}

TYPE I RILLITO BEDS

\section{A.}

Beds of massive gypsum interbedded with type I mudstone of block C. Exposure is in the $S W-1 / 4 \mathrm{NE}-1 / 4 \mathrm{SW}-1 / 4$ sec. 4, T. $13 \mathrm{~S}$, , R. $14 \mathrm{E}$.

B.

Exposure of type I conglomerate of block D. Here, it consists of alternating layers of pale-red (5R 6/2) and moderate-reddishorange (10R 6/6) conglomerate. 

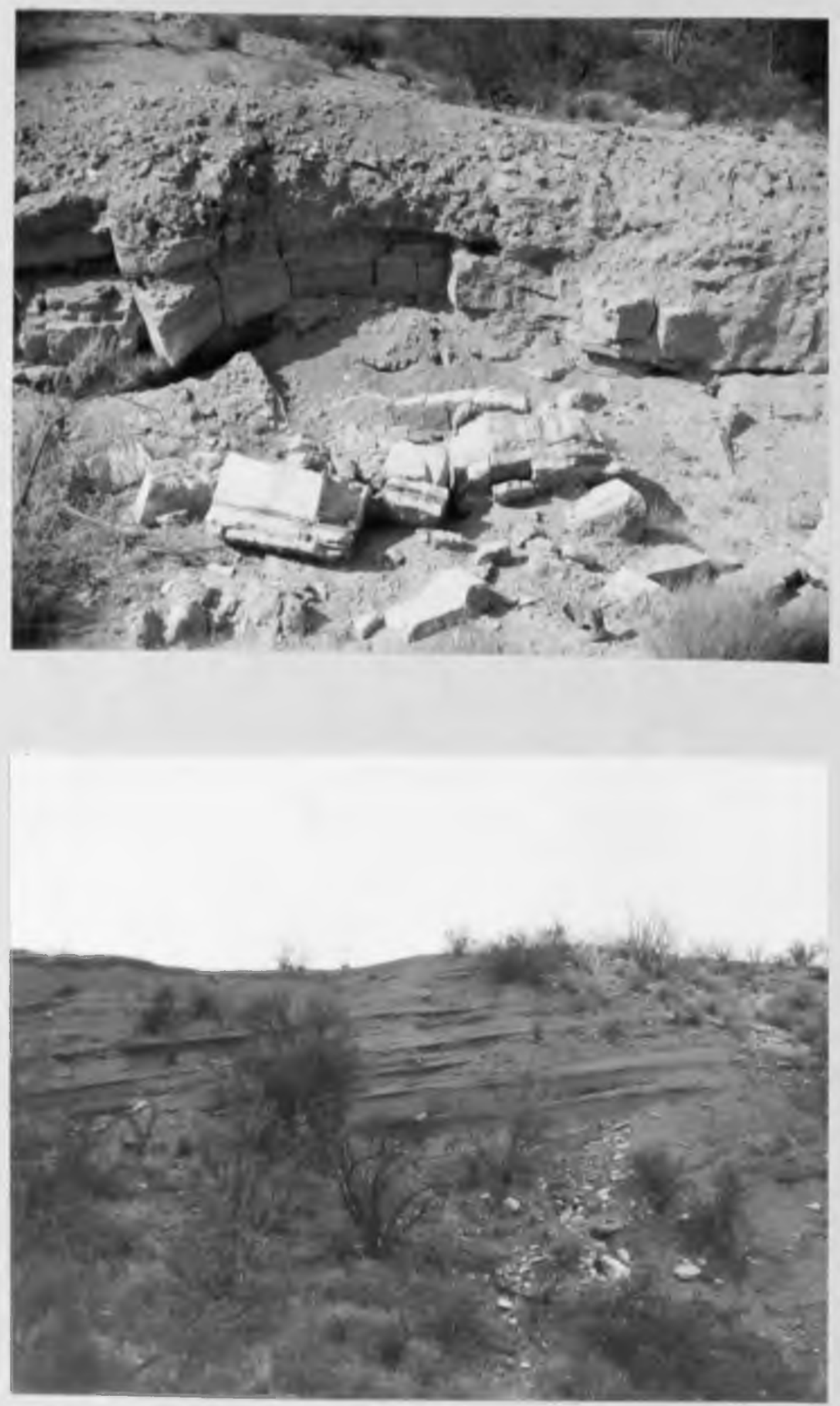
A distinguishing characteristic of the pebble counts (table 6) made at outcrops of the type I Rillito beds is the low percentage of pebbles of Catalina Gneiss. Pebbles of volcanic rock, pink granite, limestone, and quartzite are the dominant types. The sedimentary breccia in block $M$ is composed almost entirely of angular fragments of gray aphanitic volcanic rock.

The type I exposures of block $D$ are characterized by alternating layers of moderate-reddish-orange (10R 6/6) and pale-red (5R 6/2) conglomerate (fig. 23B). Two distinct colors of type I deposits also are present in block M. Light-gray (10YR 7/1) to dark-gray (5YR 4/1) conglomerate, breccia, sandstone, and mudstone are interbedded with pinkish-gray (7.5YR 6/2) conglomerate, sandstone, and mudstone. The light- to dark-gray layers derive their color from their high content of fragments of gray volcanic rocks. The pinkish-gray layers derive their color from a more varied collection of pebble types, including limestone, quartzite, pink granite, and volcanic rocks.

Measurements of pebble imbrication and crossbedding indicate the type I conglomerate was deposited by streams flowing in northwesterly, westerly, and southwesterly directions.

\section{Type II}

The type II Rillito beds consist of moderately to firmly cemented conglomerate with lesser amounts of interbedded sandstone 
TABLE 6

PEBBLE COUNTS OF TYPE I OF THE RILLITO BEDS

\begin{tabular}{|c|c|c|c|c|c|c|c|c|c|c|c|c|}
\hline Block & Number & Location & $\begin{array}{c}\text { Vol- } \\
\text { canic } \\
\text { rocks }\end{array}$ & $\begin{array}{c}\text { Pink } \\
\text { granite }\end{array}$ & $\begin{array}{l}\text { White } \\
\text { granite }\end{array}$ & $\begin{array}{l}\text { Lime- } \\
\text { stone }\end{array}$ & Quartzite & $\begin{array}{l}\text { Con- } \\
\text { glon- } \\
\text { erate } \\
\end{array}$ & $\begin{array}{l}\text { Sand- } \\
\text { stone }\end{array}$ & Schist & Gneiss & $\begin{array}{l}\text { Miscel- } \\
\text { laneous }\end{array}$ \\
\hline & & $\begin{array}{c}(D-13-14) \\
4 a b b\end{array}$ & 50 & 20 & 0 & 9 & 13 & 2 & 4 & 0 & 0 & 2 \\
\hline $\begin{array}{l}A \\
A\end{array}$ & $\begin{array}{l}1 \\
2\end{array}$ & $4 a b b a$ & 23 & 35 & 0 & 13 & 21 & 0 & 6 & 0 & 0 & 2 \\
\hline B & 3 & $\begin{array}{c}(D-13-14) \\
2 b c c\end{array}$ & 29 & 8 & 0 & 16 & 37 & 0 & 6 & 4 & 0 & 0 \\
\hline$B$ & 4 & $2 c d a b$ & 36 & 2 & 5 & 13 & 18 & 1 & 9 & 10 & 5 & 1 \\
\hline $\mathrm{B}$ & 5 & $2 b d d b$ & 43 & 1 & 4 & 5 & 16 & 2 & 4 & 20 & 5 & 0 \\
\hline $\mathrm{B}$ & 6 & 2bdd & 44 & 0 & 2 & 8 & 25 & 0 & 2 & 14 & 5 & 0 \\
\hline B & 7 & $3 b d a d$ & 31 & 17 & 0 & 22 & 27 & 0 & 3 & 0 & 0 & 0 \\
\hline C & 8 & $\begin{array}{c}(\mathrm{D}-13-14) \\
3 \mathrm{dbba}\end{array}$ & 38 & 13 & 0 & 5 & 18 & 1 & 1 & 12 & 11 & 1 \\
\hline C & 9 & $4 \mathrm{bdcc}$ & 48 & 7 & 3 & 8 & 15 & 4 & 0 & 4 & 11 & 0 \\
\hline C & 10 & $4 b d d b$ & 38 & 10 & 5 & 6 . & 20 & 5 & 7 & 7 & 2 & 0 \\
\hline $\mathrm{C}$ & 11 & 4caaa & 48 & 4 & 6 & 5 & 13 & 0 & 2 & 4 & 13 & 5 \\
\hline & & $\begin{array}{c}(D-13-14) \\
4 c c d c\end{array}$ & 28 & 15 & 9 & 10 & 12 & 2 & 9 & 4 & 0 & 11 \\
\hline $\begin{array}{l}D \\
D\end{array}$ & 12 & $\begin{array}{l}4 \mathrm{ccac} \\
8 \text { adaa }\end{array}$ & $\begin{array}{l}20 \\
35\end{array}$ & 17 & 0 & 15 & 20 & 4 & 3 & 3 & 1 & 2 \\
\hline $\mathrm{D}$ & 14 & 9dddd & 44 & 12 & 0 & 12 & 21 & 0 & 7 & 3 & 1 & 0 \\
\hline $\mathrm{D}$ & 15 & $9 \mathrm{cbca}$ & 30 & 22 & 0 & 13 & 20 & 4 & 9 & 2 & 0 & 0 \\
\hline D & 16 & $9 \mathrm{bbba}$ & 39 & 23 & 0 & 8 & 13 & 0 & 6 & 10 & 0 & 1 \\
\hline
\end{tabular}


TABLE 6 - Cuntinued

\begin{tabular}{|c|c|c|c|c|c|c|c|c|c|c|c|c|}
\hline Block & Number & iocation & $\begin{array}{l}\text { Vol- } \\
\text { canic } \\
\text { ruation }\end{array}$ & $\begin{array}{c}\text { Pink } \\
\text { grante }\end{array}$ & $\begin{array}{l}\text { Hbate } \\
\text { granite }\end{array}$ & $\begin{array}{l}\text { ininc- } \\
\text { stione }\end{array}$ & Quisizite & $\begin{array}{l}\text { Con- } \\
\text { glnm- } \\
\text { crite } \\
\end{array}$ & $\begin{array}{l}\text { Sand- } \\
\text { stone }\end{array}$ & Schist & Concisi & $\begin{array}{l}\text { Misce!- } \\
\text { iancous }\end{array}$ \\
\hline & & (D-13-14) & 63 & 16 & 0 & 4 & 10 & 3 & 4 & 0 & 0 & 0 \\
\hline $\begin{array}{l}\mathrm{D} \\
\mathrm{D}\end{array}$ & $\begin{array}{l}17 \\
18\end{array}$ & l6bda & $\begin{array}{l}03 \\
60\end{array}$ & 2 & 0 & 2 & 10 & 2 & 22 & 2 & 0 & 0 \\
\hline D & 19 & 16 baaa & 38 & 15 & 1 & 11 & 20 & 3 & 7 & 0 & 0 & 5 \\
\hline D & 20 & $16 \mathrm{dbab}$ & 54 & 10 & 0 & 12 & 24 & 0 & 0 & 0 & 0 & 0 \\
\hline & & $(D-13-14)$ & & & & & & 5 & 0 & 21 & 17 & 1 \\
\hline $\mathbf{E}$ & 21 & ladcb & 14 & 3 & $\begin{array}{l}0 \\
4\end{array}$ & $\begin{array}{r}8 \\
16\end{array}$ & $\begin{array}{l}31 \\
20\end{array}$ & $\begin{array}{l}0 \\
0\end{array}$ & 4 & 7 & 10 & 0 \\
\hline $\mathbf{E}$ & 22 & lacd & 32 & 7 & $\begin{array}{l}4 \\
2\end{array}$ & $\begin{array}{l}10 \\
12\end{array}$ & $\begin{array}{l}20 \\
17\end{array}$ & 4 & 3 & 21 & 4 & 2 \\
\hline $\mathrm{E}$ & 23 & $\begin{array}{c}\operatorname{lacc} \\
(D-13-15)\end{array}$ & 30 & 5 & 2 & 12 & 17 & 4 & 3 & 21 & 4 & 2 \\
\hline$E$ & 24 & $8 a b b d$ & 53 & 0 & 0 & 8 & 19 & 0 & 20 & 0 & 0 & 0 \\
\hline $\mathrm{E}$ & 25 & 17 daab & 30 & 1 & 0 & 33 & 30 & 5 & 0 & 0 & 1 & 0 \\
\hline & & $(D-13-15)$ & & & 0 & 20 & 26 & 0 & 8 & 2 & 2 & 4 \\
\hline G & 26 & $15 \mathrm{cdb}$ & 36 & $\begin{array}{l}2 \\
3\end{array}$ & $\begin{array}{l}0 \\
0\end{array}$ & 25 & 19 & 0 & 10 & 2 & 3 & 2 \\
\hline $\begin{array}{l}\text { G } \\
\text { G }\end{array}$ & 27 & $16 a c c b$ & 36 & 3 & 0 & 32 & 19 & 0 & 11 & 0 & 5 & 0 \\
\hline G & 28 & $16 \mathrm{ddb}$ & 27 & 6 & & & & & & & & \\
\hline $\mathrm{K}$ & 29 & $\begin{array}{c}(D-13-16) \\
33 \mathrm{cbbc}\end{array}$ & 72 & 23 & 0 & 1 & 0 & 0 & 4 & 0 & 0 & 0 \\
\hline $\mathrm{K}$ & 30 & $33 a c b c$ & 88 & 11 & 0 & 0 & 0 & 0 & 1 & 0 & 0 & 0 \\
\hline $\mathrm{K}$ & 31 & $32 \mathrm{cdcb}$ & 85 & 14 & 0 & 0 & 1 & 0 & 0 & 0 & 0 & 0 \\
\hline $\mathrm{K}$ & 32 & 32abcd & 50 & 40 & 0 & 2 & 3 & 0 & 0 & 0 & 0 & 5 \\
\hline $\mathrm{K}$ & 33. & $31 \mathrm{aabb}$ & 76 & 8 & 0 & 0 & 0 & 0 & 10 & 0 & 0 & 6 \\
\hline
\end{tabular}


TABLE 6 -Continued

\begin{tabular}{|c|c|c|c|c|c|c|c|c|c|c|c|c|}
\hline Block & Number & Location & $\begin{array}{l}\text { Vol- } \\
\text { canic } \\
\text { rockis }\end{array}$ & $\begin{array}{c}\text { Pink } \\
\text { granite }\end{array}$ & $\begin{array}{c}\text { White } \\
\text { granite }\end{array}$ & $\begin{array}{l}\text { Lime- } \\
\text { stone }\end{array}$ & Quartzite & $\begin{array}{l}\text { Con- } \\
\text { glom- } \\
\text { erste } \\
\end{array}$ & $\begin{array}{l}\text { Sand- } \\
\text { stune }\end{array}$ & Schist & Cineiss & $\begin{array}{l}\text { Miscel- } \\
\text { laneous }\end{array}$ \\
\hline $\mathrm{K}$ & 34 & $\begin{array}{c}(D-13-16) \\
29 c \text { dad } \\
(D-14-16)\end{array}$ & 75 & 25 & 0 & 0 & 0 & 0 & 0 & 0 & 0 & 0 \\
\hline K & 35 & 5aada & 68 & 27 & 0 & 1 & 0 & 0 & 4 & 0 & 0 & 0 \\
\hline $\mathrm{L}$ & 36 & $\begin{array}{c}(\mathrm{D}-13-16) \\
32 \mathrm{ccc}\end{array}$ & 43 & 3 & 13 & 5 & 11 & 0 & 9 & 1 & 12 & 3 \\
\hline $\mathrm{L}$ & 37 & 31 dcaa & 32 & 0 & 30 & 4 & 14 & 0 & 2 & 4 & 14 & 0 \\
\hline$L$ & 38 & $31 \mathrm{ccdd}$ & 50 & 18 & 16 & 2 & 10 & 0 & 2 & 2 & 0 & 0 \\
\hline $\mathrm{L}$ & 39 & 31 acdd & 46 & 16 & 0 & 0 & 8 & 0 & 16 & 2 & 12 & 0 \\
\hline $\mathrm{L}$ & 40 & $31 \mathrm{dddb}$ & 52 & 29 & 4 & 3 & 8 & 0 & 2 & 1 & 0 & 1 \\
\hline L & 41 & 31 abaa & 44 & 21 & 7 & 9 & 0 & 0 & 18 & 0 & 0 & 1 \\
\hline L & 42 & $31 \mathrm{abcc}$ & 52 & 28 & 2 & 2 & 0 & 0 & 4 & 0 & 8 & 4 \\
\hline $\mathbf{M}$ & 43 & $\begin{array}{c}(D-14-16) \\
9 \text { caaa }\end{array}$ & 30 & 29 & 0 & 6 & 18 & 0 & 4 & 4 & 7 & 2 \\
\hline IVI & 44 & $9 c d d$ & 27 & 23 & 0 & 9 & 11 & 0 & 8 & 4 & 16 & 2 \\
\hline $\mathrm{M}$ & 45 & $16 \mathrm{dac}$ & 12 & 29 & 0 & 35 & 15 & 0 & 7 & 2 & 0 & 0 \\
\hline M & 46 & $10 b d b$ & 40 & 32 & 0 & 14 & 7 & 0 & 5 & 0 & 0 & 2 \\
\hline$M$ & 47 & $10 \mathrm{bcdd}$ & 42 & 32 & 0 & 8 & 13 & 0 & 5 & 0 & 0 & 0 \\
\hline$M$ & 48 & $10 c a b c$ & 70 & 22 & 0 & 0 & 5 & 0 & 1 & 0 & 2 & 0 \\
\hline
\end{tabular}


(fig. 24A). Mudstone is not present. The conglomerate varies in color from pale red to pinkish white. Along the eastern edge of block $\mathrm{C}$, type II conglomerate is interbedded with type III conglomerate (fig. 24B). The type II conglomerate contains the same types of pebbles as type I, but the percentage of pebbles of Catalina Gneiss is generally greater (table $\eta$ ).

Type III

The type III Rillito beds consist mainly of light-gray to pinkishgray sandy conglomerate and interbedded sandstone (fig. 25A). Beds of white volcanic ash are interbedded with the conglomerate at several localities. Locally, the sandstone and conglomerate are firmly cemented and form concretelike ledges (fig. 25B); elsewhere, they are loosely cemented (fig. 26A). The type III conglomerate is distinguished from that of types I and II by the great dominance of gneiss pebbles over all other types (table 8). The pebble counts show an average gneiss pebble content of 68 percent, and it ranges from 30 to 90 percent. In addition to the gneiss pebbles, schist is common, followed in abundance by volcanic rocks and quartzite; limestone pebbles are rare. The presence of rotten shells of limestone pebbles indicates that they have been dissolved out of many of the exposures of the type III Rillito beds.

Many of the beds of sandstone are characterized by a knobby upper and lower surface (fig. 26B). These knobs reflect differential 
FIGURE 24

TYPE II RILLITO BEDS

(Photo for fig. 24B by J. F. Lance)

A.

The "Whaleback"一a hill composed of type II conglomerate in block E. The cementation, bedding, and dip are typical of the deposits in block $\mathrm{E}$.

B.

Layer of type III conglomerate enclosed between layers of type II conglomerate. Photo taken in Pontatoc Wash, eastern part of block C. 

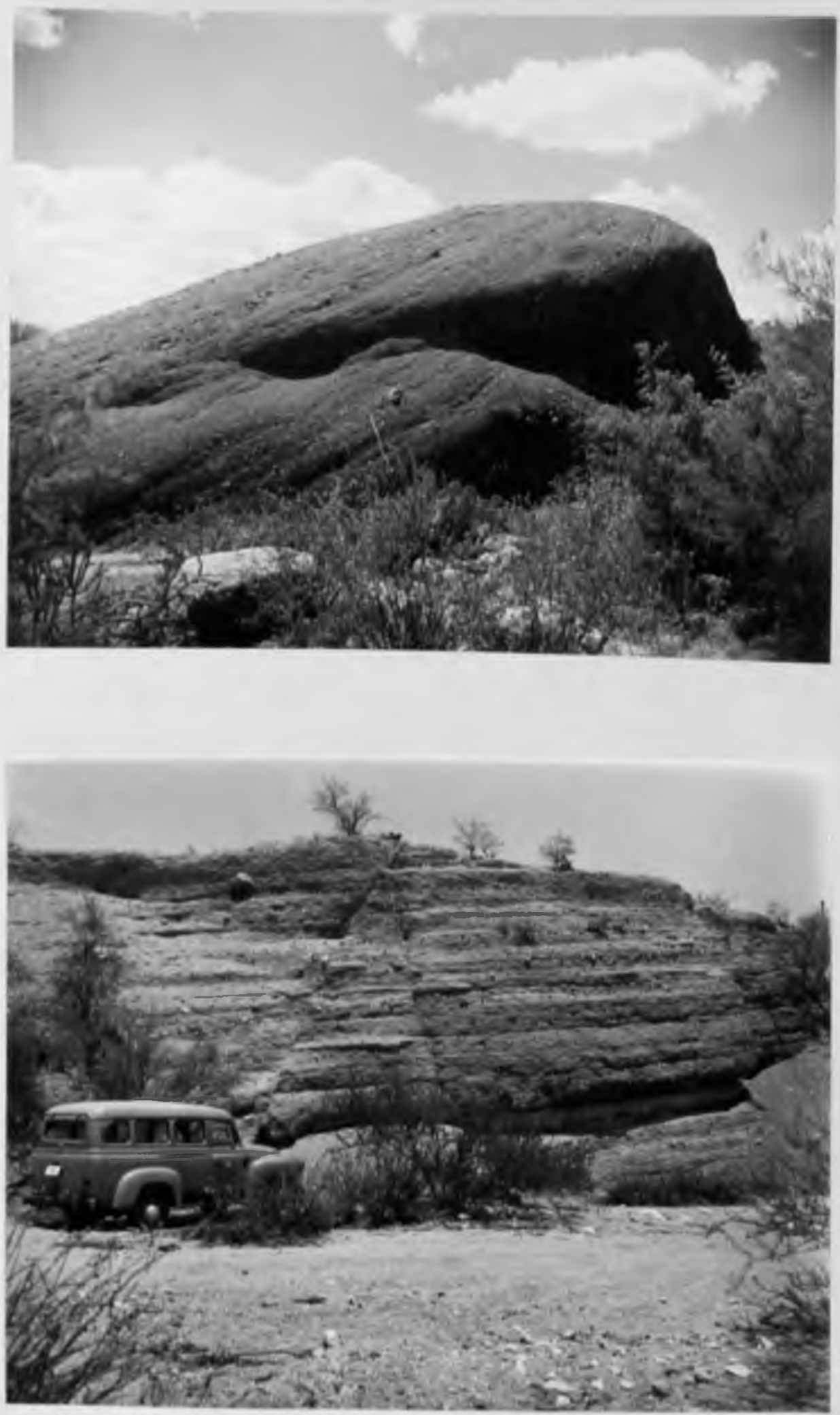
TABLE 7

PEBBLE COLNTS OF TYPE II OF THE RILLITO BEDS

\begin{tabular}{|c|c|c|c|c|c|c|c|c|c|c|c|c|}
\hline Blnck & Ninaber & Location & $\begin{array}{l}\text { Yul- } \\
\text { canic } \\
\text { roncks }\end{array}$ & $\begin{array}{c}\text { Inlat: } \\
\text { gra:::tc }\end{array}$ & $\begin{array}{l}\text { Histe } \\
\text { granite }\end{array}$ & $\begin{array}{l}\text { Lime- } \\
\text { stone }\end{array}$ & Quartaite & $\begin{array}{l}\text { Cim- } \\
\text { slowi- } \\
\text { eraic }\end{array}$ & $\begin{array}{l}\text { Siand - } \\
\text { Stone }\end{array}$ & Schist & Grociss & $\begin{array}{l}\text { Misscel- } \\
\text { laneous }\end{array}$ \\
\hline & & $(D-13-14)$ & & & & & & & & & & \\
\hline C & 49 & $10 \mathrm{bcbc}$ & 28 & 3 & 13 & 2 & 12 & 0 & 2 & 16 & 20 & 4 \\
\hline C & 50 & $10 \mathrm{bccd}$ & 30 & 2 & 7 & 11 & 9 & 0 & 6 & 17 & 15 & 3 \\
\hline C & 51 & $10 a c b c$ & 29 & 5 & 6 & 9 & 15 & 0 & 7 & 12 & 17 & 0 \\
\hline C & 52 & $10 \mathrm{bddc}$ & $\$ 0$ & 9 & 0 & 3 & 7 & 0 & 7 & 13 & 18 & 3 \\
\hline & & $(D-13-15)$ & & 2 & 0 & 16 & 14 & 0 & 3 & 4 & 38 & 7 \\
\hline $\begin{array}{l}E \\
E\end{array}$ & $\begin{array}{l}53 \\
54\end{array}$ & $\begin{array}{l}\text { ocdaa } \\
6 c d c b\end{array}$ & 28 & 6 & 0 & 8 & 12 & 12 & 0 & 12 & 20 & 2 \\
\hline$E$ & 55 & $6 \mathrm{bcbc}$ & 23 & 7 & 3 & 13 & 17 & 6 & 2 & 19 & 10 & 0 \\
\hline $\mathbf{E}$ & 56 & $6 \mathrm{cccb}$ & 35 & 3 & 0 & 0 & 18 & 2 & 11 & 12 & 17 & 2 \\
\hline$E$ & 57 & $7 \mathrm{bddb}$ & 17 & 5 & 0 & 17 & 20 & 0 & 5 & 4 & 31 & 1 \\
\hline$E$ & 58 & 7 dadc & 23 & 2 & 3 & 9 & 17 & 0 & 11 & 10 & 25 & 0 \\
\hline & & $(D-13-15)$ & & & & & & & & 2 & 40 & 0 \\
\hline$F$ & 59 & $17 \mathrm{bca}$ & 43 & 6 & 0 & 0 & 9 & 0 & 0 & 2 & 30 & \\
\hline$F$ & 60 & $17 \mathrm{bca}$ & 32 & 7 & 0 & 0 & 18 & 0 & 2 & 5 & 36 & 0 \\
\hline$I$ & 61 & $\begin{array}{c}(D-13-16) \\
19 b b c d\end{array}$ & 27 & 0 & 0 & 19 & 23 & 0 & 6 & 1 & 24 & 0 \\
\hline & & $(D-13-15)$ & & & & & & & & & & \\
\hline$I$ & 62 & $14 \mathrm{cdd}$ & 14 & 3 & 0 & 26 & 37 & 0 & 0 & 10 & 10 & 0 \\
\hline$I$ & 63 & $23 a a c c$ & 17 & 5 & 0 & 23 & 26 & 0 & 4 & 7 & 10 & 8 \\
\hline
\end{tabular}


TABLE 7 - Continued

\begin{tabular}{|c|c|c|c|c|c|c|c|c|c|c|c|c|}
\hline Binc: & Number & Loration & $\begin{array}{c}\text { Vol- } \\
\text { canic } \\
\text { rusich }\end{array}$ & $\begin{array}{l}\text { Pinh } \\
\text { gramite }\end{array}$ & $\begin{array}{c}\text { White } \\
\text { Granite }\end{array}$ & $\mid \begin{array}{l}\text { Linine- } \\
\text { stone }\end{array}$ & Quartzite & $\begin{array}{l}\text { Con- } \\
\text { gloni- } \\
\text { erate } \\
\end{array}$ & $\begin{array}{l}\text { Sard- } \\
\text { stunc }\end{array}$ & Schist & Gnciss & $\begin{array}{l}\text { Miscel- } \\
\text { laneous }\end{array}$ \\
\hline & & $(D-13-15)$ & & & & & & & & & & \\
\hline I & 64 & 23dabb & 29 & 1 & 0 & 12 & 23 & 0 & 5 & 3 & 24 & 3 \\
\hline I & 65 & 23bac & 30 & 2 & 0 & 12 & 30 & 0 & 4 & 0 & 20 & 2 \\
\hline I & 66 & 23dủaa & 19 & 0 & 0 & 22 & 21 & 0 & 6 & 7 & 23 & 2 \\
\hline I & 67 & 26aaad & 15 & 0 & 0 & 18 & 24 & 0 & 6 & 4 & 33 & 0 \\
\hline I & 68 & $26 a a b c b$ & 24 & 0 & 0 & 27 & 15 & 0 & 5 & 1 & 27 & 1 \\
\hline I & 69 & $25 \mathrm{bbba}$ & 17 & 1 & 0 & 16 & 21 & 0 & 10 & 2 & 32 & 1 \\
\hline & & $(D-14-16)$ & & & & & & & & & & \\
\hline $\mathrm{N}$ & 70 & 7 ddab & 10 & 18 & 0 & 18 & 9 & 0 & 5 & 1 & 38 & 1 \\
\hline $\mathrm{N}$ & 71 & 7 daca & 23 & 30 & 0 & 5 & 16 & 0 & 1 & 3 & 16 & 6 \\
\hline$N$ & 72 & $8 \mathrm{cdcd}$ & 12 & 15 & 0 & 20 & 17 & 0 & 3 & 3 & 24 & 6 \\
\hline $\mathrm{N}$ & 73 & $8 c c a b$ & 9 & 26 & 0 & 17 & 16 & 0 & 8 & 4 & 20 & 0 \\
\hline $\mathbf{N}$ & 74 & $8 a c d a$ & 18 & 14 & 0 & 6 & 14 & 0 & 2 & 12 & 24 & 10 \\
\hline $\mathrm{N}$ & 75 & $8 \mathrm{dccc}$ & 4 & 24 & 0 & 14 & 32 & 0 & 0 & 10 & 12 & 4 \\
\hline $\mathrm{N}$ & 76 & 8dbdd & 31 & 29 & 0 & 14 & 9 & 0 & 2 & 2 & 11 & 2 \\
\hline $\mathrm{N}$ & 7.7 & $17 \mathrm{cda}$ & 26 & 22 & 0 & 3 & 12 & 0 & 5 & 10 & 22 & 0 \\
\hline $\mathrm{N}$ & 78 & $17 \mathrm{caa}$ & 13 & 26 & 0 & 8 & 15 & 0 & 4 & 4 & 30 & 0 \\
\hline $\mathrm{N}$ & 79 & $17 \mathrm{acbb}$ & 6 & 30 & 0 & 22 & 12 & 0 & 2 & 6 & 26 & 2 \\
\hline $\mathrm{N}$ & 80 & $18 \mathrm{cdba}$ & 6 & 15 & 0 & 20 & 27 & 0 & 5 & 10 & 17 & 0 \\
\hline $\mathrm{N}$ & 81 & $18 \mathrm{dcba}$ & 7 & 12 & 0 & 22 & 15 & 0 & 2 & 10 & 28 & 4 \\
\hline$N$ & 82 & $18 \mathrm{acda}$ & 12 & 28 & 0 & 10 & 20 & 0 & 0 & 4 & 26 & 0 \\
\hline $\mathrm{N}$ & 83 & $18 a a b d$ & 7 & 19 & 0 & 20 & 14 & 0 & 1 & 6 & 31 & 2 \\
\hline $\mathrm{N}$ & 84 & $18 \mathrm{ddda}$ & 20 & 23 & 0 & 13 & 21 & 0 & 3 & 8 & 12 & 0 \\
\hline
\end{tabular}


FIGURE 25

TYPE III RILLITO BEDS

A.

Interbedded conglomerate and sandstone of type III south of River Road in block $F$.

B.

Concretelike ledge of type III conglomerate east of Swan Road near the T. V. towers in section 22. 

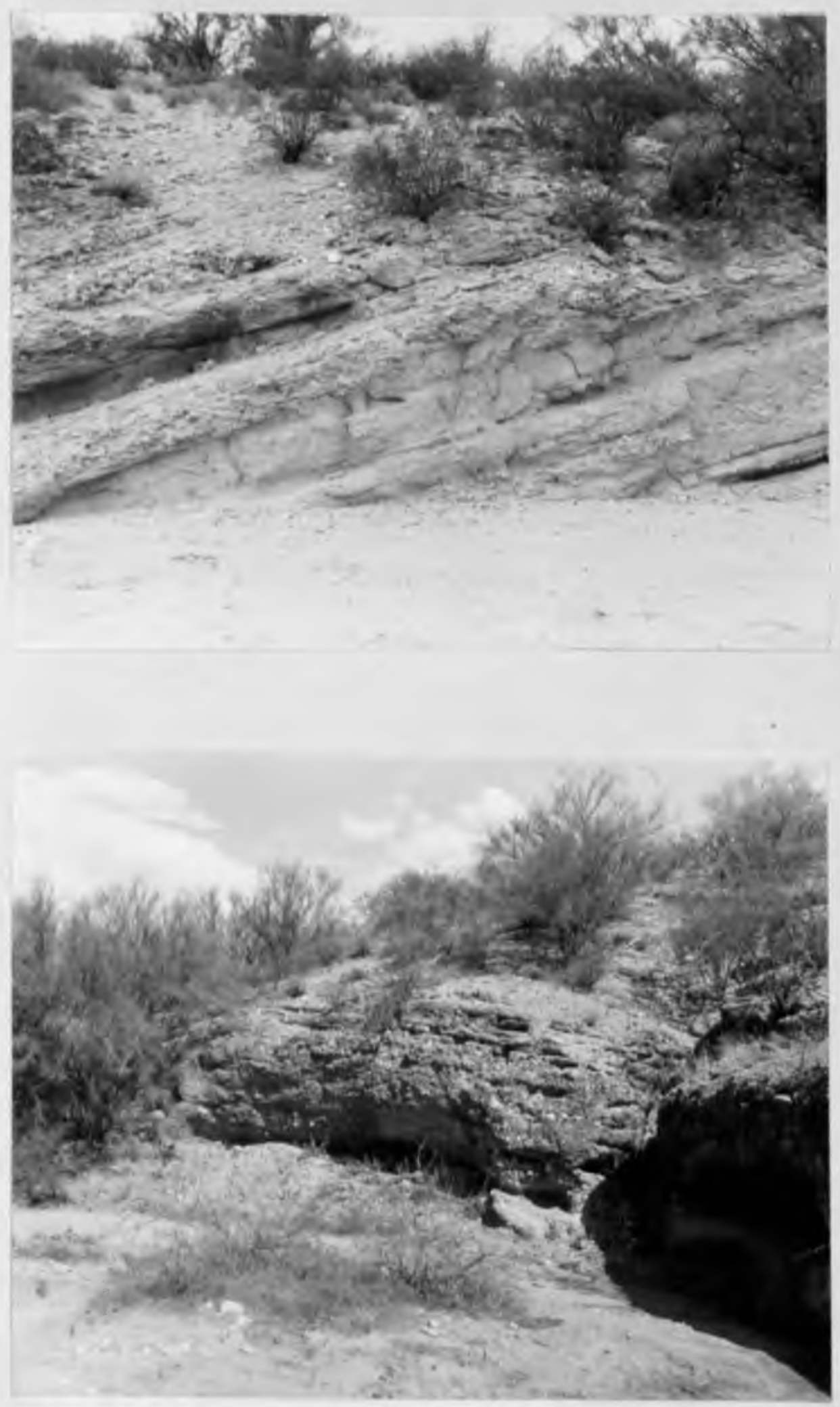
FIGURE 26

TYPE III RILLITO BEDS

A.

Loosely cemented gravel of the type III deposits in block F.

B.

Typical knobby surface of a sandstone bed of the type III deposits. 

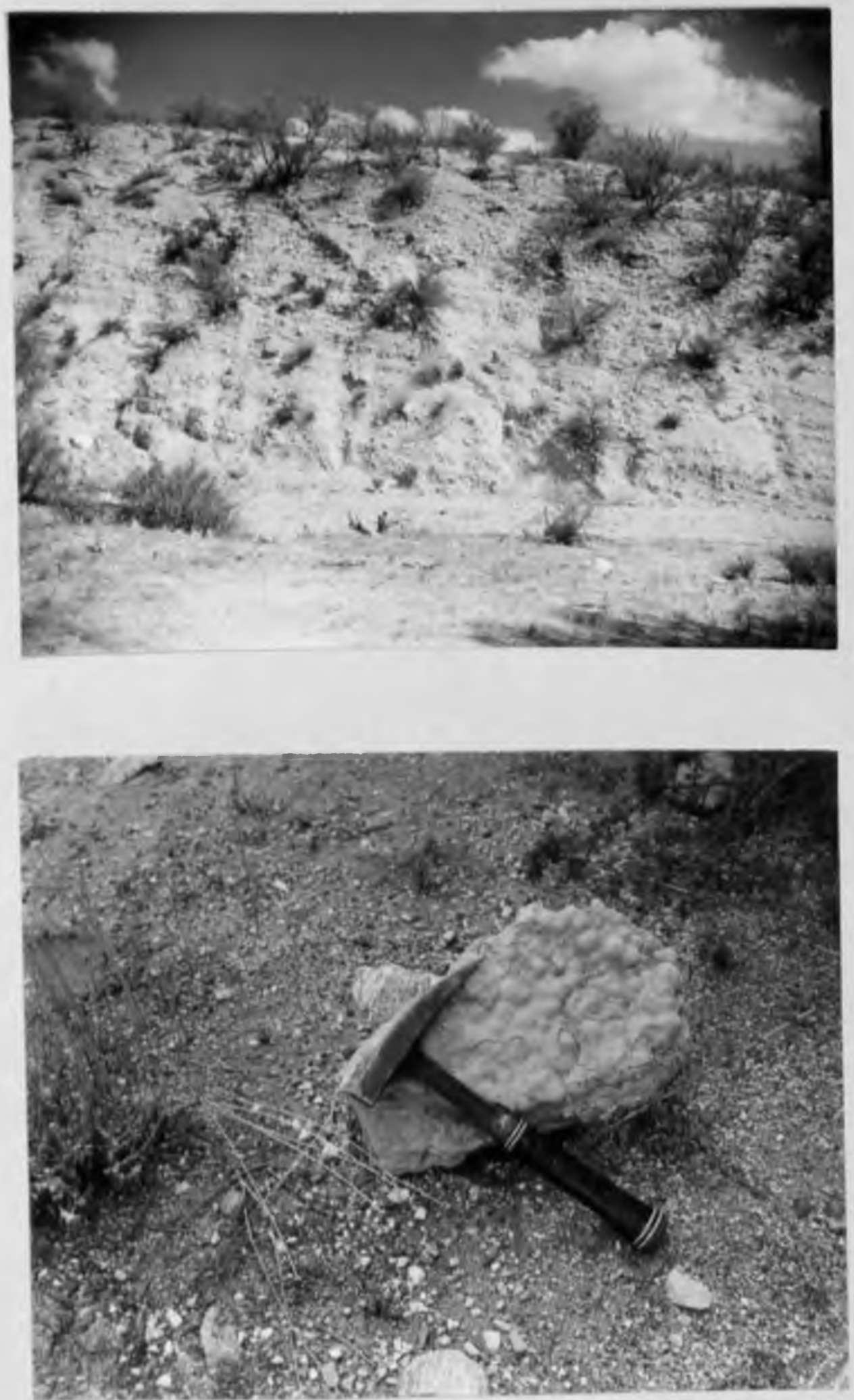
TABLE 8

PEBBLE COUNTS OF TYPE III OF THE RILLITO BEDS

\begin{tabular}{|c|c|c|c|c|c|c|c|c|c|c|c|c|}
\hline Block & Munber & Location & $\begin{array}{l}\text { Vol- } \\
\text { canic } \\
\text { rocks }\end{array}$ & $\begin{array}{c}\text { Prar. } \\
\text { zaraite }\end{array}$ & $\begin{array}{c}\text { ibiate } \\
\text { granite }\end{array}$ & $\begin{array}{l}\text { Eime- } \\
\text { stone }\end{array}$ & Ruartaite & $\begin{array}{l}\text { Con- } \\
\text { slom- } \\
\text { erate }\end{array}$ & $\begin{array}{l}\text { Sond- } \\
\text { Etonise }\end{array}$ & Schist & Gretso & $\begin{array}{l}\text { Miscei- } \\
\text { laneous }\end{array}$ \\
\hline $\mathrm{C}$ & 85 & $\begin{array}{c}(D-13-14) \\
10 a c b c\end{array}$ & 10 & 3 & 14 & 0 & 8 & 0 & 2 & 33 & 30 & 0 \\
\hline C & 86 & 10aaba & 0 & 0 & 0 & 0 & 0 & 0 & 0 & 35 & 65 & 0 \\
\hline$F$ & 87 & $\begin{array}{c}(\mathrm{D}-13-14) \\
12 \mathrm{bacd}\end{array}$ & 6 & 0 & 0 & 0 & 3 & 0 & 0 & 15 & 75 & 1 \\
\hline$F$ & 88 & 13abaa & 10 & 2 & 0 & 0 & 12 & 0 & 0 & 6 & 70 & 0 \\
\hline $\mathbf{F}$ & 89 & $14 \mathrm{cbbb}$ & 1 & 0 & 0 & 0 & $\mathbf{5}$ & 0 & 0 & 38 & 56 & 0 \\
\hline$F$ & 90 & $23 b b b c$ & 2 & 0 & 0 & 2 & 8 & 0 & 1 & 36 & 49 & 2 \\
\hline$F$ & 91 & $\begin{array}{c}25 \mathrm{bcbb} \\
(\mathrm{D}-13-15)\end{array}$ & 25 & 1 & 0 & 0 & 12 & 0 & 0 & 10 & 52 & 0 \\
\hline $\mathbf{F}$ & 92 & $18 \mathrm{bbbb}$ & 16 & 1 & 0 & 0 & 9 & 0 & 1 & 7 & 66 & 0 \\
\hline$F$ & 93 & $18 \mathrm{bbbb}$ & 16 & 5 & 0 & 0 & 6 & 0 & 0 & 14 & 59 & 0 \\
\hline $\mathrm{H}$ & 94 & $\begin{array}{c}(D-13-15) \\
20 a c d b\end{array}$ & 11 & 1 & 0 & 0 & 26 & 0 & 0 & 8 & 49 & 5 \\
\hline$F$ & 95 & $\begin{array}{c}(D-13-15) \\
30 \mathrm{cba}\end{array}$ & 5 & 2 & 0 & 0 . & 6 & 0 & 0 & 16 & 71 & 0 \\
\hline $\mathrm{H}$ & 96 & $\begin{array}{c}(D-13-15) \\
30 \mathrm{dadb}\end{array}$ & $\overline{5}$ & 0 & 0 & 0 & 9 & 0 & 0 & 15 & 67 & 4 \\
\hline
\end{tabular}


TABLE 8 -Continued

\begin{tabular}{|c|c|c|c|c|c|c|c|c|c|c|c|c|}
\hline Block & Number & Location & $\begin{array}{l}\text { Vol- } \\
\text { canic } \\
\text { rocks }\end{array}$ & $\begin{array}{c}\text { Pink } \\
\text { granite }\end{array}$ & $\begin{array}{c}\text { White } \\
\text { granite }\end{array}$ & $\begin{array}{l}\text { Lime- } \\
\text { etone }\end{array}$ & Quartzite & $\begin{array}{l}\text { Con- } \\
\text { glom- } \\
\text { erate }\end{array}$ & $\begin{array}{l}\text { Sand- } \\
\text { stone }\end{array}$ & Schist & Gneiss & $\begin{array}{l}\text { Miscel- } \\
\text { laneous }\end{array}$ \\
\hline $\mathrm{J}$ & 97 & $\begin{array}{c}(D-13-15) \\
22 a d b b\end{array}$ & 10 & 3 & 0 & 5 & 12 & 0 & 2 & 1 & 64 & 3 \\
\hline $\mathbf{J}$ & 98 & $22 \mathrm{caab}$ & 2 & 3 & 0 & 0 & 18 & 0 & 1 & 4 & 70 & 2 \\
\hline $\mathbf{J}$ & 99 & $26 \mathrm{bdc}$ & 10 & 1 & 0 & 2 & 9 & 0 & 3 & 4 & 70 & 1 \\
\hline$J$ & 100 & 26bdb & 7 & 0 & 0 & 2 & 5 & 0 & 0 & 12 & 74 & 0 \\
\hline $\mathrm{J}$ & 101 & $26 c c a b$ & 17 & 0 & 0 & 0 & 14 & 0 & 6 & 3 & 60 & 0 \\
\hline $\mathrm{J}$ & 102 & $23 \mathrm{cca}$ & 0 & 0 & 0 & 0 & 0 & 0 & 0 & 10 & 90 & 0 \\
\hline $\mathrm{J}$ & 103 & $27 \mathrm{dcbc}$ & 11 & 0 & 0 & 2 & 26 & 0 & 7 & $\overline{5}$ & 49 & 0 \\
\hline
\end{tabular}


cementation by calcium carbonate that has resulted in concretionlike nodules within the beds.

The imbrication of tabular-shaped pebbles of Catalina Gneiss and the orientation of the crossbedding in the type III Rillito beds indicate that they were deposited by streams flowing to the west, southwest, south, and southeast, in general away from the front of the Santa Catalina Mountains. In addition, the particle size in the conglomerate decreases from north to south or away from the front of the Catalinas.

\section{Stratigraphic Relations}

The gradual increase in the percentage of Catalina Gneiss pebbles from type I through type III Rillito beds has been generally interpreted as an index of the decreasing age of the units involved (Voelger, 1953, p. 81). This gradual increase in the percentage of gneiss pebbles reflects the uplift of the ranges and the gradual uncovering of their core of Catalina Gneiss by removal of its cover of volcanic rocks, limestone, quartzite, and granite (Smith, 1910, p. 87).

The base of the Rillito beds is not exposed or was not recognized as such in the area mapped. Although it is certain that the type I Rillito beds are older than type II and type III, it was not determined whether they underlie these latter two units in angular unconformity or grade up into them. The type II and type III Rillito beds interfinger with each other in the eastern half of fault block $\mathrm{C}$ and, 
therefore, are, at least in part, mutually equivalent. However, most of type II must be older than the bulk of type III.

In most places the type I, II, and III Rillito beds are in normal fault contact with one another. Along the front of the Santa Catalina and Tanque Verde Mountains, the type I Rillito beds are in low-angle fault contact with the Catalina Gneiss. The last movement along this fault was probably normal. The type I Rillito beds overlie schist in lowangle fault contact at Observation Point in the Saguaro National Monument. The Rillito beds are overlain-in angular unconformity by undeformed basin-fill deposits and all younger deposits.

\section{Origin}

Type I

The pebble types present in the type I Rillito beds and the imbrication of these pebbles indicate that these beds were deposited by westerly, southwesterly, and northwesterly flowing streams whose source areas were underlain directly by volcanic rocks, granite, quartzite, limestone, and to a very limited extent by the Catalina Gneiss. The gneiss pebbles could only have been derived from somewhere within the present limits of the exposures of the Catalina Gneiss (fig. 3). The presence of gneiss pebbles in the type I Rillito beds 
indicates that the uplift and erosion of the present ranges were already in progress during the deposition of these beds.

Mudstone and gypsum beds of the type I Rillito beds are today located immediately adjacent to the steep fronts of the Santa Catalina and Tanque Verde Mountains. They were originally deposited in standing bodies of water at some considerable distance from a region of high relief.

The facts, when considered together, indicate that, although the uplift of the present ranges was in progress during the deposition of the type I Rilltto beds, the centers of uplift and the positions of the highlands and basins of deposition were different from those of today.

Type II

The increase in the percentage of pebbles of Catalina Gneiss in the type II Rillito beds indicates that the Catalina Gneiss was much more extensively exposed in the source area than it was during type I time. This could only have resulted from continued removal of the cover of volcanic rock, quartzite, limestone, and granite and the gradual uncovering of the underlying Catalina Gneiss, probably as the result of continuing uplift of the ranges.

The absence of mudstone in the type II Rillito beds indicates the absence of standing bodies of water and perhaps a greater proximity to the highland source area. 
The interbedding of red conglomerate of type $I I$ Rillito beds with light-gray conglomerate of type III reflects differences in the percentages of the different rock types that cropped out in the drainage basins of adjacent streams. This interbedding must be the result of the coalescing of the alluvial fans from two adjacent drainages. The drainage basin of one was underlain by the Catalina Gneiss and other rock types, possibly including type I of the Rillito beds; the basin of the adjacent fan was already denuded of nearly all rocks except the Catalina Gneiss. The interfingering of red beds with gray beds also indicates that the color of the deposits reflects the color of the source rocks rather than reflecting climatic conditions.

Type III

The pebble composition, the imbrication of the pebbles, and the areal distribution of the coarse and fine deposits of the type III Rillito beds all indicate that they were deposited by streams originating in the Santa Catalina, Tanque Verde, and Rincon Mountains at a time when the outline of these ranges was similar to the present configuration. The type III Rillito beds were deposited as coarse alluvial fans along the fronts of the ranges. These fans merged basinward with gradually finer deposits toward the center of the present basin. Finegrained deposits and gypsum and anhydrite deposits in the center of the basin indicate deposition in a closed basin. 


\section{Age and Correlation}

Fossils have not been found in the Rillito beds; thus, it is necessary to base estimates of their age and correlation upon structural and stratigraphic resemblances to dated formations in other areas.

Rocks of middle Tertiary age, as typified by the Helmet Fanglomerate (Cooper, 1960, p. 77-89), the Pantano Formation (Brennan, 1962, p. 45-57), and the Mineta Formation (Chew, 1962, p. 35-43), consist of brick-red to red-brown fanglomerate, sandstone, and mudstone and are associated with andesitic flows. They were deposited in valleys whose boundaries extended beyond the limits of the present basins. Middle Tertiary rocks were involved in the last major compressional deformation, which produced thrusting and folding and resulted in the formation of the present basin-and-range topography (Lance, 1960, p. 157-158; Brennan, 1962, p. 57; Chew, 1962, p. 35; Heindl, 1962, p. 19; Cooley and Davidson, 1963, p. 22). They have been intruded by a distinctive porphyry that is characterized by abundant large tabular phenocrysts of plagioclase and known as the "Turkey Track Porphyry" (Heindl, 1959, p. 156; Cooper, 1960, p. 82-83; Brennan, 1962, p. 5054; Chew, 1962, p. 41). It has been suggested that this porphyry may serve as a marker for the regional correlation of the middle Tertiary formations (Cooper, 1961, p. 30). A fossil tooth from the Mineta Formation has been described by Lance (1960, p. 156) as "of approximately 
Lower Miocene age, certainly no older than Upper Oligocene or younger than Middle Miocene. " An ash flow from within the Pantano Formation yielded a potassium-argon age of $34.8 \mathrm{~m} . \mathrm{y}_{\bullet} \pm 2.1$, which places it at the Oligocene-Eocene boundary (Damon, 1962, p. 28).

Sediments of late Tertiary and Quaternary age were deposited in the modern basins (Lance, 1960, p..156), and their composition is reflective of the adjacent highlands (Cooley and Davidson, 1963, p. 27; Heindl, 1963, p. 14). Vertebrate fossils from fine-grained basin sediments near Redington in the San Pedro Valley are of middle Pliocene age. Vertebrate fossils from similar fine-grained basin sediments near Benson in the San Pedro Valley and from the Safford basin are of upper Pliocene and lower Pleistocene age (Lance, 1960, p. 156). Current workers have not reached agreement as to the structural and stratigraphic relations that exist between the fossil-bearing beds of middle Pliocene age and those of upper Pliocene and lower Pleistocene age. Lance $(1960$, p. 156) considers the fossil localities near Redington and Benson to be parts of one continuous sequence of fine-grained deposits, which extends to the margins of the basin and are not involved in major faulting.

Heindl (1963, p. 21) describes the middle Pliocene fossilbearing beds near Redington as being fine-grained equivalents of his Quiburis Formation, which he describes as being involved in block faulting. 
Cooley and Davidson (oral communication, 1966) believe that the beds bearing middle Pliocene fossils are involved in major normal faulting and that they are separated from the undeformed beds bearing late Pliocene or early Pleistocene fossils by an angular unconformity. A.middle Tertiary age for the type I Rillito beds seems to be indicated by their dark-red color and by evidence that they were deposited in a basin whose boundaries extended beyond the limits of the present basin. There is also some evidence that they were involved in folding. The presence of pebbles of Turkey Track Porphyry in the type I Rillito beds may indicate an age somewhat younger than the Pantano, Mineta, and Helmet Formations, all of which are intruded by the porphyry. A somewhat younger age may also be indicated by its content of Catalina Gneiss pebbles. Damon and others (1963, p. 118), on the basis of potassium-argon determinations of the age of the Catalina Gneiss, suggest that the uplift of the ranges had progressed to the point that metamorphism had terminated by late Oligocene-early Miocene time. The gneiss probably was not exposed to erosion until a considerable time after the metamorphism had ceased.

A late Tertiary age for the type III Rillito beds is indicated by the evidence that they were deposited in the modern basin by streams that were eroding highlands located in the approximate positions of the Santa Catalina, Tanque Verde, and Rincon Mountains. A middle Pliocene age or older may be indicated by the fact that they are involved in 
block faulting and are overlain in angular unconformity by the undeformed basin-fill deposits. They may be equivalent to the Quiburis Formation of Heindl (1963, p. 21) and the "deformed gravel" of Cooley and Davidson (1963, p. 21, 27), which they describe as coarse-grained gravel, tilted and moderately deformed by normal faulting, and exposed along the flanks of the ranges in the Safford basin and San Pedro Valley.

Some of the exposures of the type II Rillito beds are equivalent in age to the older units in the type III Rillito beds. Other exposures appear to be considerably older than the bulk of the type III units and must be intermediate in age between types $I$ and $\amalg$.

\section{Major Normal Faults}

The major normal faults (pl. 1; fig. 21) are exposed only in a places; in most places, they are concealed by younger deposits. The faults were mapped using indirect evidence, which consisted of changes in lithologies that take place across northwest- or northeast-trending lines. These changes are accompanied by changes in bedding attitude. The change in lithology across the faults is, in some places, indicated on aerial photos by color differences. The northeast-trending major faults are reflected by major northeast-trending straight washes, which lie along the traces. 
The major normal faults either trend northwest or northeast. The northwest-trending faults appear to be offset by the northeasttrending faults and, therefore, must be somewhat older.

The northwest-trending faults, with one exception, dip steeply southwest and are downthrown on their southwest sides. They drop the rocks of the piedmont area down with respect to the rocks of the ranges. The exception noted above, the northern border fault of block $D$, dips northeast and is downthrown on its northeast side. This fault is an antithetic fault with respect to the main displacement of the other major normal faults. It tends to reduce the overall structural displacement between the ranges and the piedmont rocks and results in the graben structure of block C.

The northwest-trending faults dip considerably steeper to the south than the Catalina fault and probably merge into the Catalina fault at depth. Movement along the major normal faults took place between the Rillito beds at shallow horizons and between the Rillito beds and the Catalina Gneiss at greater depths.

The northwest-trending boundary fault of block E appears to become tangential to the Catalina fault along the northwestern extension of its trace. This relation is probably representative of the general relation of the northwest-trending faults to the Catalina fault. As explained in a pervious section, the Catalina fault is interpreted as a preexisting thrust fault that has later normal movement. Movement along 
the major normal faults would result in recurrent movement along the Catalina fault. Blocks of the Rillito beds were rotated at different angles, but the structurally more competent gneiss was unaffected by this normal faulting.

The northeast-trending major normal faults dip steeply southeast or northwest and are downthrown on their southeast and northwest sides. They appear to cut and offset the northwest-trending faults, whose traces have been offset in the direction of their dip on the upthrown sides. These faults end at the Catalina fault without extending across it into the gneiss.

Minor Normal Faults

The outcrops of the Rillito beds are broken by minor normal faults with displacements that range from a few inches to a few feet (figs. 24B and 26A). The attitudes of many of these faults were recorded and are summarized here in the form of strike and dip diagrams (figs. 27, 28, and 29); each diagram represents strikes and dips within one of the fault blocks.

The number of faults represented by each diagram differs greatly and is dependent on the number of faults measured for each block. This in turn was proportional to the number of exposures of the Rillito beds in each fault block or inversely proportional to the amount of cover. Different scales are used in the diagrams to make them 


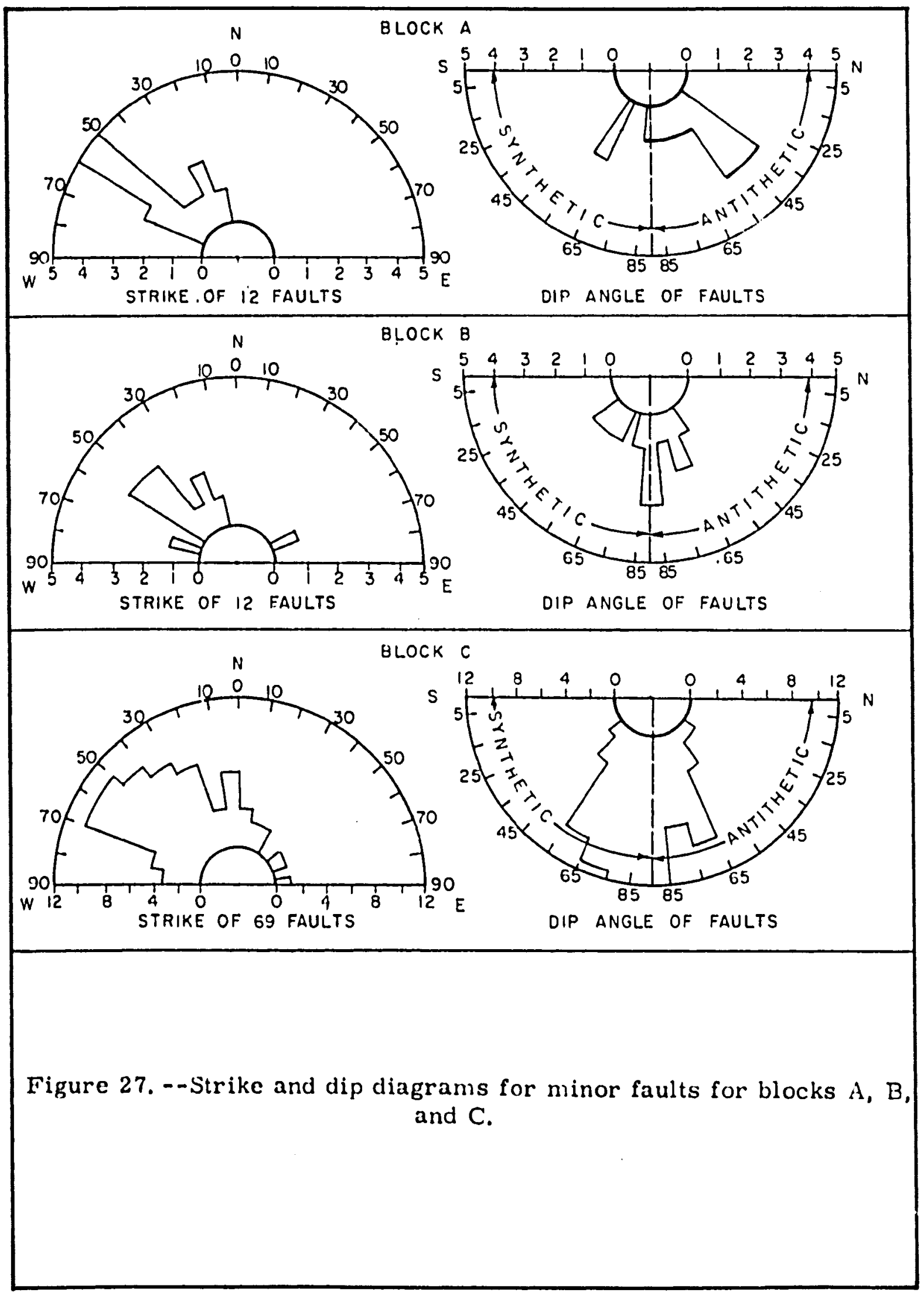




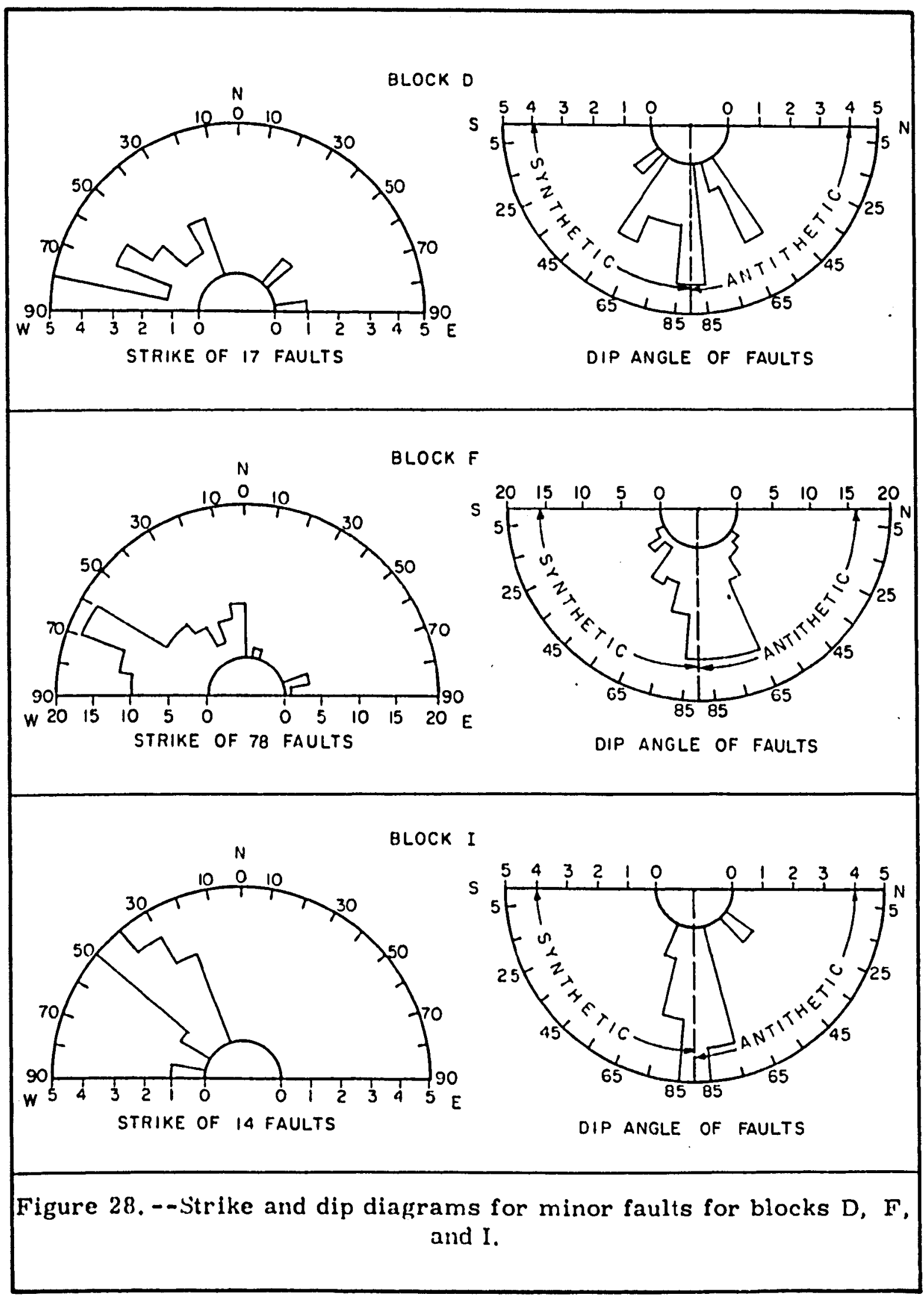




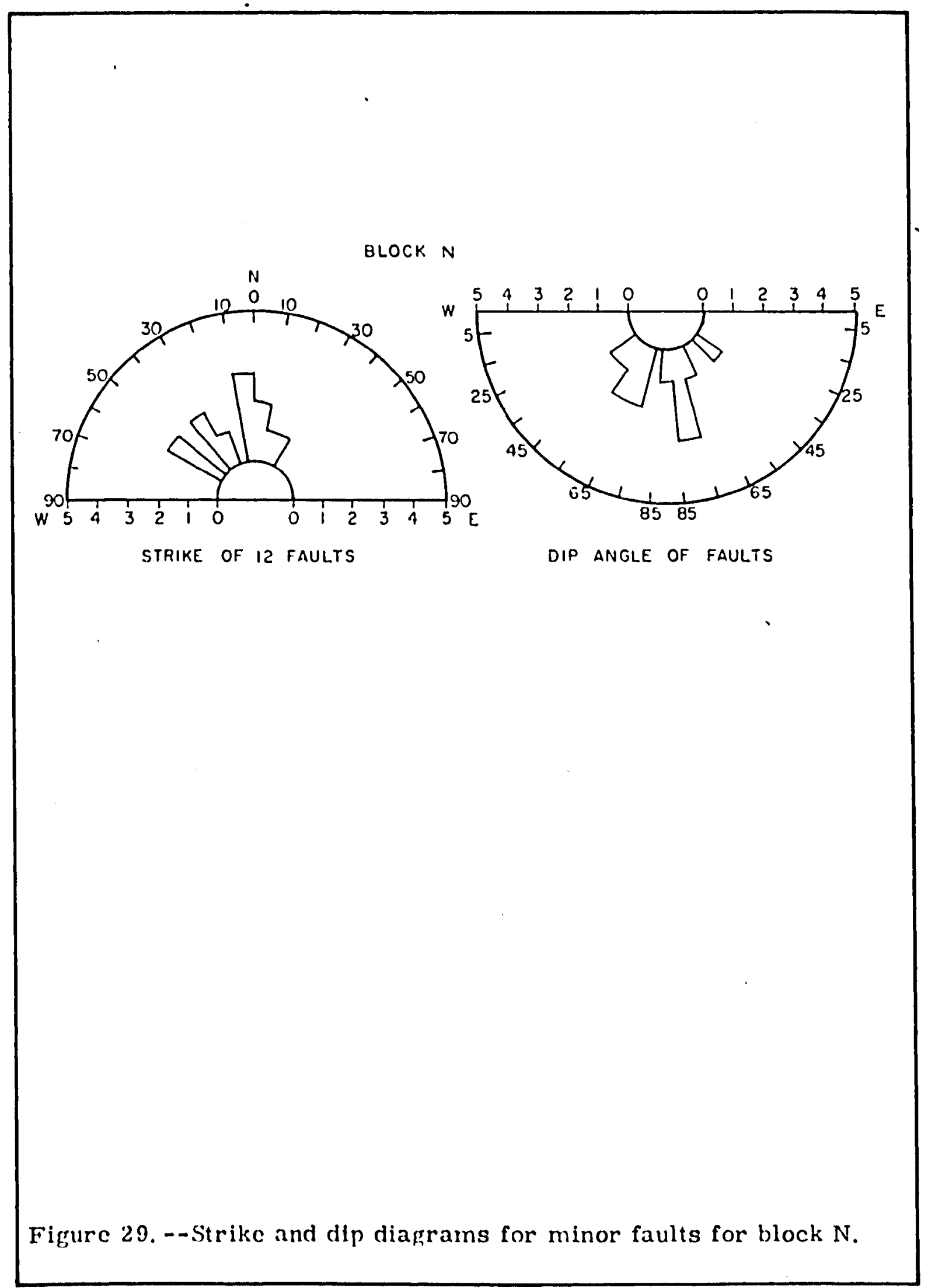


more readable; this must be kept in mind when interpreting their significance. No diagrams are included for blocks $E, G, H, J, K, L$, or $M$ due to an insufficient number of measurements from these blocks. The strike diagrams for the minor faults in blocks $A, B, C$, $D, F$, and I show a great dominance of northwest-trending minor normal faults over all other trends. This trend might tend to be emphasized because the washes and, therefore, the exposures of the Rillito beds along them are aligned in southwest-northeast directions. As a result, they transect mainly northwest-trending faults and parallel northeast-trending faults; thus, more northwest-trending faults would be seen and recorded. The dominant northeast-trending pattern of the drainage suggests the possibility of its control by northeast-trending faults. Opposed to this, however, the drainage pattern in block $E$ is southeast. In spite of this trend, which would transect and expose northeast-trending faults, five faults observed (not plotted) in block E had trends between N. $2^{\circ}-60^{\circ} \mathrm{W}$.

The 12 faults measured in block $\mathrm{N}$ have more of a north-south element in their trend than those in the other blocks. This block is geographically much removed from the others and borders the northwest front of the Tanque Verde Mountains rather than the southern front of the Santa Catalina Mountains.

The dip diagrams illustrate the relative steepness of the minor faults but also show the proportion of the faults that dip toward or away 
from the ranges and that are, therefore, antithetic and synthetic faults. As all the faults included are probably normal, they are all downthrown on the side to which they are dipping. Thus, faults shown dipping to the north are downthrown on the north and are antithetic faults; those dipping to the south are downthrown on the south and are synthetic faults. A glance at the dip diagrams gives an idea of the dip angle, the relative displacement, and the antithetic or synthetic nature of the faults.

\section{Bedding Attitudes}

One of the distinguishing properties of the Rillito beds, as seen in outcrops, is that they are nearly always dipping at an angle that is too steep to reasonably be considered original dip (figs. $23 \mathrm{~B}, 24,25$, 26A). The directions of dip are quite variable; in most places they dip away from the mountains but locally toward or oblique.

The attitude of the bedding planes in the different fault blocks has been generalized on figure 30. Changes in strike and dip in individual fault blocks and between blocks usually take place sharply and appear to represent tilting of the rigid blocks rather than folding.

Folds and Reverse Faults

Small folds were observed at several places in the Rillito beds. A small chevron fold with an amplitude of about 3 feet and an axis 


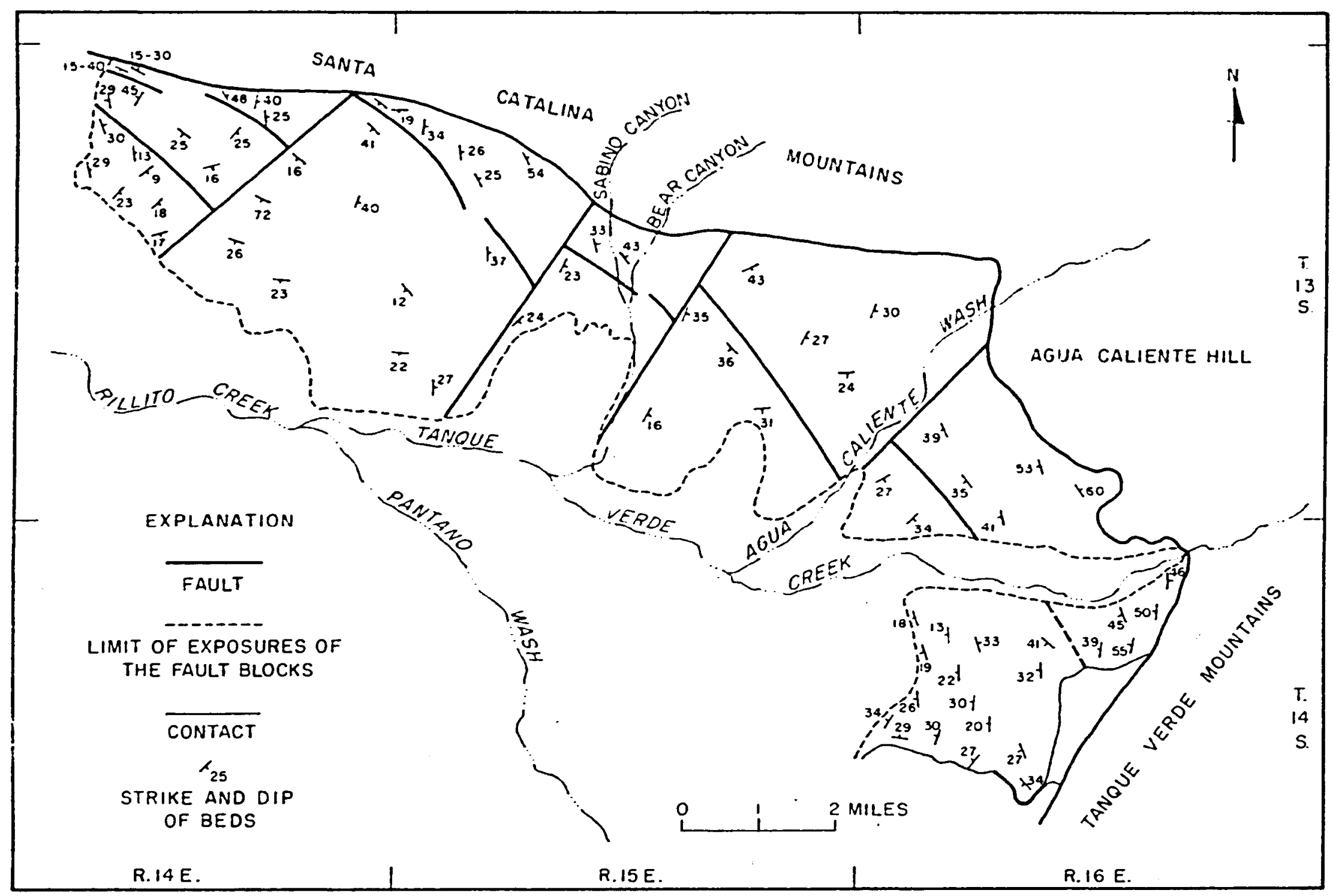

Figure 30.--Generalized bedding attitudes within the fault blocks. 
trending $\mathrm{N} .40^{\circ} \mathrm{W}$. was observed in the type I mudstone and sandstone of block $\mathrm{D}$. The type I mudstone of block $\mathrm{K}$ locally shows a diversity of dips and regionally shows dip reversals that may be the result of folding. A small drag fold was observed in block $\mathrm{K}$ and was associated with a very small reverse fault. The type I Rillito beds that cap Observation Point in block $\mathrm{N}$ show a number of small folds. They lie on a very gently dipping fault that separates them from the underlying schist. Several regional reversals of dip in block $\mathrm{N}$ may be the result of folding.

Two very small reverse faults were observed in the type I Rillito beds at one locality in the extreme western edge of block $\mathrm{E}$. Displacement was 2 inches. In block $K$ a small reverse fault that strikes N. $6^{\circ} \mathrm{W}$. and dips $88^{\circ}$ E. was observed in the type I Rillito beds.

\section{The Rillito Surface}

The name "Rillito surface" is proposed for the erosion surface in the Tucson basin that truncates the Rillito beds and all older rocks and is in turn overlain by the basin-fill deposits. The Rillito surface was carved after the period of normal faulting, which affected the type III Rillito beds and all older rocks, and before and during the deposition of the basin-fill deposits. At the time of their maximum extent, the basin-fill deposits probably concealed the entire Rillito surface, but a 
subsequent period of erosion has removed them from large areas and partially exhumed the surface along the margin of the basin.

In the central part of the Tucson basin and in part of the margin of the basin, the surface is the buried angular unconformity that separates the underlying deformed Rillito beds from the overlying undeformed basin-fill deposits. From the standpoint of ground water, it is important because it separates rocks of generally lower permeability below from sand and gravel of higher permeability above.

It is of interest geomorphically because when traced mountainward it corresponds to the exposed bedrock pediments that were carved across gneiss and granite along the fronts of the Santa Catalina and Tanque Verde Mountains (pl. 3).

Plate 4 shows subsurface contours of the Rillito surface. The configuration of the contours was defined by mapping exposures of the surface along the margin of the basin where it has been cut into or exhumed by post-basin-fill erosion (fig. $31 \mathrm{~A}$ ) and in other parts of the bar sin, where it is buried, by determining the altitude of the basin fillRillito beds contact in wells by means of well cuttings. The accuracy of the contours is limited by the number of exposures of the contact, the number and areal distribution of sampled wells that penetrate the basin-fill deposits, and the difficulty in many parts of the basin of distinguishing basin-fill deposits from type III Rillito beds in well cuttings. 
FIGURE 31

THE RILLITO SURFACE

\begin{abstract}
A.
Looking west at the elongate hill in sec. 19, T. 13 S., R. $15 \mathrm{E}$. The upper slopes of the hill are formed by coarse gravel of the basin-fill deposits. The lower dissected slopes are formed by tilted and faulted conglomerate and sandstone of the type III Rillito beds. The two formations are separated by an angular unconformity that slopes gently to the south and that is referred to in this report as the Rillito surface.
\end{abstract}

B. Looking northeast at the badly dissected exhumed granite pediment along the base of Samaniego Ridge on the northwest side of the Santa Catalina Mountains. The pediment corresponds to the Rillito surface. 

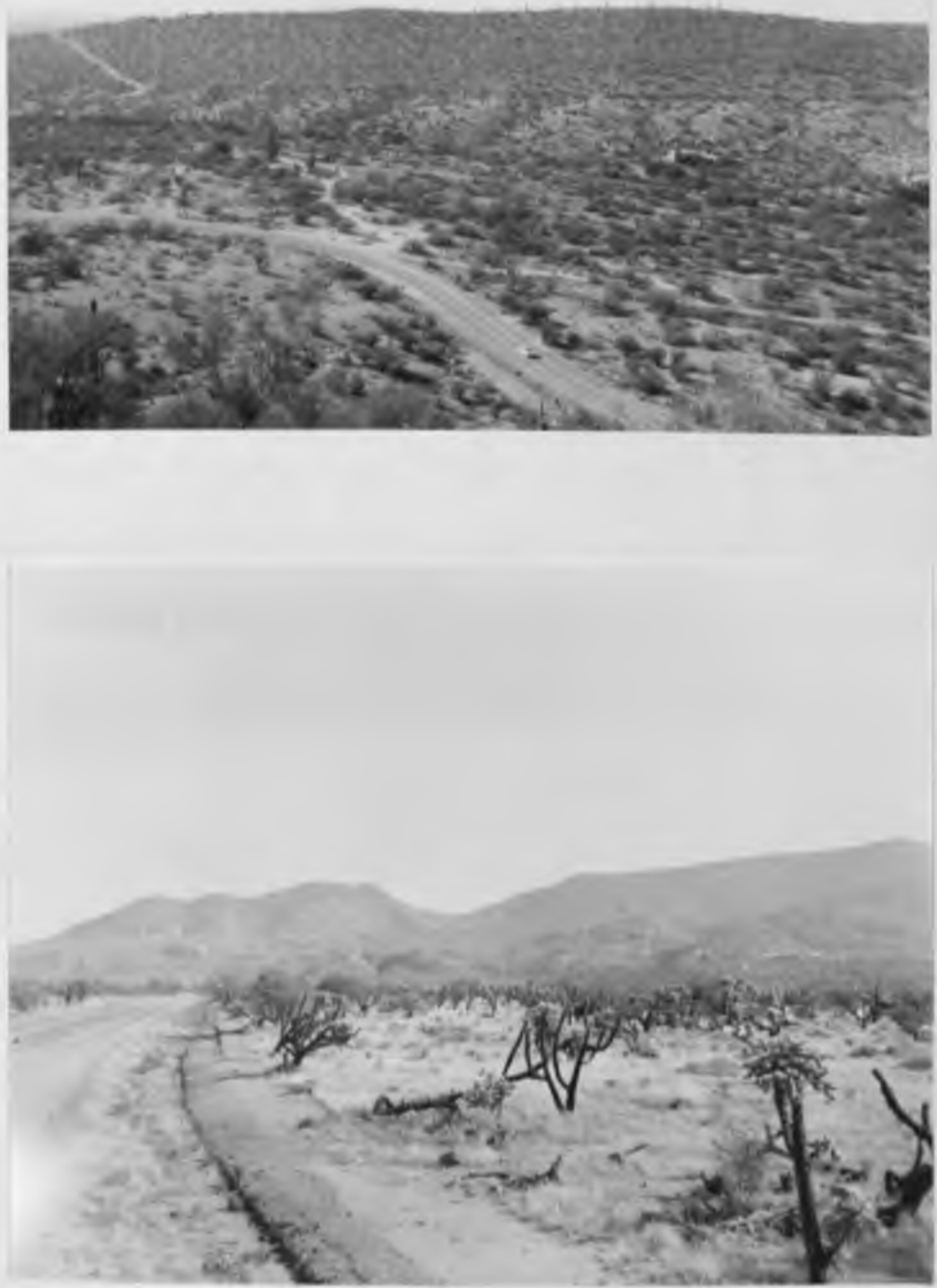
The position of these contours is determined with reasonable accuracy in the Catalina foothills. Here, there are many exposures of the surface, and the difference in the composition of the pebbles of the basin-fill deposits and the underlying older deposits makes it relatively easy to distinguish between the two formations.

The northwest trend and the even spacing of the contours ( $\mathrm{pl}$. 4) of the Rillito surface west of Ventana Canyon Wash and north of east Speedway indicate that in this area the surface slopes uniformly to the southwest away from the front of the Santa Catalina Mountains at a rate of about 235 feet per mile.

To the southwest along the edge of the Tucson Mountains it slopes to the east away from the front of the Tucson Mountains at a rate of about 165 feet per mile. The contour lines representing the Rillito surface in these two adjacent areas appear to join and close to the northwest and outline the northwest corner of an irregular-shaped closed basin.

The contours in the northeastern part of the basin show the approximate outlines of two troughs. The first trough trends north-south and is immediately east of Ventana Canyon Wash. Its location and alignment suggest that it was carved by concentrated runoff from Sabino and Bear Canyons. The second trough trends east-west and is slightly south of Tanque Verde Wash and east of Wilmont Road. Its 
position and alignment suggest that it was carved by runoff from the Tanque Verde Canyon drainage basin.

The contours are drawn with less certainty or omitted altogether in the eastern and central parts of the basin, partly due to the uncertainty in distinguishing between type III Rillito beds and the basin-fill deposits in well cuttings.

North of Rillito Creek the Rillito surface gradually rises to the north-northeast and successively truncates tilted and faulted Rillito beds, the Catalina fault, and a narrow band of the Catalina Gneiss north of the fault before terminating at the steep front of the range. Where it cuts across the gneiss, it is preserved as the narrow gneiss pediments and pediment benches (pl. 3) noted by earlier workers (Davis, 1931, p. 289-317; Tuan, 1959, p. 71). These bedrock pediments are present along most of the northwestern and southern edges of the Santa Catalina, Tanque Verde, and Rincon Mountains. They vary considerably in width and degree of exhumation and dissection. The bedrock pediments are the widest and have suffered a great amount of dissection along the western base of Samaniego Ridge (fig. 31B) on the northwest side of the Santa Catalina Mountains; their great width probably is due to the greater erodibility of the coarse-grained granite, which forms the range in this area (Tuan, 1959, p. 71). Post-basinfill erosion has swept the granite pediments clear of their former cover of basin-fill deposits and has cut deeply into the granite. 
To the south, along the western base of Pusch Ridge on the northwest side of the Santa Catalina Mountains, the range is formed by the very resistant Catalina Gneiss, and, as a result, the bedrock pediments are much narrower. In this area topographically prominent remnants of basin-fill alluvial fans lie on and occur above the extreme western edge of the gneiss pediments (fig. $32 ; \mathrm{pl}, 2$, section $\mathrm{C}^{-} \mathrm{C}^{\prime}$ ). The present position of these fan remnants on the gneiss pediments indicates that the pediments were formerly buried by the fans.

Along the south side of the Santa Catalina Mountains the condition of the gneiss pediments varies considerably as the result of varying amounts of post-basin-fill erosion. West of the center of sec. 4, T. 13 S., R. 14 E. erosion has been weak, and the basin-fill deposits still cover all but the very inner margin of the gneiss pediments. In the NE-1/4 sec. 4, erosion has been more intense, and it has completely exhumed the gneiss pediment but has left a high erosional remnant of the basin-fill deposits standing south of and above the southern margin of the pediment (fig. 19; pl. 2, section $B-B^{\prime}$ ). East of section 4, along the remainder of the southern front of the Santa Catalina Mountains, post-basin-fill erosion has been very intense; it has not only removed the basin-fill fans completely from the gneiss pediments and from a wide belt of the Rillito beds to the south but has cut into and removed a considerable thickness of the Rillito beds south of the Catalina fault. Because the gneiss pediments are considerably more resistant 


\section{FIGURE 32}

PEDIMENT AND ALLUVIAL FANS

View looking south along the southern half of the northwestern front of the Santa Catalina Mountains. The steep front of the range is visible to the left. The smooth surface in the center is a pediment carved across the Catalina Gneiss. Along the right edge of the picture are erosional remnants of the basinfill alluvial fans, which formerly concealed the pediments. 


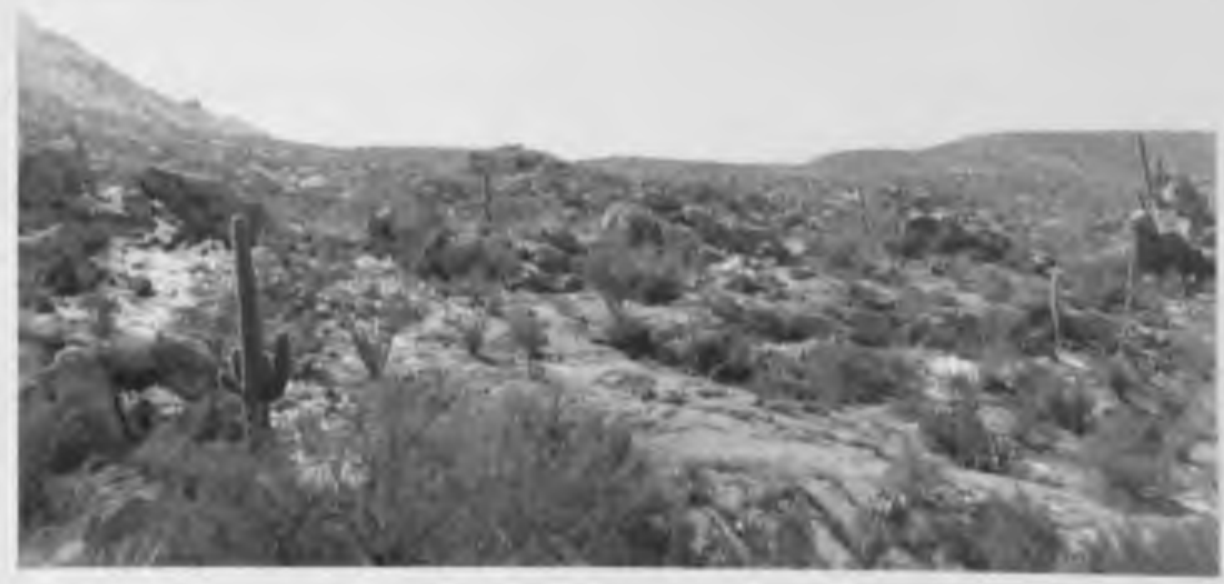


to erosion than the Rillito beds, they have been left standing as a badly dissected bench along the foot of the range. The bench is well preserved near the Pontatoc mine and extends about a mile east and a mile west of that locality (fig. $33 \mathrm{~A}, \mathrm{~B}$ ).

The Rillito surface did not extend as far north as the mountain front in sec. 1, T. 13 S., R. 14 E., as indicated by the fact that no gneiss pediment is present in that area.

The pediment bench is unusually wide but very strongly dis sected at the mouths of Sabino and Bear Canyons (fig. 34). Its greater width may be related to the greater concentration of runoff from the large drainage basins of Sabino and Bear Canyons (pl. 3). The pediment bench is present east of Bear Canyon but is poorly preserved. It is best preserved near the center of sec. 13, T. 13 S., R. 15 E. (fig. 34).

Gneiss pediments occur around the margins of Agua Caliente Hill and the northwest front of the Tanque Verde Mountains as far south as sec. 21 , T. $14 \mathrm{~S} .$, R. $16 \mathrm{E}$, , but the pediments appear to have had their surfaces lowered by post-basin-fill erosion so that they do not form a prominent bench.

A well-developed pediment bench is preserved along the northwest front of the Tanque Verde Mountains south of the center of sec. 28, T. 14 S., R. 16 E. This pediment is separated from its counterpart to the northeast by the ridge in the northern half of section 28 , which 
FIGURE 33

PEDIMENT BENCH

(Photos by Jay Dusard)

A.

Pediment bench carved across the Catalina Gneiss near Pontatoc mine. View looking east.

B.

Same locality as above; view looking northwest. 

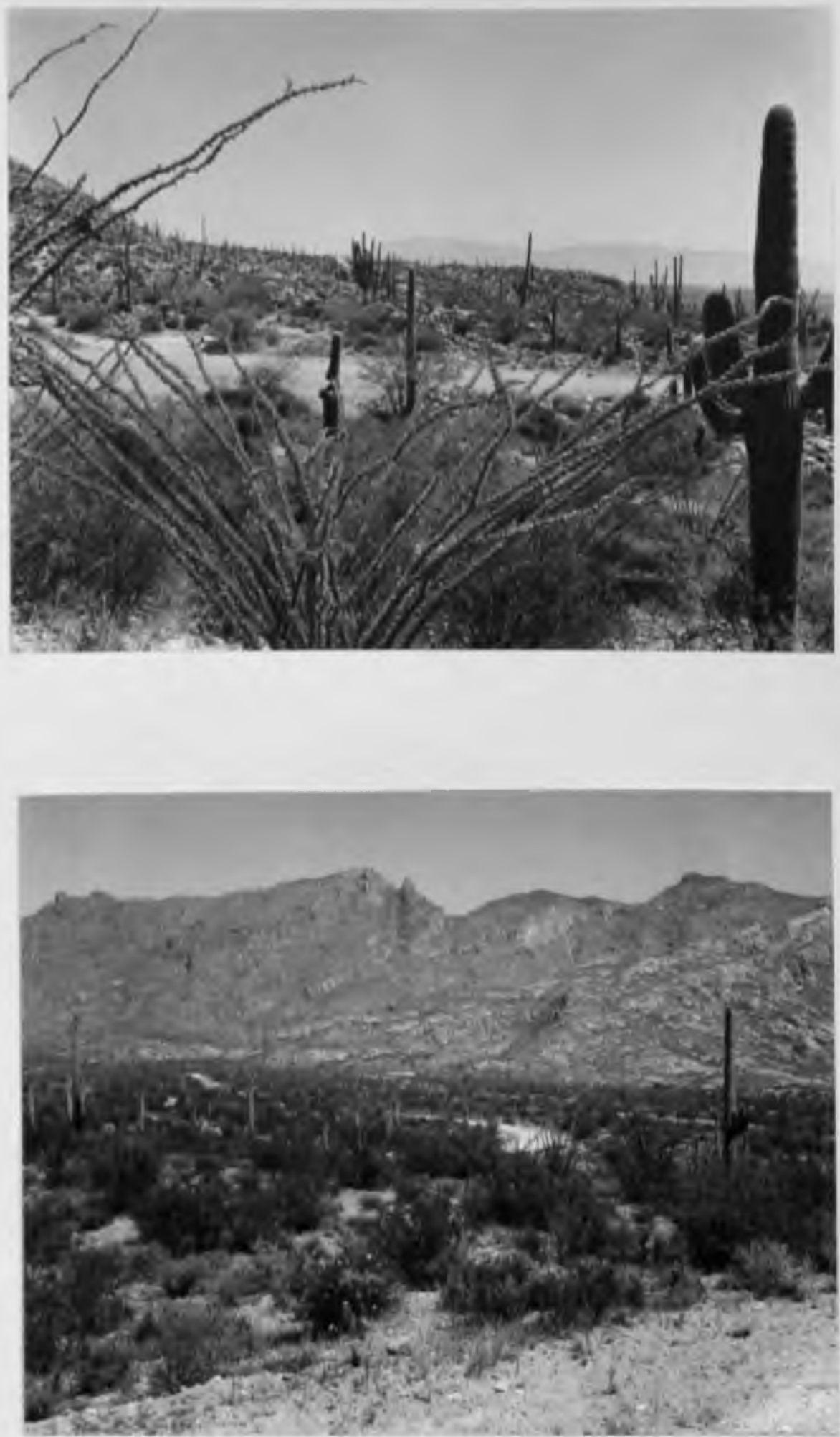
FIGURE 34

\title{
DISSECTED PEDIMENT BENCH
}

(Photo for fig. 34A by Tad Nichols; photo

for fig. 34B by Jay Dusard)

\begin{abstract}
A.
View of the front of the Santa Catalina Mountains between Bird Canyon and Agua Caliente Hill. Note the badly dissected pediment bench carved across the Catalina Gneiss along the foot of the ridge.
\end{abstract}

B.

Well-preserved pediment bench carved across the Catalina Gneiss in sec. 13, T. $13 \mathrm{~S} .$, R. $15 \mathrm{E}$. 

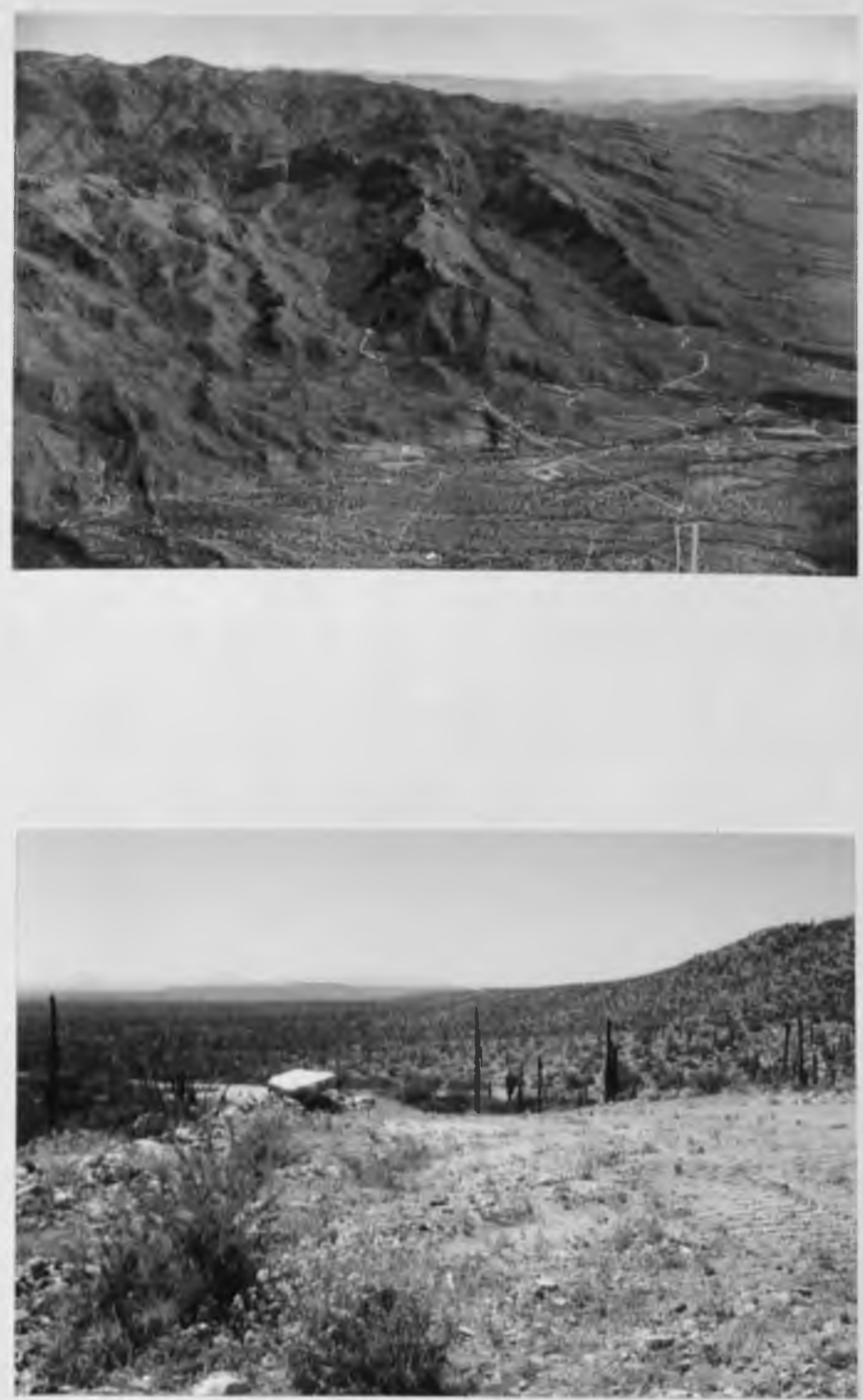
apparently acted as a divide between the northwest-flowing drainage, which carved the pediment to the northeast, and the west- to southwest-flowing drainage, which carved the pediment to the southwest. Basin-fill remnants lap up onto and conceal the outer margin of the pediment in sec. 32, T. 14 S., R. 16 E. and sec. 6, T. 15 S., R. 16 E.

A wide pediment truncates the Catalina Gneiss along the margins of Rincon Valley (p1. 3). It has been stripped of its cover of basin-fill deposits except along its extreme west extension along the south side of the Tanque Verde Mountains.

Locally, a few inselbergs or erosional remnants of older deposits rise above the level of the Rillito surface. The high hills of type III Rillito beds in secs, 1 and 12, T. 13 S., R. 14 E. stand above the Rillito surface and probably rose above the level of the alluvial fans that buried it. Likewise, the volcanic rocks of Twin Hills in sec. 19, T. 14 S., R. $16 \mathrm{E}$, the limestone hills along the northwest edge of the Tanque Verde Mountains, and several hard-rock hills in Rincon Valley all stood above the Rillito surface and probably stood as bedrock hills surrounded by a sea of alluvium in basin-fill time. 


\section{$\underline{\text { Basin-Fill Deposits }}$}

\section{Definition}

The name "basin-fill deposits" is used in this report for the body of silt, sand, and gravel in the Tucson basin that lies in angular unconformity above the Rillito beds and is in turn overlain disconformably by terrace deposits and Quaternary alluvium.

\section{Lithology}

The lithology of the basin-fill deposits is best exposed in the high erosional scarp that borders Rillito Creek on the north and the walls of washes and in roadcuts west of the extension of north Craycroft Road and north of Rillito Creek. These deposits are composed of a mixture of poorly sorted silt, sand, and gravel (fig. 35A). The main mass of the deposits is weakly cemented, but locally the basal 10 to 20 feet of the formation is very firmly cemented by calcium carbonate (fig. 35B).

The deposits, exclusive of their basal 10 to 60 feet, are composed dominantly of fragments of Catalina Gneiss, which were derived from erosion of the Santa Catalina, Tanque Verde, and Rincon Mountains. The basal part of the basin-fill deposits, where exposed, overlies the Rillito beds in angular unconformity and contains, in addition to gneiss, greater percentages of pebbles composed of volcanic rocks, 


\title{
FIGURE 35
}

BASIN-FILL DEPOSITS

\begin{abstract}
A.
Exposure of the basin-fill deposits in the SW-1/4SW-1/4NW1/4SW-1/4 sec. 18 , T. 13 S., R. $14 \mathrm{E}$. This exposure is about 240 feet above the base of the formation.
\end{abstract}

B.

Exposure of the cemented basal unit of the basin-fill deposits overlying impermeable mudstone of the Rillito beds in angular unconformity. The basin-fill deposits thin to the right or north and gradually thicken to the left or south. The exposure is in the NW-1/4SW-1/4NW-1/4 sec. 15, T. 13 S., R. $14 \mathrm{E}$. 

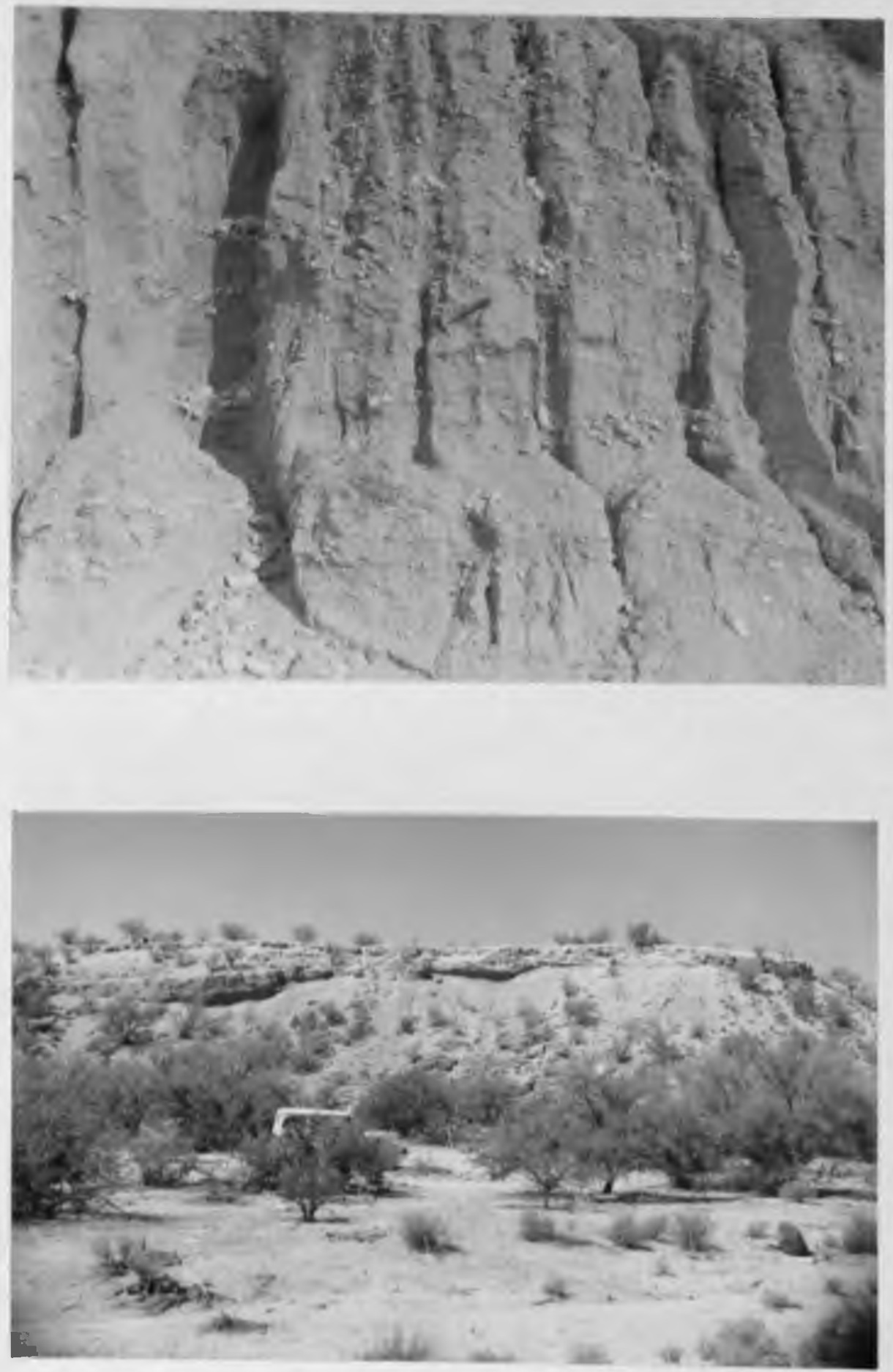
schist, pink granite, quartzite, and limestone than are present in the upper parts of the formation. These exotic pebbles are interpreted as having been derived from erosion of the underlying Rillito beds. Bedrock outcrops of granite, schist, volcanic rocks, limestone, and quartzite along the edges of the Rincon and Tanque Verde Mountains also supplied some material to the basin-fill deposits.

Table 9 gives 26 pebble counts that were made at exposures of the basin-fill deposits. Pebble counts 1-8, 10-12, and 21-24 were made in the lower 50 feet of the formation at exposures where the contact with the Rillito beds is well exposed. They are considered representative of the pebble types in the basal 50 feet of the basin-fill deposits. Pebble counts 9, 13-20, and 25-26 were made at outcrops representing higher stratigraphic horizons and are considered characteristic of the main body of basin-fill deposits.

The 15 pebble counts made in the basal 50 feet of these deposits contain an average of about 52 percent gneiss, as compared to 89 percent gneiss for the 11 pebble counts made in the main body of the formation. This increase in the number of gneiss pebbles and the decrease in exotic pebbles are probably somewhat gradual from bottom to top.

The basal 10 to 30 feet of the basin-fill deposits in secs. 15 and 16, T. 13 S., R. $14 \mathrm{E}$. is very strongly cemented with calcium carbonate (fig. 35B), which fills most of the spaces between the grains. As a result, the basal unit in this area forms a hard resistant ledge, 
which lies in angular unconformity upon the underlying impermeable red mudstone, sandstone, and conglomerate of the type I Rillito beds. Elsewhere, where it is exposed, the basal unit is only weakly to moderately cemented (fig. 36A). The strong cementation of the basal units in sections 15 and 16 may be the result of the highly impermeable red mudstone that underlies the unconformity, acting as a retardant to the downward movement of percolating ground water. This would concentrate groundwater flow in the basal unit of the basin-fill deposits and eventually could have resulted in strong cementation by calcium carbonate precipitated from the ground water. Elsewhere, where the underlying Rillito beds are more permeable, the flow of ground water was not concentrated above the contact, and as a result, the basal unit of the basin-fill deposits lacks the strong cementation (fig. 36A).

The color of the basin-fill deposits varies with the amount of material reworked from the underlying Rillito beds. The basal 30 to 60 feet of the formation, which contains large quantities of reworked material, generally varies in color from reddish brown (5YR $5 / 3$ to 5YR 5/4) to light reddish brown (5YR 6/3). The main body of the formation, which contains much less material from the Rillito beds, varies in color from pinkish gray (7.5YR 7/2) to light brown (7.5YR 6/4).

It seems unlikely that the basal part of the basin fill can be distinguished from the type III Rillito beds on the basis of pebble 
FIGURE 36

BASAL BASIN-FILL DEPOSITS

(Photo for fig. 36B by Jay Dusard)

A.

Exposure of the weakly cemented basal unit of the basin-fill deposits overlying sand and gravel units of the Rillito beds in angular unconformity. The exposure is in the NE-1/4SW-1/4NW$1 / 4$ sec. 17 , T. 13 S., R. 15 E.

B.

Exposure of basal basin-fill deposits in the NE-1/4NW-1/4SW$1 / 4$ sec. 4, T. 13 S., R. $14 \mathrm{E}$. Here, they lie in angular unconformity on sandstone and mudstone of the Rillito beds. 

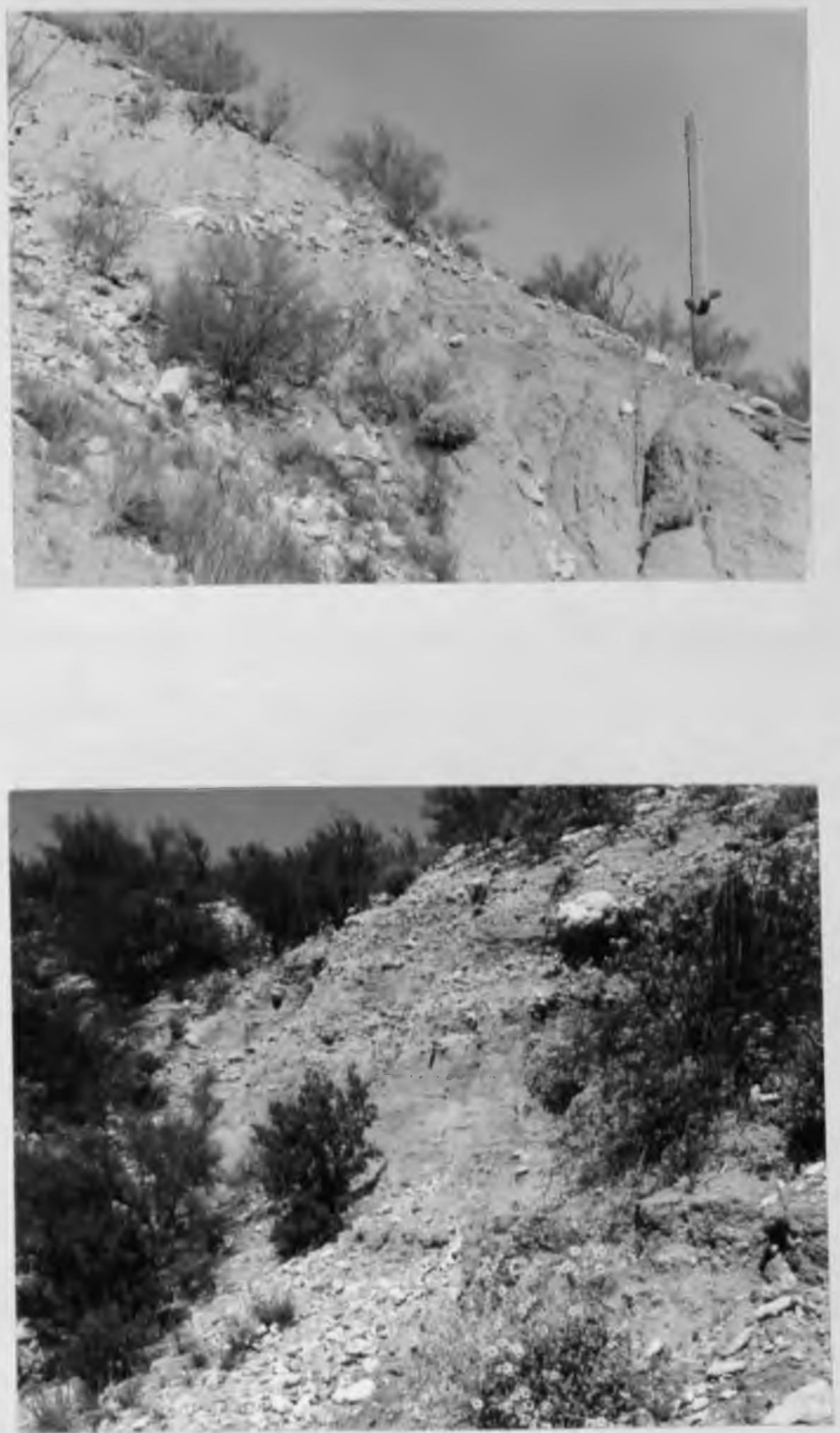
counts, color, and hardness alone. The cemented basal unit of the basin-fill deposits in secs. 15 and 16, T. 13 S., R. 14 E. closely resembles cemented ledges of the type III Rillito beds. It was distinguished in the field from the Rillito beds on the basis of its flatter dips, lack of joints and faults, and its position lying in angular unconformity on the Rillito beds.

The lithologic descriptions of four outcrops of the basin-fill deposits are included below as typical examples of their lithology. The first two descriptions are of the basal part of the formation, and the second two descriptions are considered typical of the main body of the formation.

Exposure 1 of basal basin fill

This exposure of basal basin fill is in the NE-1/4NW-1/4SW$1 / 4$ sec. 4, T. 13 S., R. 14 E. The exposure is in the face of a scarp separating two terrace surfaces. The exposure does not extend to the top of the scarp, which is capped by terrace gravel (fig. 36B).

Top of exposure:

Basal basin-fill unit:

Unit Description

No. Thickness in feet

3. Sandy gravel: forms vertical face; pebbles and boulders of gneiss predominant; boulders are as much as 3 feet long; pebbles of schist, volcanic rocks, and granite are present but less common 
Unit Description

No.

than in underlying units (see pebble count 2 , table 9); silt and sand fraction is light brown to reddish yellow (7.5YR 6/4-7.5YR 6/6); imbrication indicates streams flowed south and southwest; weakly cemented by calcium carbonate; poorly sorted; horizontally stratified but all as one bed; boulders are tabular; sample $1-65$ percent gravel, 27 percent sand, 8 percent fines; sample $2-63$ percent gravel, 27 percent sand, 10 percent fines.

2. Sandy gravel: forms gentle slope between units 1 and 3; pebbles as much as 8 inches long consist of gneiss, volcanic rocks, granite, schist, etc.; sand and silt fraction is reddish brown (5YR 5/4); imbrication shows streams flowed southwest and west; no cementation; better sorted and stratified than unit 3; unit is a single bed; pebbles are angular to subangular; sample 1-44 percent gravel, 46 percent sand, 10 percent fines; sample $2-32$ percent gravel, 57 percent sand, 11 percent fines.

1. Sand, gravel, and silt: forms vertical face; pebbles as much as 5 inches long consist of gneiss, schist, volcanic rocks, etc. (see pebble count 1 , table 9); silt and sand fraction is light reddish brown to reddish brown (5YR 6/3-5YR 5/3); imbrication shows streams flowed west and southwest; no cementation; poor sorting; no distinct beds; 60 percent gravel, 32 percent sand, 8 percent fines.

Angular unconformity:

Type I Rillito beds:

Hard red tilted sandstone and mudstone layers, pinkish gray and reddish brown (5YR 6/2-5YR 5/3). 
Exposure 2 of basal basin fill

This exposure of basal basin fill is in the NE-1/4SW-1/4NW1/4 sec. 17 , T. 13 S., R. 15 E. (fig. $36 \mathrm{~A}$ ). The exposure is a very prominent erosion scar in a hill directly adjacent to Ventana Canyon Wash. The top of the hill is capped by. 15 feet of coarse terrace gravel composed of gneiss boulders.

Top of scar:

Basal basin-fill unit:

Unit Description

No.

Thickness in feet

4. Sandy gravel: gneiss pebbles are predominant, but schist, volcanic rocks, granite, and quartzite are common (see pebble counts 22-24, table $9) ;$ silt and sand fraction is reddish brown to light reddish brown (5YR 5/3 -5YR 6/3); lenses of slabshaped gneiss boulders present; poor sorting; no distinct beds; sample $1-56$ percent gravel, 37 percent sand, 7 percent fines; sample $2-35$ percent gravel, 57 percent sand, 8 percent fines; sample $3-47$ percent gravel, 41 percent sand, 12 percent fines; sample $4-54$ percent gravel, 38 percent sand, 8 percent fines.

3. Boulders: gneiss boulders as much as $3-1 / 2$ feet long.

2. Sandy gravel: gneiss pebbles predominant, some as much as 6 inches long; pebbles of granite, volcanic rocks, quartzite, and sandstone are common (see pebble count 21, table 9); silt and sand fraction is reddish brown to light reddish brown (5YR 5/3$5 \mathrm{YR} \mathrm{6/3);} \mathrm{imbrication} \mathrm{indicates} \mathrm{streams} \mathrm{flowed}$ south; not cemented; stratified; poor sorting; sample $1-52$ percent gravel, 37 percent sand, 11 percent fines; sample 2-54 percent gravel, 36 percent sand,

60 
Unit Description

Thickness

No.

in feet

10 percent fines; sample $3-55$ percent gravel, 37 percent sand, 8 percent fines.

1. Boulder zone: pebbles and boulders are mainly 2 gneiss as much as 1 foot long in a sandy matrix; pebbles of volcanic rocks, granite, etc. are common but much less abundant than gneiss; light reddish brown (5YR 6/3).

Angular unconformity:

Type II Rillito beds:

Sandy silty gravel, well stratified but not sorted into beds; mostly pebble-size gravel and smaller; pebbles are volcanic rocks, granite, quartzite, and gneiss; loosely cemented; tilted (see pebble counts 59-60, table 7 in section on "Rillito beds").

Exposure 1 of basin fill

This exposure of basin fill is on the east side of north 1st Avenue about 150 yards north of River Road in the NW-1/4SW-1/4NW-1/4 SW-1/4 sec. 18 , T. 13 S., R. 14 E. (fig. $35 \mathrm{~A}$ ).

Top of roadcut:

Basin-fill unit:

Unit Description

Thickness

No. in feet

1. Sand and gravel: exposure is a vertical artificial cut; erosion has produced vertical ribs; pebbles as much as 10 inches long; gravel-size fraction increases in upper 15 feet of exposure; pebbles of fresh gneiss are most common rock type; minor 
Unit Description

No.

Thickness

in feet

quantities of pebbles of black schist and volcanic rocks (see pebble count 13, table 9); silt and sand fraction is light gray to pinkish gray (10YR 7/27.5YR 7/2); imbrication shows streams flowed south; weakly cemented by calcium carbonate; pebbles are in lenses; unit is stratified but not divisible into individual beds; flat bedded; subsurface information indicates the base of this exposure is about 240 feet above the base of the for mation; sample 1-19 percent gravel, 73 percent sand, 8 percent fines; sample 2-12 percent gravel, 56 percent sand, 32 percent fines; sample $3-23$ percent gravel, 74 percent sand, 3 percent fines.

Exposure 2 of basin fill

This series of exposures of the basin-fill deposits is on the southeast side of River Road starting about 400 feet northeast of the entrance to the Columbia gravel pit in the $N W-1 / 4 \mathrm{NW}-1 / 4 \mathrm{NE}-1 / 4$ sec. 27, T. $13 \mathrm{~S}$, , R. $14 \mathrm{E}$. The exposures occur as a series of roadcuts that reveal a total thickness of 42 feet over a distance of several hundred fect. The exposures occur in the side of a high erosional remnant of basin fill, which rises conspicuously above the level of the surrounding country. 
Top of roadcut:

Basin-fill unit:

Unit Description

No.

Thickness

in feet

42

1. Sand and gravel: pebbles as much as 8 inches long; pebbles are mostly gneiss with lesser amounts of quartzite, schist, volcanic rocks, etc. (see pebble count 20, table 9); silt and sand fraction is light brown to pinkish gray (7.5YR 6/4-7.5YR 7/2); imbrication indicates streams flowed south and southwest; weakly cemented by calcium carbonate, but locally stringers of caliche are present; poor sorting; stratified but not divisible into layers; pebbles occur as lenses and stringers; flat bedded; pebbles are tabular; sample $1-41$ percent gravel, 53 percent sand, 6 percent fines; sample $2-44$ percent gravel, 49 percent sand, 7 percent fines; sample $3-38$ percent gravel, 56 percent sand, 6 percent fines; sample $4-46$ percent gravel, 47 percent sand, 7 percent fines; sample 5-49 percent gravel, 43 percent sand, 8 percent fines; sample $6-59$ percent gravel, 36 percent sand, 5 percent fines; sample 7-49 percent gravel, 45 percent sand, 6 percent fines; base covered, probably underlain by 30 or 40 feet of basal basin fill.

Total basin-fill unit

\section{Origin}

The basin-fill deposits originated as coalescing alluvial fans whose apexes were at or within the mouths of canyons along the northwestern and southern fronts of the Santa Catalina, Tanque Verde, and Rincon Mountains. The origin is indicated by the composition and imbrication of the pebbles and by the areal distribution of coarse and fine facies within the basin-fill deposits. 
TABIL: 9

PEBBLA COUNTS OF BASIN-FILL EXPOSURES

\begin{tabular}{|c|c|c|c|c|c|c|c|c|}
\hline No. & Isocallion & $\begin{array}{l}\text { Voll- } \\
\text { cante } \\
\text { rocks } \\
\end{array}$ & $\begin{array}{c}\text { Gir:uln- } \\
\text { ile }\end{array}$ & $\begin{array}{l}\text { l.ime- } \\
\text { stone }\end{array}$ & $\begin{array}{c}\text { Quartz- } \\
\text { ite }\end{array}$ & Schist & Cinciss & $\begin{array}{c}\text { Mis- } \\
\text { cel- } \\
\text { lancous }\end{array}$ \\
\hline & $\mid(1)-13-1.1)$ & & & & & & & \\
\hline $1 \frac{11}{1}$ & 4cba & 21 & 4 & 0 & 12 & 33 & 30 & 0 \\
\hline $2 \frac{11}{11}$ & $4 c b n$ & 4 & () & 0 & 0 & 12 & 84 & 0 \\
\hline 311 & $15 b c d c$ & 6 & 2 & 4 & 5 & 23 & 52 & 8 \\
\hline 417 & $15 d$ dba & 10 & 0 & 0 & 6 & 41 & 43 & 0 \\
\hline 511 & $15 \mathrm{ddd}$ & 6 & 0 & 1 & 3 & 29 & 61 & 0 \\
\hline (i!) & 1 Gialbilat & 6 & 0 & i & 12 & 10 & 64 & 2 \\
\hline $7 \frac{11}{11}$ & 1 fiaced & 18 & 3 & 16 & 13 & 13 & 29 & 8 \\
\hline 811 & Ifibcal & 5 & 0 & 2 & 3 & 9 & 81 & 0 \\
\hline 9 & 16bdalc: & 0 & 0 & 0 & 0 & 4 & 96 & 0 \\
\hline 1018 & 1 fiace & 22 & 4 & 2 & 21 & 25 & 25 & 1 \\
\hline $11 \frac{1}{11}$ & 1 fdbab & 22 & 4 & 12 & 26 & 12 & 16 & 8 \\
\hline 1211 & 1 (idd)e:a & 38 & 4 & 2 & 23 & 8 & 22 & 3 \\
\hline 13 & $180 \mathrm{bcc}$ & 4 & 0 & 0 & 0 & 6 & 89 & 1 \\
\hline 14 & 22 bbba & 7 & 1 & 0 & 1 & 22 & 69 & 0 \\
\hline 15 & $22 \mathrm{bcbl}$ & 0 & 0 & 0 & 0 & 9 & 91 & 0 \\
\hline 16 & $261) \mathrm{cl}$ & 6 & 0 & 0 & 4 & 2 & 87 & 1 \\
\hline 17 & 2 fbeda & 4 & 1 & 11 & 1 & 3 & 91 & 0 \\
\hline 18 & 2(idail) & 1 & 1 & 0 & 3 & 10 & 85 & 0 \\
\hline 19 & 2 (idbab & 2 & 0 & 0 & 0 & 1 & 96 & 1 \\
\hline 20 & $27 a b b$ & 3 & 0 & 0 & 5 & 1 & 91 & 0 \\
\hline & $(D-13-15)$ & & & & & & & \\
\hline $21 \frac{1}{1}$ & $17 b(b b)$ & 22 & 4 & 0 & 9 & 6 & 57 & 2 \\
\hline $22 \frac{1}{1}$ & $17 b d b b$ & 17 & 0 & 0 & (i) & 4 & 73 & 0 \\
\hline 2311 & $17 \mathrm{bclbb}$ & 22 & 0 & 0 & 7 & 3 & 66 & 2 \\
\hline 2417 & $17 \mathrm{bdbl}$ & 10 & 1 & 1 & 7 & 7 & 74 & 0 \\
\hline 25 & $26 \mathrm{cdb}$ & 4 & ( ) & 0 & 2 & 5 & 89 & 0 \\
\hline 26 & $34 d d a a$ & 2 & 0 & () & 0 & 1 & 97 & 0 \\
\hline
\end{tabular}

I/ T3asial muit. 
The sand and gravel fraction of the basin-fill deposits is composed dominantly of fragments of the Catalina Gneiss-a rock that crops out only in the Santa Catalina, Tanque Verde, and Rincon Mountains. Therefore, the streams that deposited the basin-fill deposits had their drainage basins within these ranges. This conclusion is backed up by the orientation of the imbrication of the pebbles in the basin-fill deposits, which indicates deposition by streams flowing from these ranges toward the center of the basin.

The basin-fill deposits are very coarse grained near the fronts of the ranges; often they are composed of large boulders (fig. 37) and are very fine grained near the center of the basin where they grade into fine sand, silt, and clay-size fragments. This grain-size distribution is what would be expected if the basin-fill deposits were laid down as alluvial fans. Deposition of the alluvial fans took place at the mouths of canyons as the result of streams that emerged from the narrow confined canyons and spread out to many times their channel widths on the piedmont plain.

Areal Extent-Present and Past

In a brief discussion of the geomorphology of the Tucson area, Moore and others (1941, p. 17) made the following generalization: "A notable difference from some desert areas, however, is the absence of alluvial fans where streams emerge from the mountains." This 
FIGURE 37

COARSE BOULDER FACIES OF THE BASINFILL DEPOSITS

(Photo by Jay Dusard)

Boulder facies of the basin-fill alluvial-fan deposits. The exposure is about 1-1/2 miles south of the mouth of Sabino Canyon. 


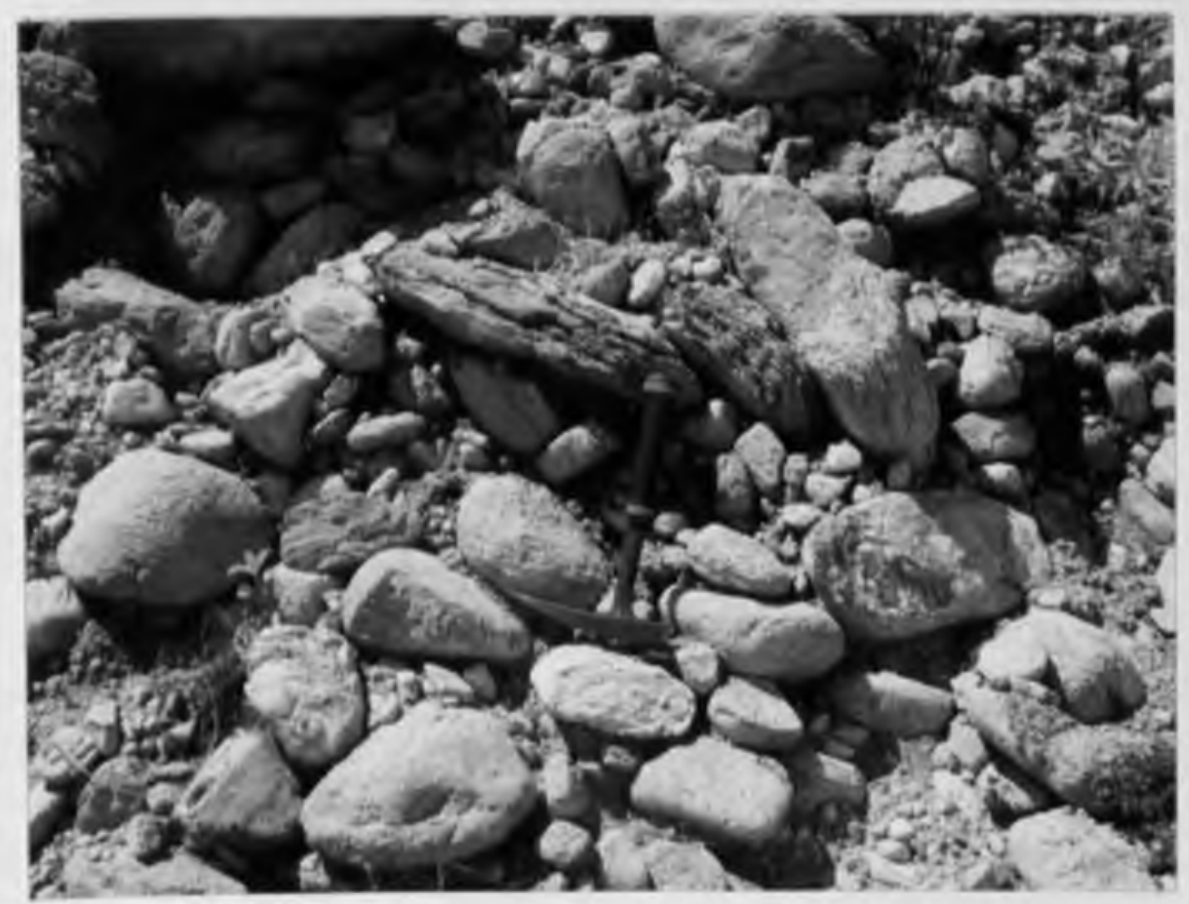


observation is supported by geologic mapping, which shows that along much of the range fronts the piedmont slope, especially opposite the mouths of major canyons, is an erosion surface carved across tilted and faulted Rillito beds. In most places the erosion surface is veneered by 5 to 60 feet of terrace deposits.

The absence of large alluvial fans along most of the mountain front is the result of intense erosion, which has cut into and through the fans and removed them completely from large areas along the margins of the Tucson basin.

The present areal extent of the basin-fill deposits is shown on plate 1 and is generalized on plate 3. These deposits, commonly concealed by terrace deposits, underlie the central part of the Tucson basin; however, only locally, where post-basin-fill erosion has been less intense, do they extend as far mountainward as the steep topographic fronts of the ranges. The latter occurs along the northwest front of the Santa Catalina Mountains in the area south of Alamo Canyon and along the southern front west of north Campbell Avenue. The same situation exists along the northwestern and southern edges of the extreme southwest tip of the Tanque Verde Mountains for a distance of about 5 miles. In these areas the basin-fill deposits form the piedmont slopes and lap up onto and conceal the outer margins of pediments carved across the gneissic bedrock of the ranges. Post-basin-fill erosion has dissected the basin-fill deposits in these areas and partially exhumed the inner 
edges of the bedrock pediments carved across the gneiss; however, it has not cut deep enough to expose the Rillito beds that underlie the basin-fill deposits in the piedmont area.

Along the remaining stretches of the mountain fronts, erosion has removed the basin-fill deposits from a belt of the adjacent piedmont slopes as much as 4 miles wide and has exposed the tilted and faulted Rillito beds upon which they were deposited (pls. 1 and 3). Isolated erosional remnants of the basin-fill deposits occur as hills in several places in this belt and lie in angular unconformity on the Rillito beds (p1. 2). These remnants indicate that the basin-fill deposits once buried this belt of Rillito beds and nearly everywhere extended to the steep fronts of the ranges. The intensity of the post-basin-fill erosion near the mouth of Sabino Canyon may be judged by the local relief of 400 feet between the top of the basin-fill remnant that forms the hills in sec. 21, T. 13 S., R. 15 E. and the floor of Ventana Canyon Wash directly to the west. This indicates a minimum of 400 feet of downcutting in this area since the close of basin-fill deposition.

Plate 3 shows the outlines and relative sizes of the drainage basins, which supply the many canyons that drain the ranges. It is at once obvious from this plate that Sabino, Bear, Agua Caliente, and Tanque Verde Canyons have much larger drainage basins than any of the other canyons in the ranges. It is logical to assume that these canyons supplied a greater quantity of debris and had larger and coarser 
alluvial fans at their mouths than the canyons with smaller drainage basins. This theory is supported by the basin-fill remnants in secs. 20 and 21, T. 13 S., R. 15 E., 1-1/2 miles from the mouths of Sabino and Bear Canyons (fig. 37). These deposits consist of coarse imbricated boulder gravel and are the coarsest deposits observed in the basin fill. They seem to be conclusive proof that major alluvial fans formerly extended from the mouths of Sabino and Bear Canyons.

The fans have been almost completely removed from the area adjacent to the mouths of the major canyons. The major drainage basins, which originally supplied the greatest amount of material for the construction of the fans, have apparently subsequently provided the greatest amount of runoff to cut into and remove these same fans.

The examination and interpretation of well cuttings collected during the drilling of wells in the Tucson basin (appendix A) indicate that the basin-fill deposits derived from erosion of the Santa Catalina, Tanque Verde, and Rincon Mountains extend as far west as the Santa Cruz River and at least as far south as the Benson Highway (U.S. Highway 80). This distribution of the basin-fill deposits indicates that Rillito Creek and Pantano Wash, which prevent the present mountain drainage from reaching the central part of the Tucson basin, did not exist during basin-fill time to obstruct the basinward extent of the fans but were established in their present positions by a subsequent period of erosion. 
This interpretation differs from the interpretation of Blissenbach (1951, p. 2, 7, 8), who considered the alluvial fans of the Catalinas to be only 4 miles in radial extent.

Age and Correlation

Fossils have not been found in the basin-fill deposits, and, therefore, estimates of their age and correlation must be based on structural and stratigraphic resemblances to dated formations in other areas. The basin-fill deposits are probably correlative with part of the Gila Conglomerate of the Safford basin. Knechtel (1938, p. 194-195, 200) describes the Gila Conglomerate as being generally undisturbed alluvial and lacustrine fill overlain unconformably by a capping of coarse terrace gravel. Davidson (1960, p. 123; 1961, p. 151-153) recognizes two units in the Gila Conglomerate of the Safford basin. The older unit is referred to as "deformed gravel" and is firmly cemented and moderately folded and faulted. It is overlain by a younger unit or "basin fill, "which is flat lying and unconsolidated and intertongues with fine-grained deposits. The fine-grained deposits contain fossils of upper Pliocene (Knechtel, 1938) or lower Pleistocene age (Lance, 1960, p. 157). The basin fill of the Tucson area probably is correlative with Davidson's "basin fill" of the Safford basin. 
Terraces and Terrace Deposits

Introduction

The evidence for several cycles of erosion subsequent to basin-fill deposition is preserved in the form of narrow river terraces and broad gently sloping erosion surfaces that bevel the basin-fill deposits and the Rillito beds. The narrow river terraces are present along Rillito Creek, Pantano Wash, and the Santa Cruz River and were carved by these streams. The broad erosion surfaces bevel most of the remainder of the basin or piedmont region and were carved by the integrated action of the many tributaries to and in grade with the major streams. Many writers refer to these broad erosion surfaces as pediments, but because of their close genetic relation to the river terraces and because locally they grade into the river terraces, this author will refer to them as broad terraces.

Locally, erosional remnants of basin-fill alluvial fans stand above the level of the highest terrace and give a measure of the amount of post-basin-fill crosion.

The terraces are usually covered by 5 to 30 feet of coarse gneissic gravel, but locally the deposits are as thick as 70 feet and have a very high silt and sand content. These deposits are referred to in this report as the terrace deposits. Locally, the terrace deposits 
have been removed by erosion, thus exposing the formations cut by the terraces.

\section{Previous Work}

Smith (1938, p. 50-78) described and mapped four topographic surfaces or levels in the Tucson area (fig. 38 ) that he named, in descending order, the University, Cemetery, and Jaynes terraces and the bottom land. According to his interpretation (fig. 39), the deposits directly underlying the University terrace represent an old original valley fill; whereas, the deposits underlying the Cemetery and Jaynes terraces and the bottom land represent a succession of river bottomland sediments, each lying in a trough excavated in the next older formation and formed during successive periods of erosion and deposition. Each successive trough was narrower and shallower, and each successive deposit was thinner than the one that preceded it.

Blissenbach (1951, p. 73-80) describes three levels or stages of alluvial fans in the Catalina foothills. Much of what he describes as alluvial fans is considered by the present author to represent relatively thin terrace deposits mantling the erosion surfaces or broad terraces of this report. 
R.13E

R. 14 E.

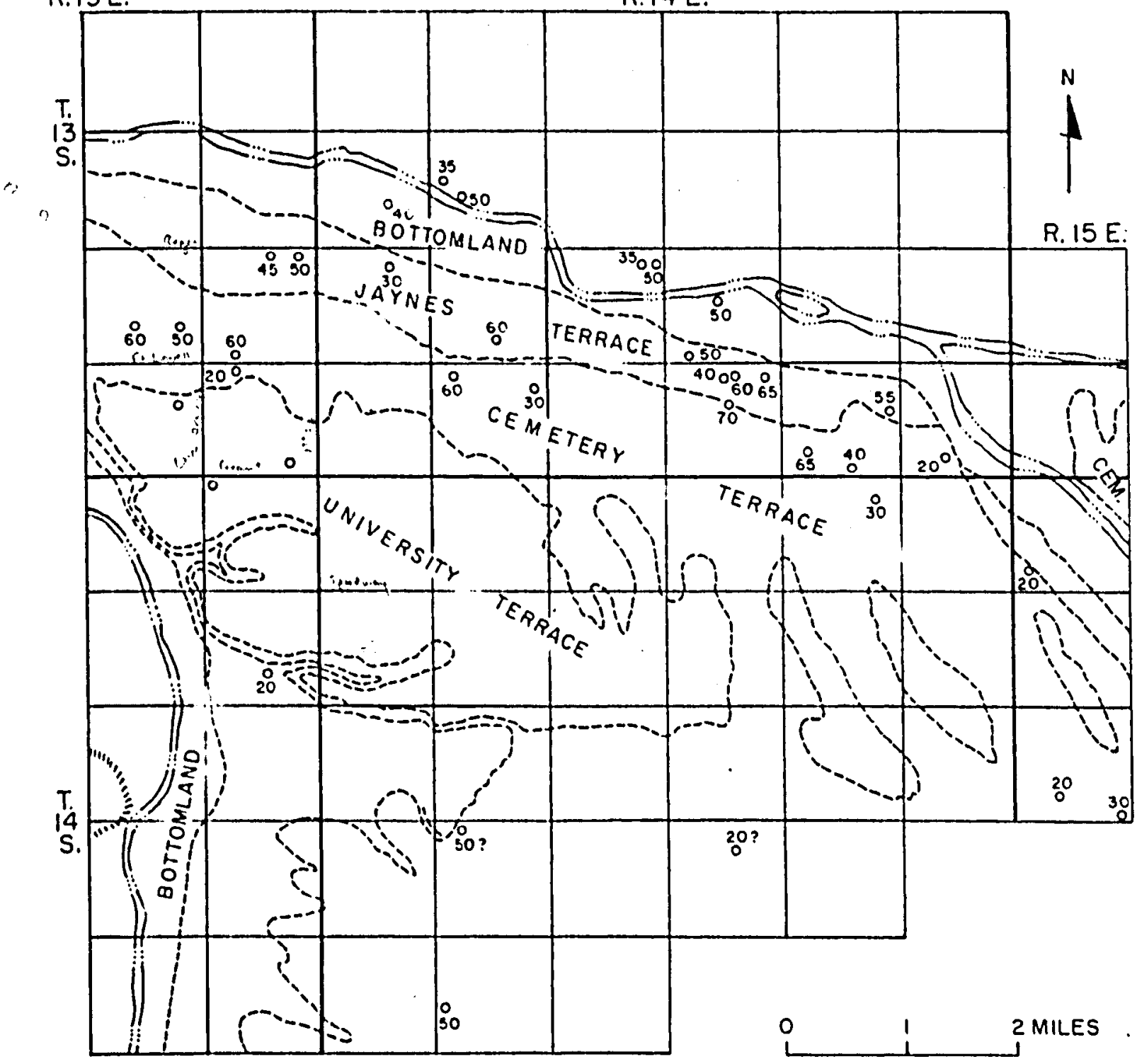

Figure 38. - Map showing the areal distribution of the University, Cemetery, and Jaynes terraces, bottom land, and the thicknesses of terrace deposits and Quaternary alluvium at well sites. (Revised from Smith, 1938, pl. V.) 


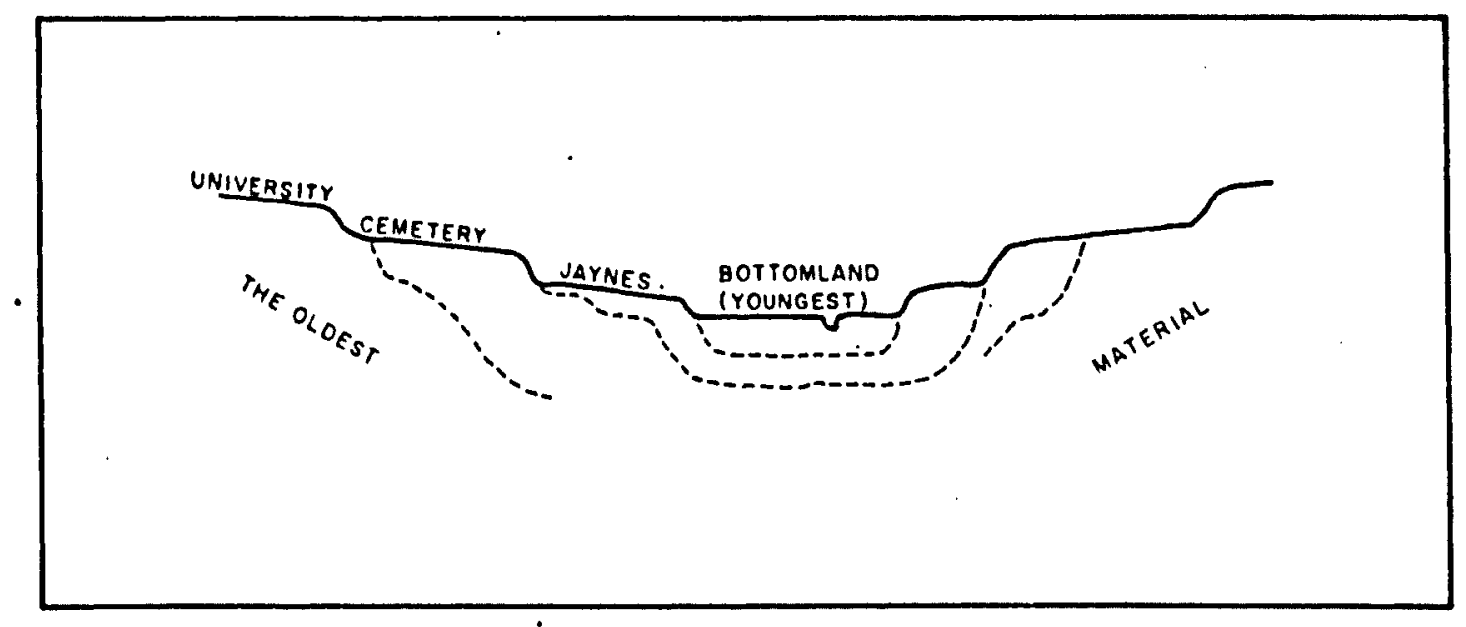

Figure 39. --Diagram showing Smith's interpretation of the terraces in the Tucson area. (After Smith, 1938, fig. 12.) 


\section{Reinterpretation of Smith's Terraces}

Geologic mapping and examination of formation cuttings from wells have yielded new facts useful for reinterpreting Smith's terraces. Examination of the cuttings from many wells drilled in the Tucson area reveals that terrace deposits and Quaternary alluvium may be distinguished from older deposits by differences in pebble composition and by staining on the pebbles. The terrace deposits and Quaternary alluvium contain pebbles of Catalina Gneiss, which are stained yellow; in the most common instances, where they overlie basin-fill deposits, the terrace deposits contain a higher percentage of nongneissic pebble types than is present in the underlying sediments. Using these criteria, the thickness of the terrace deposits and Quaternary alluvium found at 37 well sites was determined and plotted on figure 38 .

Wells on the University terrace did not encounter terrace deposits but were drilled directly into unstained basin-fill deposits. This seems to confirm Smith's interpretation of the University terrace as being underlain directly by an old original valley fill.

The remaining wells - on Cemetery and Jaynes terraces and the flood plain of Rillito Creek-penetrated thicknesses of terrace deposits and Quaternary alluvium that ranged from 20 to 70 feet.

Figure 40 is a north-south geologic cross section across Rillito Creek and along Campbell Avenue. It is based on information 


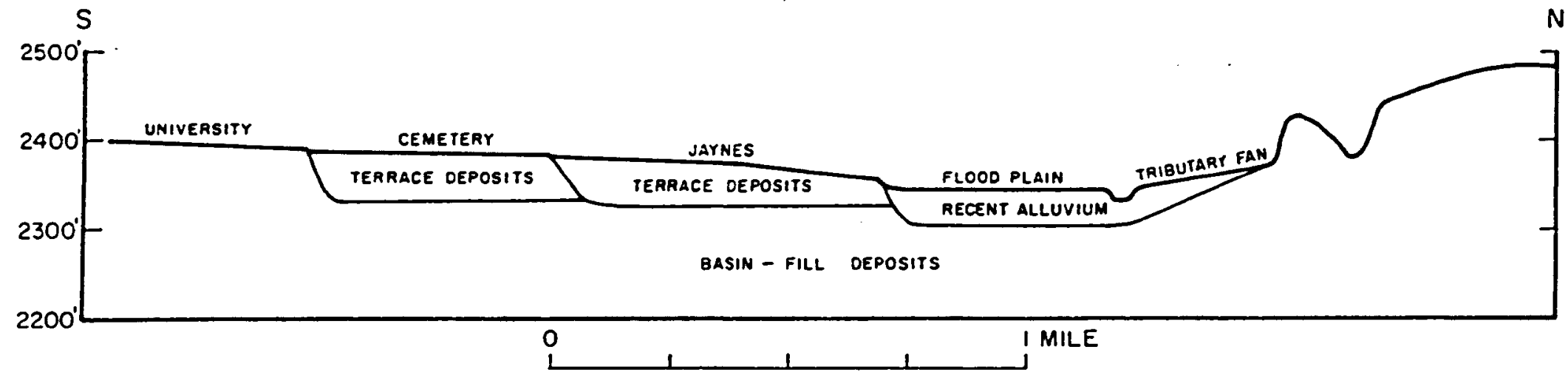

Figure 40.--Geologic cross section across Rillito Creek along Campbell Avenue showing the relation of physiography to the underlying deposits. 
from well cuttings and geologic mapping. It differs from Smith's general cross section (fig. 39) in two respects. First, it reveals that the narrow river terraces are developed only on the south side of Rillito Creek; whereas, the north bank is a steep erosional scarp carved in basin-fill deposits. Second, it shows that the thicknesses of the deposits underlying each terrace and the flood plain of Rillito Creek are all of the same order of magnitude.

\section{History of Rillito Creek}

Smith's terraces record the erosional and depositional history of Rillito Creek. They reveal that Rillito Creek has gone through three cycles of erosion and deposition, during which time it has migrated north and cut increasingly deeper into the underlying deposits. The position of the flood plain during each of the three cycles is marked by the Cemetery and Jaynes terraces and the present flood plain. Each downward migration to the north resulted in erosion of the north bank and the formation of a progressively higher erosional scarp along the north edge of the flood plain.

Rillito Creek was established about 1-1/4 miles south of its present position during an erosional cycle that marked the end of basinfill deposition. During the first cycle, Rillito Creek and its tributaries cut into the basin-fill deposits, carved the Cemetery terrace, and deposited the sediments that mantle it. The great areal extent of the 
Cemetery terrace suggests that it represents a longer period of time than is represented by the less extensive Jaynes terrace and the present flood plain.

The end of Cemetery deposition and the start of Jaynes erosion was marked by renewed downcutting and the northward migration of Rillito Creek. During Jaynes erosion and deposition, Rillito Creek occupied a new, lower, and more northerly flood plain, which is marked today by the position of the Jaynes terrace, and cut into its bank forming an erosional scarp.

This same cycle was repeated following the formation of the Jaynes terrace and resulted in the present flood plain of Rillito Creek and the erosional scarp along the north bank, which is now higher than at any time in its history.

Broad Terraces Along the Margins of the Basin

The areal distribution of terraces and erosional remnants of higher levels is shown on plate 5 . The stage of development and preservation of these terraces differ greatly throughout the area and make the correlation of individual terraces uncertain.

For the purposes of this report, the terraces and erosional remnants of higher levels are classified, in descending order, as levels I, II, and III and are tentatively correlated with the University, Cemetery, and Jaynes terraces. 
Level I

Level I is the highest and oldest level recognized and is represented by rounded hills and elongate ridges carved on basin-fill deposits. These hills and ridges are here interpreted as representing incompletely reduced remnants of the aggradational land surface as it existed at the end of basin-fill time. The local relief between the tops of these hills and the floors of adjacent washes gives a measure of the minimum amount of downcutting that has taken place in any particular area since basin-fill time. Locally, downcutting is more than 400 feet but usually is much less. Level I is tentatively correlated with the University terrace.

Level II

Level II is best developed and preserved in the southern half of the Catalina foothills west of Campbell Avenue. Here, it forms a gently sloping, mildly dissected, gravel-capped surface that bevels the underlying basin-fill deposits. The surface is also present in the lower foothills east of Campbell Avenue as far east as the extension of Craycroft Road, but it has suffered greater dissection.

Level II ends abruptly to the south in the high erosional scarp on the north side of Rillito Creek in the area west of Craycroft Road. This terrace was carved by washes tributary to Rillito Creek at a time 
when the creek occupied a position on the Cemetery terrace about $1-1 / 4$ miles south of the creek's present position. The terrace has been almost completely destroyed by subsequent erosion in the region between the extension of Craycroft Road and Sabino Creek, but locally it is preserved near the mouth of Ventana Canyon in the form of hills formed of type II Rillito beds that are locally capped by terrace gravel.

West of Sabino Creek the surface is preserved in the form of flat-topped mesas carved across type I Rillito beds and capped by as much as 20 feet of coarse gneissic terrace gravel.

Along the northwest side of the Tanque Verde Mountains the terrace is well developed but has suffered less dissection than it has in the area immediately north (described in the preceding paragraph). Here, it cuts type I and type II Rillito beds and is capped by 5 to 15 feet of terrace deposits (fig. 41A).

Level II also may be represented by the gently sloping topography between the Pantano and Tanque Verde Washes immediately east of their junction. Cuttings from several wells in this area indicate that it is underlain directly by terrace deposits. The gently sloping topography merges imperceptibly to the east with rolling dissected topography, which may represent remnants of level $\mathrm{I}$.

The terrace is well preserved south of the Tanque Verde Mountains and east of Pantano Wash, where it truncates basin-fill and older rocks and is capped by as much as 30 feet of terrace deposits. 


\title{
FIGURE 41
}

\section{TERRACE DEPOSITS}

\begin{abstract}
A.
Terrace deposits on an erosion surface or terrace carved across type I Rillito beds. Exposure is in the SW-1/4NW-1/4NW-1/4 sec. 10, T. 14 S., R. $16 \mathrm{E}$.
\end{abstract}

B.

Terrace gravel capping the type III Rillito beds along the west side of the Santa Catalina Mountains. 

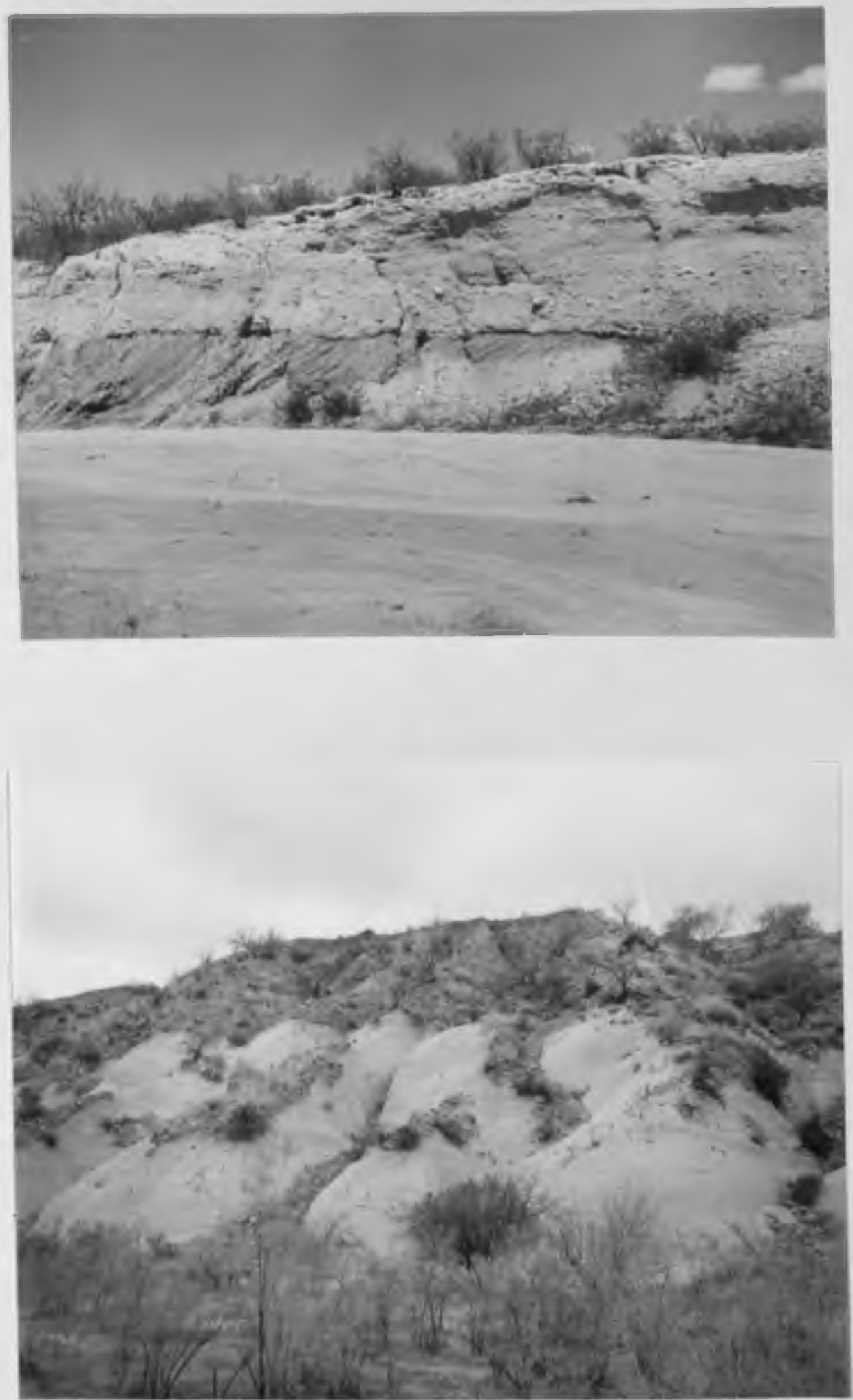
Reconnaissance mapping along the west side of the Santa Catalina Mountains reveals the presence of a well-developed gravelcapped terrace (pl. 5)-here tentatively correlated with level II (fig. 41B).

Level III

Level III is the lowest terrace recognized along the margin of the basin and occupies a position just above the flood plains of the modern washes. It is developed only in the area east of Campbell Avenue. The degree of dissection of this terrace and its height above the flood plains of the modern washes decrease from west to east. Between Campbell Avenue and Ventana Canyon.Wash, washes have cut through its mantle of terrace deposits, locally removed them almost completely, and exposed the underlying Rillito beds. Along the extreme southern part of the Catalina foothills, between Craycroft Road and Ventana Canyon Wash, the terrace has been stripped almost completely of its deposits and occupies the approximate position of the exhumed Rillito surface (basin fill-Rillito beds contact). It ends to the south in a low erosional scarp that overlooks the flood plain of Tanque Verde Wash. This scarp is noticeably lower than the scarp immediately to the west, which separates level II from the flood plain of Rillito Creek. Farther north adjacent to the front of the Catalinas, the terrace deposits are as much as 60 feet thick. 
East of Ventana Canyon Wash the terrace has suffered much less dissection, and only locally have washes cut deep enough into the terrace deposits to expose the underlying Rillito beds. Sabino Creek has cut into this terrace, and its flood plain is separated from the terrace by an erosional scarp; however, the terrace grades imperceptibly into the flood plains of Agua Caliente and Tanque Verde Washes without an intervening break in slope. The terrace deposits east of Ventana Canyon Wash locally are as much as 50 feet thick.

Terraces Along Pantano Wash and South of Tucson

Reconnaissance mapping along Pantano Wash reveals that as many as three-and in some places more-narrow gravel-capped river terraces are present along the wash. All the terraces appear to be below the level of the Cemetery terrace and are, therefore, probably equivalent to or younger than the Jaynes terrace or level III.

Along most of the length of Pantano Wash the narrow terraces are present along the west bank and absent along the east bank, which is an erosional scarp. This indicates that Pantano Wash has been cutting down and shifting eastward.

In the 4-mile-long stretch below Vail, the river terraces are developed on both sides of the wash, which indicates that the position of the wash in this stretch has remained stable. The desert west of Pantano Wash and south of Tucson is an area of low relief. Careful 
inspection, however, reveals the presence of elongate northwest-trending hills or rises separated by northwest-trending drainage flats. The rises appear to be the only indication of the University terrace and the flats the only indication of the Jaynes terrace. No attempt was made to map them.

\section{Quaternary Alluvium}

\section{Definition and Lithology}

The name "Quaternary alluvium" is used for the stream deposits that directly underlie the flood plains of Rillito, Tanque Verde, and Pantano Washes and their tributaries. They are composed of unconsolidated and uncemented silt, sand, and gravel deposited or transported by the streams and include material deposited as small alluvial fans on the flood plains of the larger washes at the mouths of their tributaries.

Along the narrow minor washes the deposits are thin and are composed mainly of sand and gravel. Along Rillito, Tanque Verde, and Pantano Washes they are much thicker and are composed of beds and lenses of silt and fine sand, representing flood-plain deposits, interfingering with lenses of sand and gravel, representing channel deposits. Examination of well cuttings reveals that gneiss is the dominant rock type present in the pebbles in the Quaternary alluvium; but 
pebbles of volcanic rocks, quartzite, granite, and limestone usually are present in lesser amounts. The gneiss pebbles are in most places coated with a yellow stain-a property that aids in distinguishing Quaternary alluvium from older formations.

\section{Thickness}

The thickness of the Quaternary alluvium was determined at 16 sites on the flood plains of Rillito, Tanque Verde, and Pantano Washes by inspection of cuttings collected during the drilling of water wells. It was also determined in 13 holes drilled in a line across the flood plain of Tanque Verde Creek using a truck-mounted power auger. Cuttings from seven wells drilled on the flood plain of Rillito Creek revealed thicknesses that ranged from 35 to 65 feet. Cuttings from two wells on the flood plain of Pantano Wash revealed thicknesses of 30 and 85 feet. Of the seven wells on the flood plain of Tanque Verde Creek, five had thicknesses of Quaternary alluvium that ranged between 30 and 60 feet. The remaining two had thicknesses of 120 and 150 feet-thicknesses that seem excessive and, therefore, possibly are subject to reinterpretation.

Thicknesses of Quaternary alluvium of more than 50 feet are probably the result of small alluvial fans being deposited on the flood plains of major washes at the mouths of tributaries and adding to the thickness of the alluvium. 
The power auger was used to determine the thickness of Quaternary alluvium underlying the flood plain of Tanque Verde Wash along the eastern edge of sec. 5, T. 14 S., R. 16 E. At this site the Quaternary alluvium overlies red mudstone of the type I Rillito beds and is readily distinguishable from them on the basis of color, composition, and induration.

The results of this augering are summarized in the geologic cross section (fig. 42). The depth of the Quaternary alluvium-mudstone contact was determined by observing the depth at which the drilling speed suddenly changed from very fast to very slow. The auger penetrated the unconsolidated Quaternary alluvium by pushing it aside rather than by transporting material to the surface; for this reason samples could not be examined. The augering revealed thicknesses that ranged from 9 to 54 feet. 


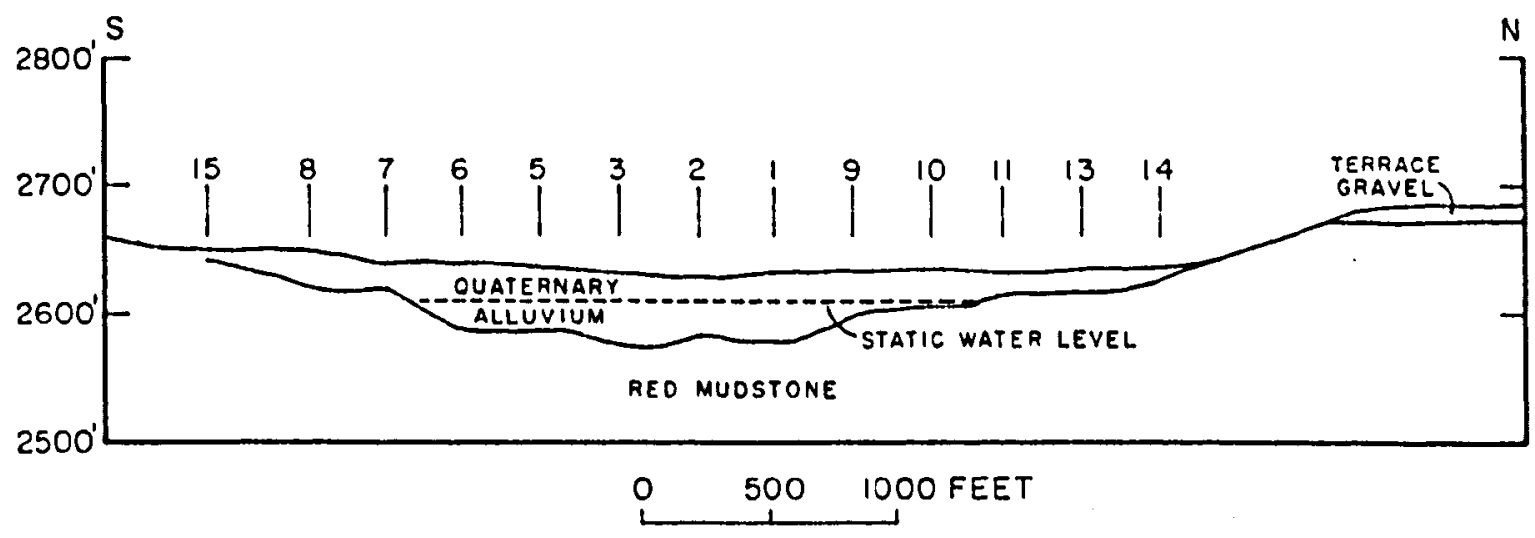

\begin{tabular}{c|c|c}
\hline $\begin{array}{c}\text { HOLE } \\
\text { NUMBER }\end{array}$ & $\begin{array}{c}\text { WATER LEVEL } \\
6 / 14 / 61\end{array}$ & $\begin{array}{c}\text { DEPTH TO REO } \\
\text { BEDS (FEET) }\end{array}$ \\
\hline 1 & 19.6 & 54 \\
2 & 19.3 & 40 \\
3 & & 52 \\
5 & & 47 \\
6 & 28.0 & 51 \\
7 & & 24 \\
8 & & 28 \\
9 & 17.5 & 29 \\
10 & 17.2 & 23 \\
11 & & 12 \\
13 & & 17 \\
14 & & 9 \\
15 & & 9
\end{tabular}

Figure 42. - Cross section along Wentworth Road between Speedway Boulevard and Tanque Verde Road. 


\section{SUBSURFACE GEOLOGY}

\section{Introduction}

Previous workers who have discussed the subsurface geology of the Tucson basin have had to base their interpretations on drillers' logs and a limited number of sample logs (Coulson, 1950; Kidwai, 1957; Schwalen and Shaw, 1957; Maddox, 1960; Streitz, 1962; Ganus, 1965). The present authors interpretation is based on sample logs and field mapping.

The following discussion deals with the analysis of cuttings collected during the drilling of water wells in the Tucson basin. An attempt is made to correlate the formations penetrated by the wells with formations mapped along the margins of the basin. The appendix includes the sample logs of 105 wells in the Tucson basin. Their locations are plotted on plate 4.

For purposes of discussion, the basin has.been divided into seven areas (pl. 4) based on the composition of the Rillito beds encountered in the wells in each area. In addition, a number of wells that fall outside these areas are included in the appendix as supplemental geologic data. 


\section{Rillito Creek Area}

Sample logs of 22 wells drilled in the Rillito Creek area (pl. 4) are included in appendix A. All but one of these wells are deep enough to penetrate the terrace deposits, Quaternary alluvium, and the basin-fill deposits and to bottom in the underlying Rillito beds.

Most of the wells are on the flood plain of Rillito Creek or on the Jaynes and Cemetery terraces. The uppermost samples from these wells are composed of stained gneiss pebbles and contain a higher percentage of exotic pebble types - rock types other than the Catalina Gneiss - than is present in the underlying basin-fill deposits. The stained samples are interpreted as representing terrace deposits and Quaternary alluvium and indicate thicknesses ranging from 20 to 70 feet.

The main body of the basin-fill deposits in these wells is characterized by the predominance of pebbles composed of clean white Catalina Gneiss. The contact between the basin-fill deposits and the underlying Rillito beds, in most instances, was selected at the depth at which the percentage of exotic pebbles markedly increases. This method may result in as much as 10 to 50 feet of the basal part of the basinfill deposits being included with the Rillito beds. Pebble counts made at outcrops of the basal 20 to 30 feet of the basin-fill deposits in the Catalina foothills indicate that they contain the same pebble types as the 
Rillito beds and are, therefore, difficult to distinguish on this basis. Most of the wells bottom in types II or III Rillito beds, but well (D-13-14)18cbcb apparently bottoms in type $I$.

\section{Canada del Oro Area}

The sample logs of six wells drilled in the Canada del Oro area are included in appendix A. Reconnaissance geologic mapping was conducted in this area to aid in the interpretation of the sample logs.

Four sedimentary formations were recognized and mappedQuaternary alluvium, terrace deposits, basin-fill deposits, and Rillito beds (pl. 1).

The Quaternary alluvium and terrace deposits, as seen in exposures and cuttings from well (D-11-14)10cac, contain a high percentage of quartzite boulders and stained quartz and granite. The quartzite apparently was brought in from the north.

The basin-fill deposits, as exposed east of Canada del Oro, are composed largely of pebbles of Catalina Gneiss and coarse-grained porphyritic granite. These deposits were laid down as alluvial fans, which spread out from the mouths of canyons along the northwest front of the Santa Catalina Mountains.

The Rillito beds appear to be correlative with the type III Rillito beds of the Catalina foothills. They lie unconformably below the basin-fill deposits and are in fault contact with the gneiss and granite 
of the northwest front of the Santa Catalina Mountains along the Pirate fault (fig. 43A). Immediately adjacent to the Pirate fault the Rillito beds consist of a coarse rubble of huge boulders (fig. 43B) but grade rapidly westward into a sandy gravel (fig. 44A). Immediately west of the coarse-grained porphyritic granite bedrock outcrops of Samaniego Ridge, the Rillito beds are composed exclusively of the erosion products of this porphyritic granite. Immediately west of the bedrock outcrops of the Catalina Gneiss, which forms Pusch Ridge, the Rillito beds are composed of erosion products of this gneiss.

The similarity between the pebble types in the basin-fill deposits and the underlying Rillito beds presents a problem in distinguishing between the two formations in well cuttings.

Geologic mapping near well (D-11-14)10cac indicates that the cuttings from this well below a depth of 40 feet represent the Rillito beds.

The sample logs of wells (D-12-13)2ccaa, (D-12-13)23dbc, and (D-12-13)23db show small amounts of quartzite and dark schist pebbles in the upper units of these wells that are absent in the lower units. This slight change in composition is tentatively interpreted as the contact between the basin-fill deposits and the Rillito beds.

The samples from wells (D-12-13)24cab and (D-12-13)26ccad are uniform in composition from top to bottom. The only change is a very slight difference in the color of the sand at depths of 90 and 160 


\section{FIGURE 43}

\section{THE PIRATE FAULT}

A.

Looking north at the Pirate fault exposed at the mouth of Alamo Canyon, SE-1/4 sec. 4, T. 12 S., R. $14 \mathrm{E}$. The fault separates Catalina Gneiss on the right from Rillito beds on the left.

B.

Coarse bouldery rubble of the Rillito beds near the Pirate fault. 

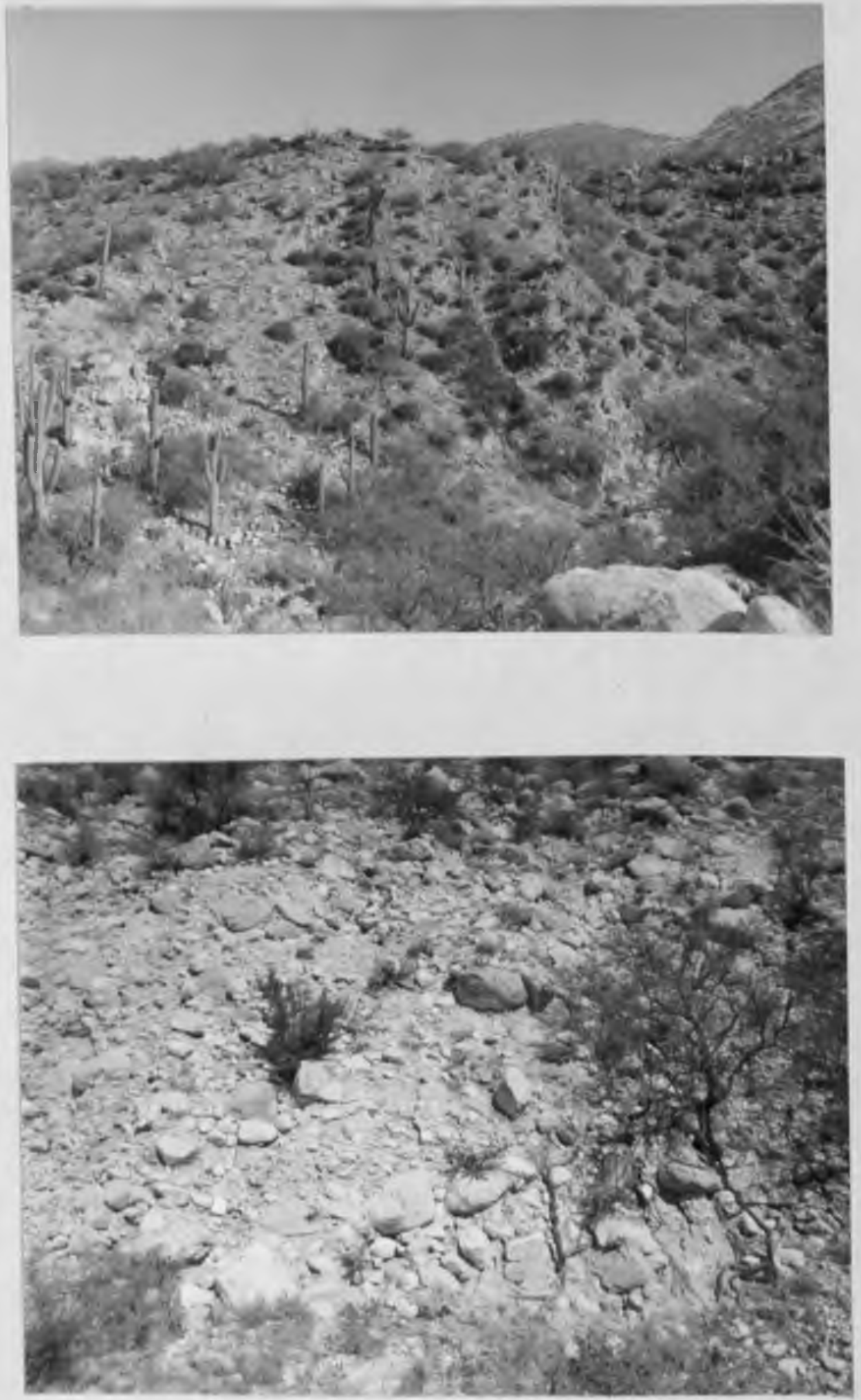
FIGURE 44

TYPE III RILLITO BED EQUIVALENTS

(Photo for fig. 44B by Jay Dusard)

\begin{abstract}
A.
Sandy gravel of the Rillito beds about half a mile west of the Pirate fault.
\end{abstract}

B.

Tilted and faulted conglomerate composed of volcanic pebbles. Exposure is in the Tucson Mountain foothills half a mile north of Speedway. 

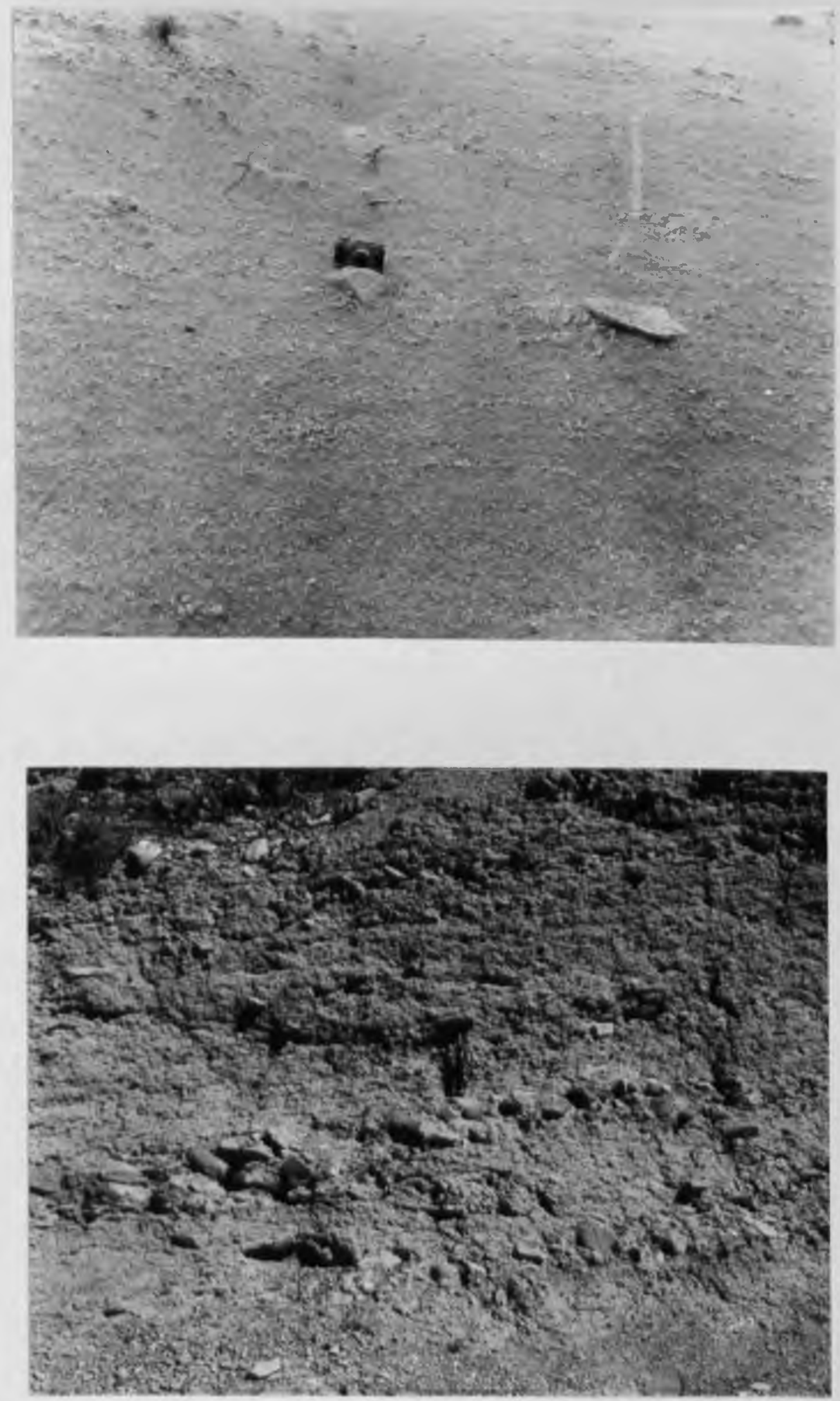
feet, respectively. It is difficult to interpret the color change as reflecting a major formation change.

\section{Sabino Creek Area}

The sample logs for six wells in the Sabino Creek area (pl. 4) are included in the appendix. The type III Rillito beds from wells (D-13-15)21abb, (D-13-15)28abd, and (D-13-15)29bac are composed predominantly of pebbles of Catalina Gneiss, with lesser amounts of quartzite, phyllite, and volcanic pebbles. They are very similar in appearance to the basin-fill deposits of the Rillito Creek area. Wells (D-13-15)32aab, (D-13-15)33bcb, and (D-13-15)33dbc all bottom in basin-fill deposits, which are composed predominantly of clean gneiss pebbles, and volcanic and phyllite pebbles are present in very minor amounts.

\section{Pantano Wash Area}

The sample logs of 23 wells drilled in the Pantano Wash area are included in appendix $A$. The contact between the basin-fill deposits and the underlying type III Rillito beds is very difficult to determine with certainty in this area because both formations are composed almost exclusively of sand and gravel composed of fragments of the Catalina Gneiss. In most instances the contact has been selected at 
the depth at which the percentage of exotic pebble types increases noticeably.

\section{Santa Cruz River Area}

The sample logs of 23 wells drilled in the Santa Cruz River area are included in appendix A. All these wells bottom in gravel or conglomerate composed of volcanic debris. The pebble types in this conglomerate do not resemble those in any of the formations mapped in the northern and eastern margins of the Tucson basin but are identical to those in a faulted and tilted conglomerate exposed in the Tucson Mountain foothills north of Speedway and west of Silverbell Road (fig. 44B). The bedding, sorting, cementation, and structure of these exposures resemble that of the type III Rillito beds of the Catalina foothills. The conglomerate probably is derived from erosion of the volcanic rocks of the Tucson Mountains and other volcanic ranges to the south.

In wells $(D-13-13) 9 \mathrm{bb}$ and $(D-13-13) 23 \mathrm{~d}$ the conglomerate contains pebbles of Catalina Gneiss and volcanic rocks. These well sites may represent an area where the drainages of the Catalina and Tucson Mountains merged during the time of deposition of the type III Rillito beds.

The basin-fill deposits in the Santa Cruz River area are composed predominantly of pebbles of the Catalina Gneiss in all wells as 
far south as the Benson Highway. South of the Benson Highway the basin-fill deposits are composed of pebbles of granite, quartz, volcanic rocks, and quartzite, all of which probably were derived from a southerly or westerly source.

The Quaternary alluvium along the Santa Cruz River is composed of pebbles of volcanic rocks and quartz and is easily distinguished from the underlying basin-fill deposits in well cuttings.

\section{Central Tucson Area}

The sample logs of four wells drilled in the central Tucson area are included in appendix A. These wells are not deep enough to penetrate the basin-fill deposits. The basin-fill deposits in these wells are composed of sand and gravel made up predominantly of gneiss debris.

\section{The Power Company Wells}

The Tucson Gas and Electric Co. drilled three deep exploration water wells with a rotary rig in secs. 2 and 3, T. 15 S., R. 14 E. (p1. 4). The sample logs of these wells are included in this report in appendix $A$; the logs show that similar stratigraphic sections were penetrated in all three holes.

The three wells-wells 5, 6, and 7-encountered relatively fine-grained deposits at depths of 660,570 , and 550 feet, respectively. 
Projection of the contour lines of plate 4 into the region of these wells indicates that this change could be interpreted as being the change from basin-fill deposits to Rillito beds. The change to fine-grained deposits was not accompanied by a significant change in pebble composition.

The most noticeable change in the pebble composition of the deposits in these wells occurred at depths of 1,840 feet in well 5, 1,850 feet in well 6, and 1,910 feet in well 7. Above these depths the pebbles are composed predominantly of Catalina Gneiss, quartz, and white feldspar. Pebbles composed of quartzite, volcanic rocks, and granite are present in minor amounts. Below these depths, pebbles of gneiss, quartz, and white feldspar are still important constituents, but in addition the percentage of pebbles composed of volcanic rocks, schist, and dark quartzite increases markedly. The increased hardness of the lower gravel is indicated by the increased frequency with which the drill bits were changed and by the use of the word "conglomerate" instead of "gravel" in the drillers' logs.

The pebble types in the hard unit appear to resemble those in the type III or type II Rillito beds of the Catalina foothills. 


\section{EVOLUTION OF THE TUCSON BASIN}

\section{Introduction}

Cenozoic rocks, structures, and erosion surfaces exposed in the northern, eastern, and central parts of the Tucson basin preserve a fairly complete record of the geologic evolution of the basin. The structures and rocks of the mountains preserve a record of early to middle Tertiary folding, metamorphism, intrusion, and thrust faulting, which initiated mountain uplift and produced the structures that control the shape of the basin. The stages of the uplift and erosion of the Santa Catalina, Tanque Verde, and Rincon Mountains are recorded in the lithology of the Rillito beds. Late Tertiary deformation, which had little effect on the outline of the basin, is recorded in the form of tilted fault blocks of Rillito beds. A period of extensive erosion, which included the formation of narrow hard-rock pediments along the edges of the mountains, is recorded in the form of the Rillito surface, which bevels the Rillito beds and their structures. The record of a period of deposition within a closed basin is preserved in the form of the structurally undeformed basin-fill deposits. The record of several cycles of degradation, probably as the result of the interior drainage of the 
basin obtaining an outlet to the northwest, is preserved as a series of narrow river terraces and broad erosion surfaces carved across all the rocks of the piedmont area. This erosional stage in the evolution of the Tucson basin is still in progress.

\section{Early and Middle Tertiary Deformation}

Although sediments of early Tertiary age have not been identified along the northern and eastern margins of the Tucson basin, folding, thrust faulting, intrusion, and metamorphism that probably began in the early Tertiary and continued into the middle Tertiary produced structures that profoundly affected the eventual configuration of the basin. This deformation produced the Catalina Gneiss, its folds, and the Catalina fault and resulted in the uplift of the Santa Catalina, Tanque Verde, and Rincon Mountains. Subsequent faulting in late Tertiary time and erosion in late Tertiary and Quaternary time was strongly controlled by and tended to emphasize the early to middle Tertiary folds and the Catalina fault.

\section{Middle and Late Tertiary Uplift, Erosion, Deposition, and Faulting}

The type I Rillito beds, the oldest Cenozoic deposits exposed along the northern and eastern margins of the Tucson basin, record the very early stages of the uplift and erosion of the mass of Catalina Gneiss that forms the Santa Catalina, Tanque Verde, and Rincon 
Mountains. The type I Rillito beds were deposited by westerly flowing streams that emptied into standing bodies of water in which deposits of gypsum and red mudstone were accumulating. These streams appear to have originated northeast, east, and southeast of and within the area now occupied by the Santa Catalina, Tanque Verde, and Rincon Mountains. Although these ranges did not exist in their present form, local highlands or centers of uplift were present within the boundaries of the present ranges and supplied detritus, including pebbles of the Catalina Gneiss, to the basin of deposition of the type I Rillito beds. The margins of the basin of deposition included areas now located within the range boundaries and extended to the edges of the then existing highlands.

The deposition of the type II Rillito beds took place during continued uplift and erosion of the highlands that existed within the boundaries of the present ranges. Erosion cut increasingly deeper into the rising highlands, stripping their mantle of quartzite, limestone, and volcanic rocks and exposing increasingly larger areas of their cores of Catalina Gneiss. The area covered by the rising highlands increased, and previously deposited type I Rillito beds were locally involved in the uplift and subjected to erosion; these erosion products were redeposited with the type II Rillito beds along the margins of the highlands. Lakes that existed during the deposition of the type I Rillito beds were destroyed by the spreading uplift or filled in 
by the increasingly coarse gravels of the type II Rillito beds.

By the time of deposition of the type III Rillito beds, the Santa Catalina, Tanque Verde, and Rincon Mountains had obtained a configuration similar to their present one, except that their fronts were located slightly mountainward of their present position. West-flowing streams. that had their source areas east, northeast, and southeast of the mountains during the deposition of the type I and type II Rillito beds had these source areas blocked off by the uplift of the mountains in their path. The source area for the type III Rillito beds was now entirely within the mountains. The Catalina Gneiss was the dominant rock type exposed in the source area, but other rock types, including the earlier deposited Rillito beds, were also present in lesser amounts. The type III Rillito beds were deposited as large alluvial fans that spread basinward from the fronts of the ranges and graded into increasingly finer grained deposits in the center of the basin. These fine-grained deposits are interbedded with anhydrite and gypsum, indicating that an extensive playa existed in the central part of the basin. Alluvial fans also spread basinward from the edges of the Empire, Santa Rita, Sierrita, and Tucson Mountains and merged with the finegrained deposits in the central part of the basin.

The close of deposition of the type III Rillito beds was marked by normal faulting, which broke the Rillito beds into a series of tilted blocks. Renewed movement along the Catalina fault depressed these 
fault blocks with respect to the rocks of the mountains. The normal faulting that affected the Rillito beds of the piedmont area did not extend across the Catalina fault into the Catalina Gneiss of the ranges, which acted as one massive block following its original time of metamorphism and folding. Thus, the configuration of the ranges and, therefore, of the basin was controlled by the outcrop configuration of the west-southwest-trending and plunging folds of the Catalina Gneiss and by the Catalina fault, which is parallel in strike and dip to the limbs of the underlying folds.

Late Tertiary and Early Quaternary Erosion and Deposition

Although the normal faulting that preceded the deposition of the basin-fill deposits undoubtedly affected the drainage pattern within the basin and determined the location of the deepest part of the basin, erosion that took place simultaneously with or subsequent to the faulting destroyed any trace of fault-block topography that may have existed in the piedmont area. This erosion carved the broad gently sloping Rillito surface across the relatively soft Rillito beds and carved narrow bedrock pediments across the hard rocks of the mountains. The configuration of the Rillito surface indicates that its formation and the subsequent or simultaneous deposition of the basin-fill deposits on the surface took place in a closed basin. During and after its formation, the Rillito surface was buried by coarse-grained alluvial fans, which 
extended from the steep fronts of the Santa Catalina, Tanque Verde, and Rincon Mountains to the center of the basin where they graded into finer grained deposits. Similar alluvial fans spread basinward from the Empire, Santa Rita, Sierrita, and Tucson Mountains and merged near the central part of the basin.

\section{Middle and Late Quaternary Basin Erosion}

The middle and late Quaternary has been a time of degradation within the Tucson basin. Streams that had been depositing sediments within the basin during basin-fill time now began to cut into the basin sediments and to transport the resulting erosion products out of the basin. This degradation within the basin may have been initiated by the interior drainage of the basin obtaining an outlet to the northwest. This would have resulted in increased stream gradients within the basin and produced erosion upstream from the basin outlet. Rillito Creek was established slightly south of its present position, perhaps by headward cutting that originated at the newly formed basin outlet, and gradually captured the headwaters of streams that formerly drained to the interior of the basin. Several cycles of downcutting and lateral erosion occurred and produced the Cemetery and Jaynes terraces, the present flood plains, and the broad erosion surfaces that bevel the rocks of the piedmont area. This erosion exhumed the bedrock pediments along the 
mountain edges, uncovered the Rillito beds, and removed the basin-fill alluvial fans from large areas adjacent to the mountain front.

The modern streams are still in the process of eroding the basin deposits and transporting them out of the basin. 


\section{APPENDIX A-WELL-CUTTINGS ANALYSES}

This appendix contains the descriptions and analyses of the formation cuttings collected from 105 wells in the Tucson area. Drillers' logs were included, if they were available, in order to permit comparison of the lithologies described by the drillers with the rock units recognized during the laboratory analysis of the formation samples.

The samples studied consisted of unwashed cuttings collected by the drillers at 10-foot vertical intervals. The percent fines (particles less than $0.0625 \mathrm{~mm}$ in diameter) was determined by wet sieving the samples and estimating the percent of the total sample lost. The color was determined by comparing particles of sand size with Munsell Soil Color Charts (1954). Pebble types were determined by examining the gravel-size particles remaining in the washed sample. The word exotics was used in many descriptions to describe rock types other than the Catalina Gneiss.

The following symbols are used on the sample logs:

Qtd and Qtg = terrace deposits

$$
\text { Qal = Quaternary alluvium }
$$

$\mathrm{QTbf}$ and $\mathrm{TQbf}=$ basin-fill deposits

Trb, I, II, III = Rillito beds, types I, II, or III 


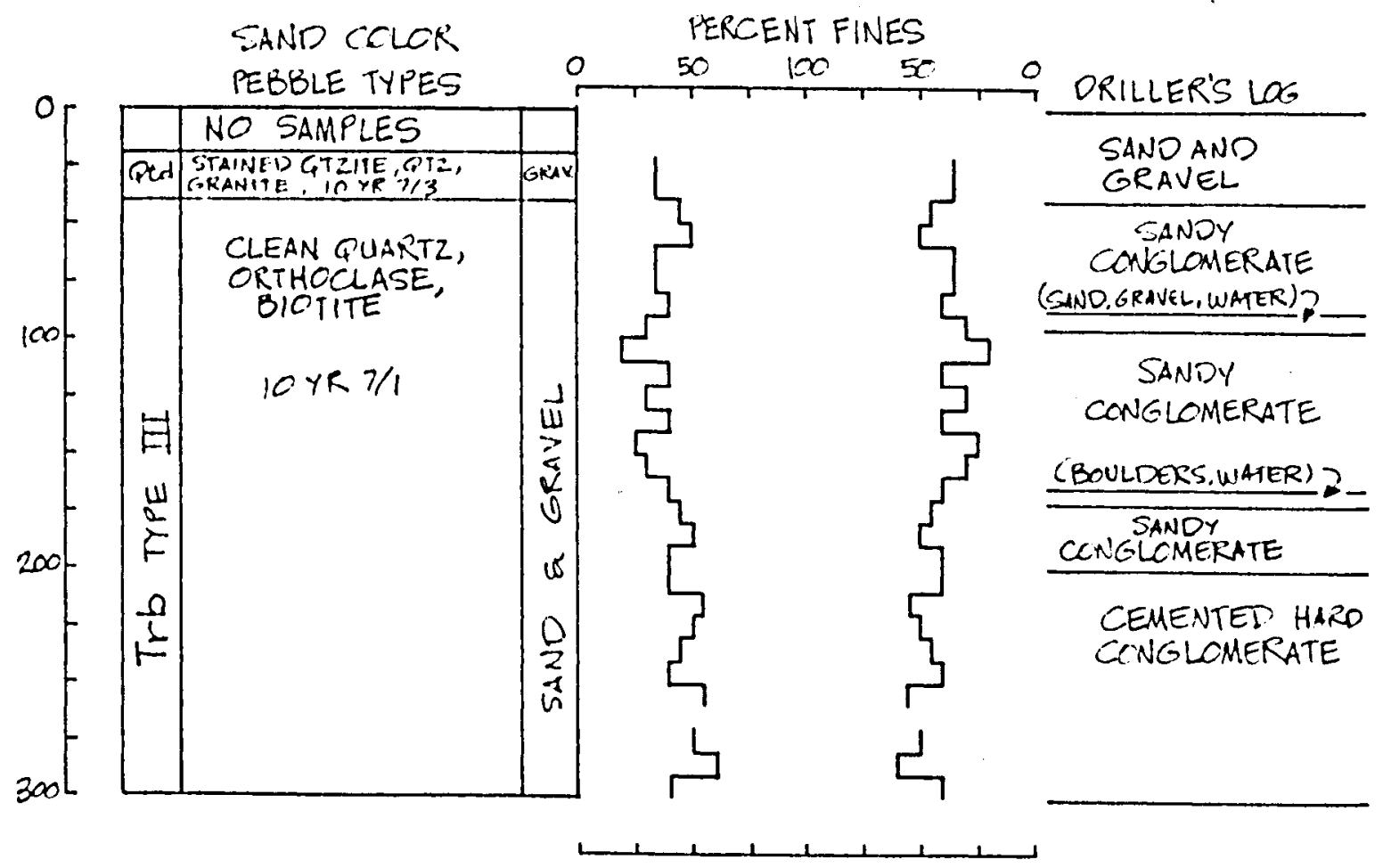

LOCATION OWNER

DRILLING CO.

ORILLER

LAB. NO.

DATE DRILLED

WATER. LEVEL

SURFACE EXPOSURE
$(D-11-14) 10 \mathrm{cac}$

R. CLEBERG

FORSYTH

LENIONS

2175

JUNE, 1965

$85^{\circ}$ JUNE 65

atd 


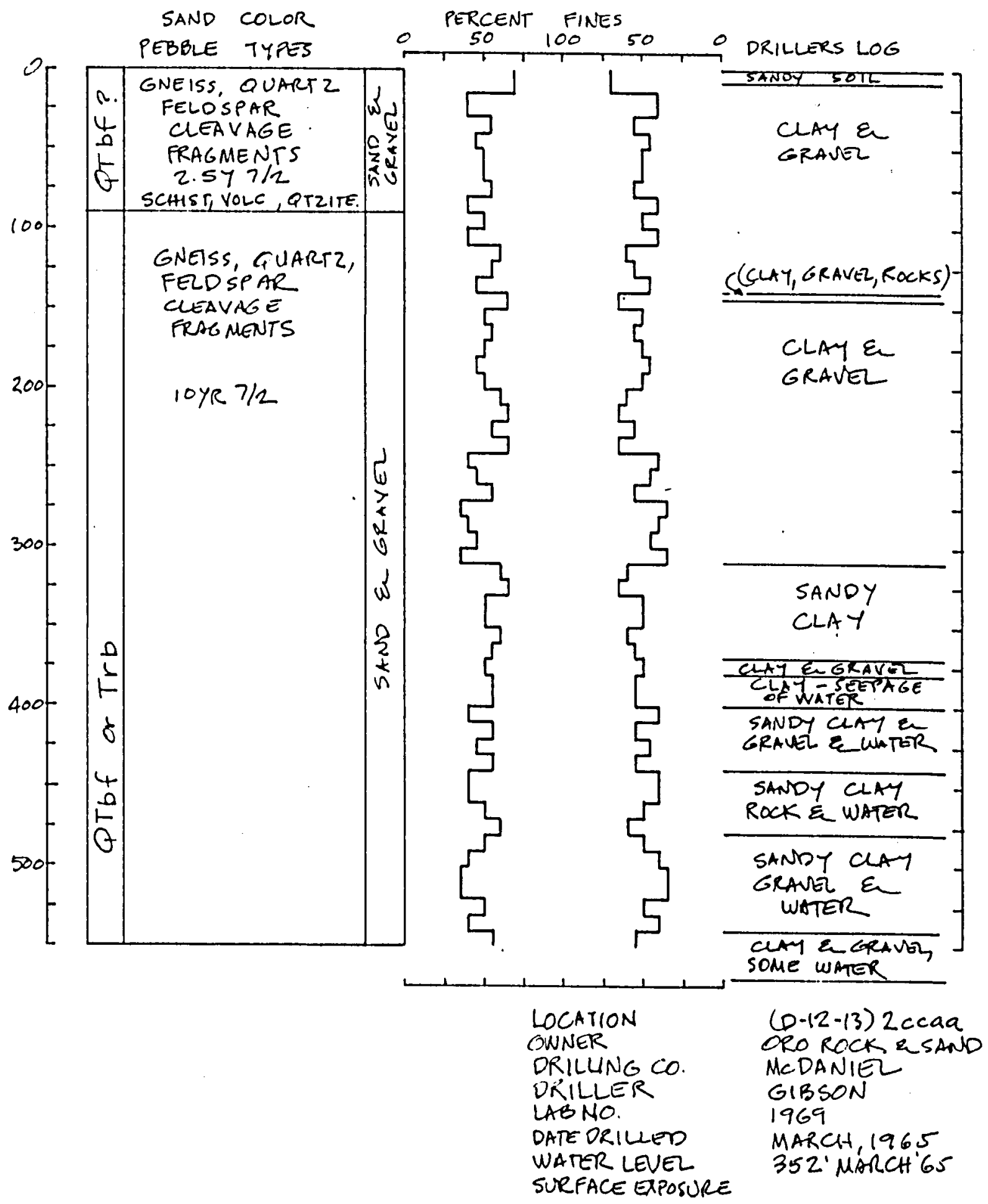




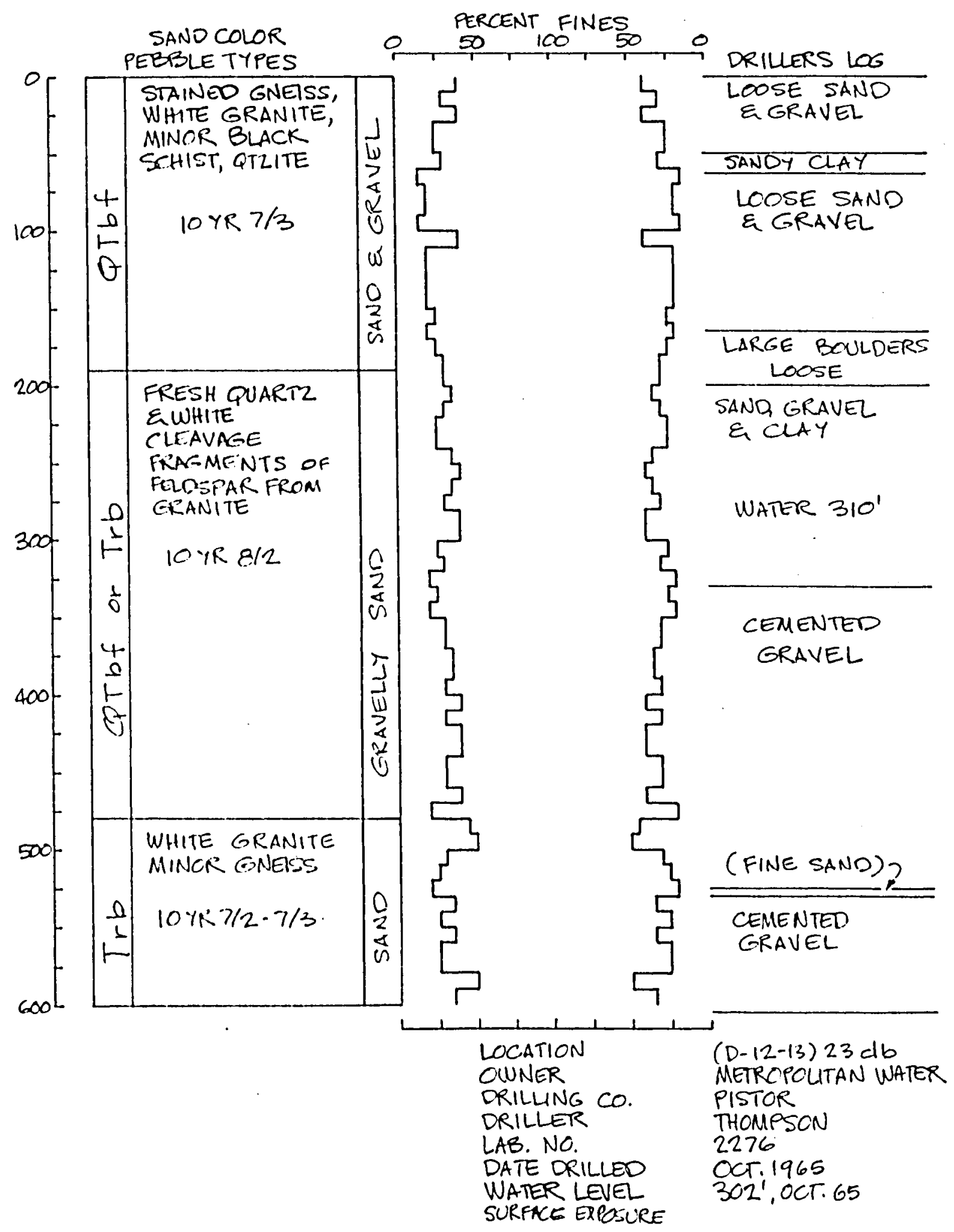




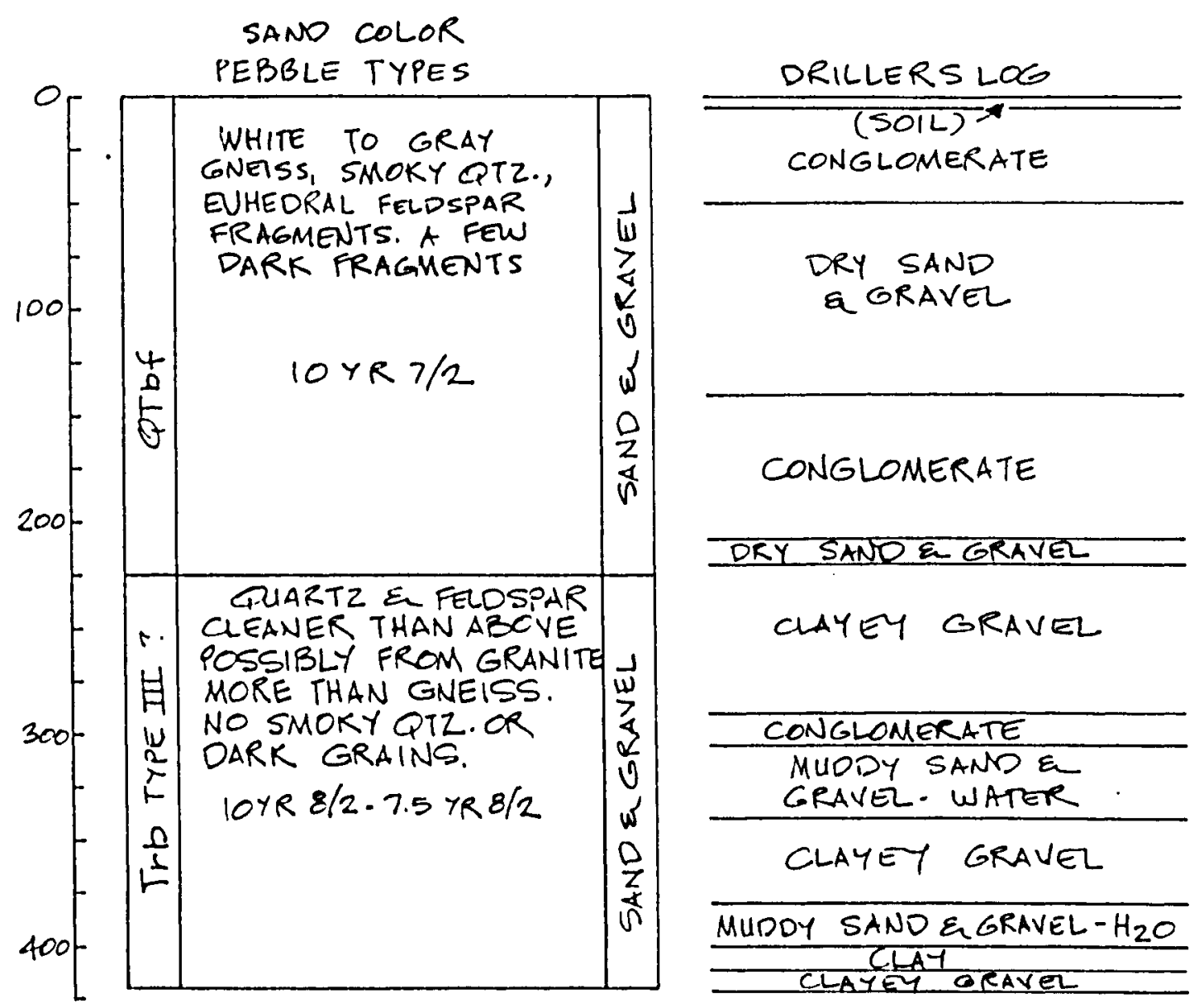

LOCATION OWNER

DRILUING CO.

DRILLER

LAB. NO

DATE DRILLED

WATER LEVA

SURFACE EXPOSURE
$(0.12-13) 23 \mathrm{dbc}$

KENNEDY

MCDANIEL GIBSON 1376 OCT. 1961 $293^{\circ}$ OCT 61 


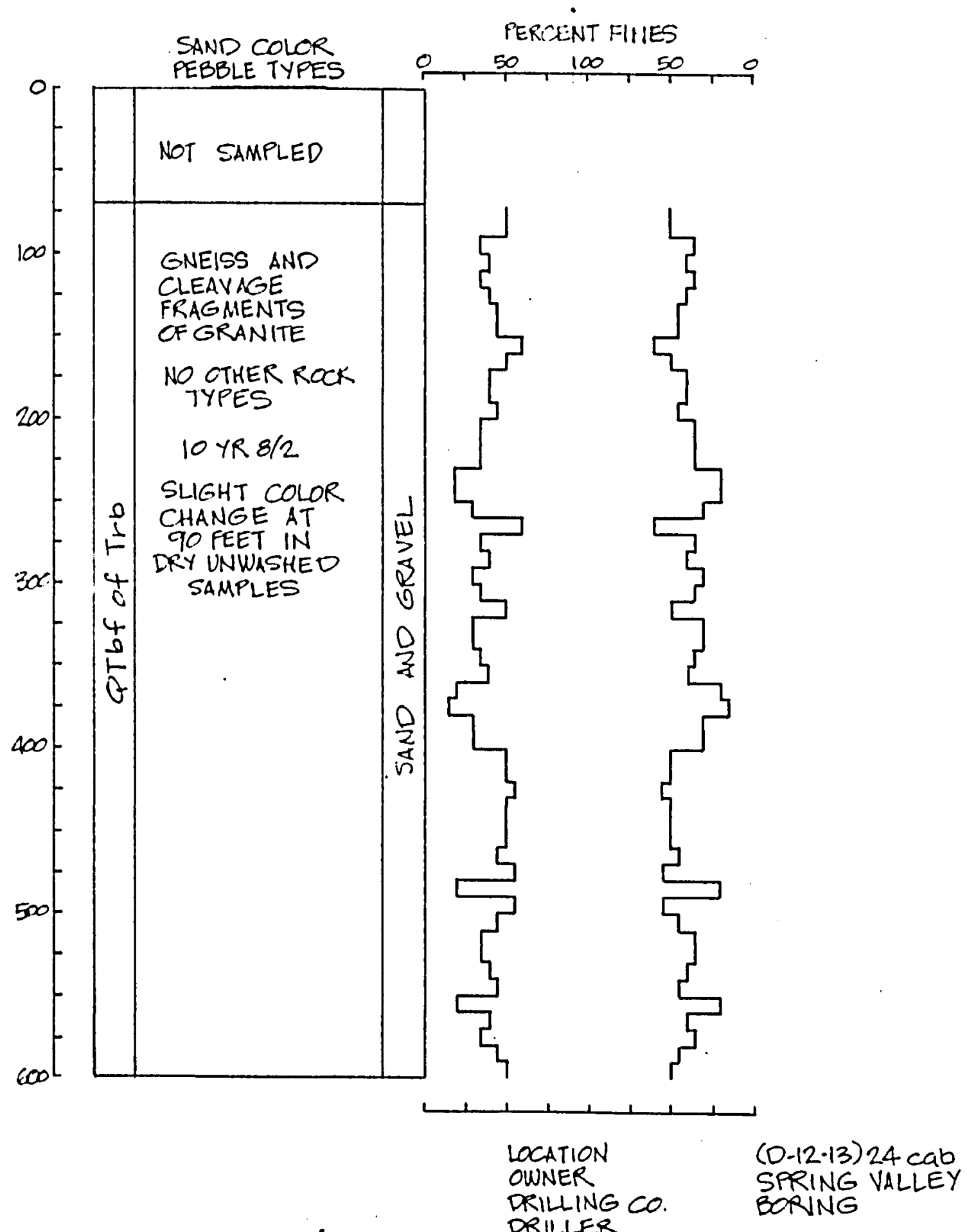

DRILLER

LAB. NO.

DATE DRILLED

WATER LEVEL

SURFACE EXPOSURE

1967

1965

$311^{\prime}$, NOV 65 


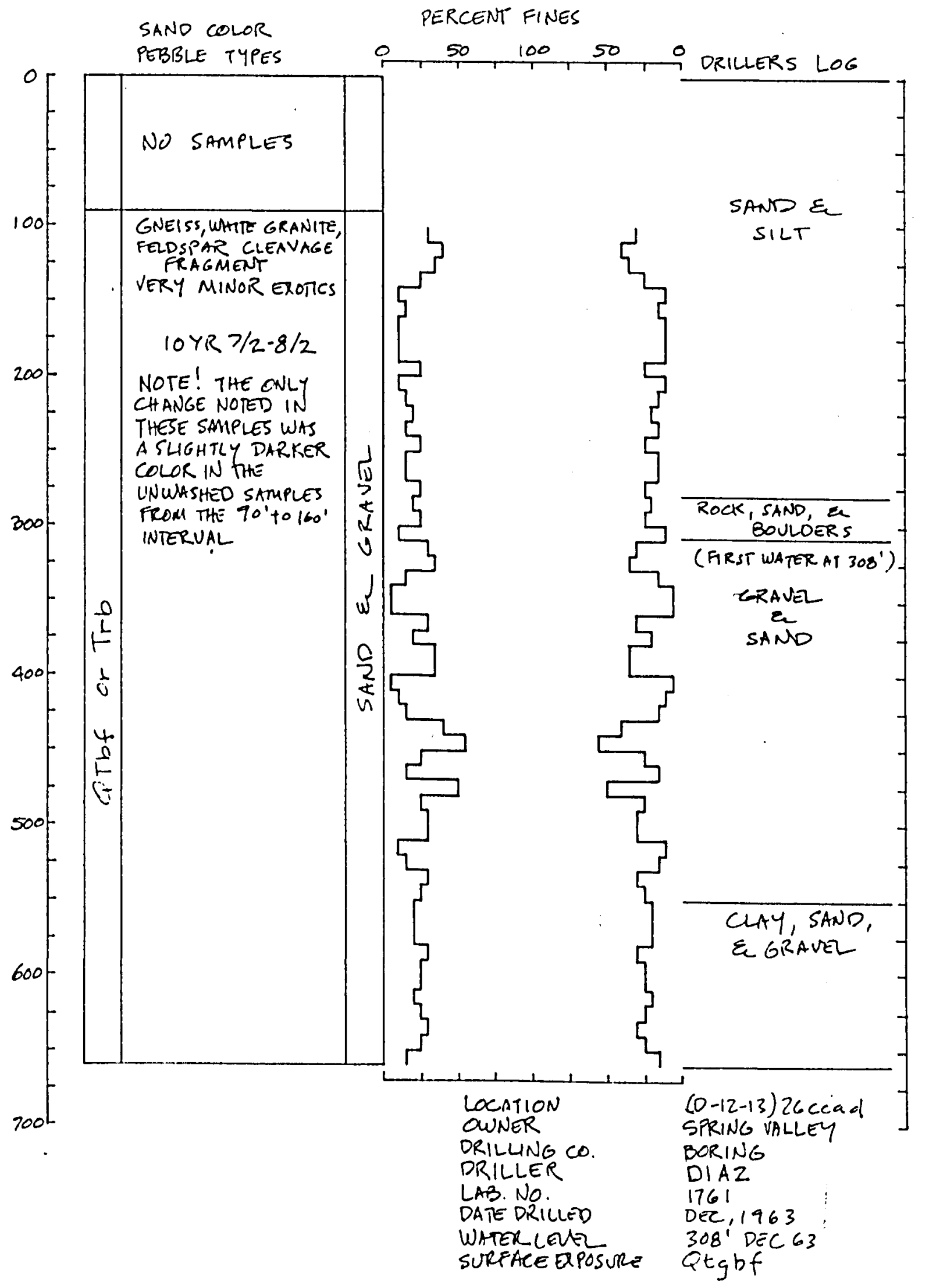




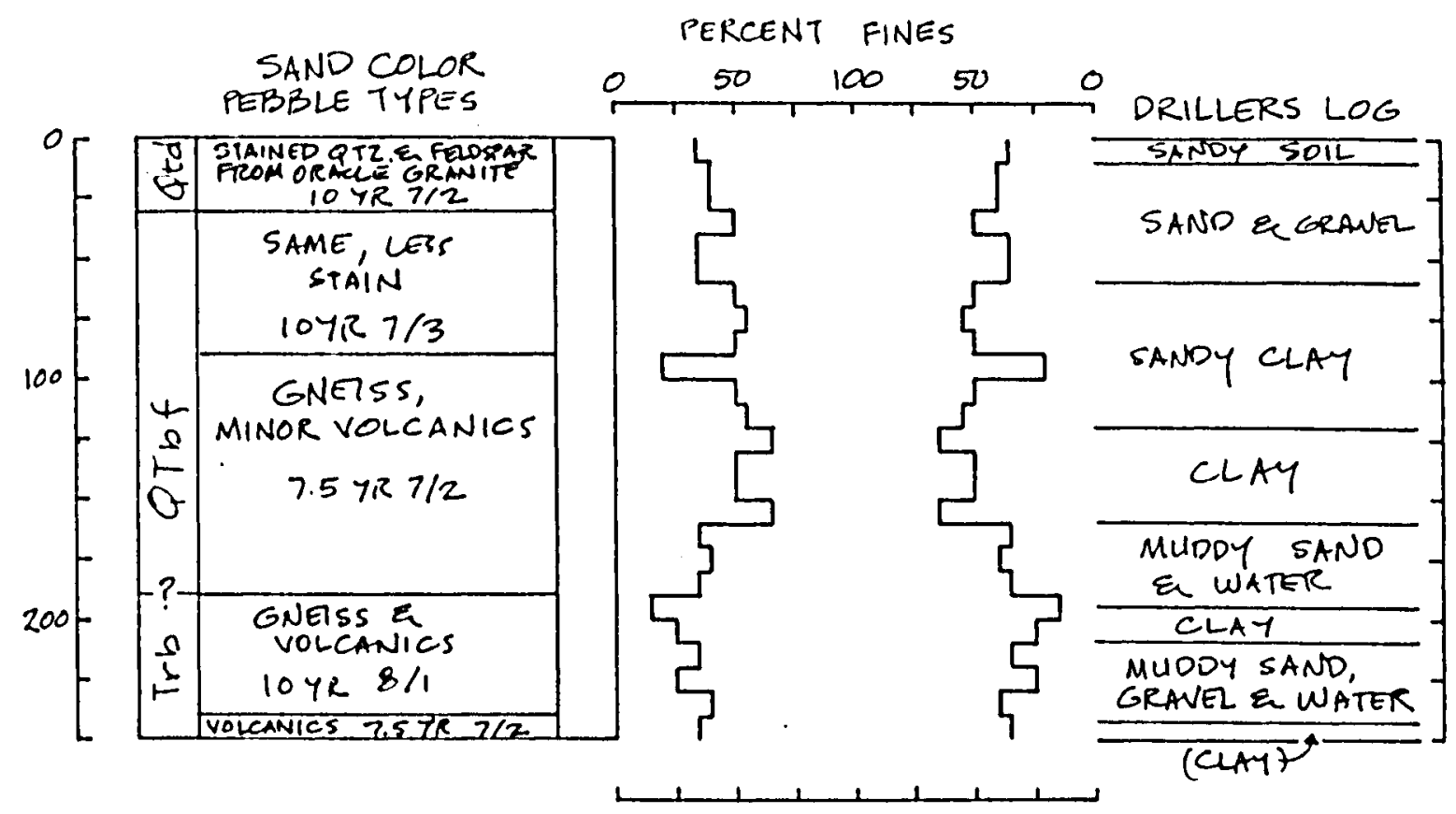

LOCATION

CWNER

DRILLINGCO

DRILLER

LAB.NO.

DATE DRILLED

WATER LEVEL

SURFACE EXPOSURE
$(0-13-13) 9$ bb

VAUGHAN

MCDANIEL

GIBSON

2183

JULY, 1965

$148^{\prime}$, JuLy 65 


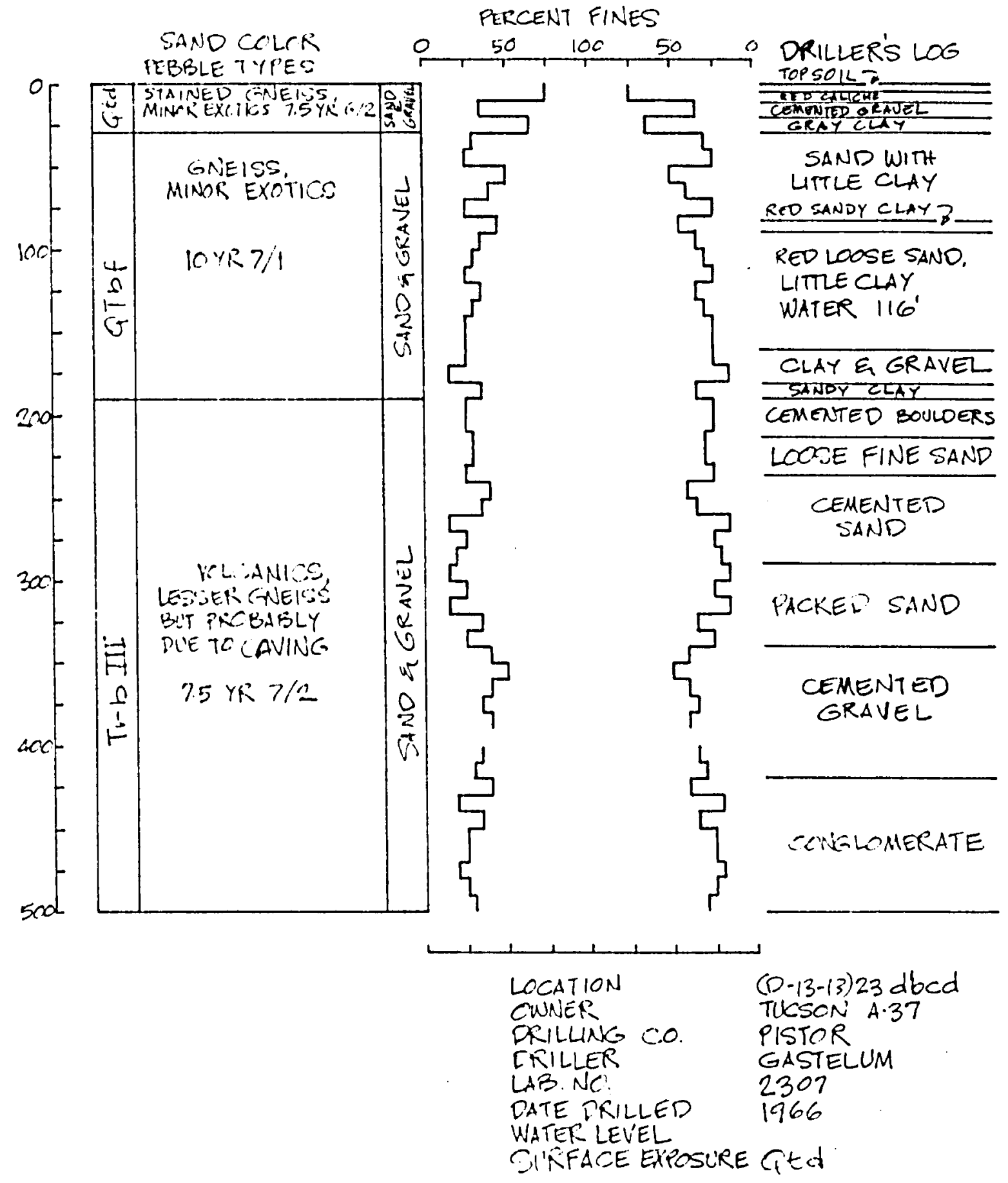




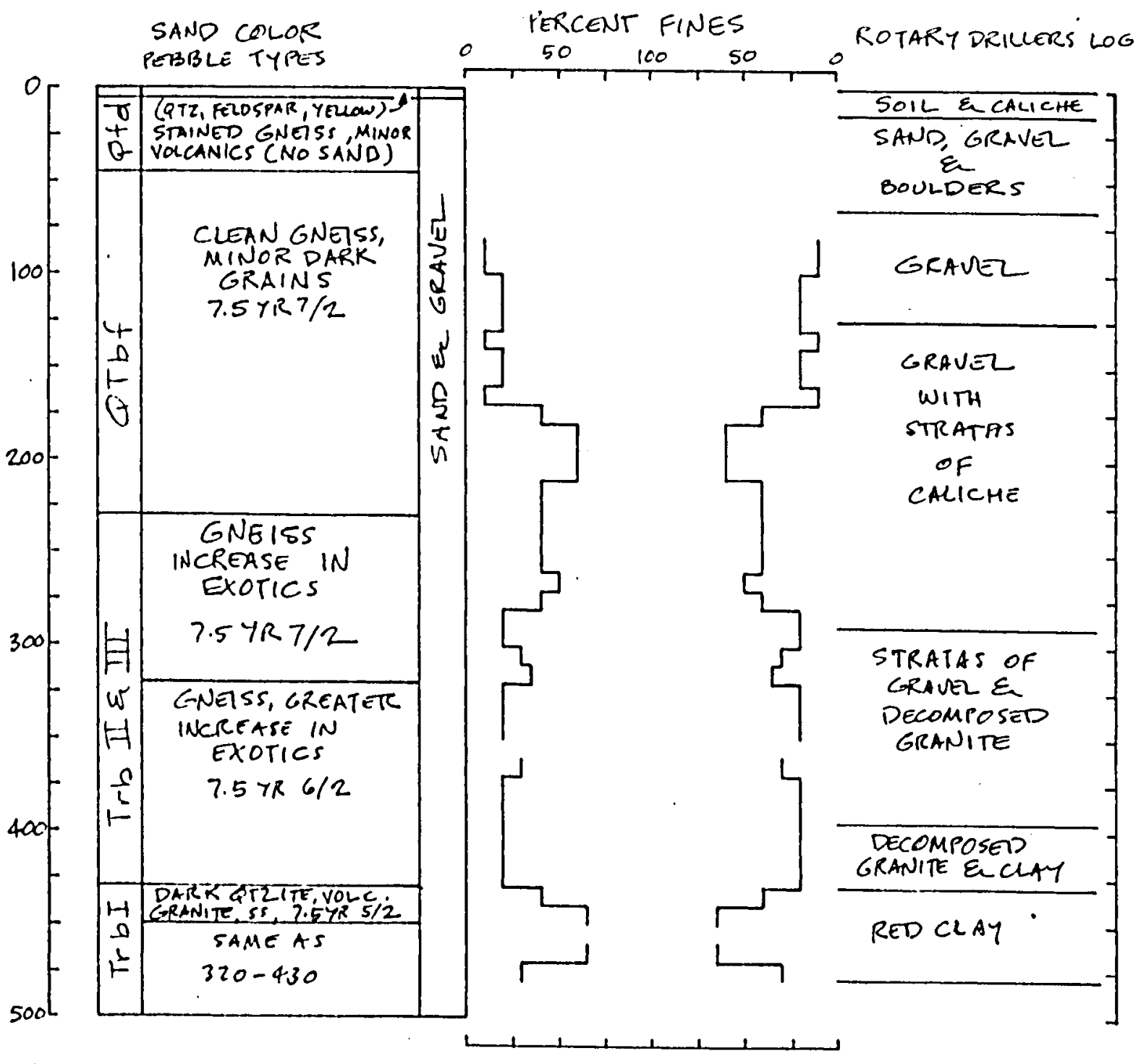

LOCATION OWNER

DRILLING CO.

ORILLER

LAB.NO.

DATE ORILLEO

WATER LEVEL

SIRFACE EXPOSURE
$(0-13-13) 25$ abba.

TUCSON A 36

L.P. CROMER

1995

Mry 1965

96 MAY or

ptg 


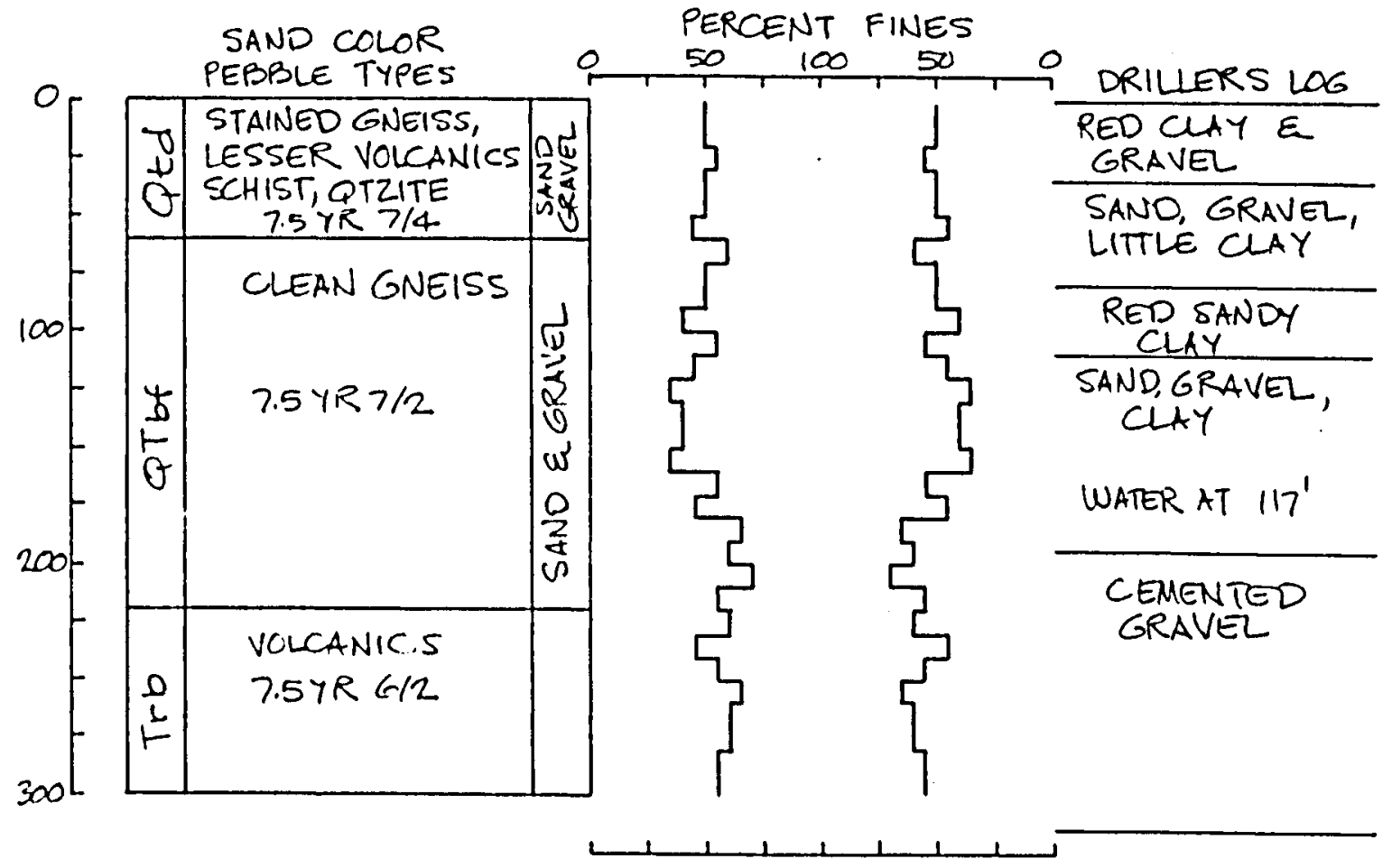

LOCATION OWNER

DRILUNGG CO.

DRILLER

LAB.NO.

DATE DRILED

WATER LEVEL

SURFACE EXPOSURE
$(0-13-13) 25 c d c c$ SAWTEL WATER CO. PISTOR THOMPSON 2180 JuLY, 1965 $112^{\prime}$, JuLY' 65 


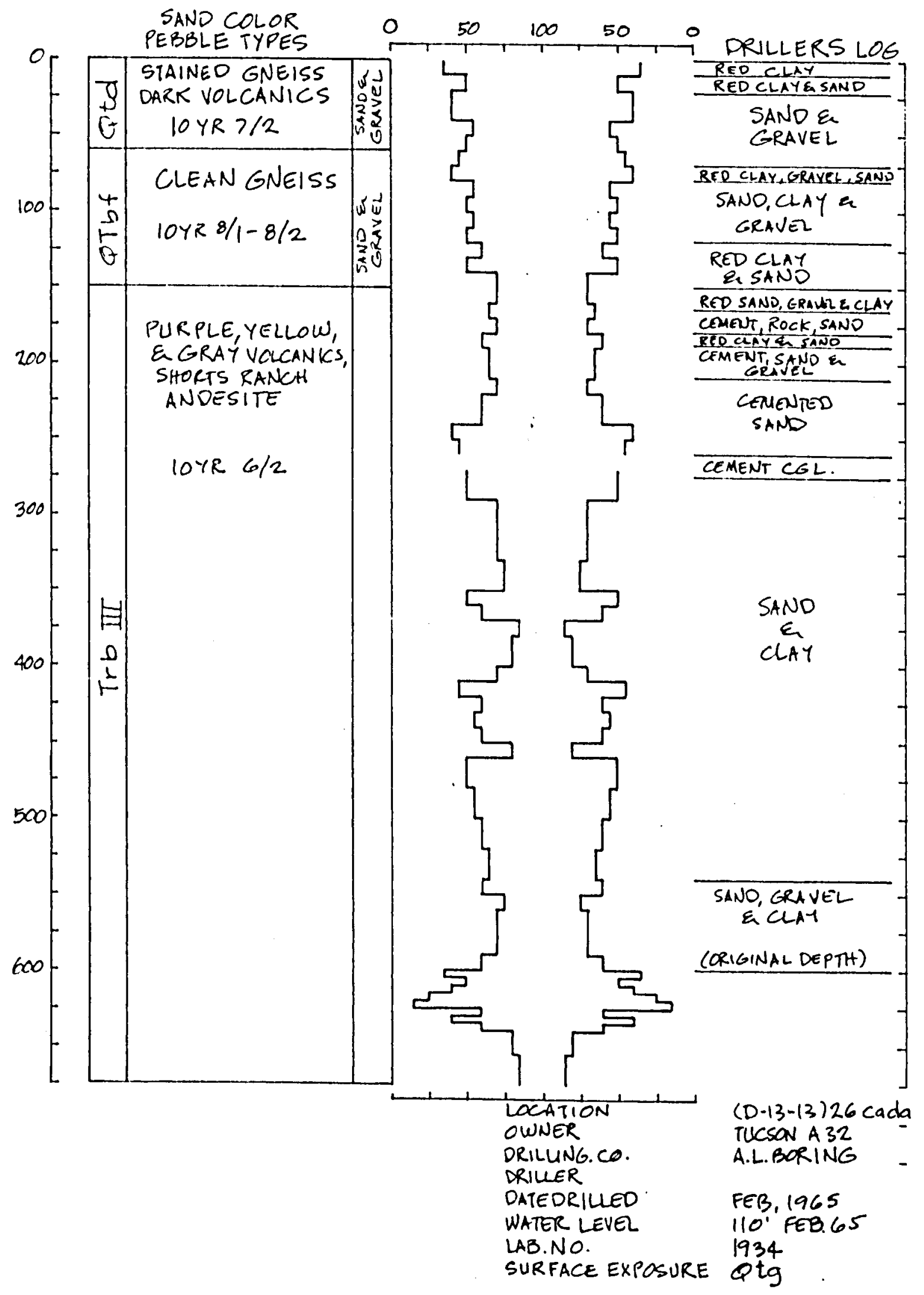




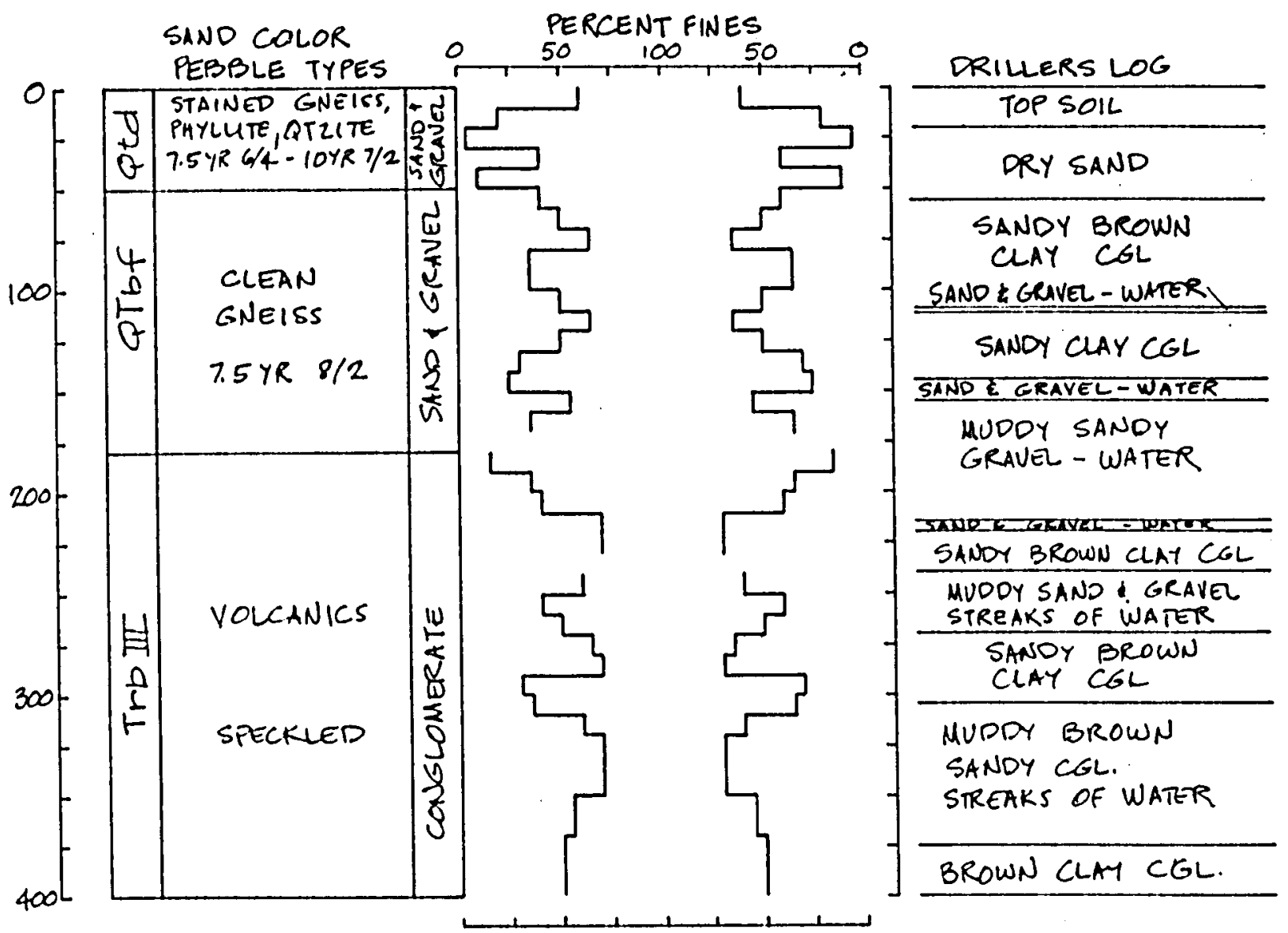

LOCATION OWNER

DRILUNG CO.

RRILLER

LAB.NO.

DATE DRILLED

WATER level

SURFACE EXPOSURE
(D.13-13)26 dacd HOLYHOPE CEM.

FORSYTH

BANGHART

1806

MARCH, 1964

$106^{\prime}$ APRIL, 1964

Qtg 


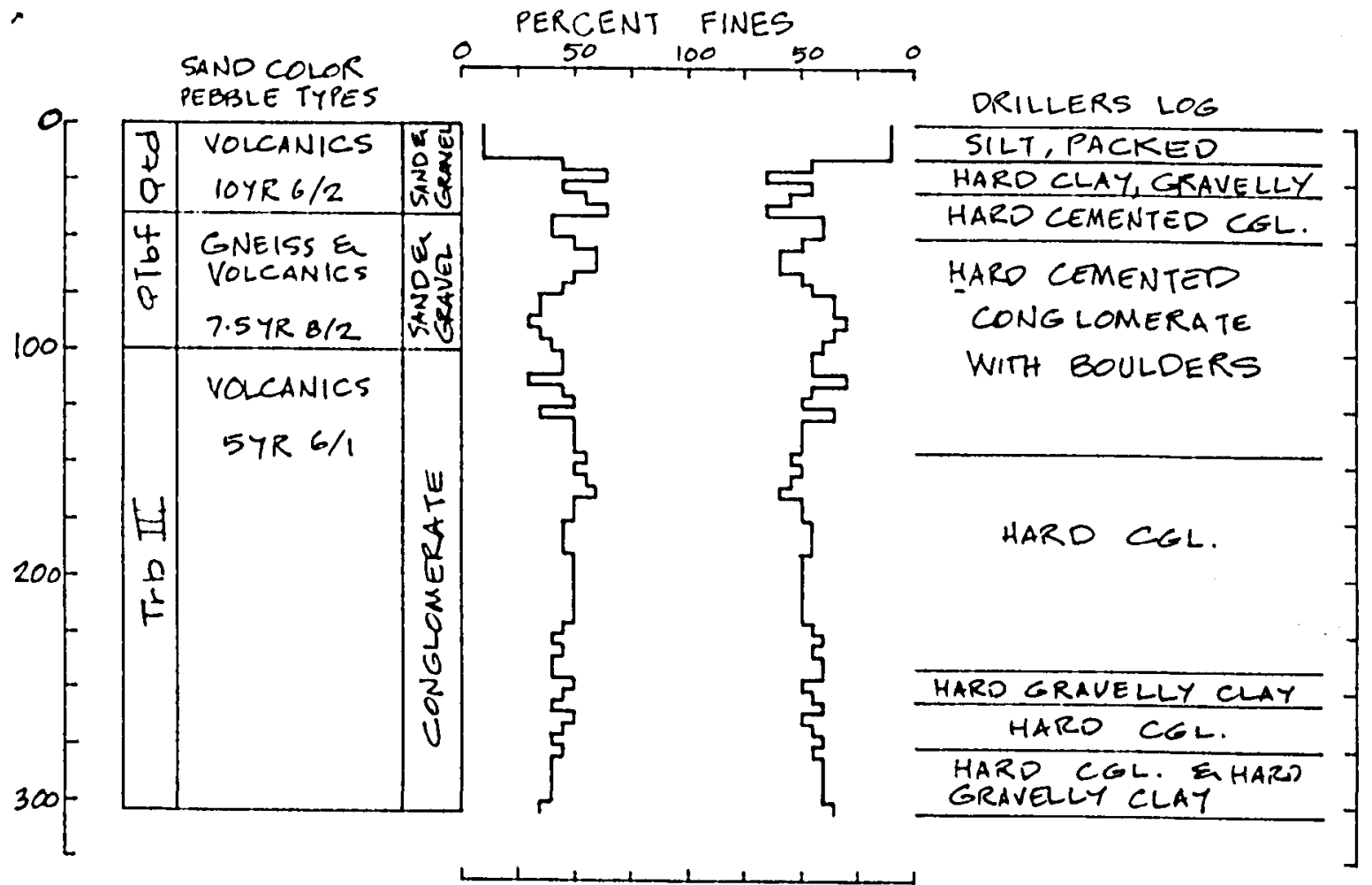

LOCATION OUNER

ORILLING CO.

DRILLER

LAB. NO.

DATE ORILLED

WATER LEVEL

SURFACE EXPOSURE
$(0-13-13) 27 \mathrm{cdd}$ SOIL CONSERVATION WESER

1567

MARCH 1963

$82^{\circ}$ Nar 63

Qtg 


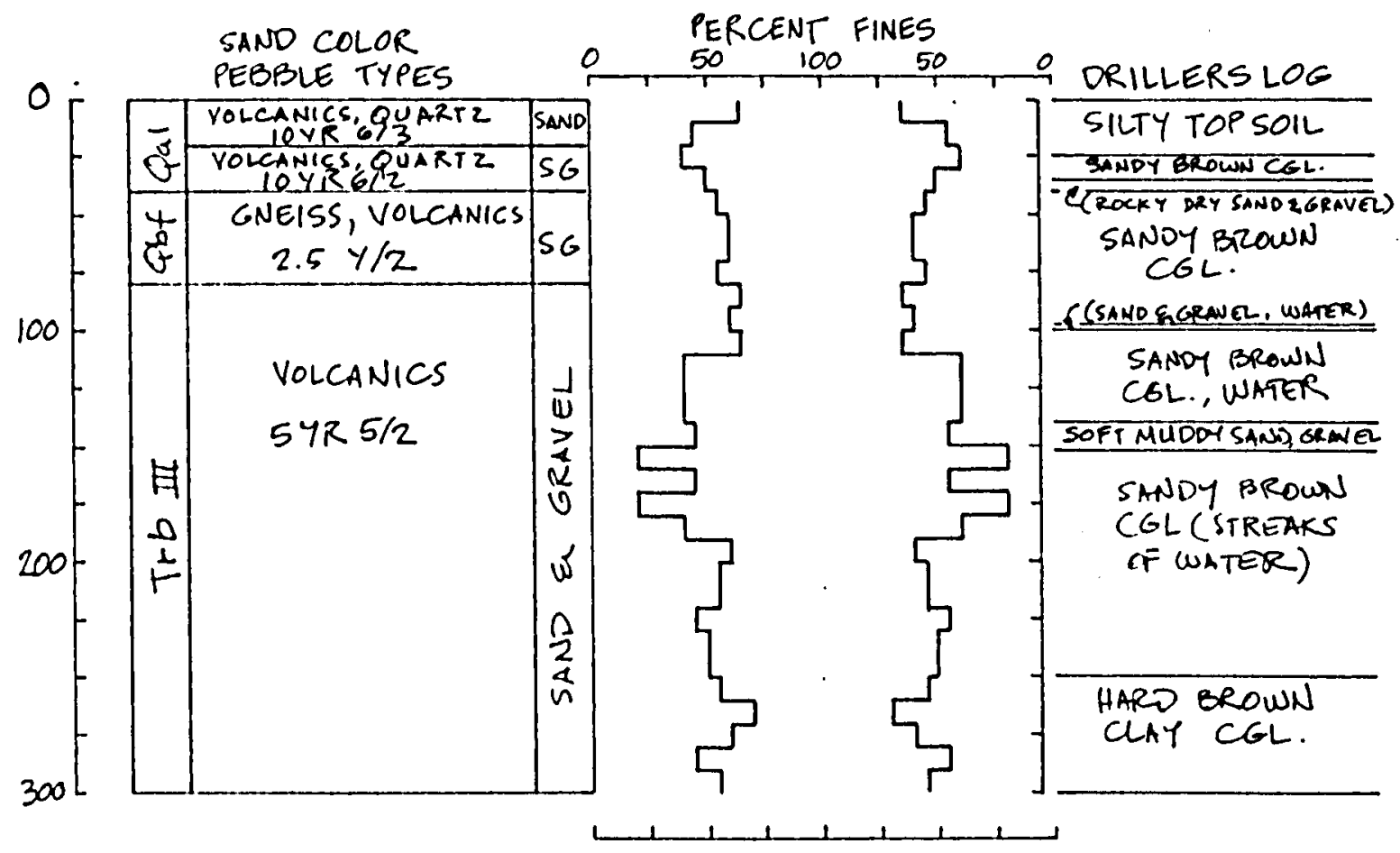

LOCATION

OWNER

DRILLINGCO.

DRILLER

LAB.NO.

DATE DRILLED

WATER LEVEL

SURFACE EXPOSURE
(D-13-13) 34 baa

U of A WILDLIFE

FORSYTH

BANGHART

2174

JULY, 1965

$88^{\prime}$ JuL 7,65 


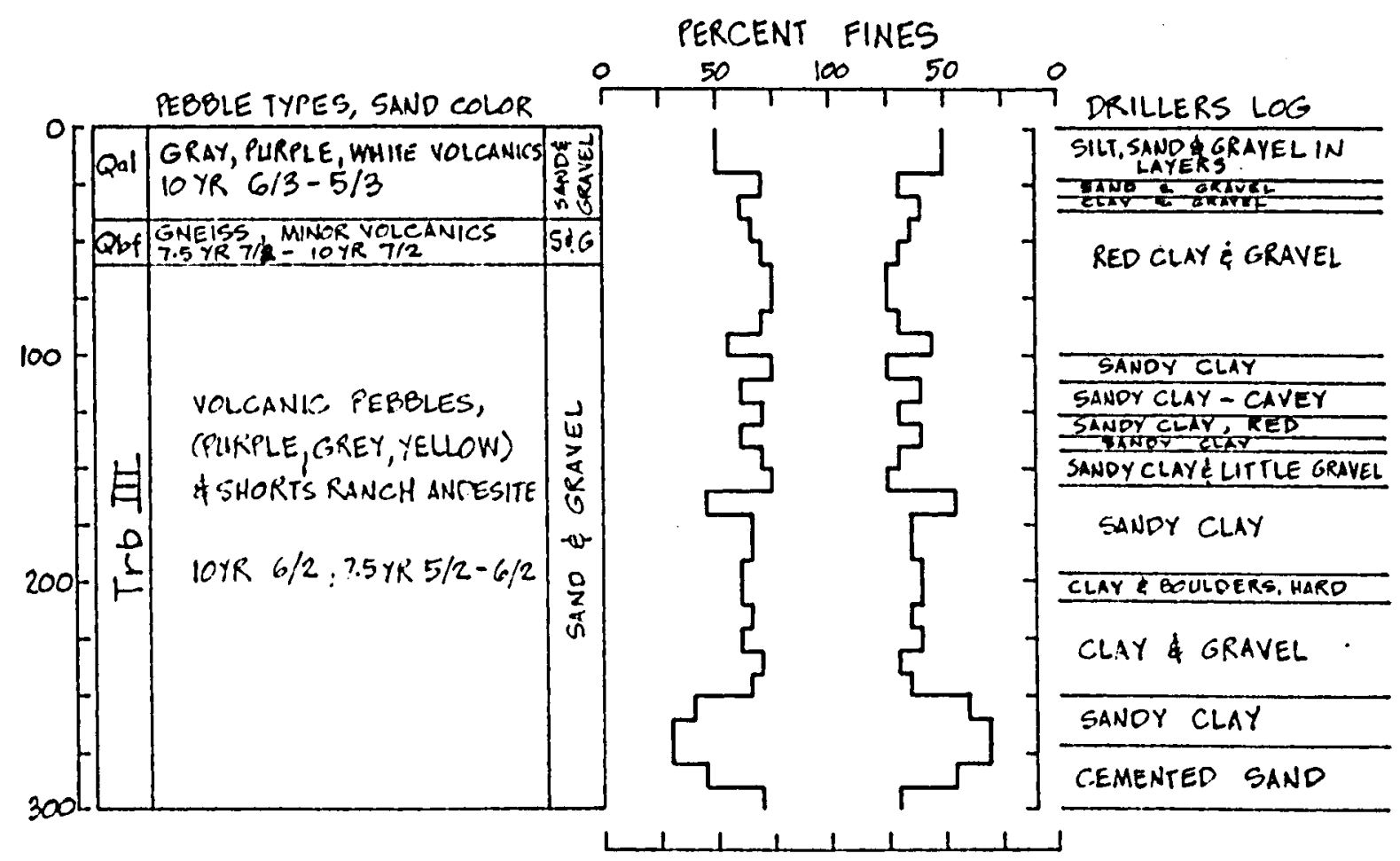

LOSATION

OWNER

ORILLING CO.

ORILLER

$L A B$. NO.

DATE CRILLED

WATER LEVEL

SURFACE EXPOSURE
$(0-13-13) 34 \mathrm{bdc}$

UNIV OF ARIZONA

CARL PISTOR

E. GASTELUM

1936

FEB, 1965 


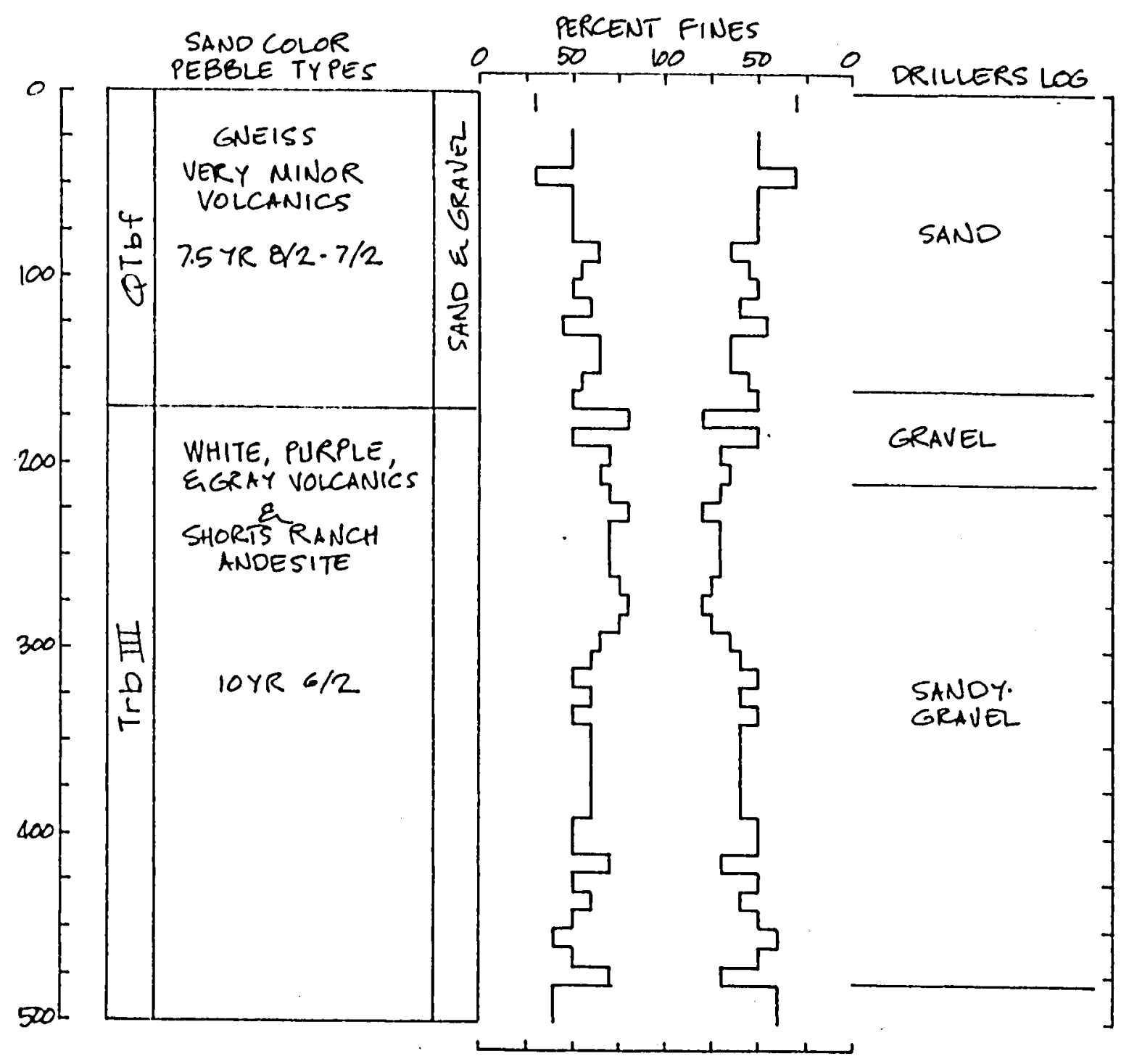

LOCATION OWNER

$(0-13-13) 35 a d b$

DRILLINGCO.

DRILLER TUCSON A-35

LAB. NO.

A.L.BORING DIAZ

DATE DRILLED

WATER LEVEL 1941

MARCH 1965

SURFACE EXPOSURE $125^{\prime}$ MAR. 65 Qbf 

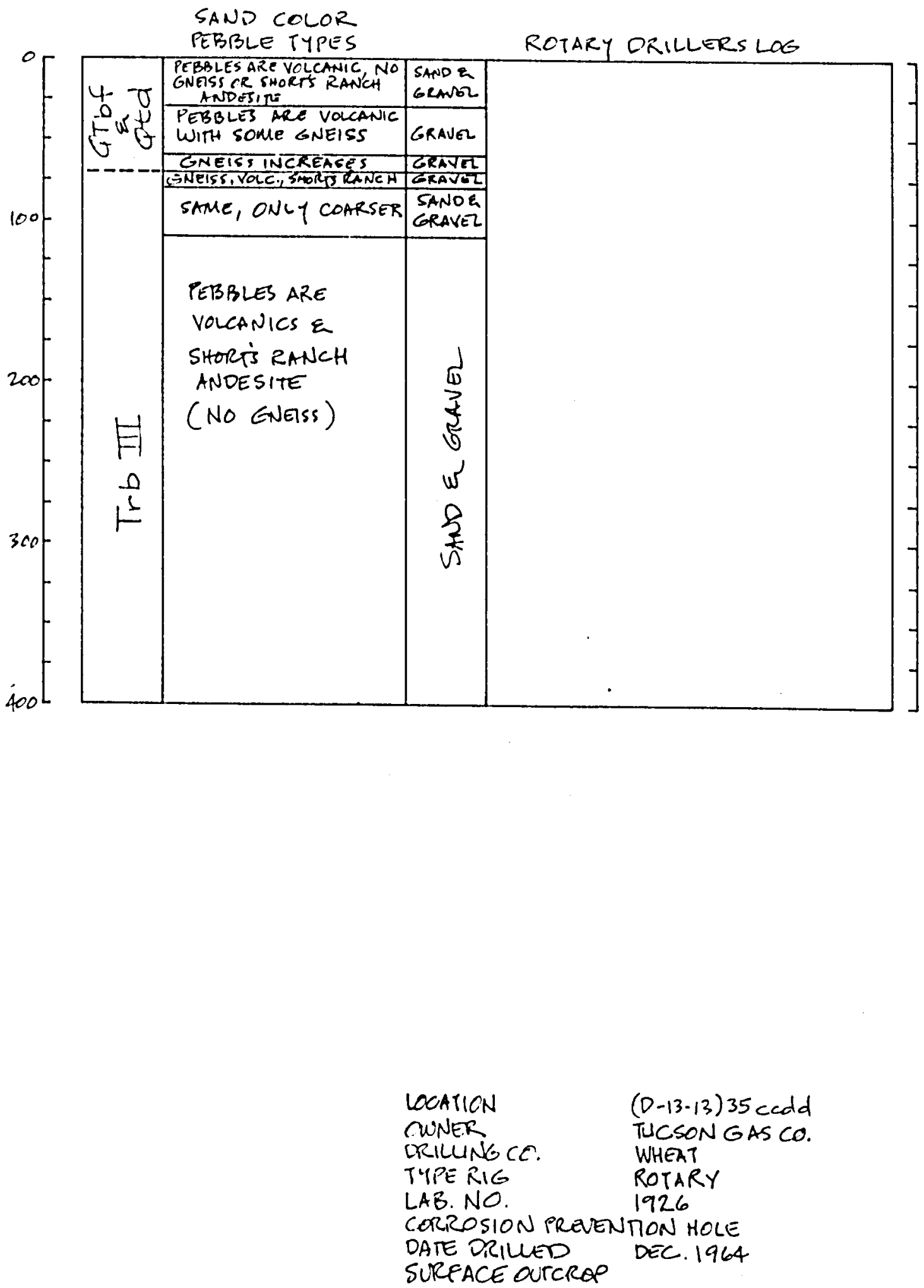

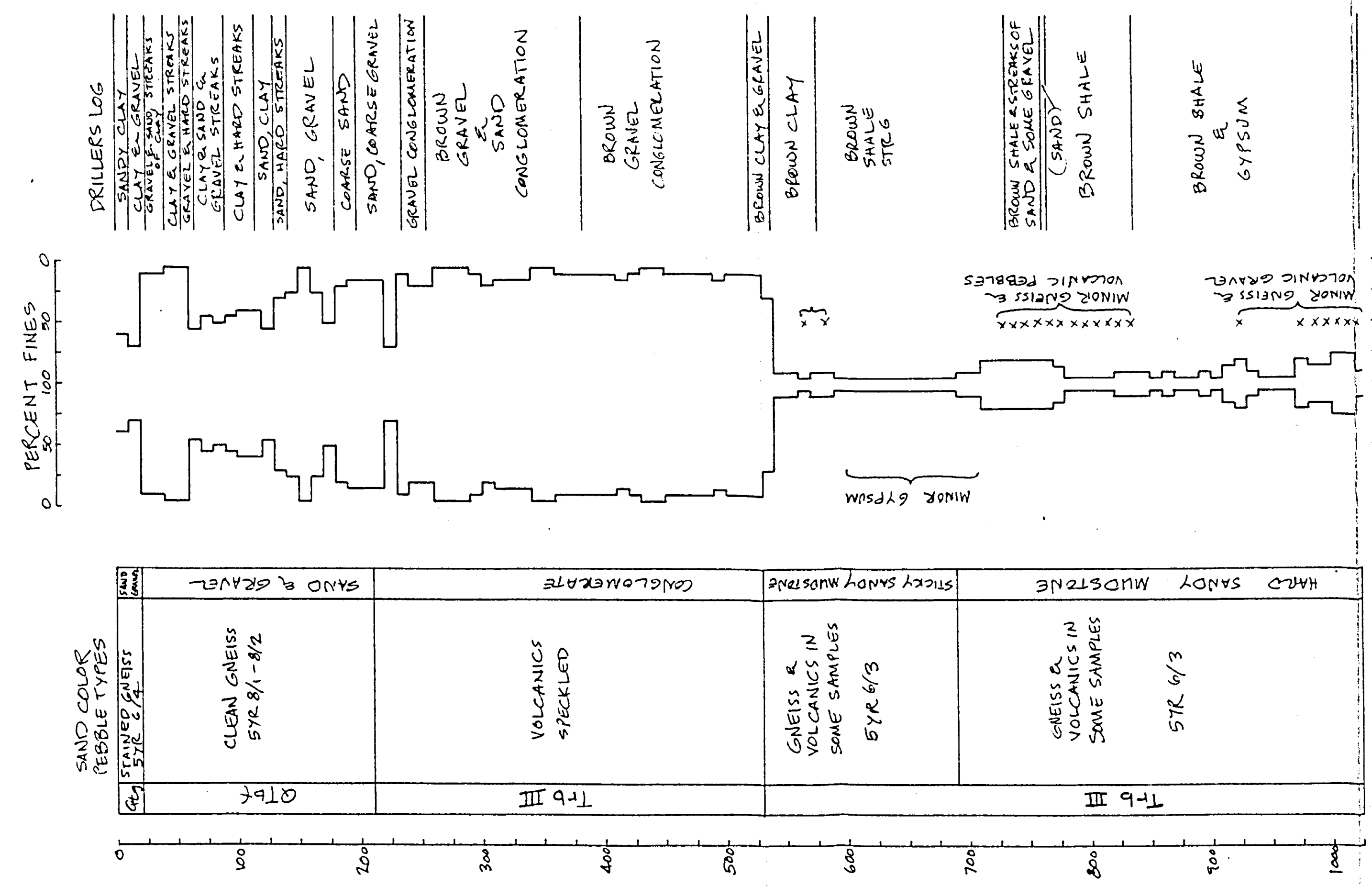

8

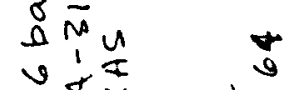

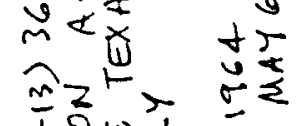
एकำ

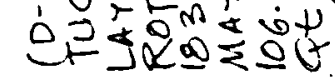

3 की

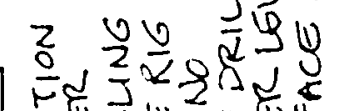
势

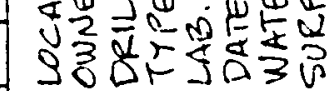

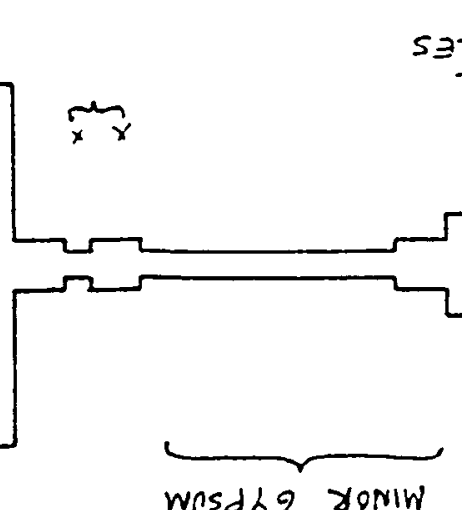

$\overbrace{x \times x \times x}$

3 sslang vioniw

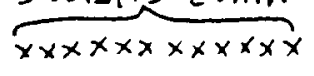
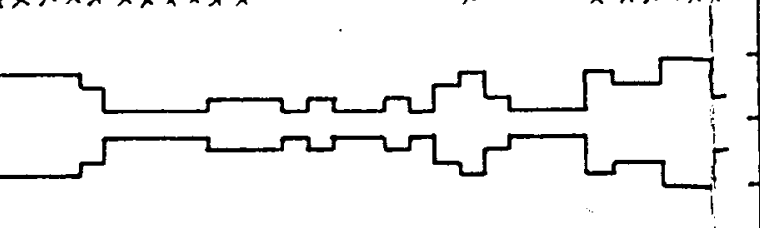

wasdhg rowiw

\begin{tabular}{|c|c|c|c|}
\hline asonw honrs hxols & $3 N 21 S C M W$ & LONYS & $\mathrm{COWHH}$ \\
\hline 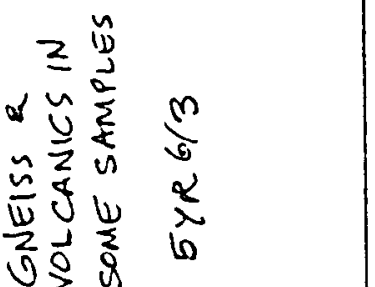 & 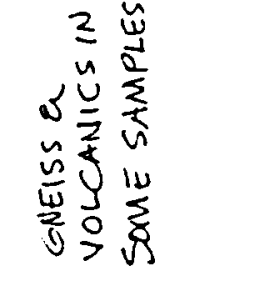 & $\begin{array}{l}\text { m } \\
\text { s } \\
\text { है } \\
\text { s. }\end{array}$ & \\
\hline \multicolumn{4}{|c|}{ III $9+1$} \\
\hline
\end{tabular}




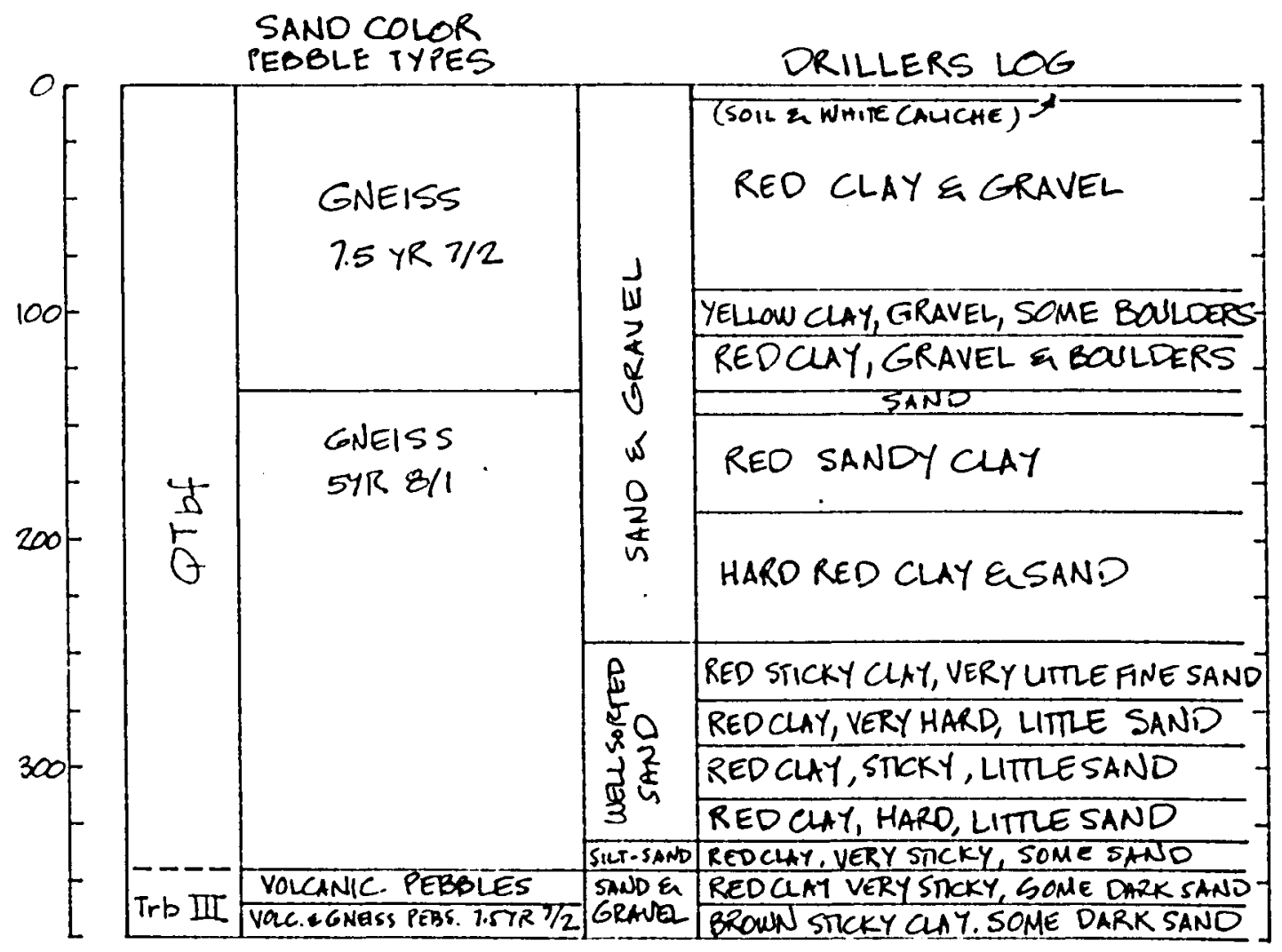

400

LOCATION

OWNER

DRILLING CO.

DRILLER

LAB.NO.

DATE DRILLEO

WATER LEVEL

SURFACE OUICROP
$(0-13-13) 36 d d c b$ CITY OF TUCSON A3 CW.PISTOR

1873

MAT 1950 103' MAY 1950 
183
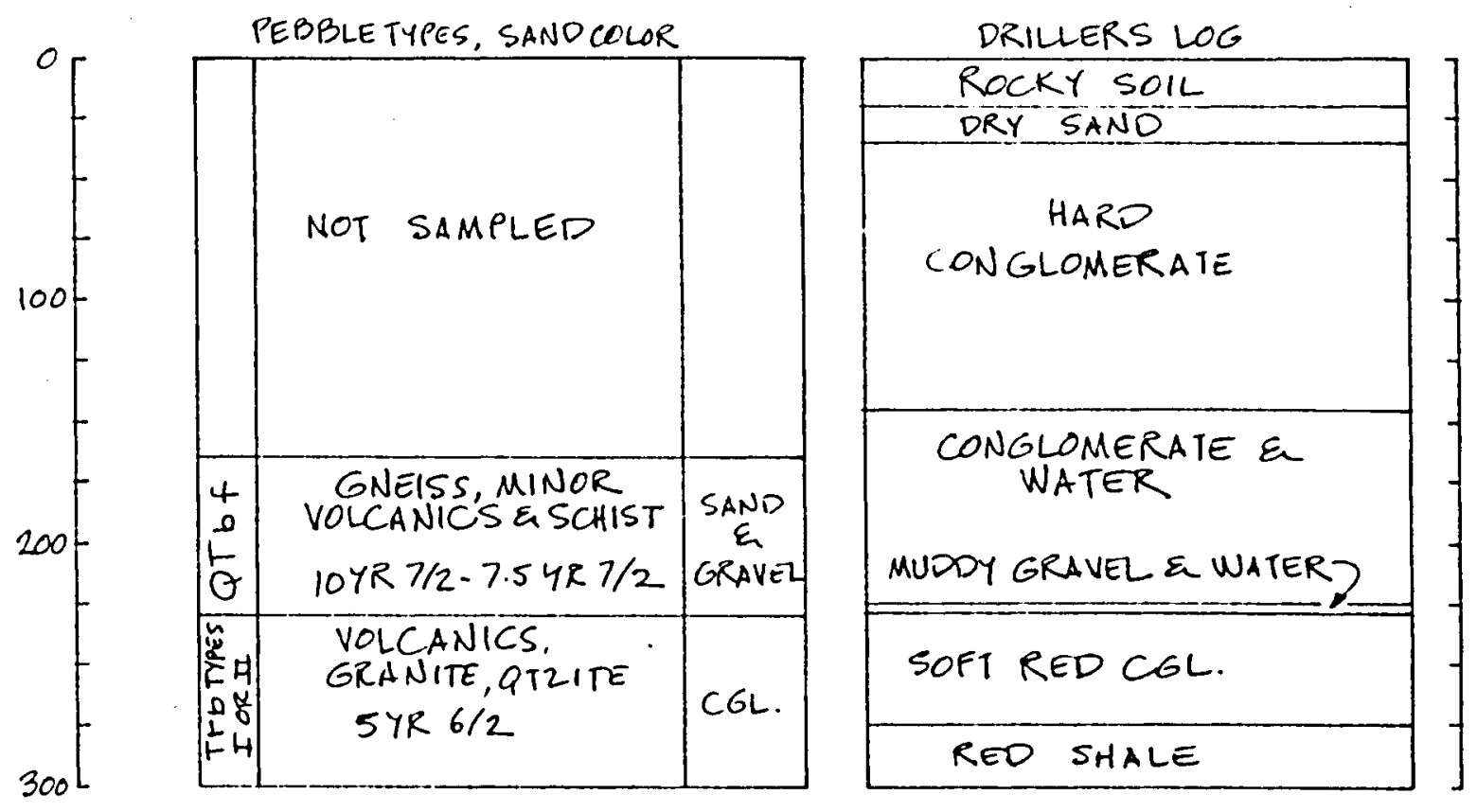

2

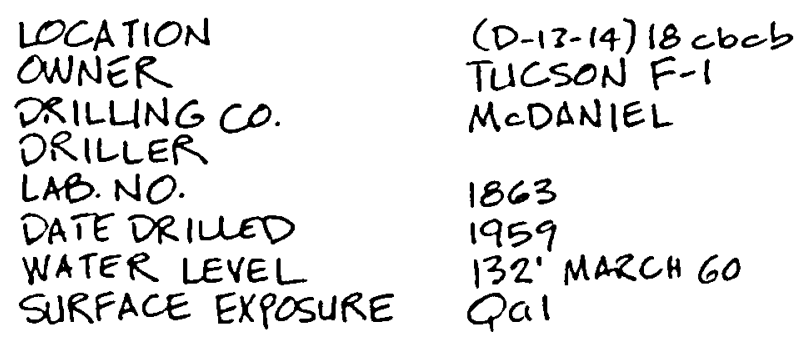




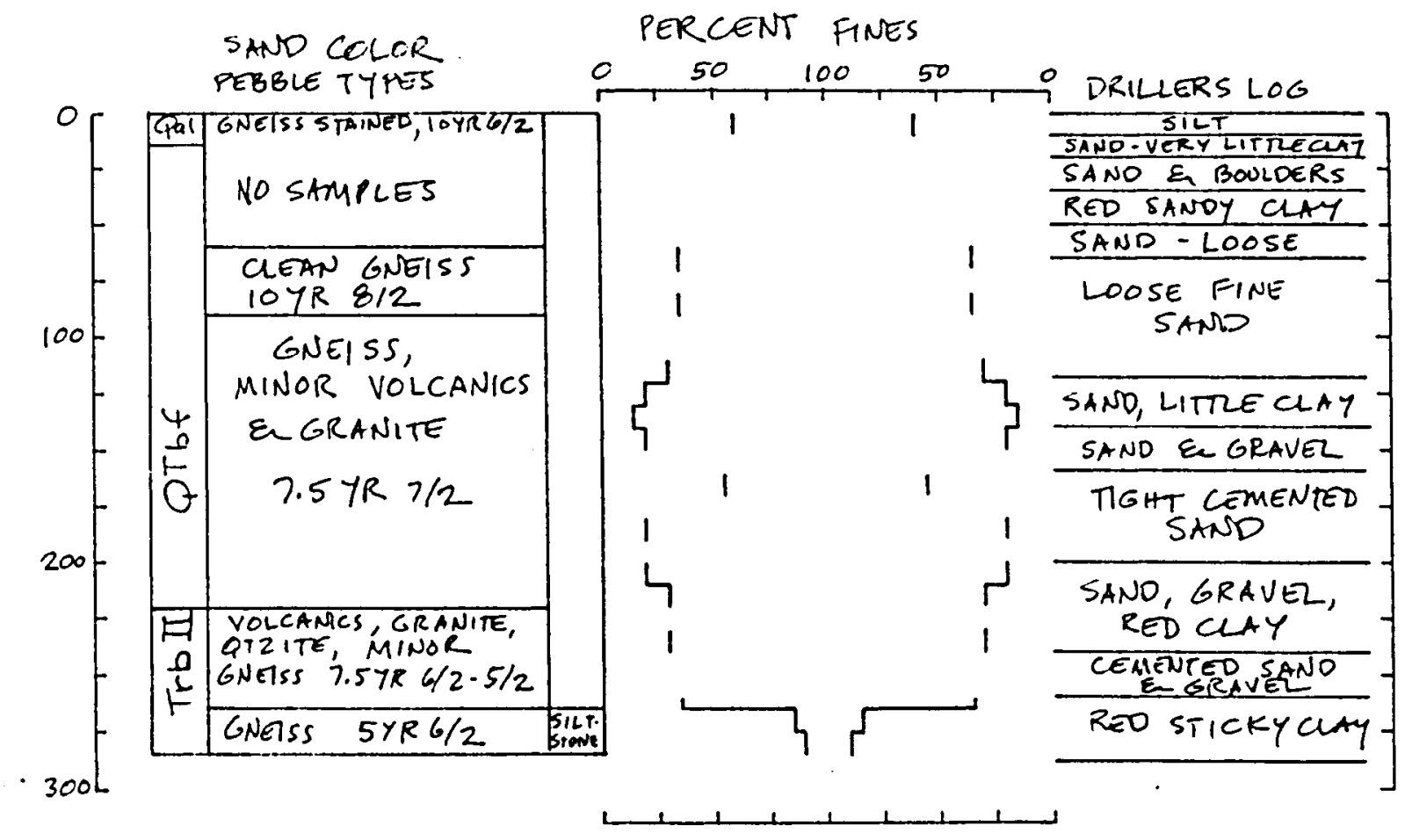

LOCATION

OWNER

DRILLING CO.

DRILLER

LAB. NO.

DATE DRILLD

WHTER LEVEL

suRface exposure
$(0.13-14) 19$ ddace UofA. FARM \#3 PISTOR

1731

NOV. 1959 $75^{\prime}$ Nov. 59 Qal 


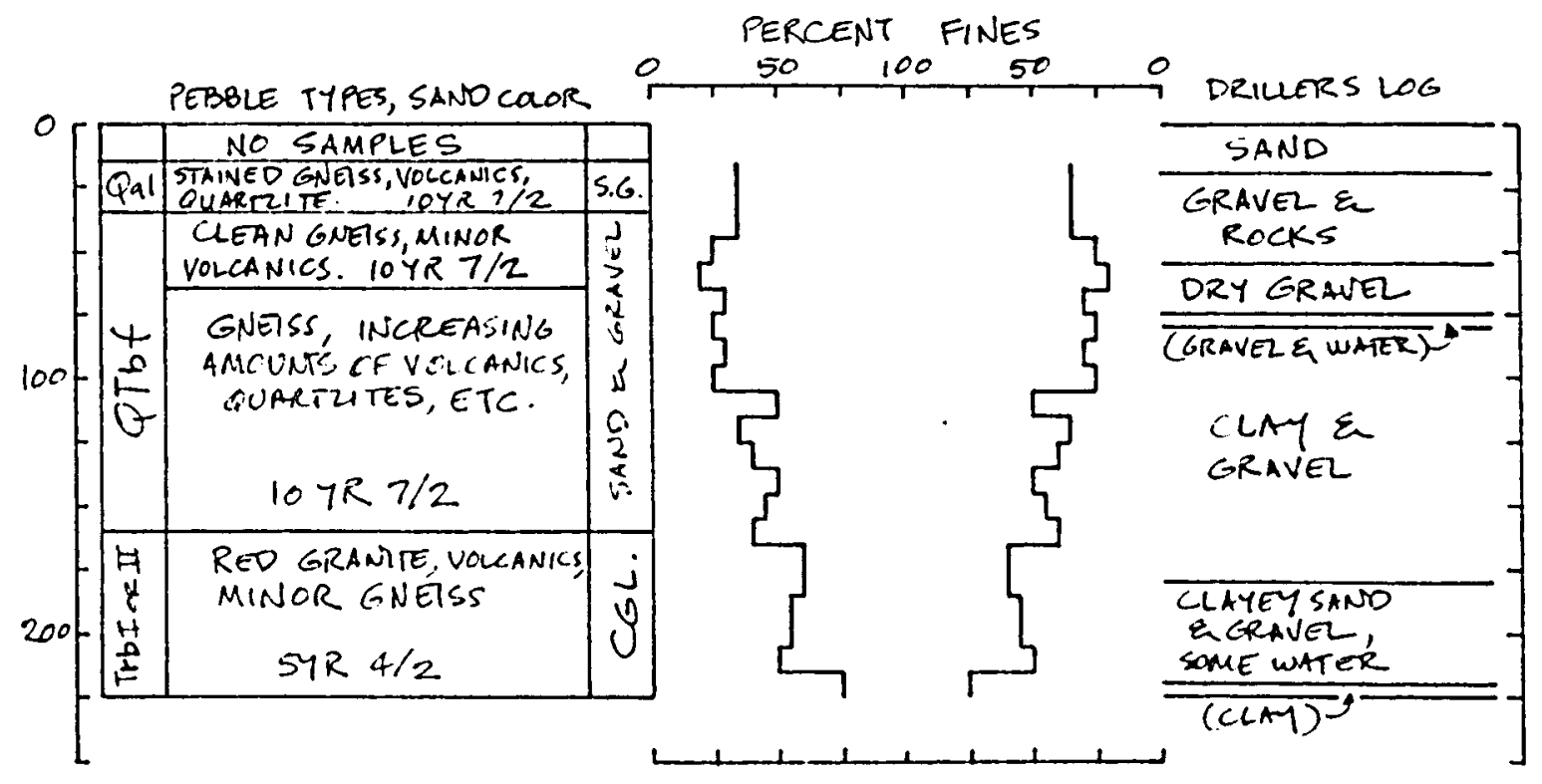

LOCATION

OWNER

$(0-13-14) 20 \mathrm{cbdc}$

DRILUNG CO.

MCRPHY

ORILLER

MEDANIEL

LAB. NO

GIBSON

DATE DRILLED

2171

NATER LEVEL

IUNE, 1965

SURFACE EXPOSURE 71' JuLY, 65 Qal 


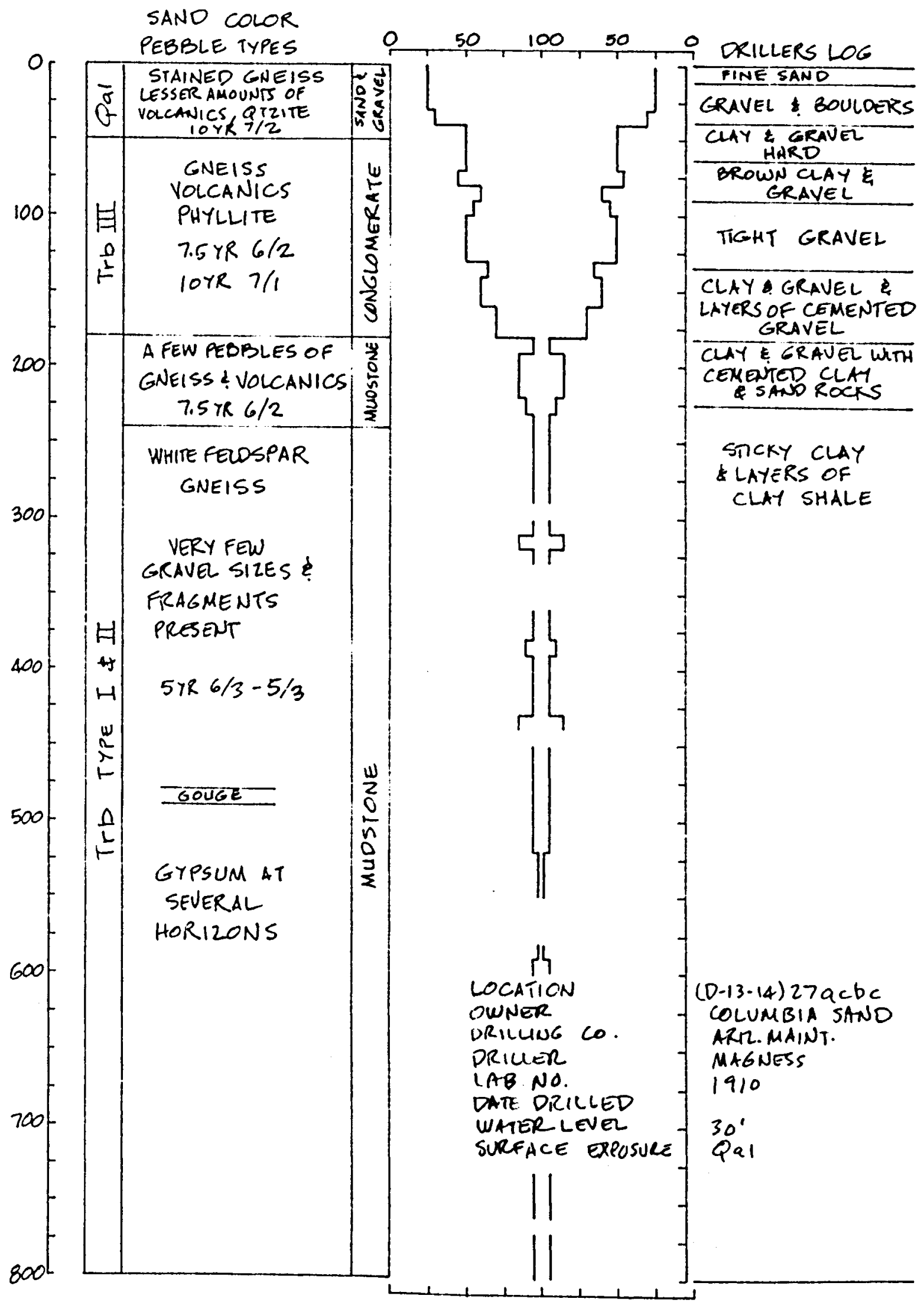




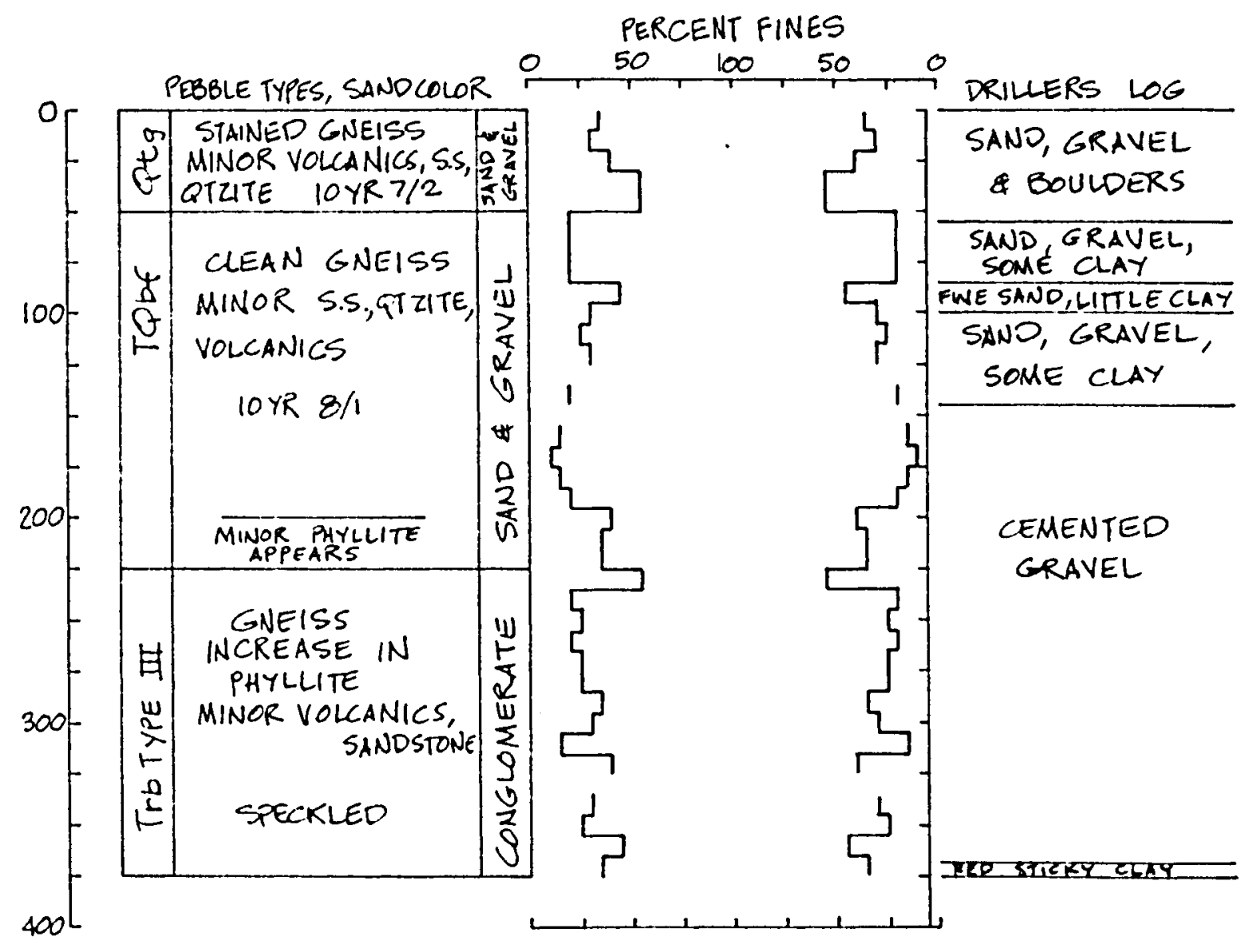

LOCATION

(D.13-14)27ccdd

OWNER BENDER

DRILUNG CO.

PISTOR

ORILLER

LAB NO.

1733

DATE DRILLED

APRIL, 1961

WATER LEVEL

SURFACE EXPOSURE 


SANO COLOR
PEBBLE TYPES

LCLATICN

OWNAER.

LPILLINGCO.

DFILLER

LAB.NO

Date brilleD

WATER LEVEL

EURFACE OUITAOO
$(0-13-14) 28 \mathrm{ada}$

UNIV Cf ARIZCNA

CW. ASTOR.

1380

NON.1761

$57^{\prime} \mathrm{NON} 1961$ 


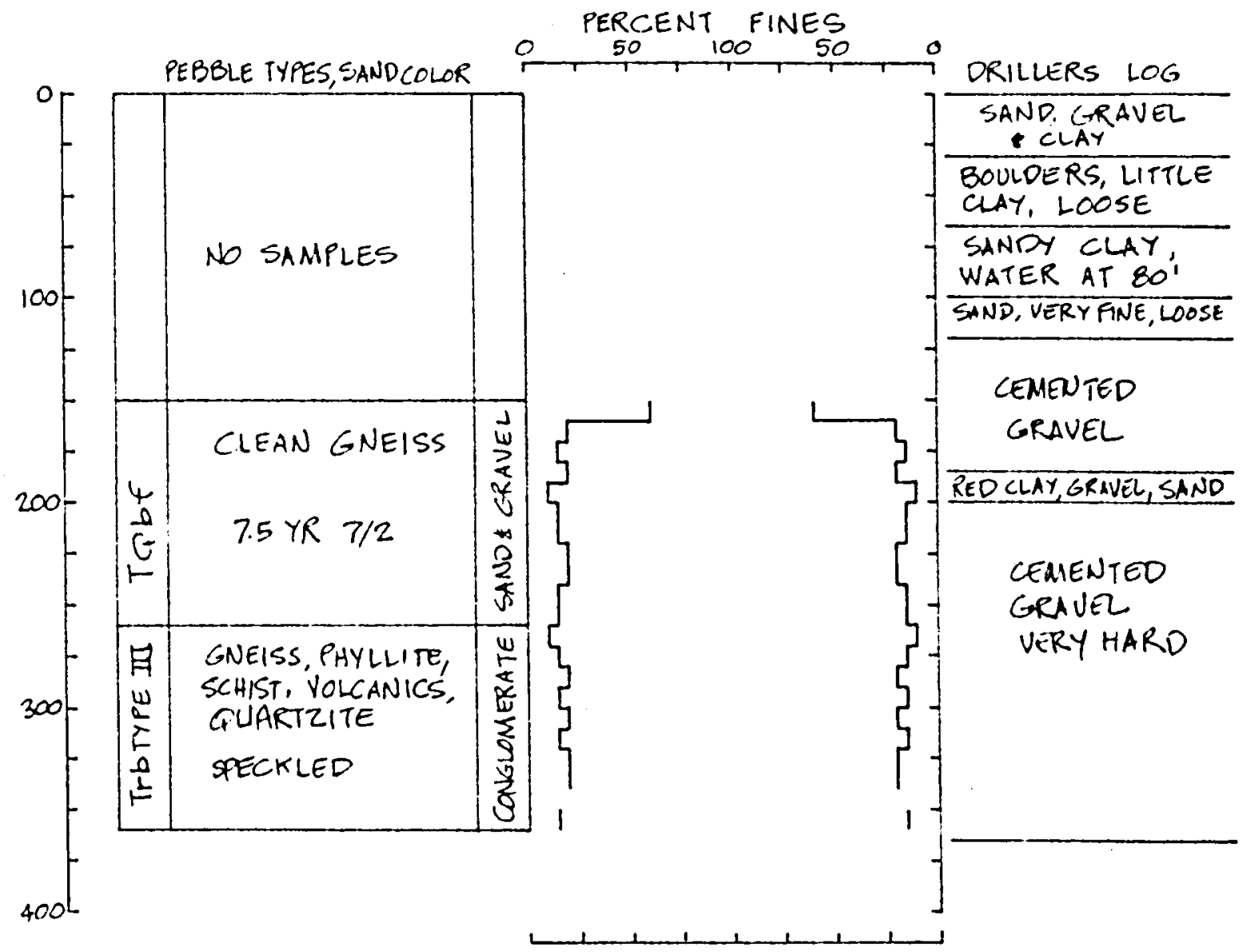

LOCATION

CWNER

DRILLINGCO.

DRILLER

LAB. NO.

DATE DRILLED

WATER LEVEL

SURFACE EXPOSURE
$(0,13-14) 28$ ddbc BENDER PISTOR THOMPSON 1750 $79^{\prime}$ oct 63 


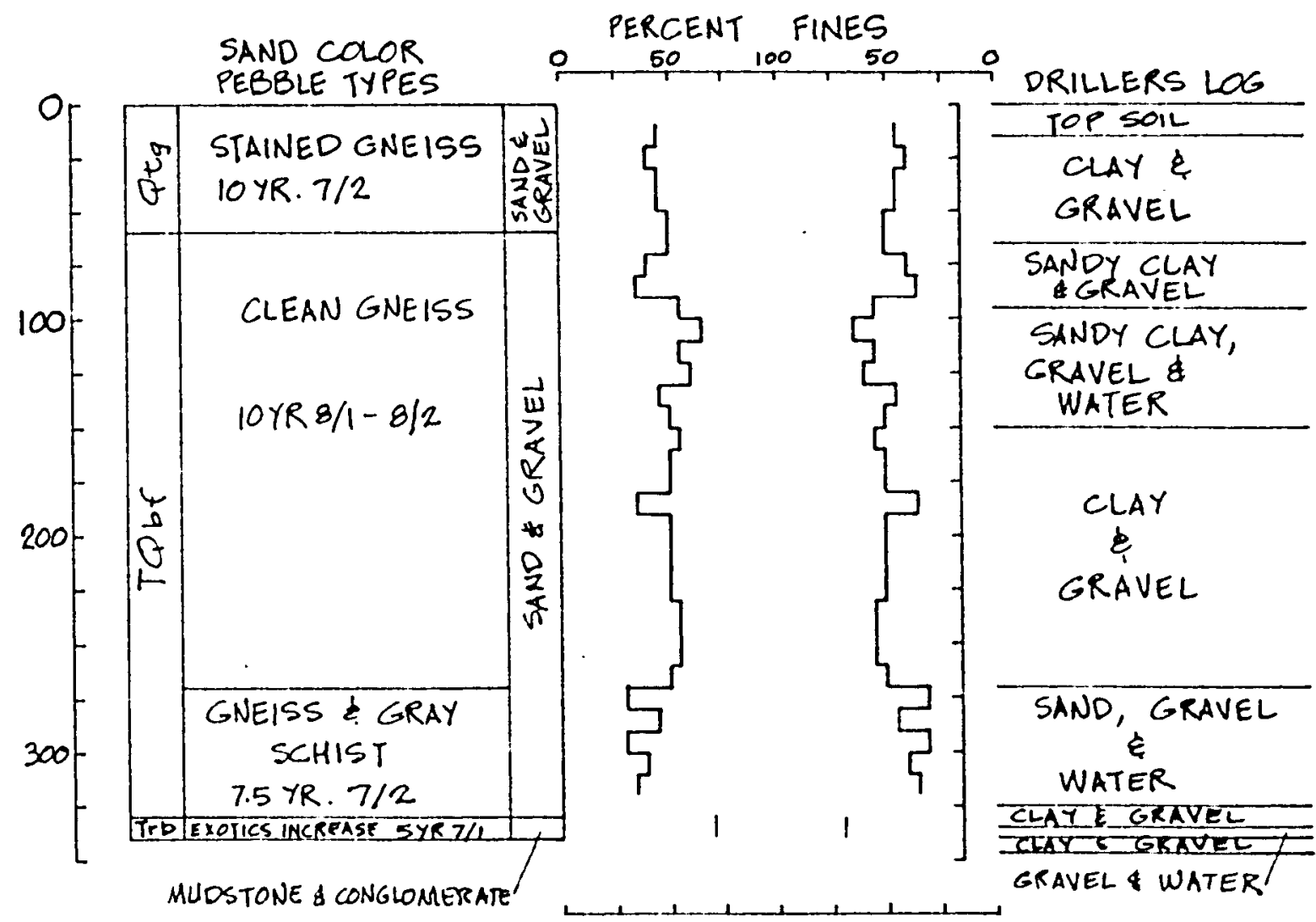

LOCATION

OWNER

DRILLING CO.

DRILLER

LAB. NO.

DATE DRILLED

WATER LEVEL

SLRFACE EXPOSURE
$(0-13-14) 29$ dc ba WINTERHAVEN COOP MCDANIEL GIBSON

1836

MAY, 1964 85' MAY 64 Qtg 
191
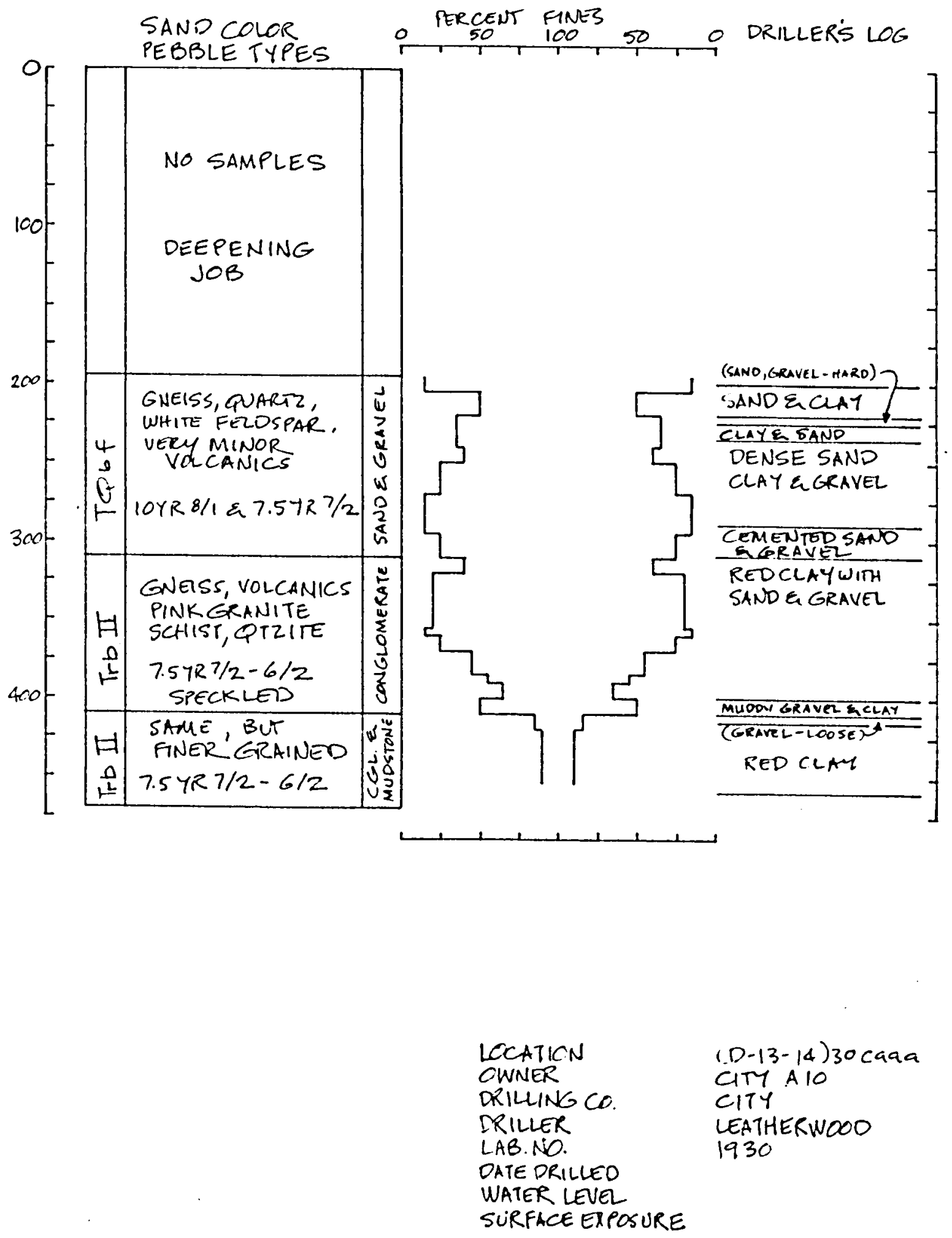

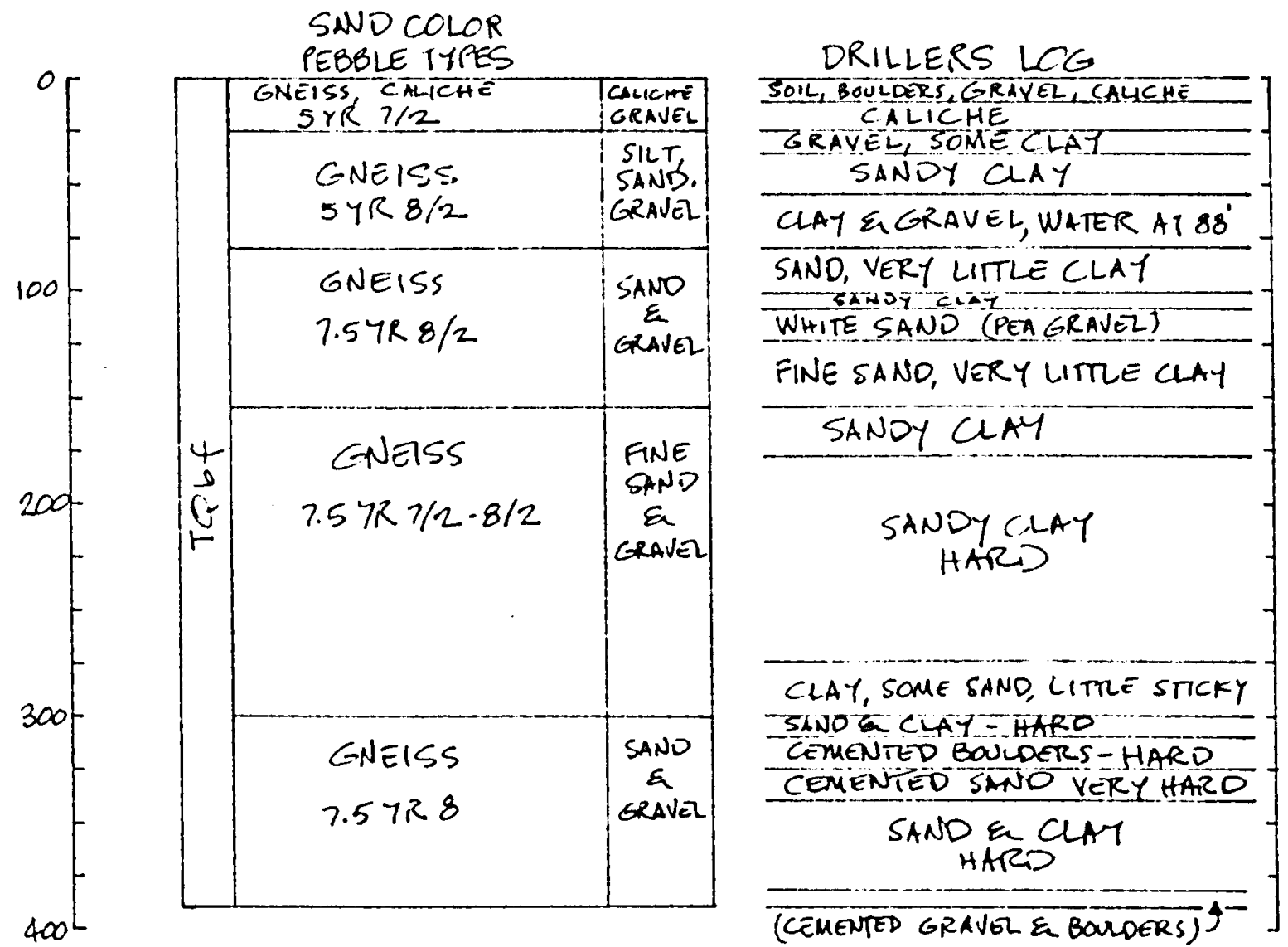

LOCATION

OWNER

DRILLING CO.

DRILLER

LAB.NO.

DATE ORILED

WATER LEVEL

SURFACE EXPOSURE

$(D+3-14) 31$ dbaa

TUCSON B-10

PISTOR

THCMPSON

1872

APRIL, 1950

QbF APRIL,50 


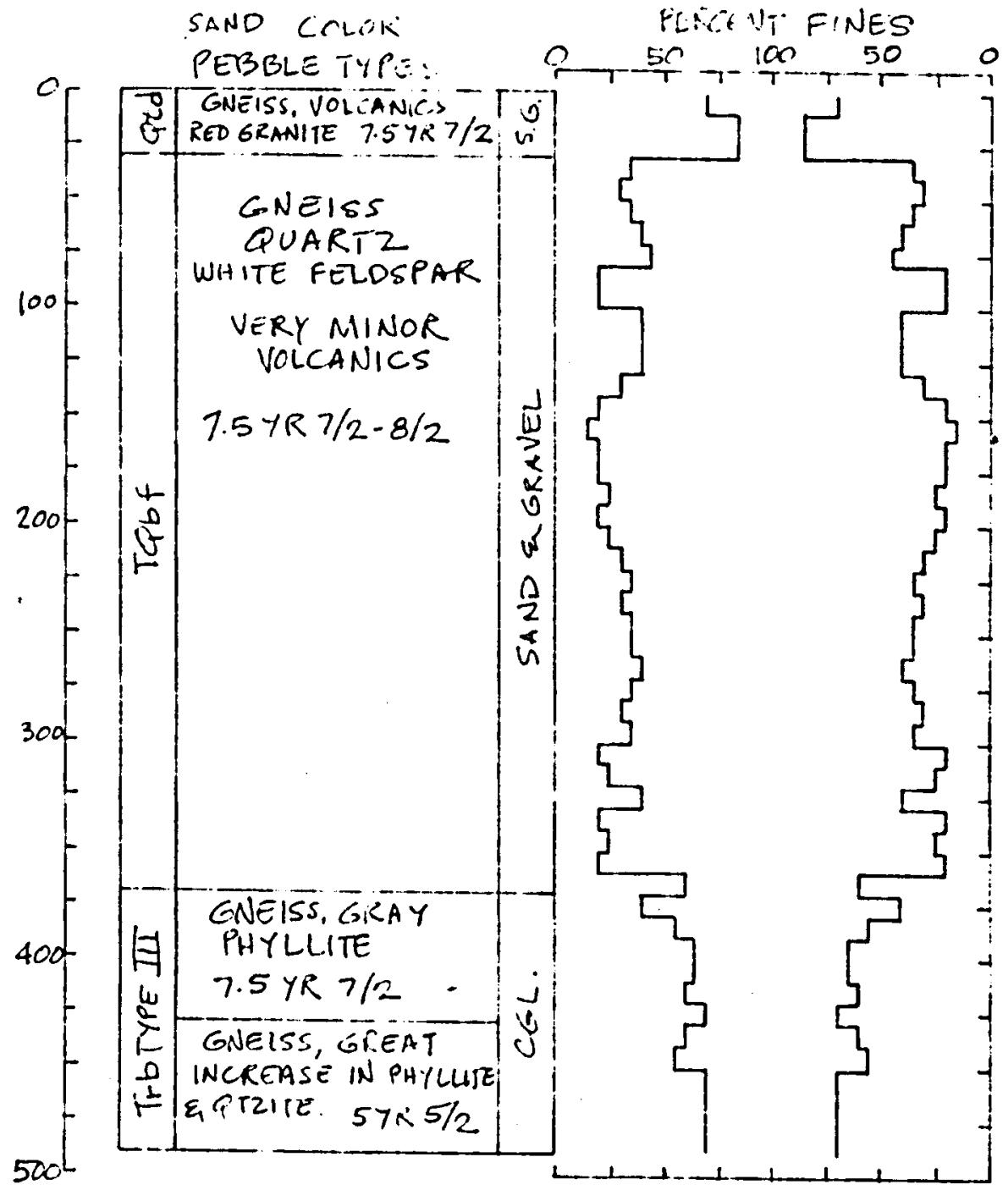

LCCATICN

OWNER

DRIILLING CO.

DRILLER

LAB.NO.

DATE DRILLEO

WATER LEVEL

SURFACE EXPOSURE

$(D-13-14) 32$ aade

TUCSCN 8.75

MCDANIEL

HEALDT

1916

oct. 1964

$103^{\circ}$

cetg 


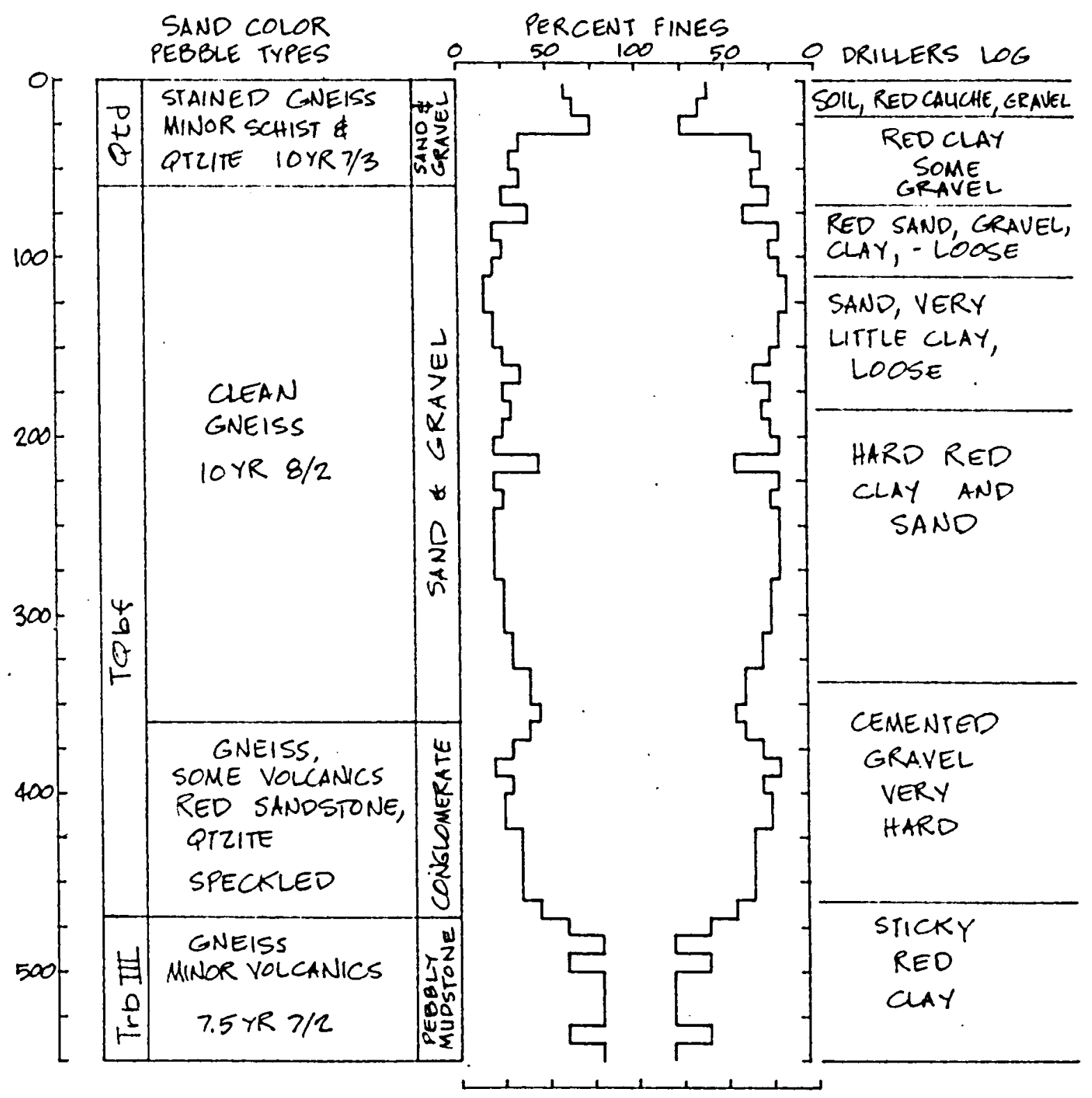

$\begin{array}{ll}\text { LOCATION } & (0-13-14) 32 \text { bad } \\ \text { OWNER } & \text { TUCSON A-27 } \\ \text { DRILUNG CO. } & \text { PISTOR } \\ \text { ORILLER } & \\ \text { LAB.NO. } & 1738 \\ \text { DATE DRILLED } & \text { OCT,1964 } \\ \text { WATER LEVEL } & 94 ', \text { OCT.64 } \\ \text { SURFACE EXPOSURE QT9 }\end{array}$




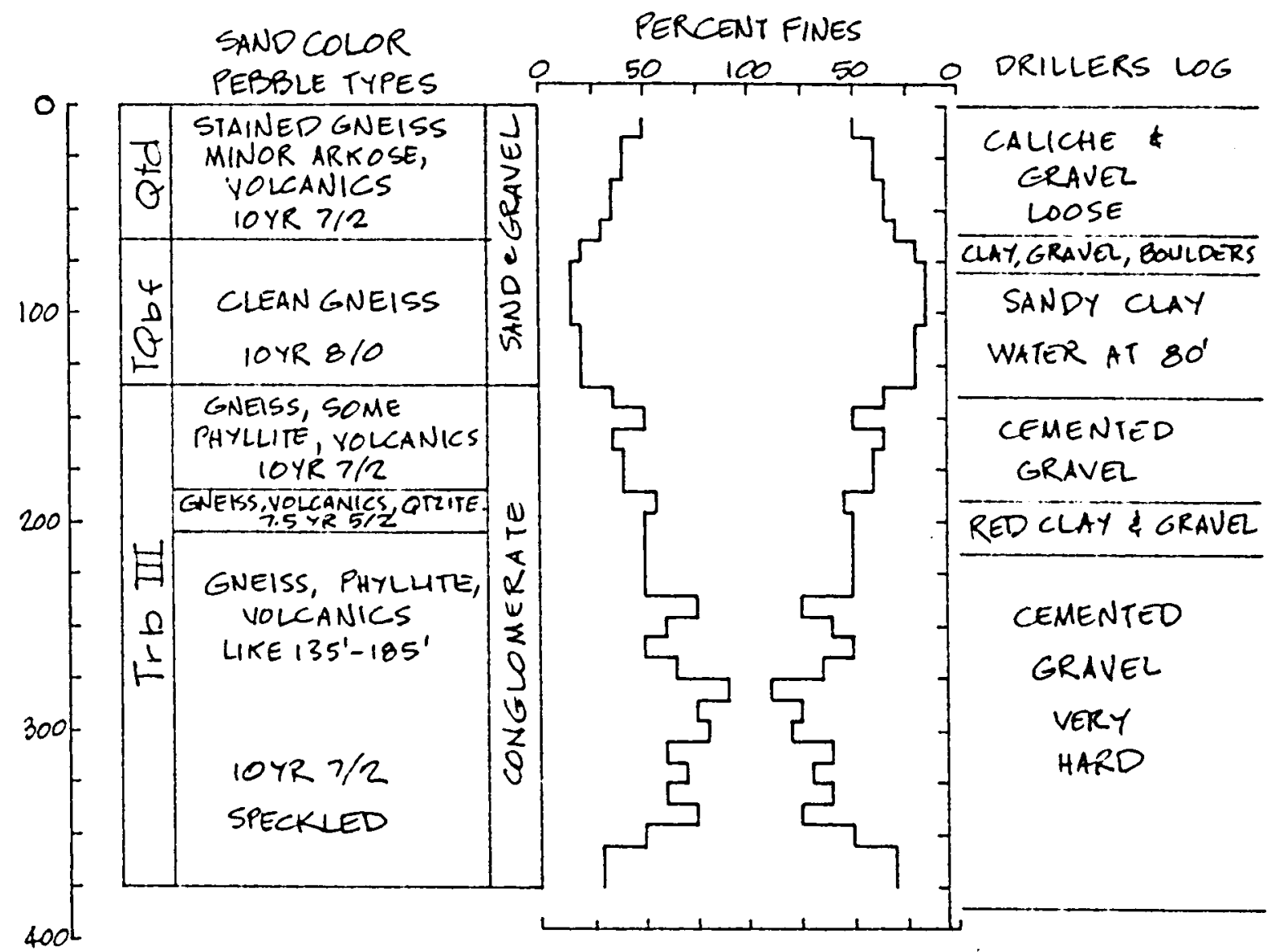

LOCATION

OWNER

Priulnsco.

DRILLER

LAB. NO

DATE ORILLED water lever

SURFACE ERPOSURE
(D-13-14) 34 andb

bender PISTOR THOMPSON

1758

DEC, 1963

$80^{\prime}$ DEC 63

Qal 


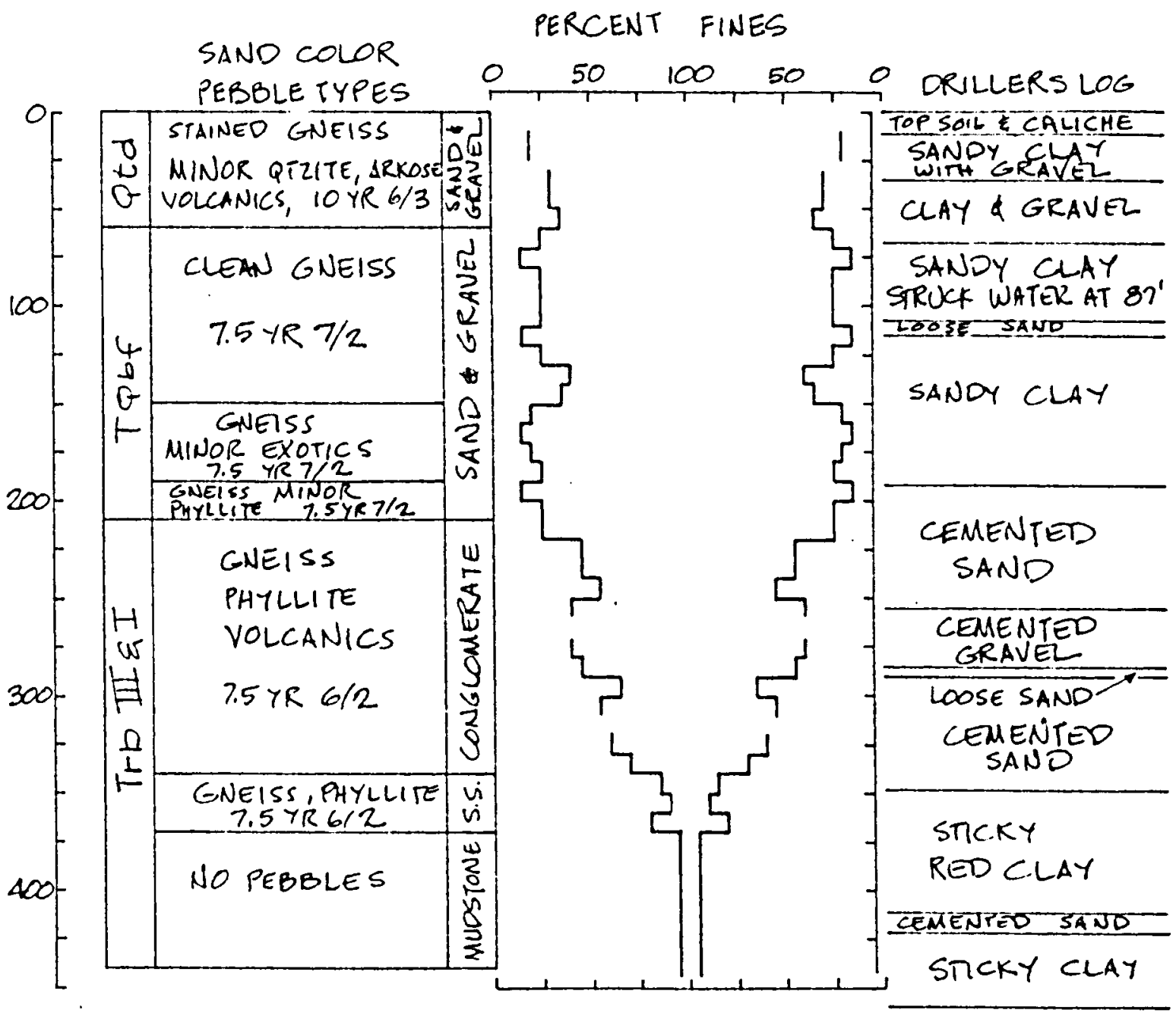

LOCATION (D-13-14)34abbd

OWNER TUCSON B-73

DRILLING CO. PISTOR

DRILLER GASTELUM

LAB NO. 1803

DATEDRILUED MARCH 1964

water lever 81' March 64

SURFACE ERPOSURE Qtg 
197

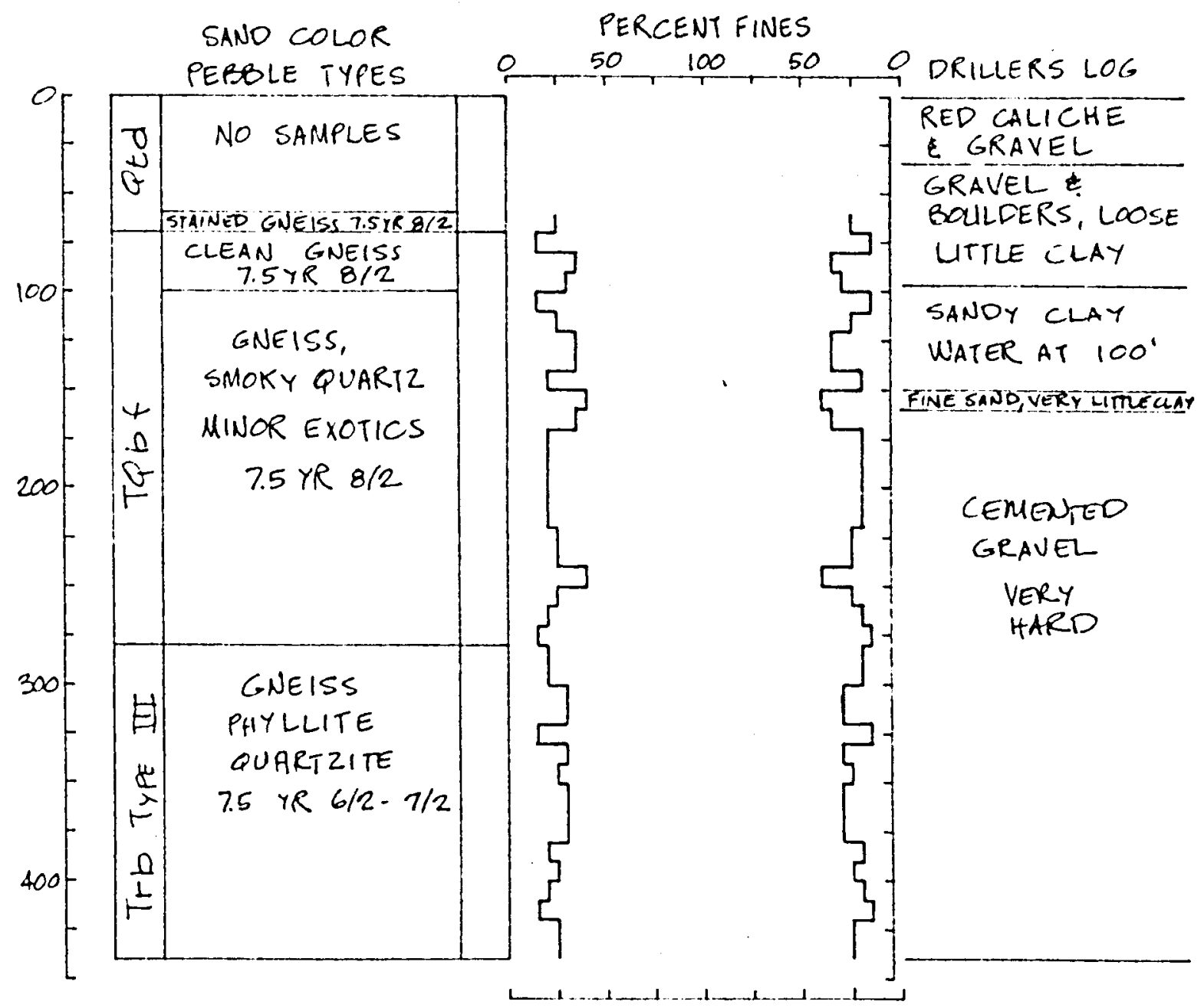

$\begin{array}{ll}\text { LOCATION } & (D-13-14) 34 \text { aCbC } \\ \text { OWNER } & \text { BENDER-TULSON } \\ \text { DRILLINGCO. } & \text { PISTOR } \\ \text { DRILLER } & \\ \text { LAB.NO. } & 1734 \\ \text { DATEDRILLED } & \text { JUNE,196! } \\ \text { WATER LEVE } & 90^{\prime} \text { JUNE'6I } \\ \text { SURFACE EROSURE } & \end{array}$




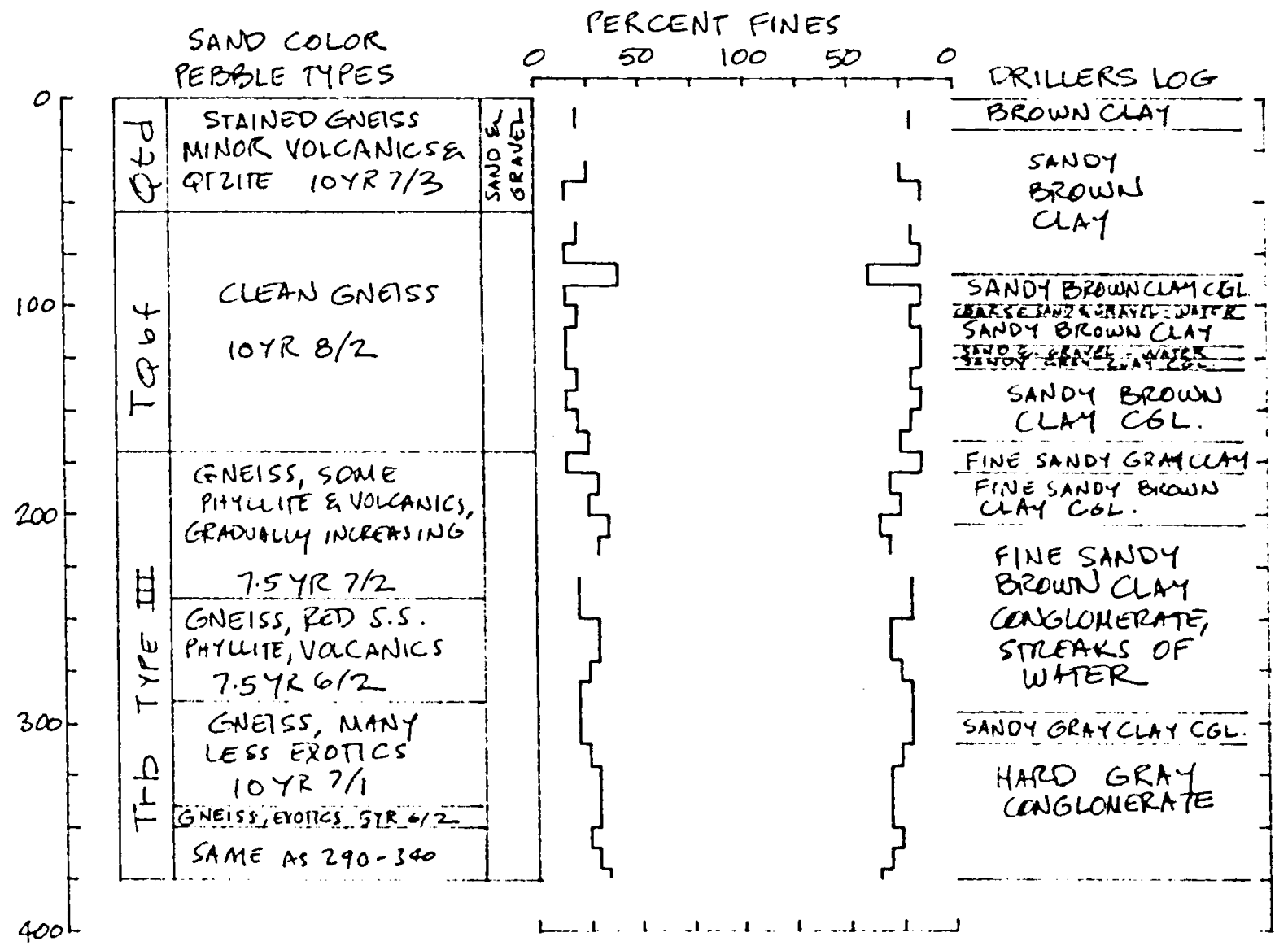

LOCATIEN

OWNER

DRIUINGCO.

DRILLER

LAB. NO.

DATE DRILLED

WATER LEVEL

SURFACE EXPCSURE
$(0-13-14) 35$ adde

TUCSCN B-27

FORSYTH

BANGHART

1736

IUNE, 1962

$83^{\circ}$

QES 

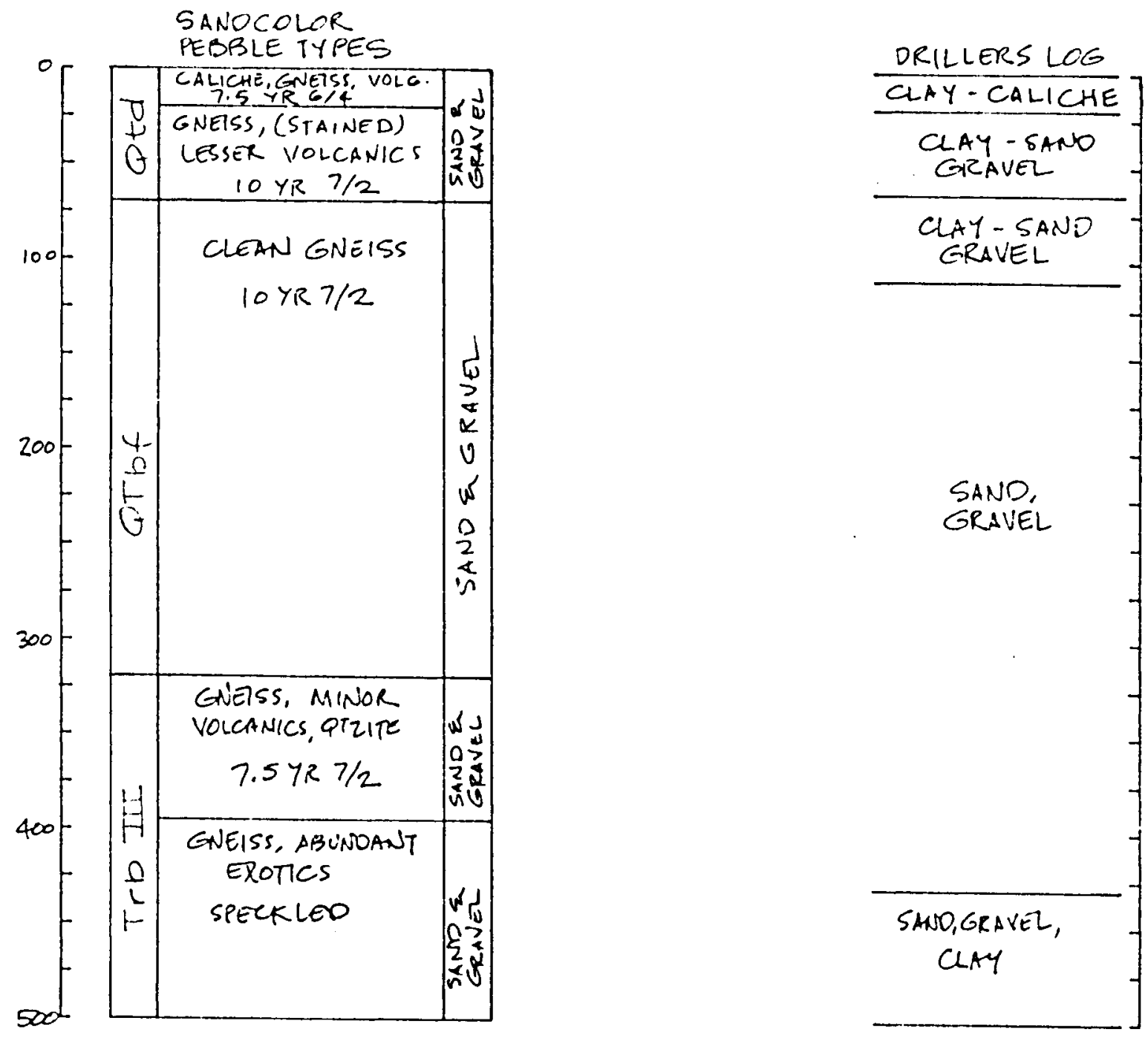

LOCATION

Quilar

ORILLINGCO.

DRILER

LAB.NO.

DATÉ DRILLED

WATER LEV

SURFACE EXPOSURE
$(0-13-14) 35$ ccaa TUCSON B7T

BORING

DIAZ

1987

MARCH, 1965 


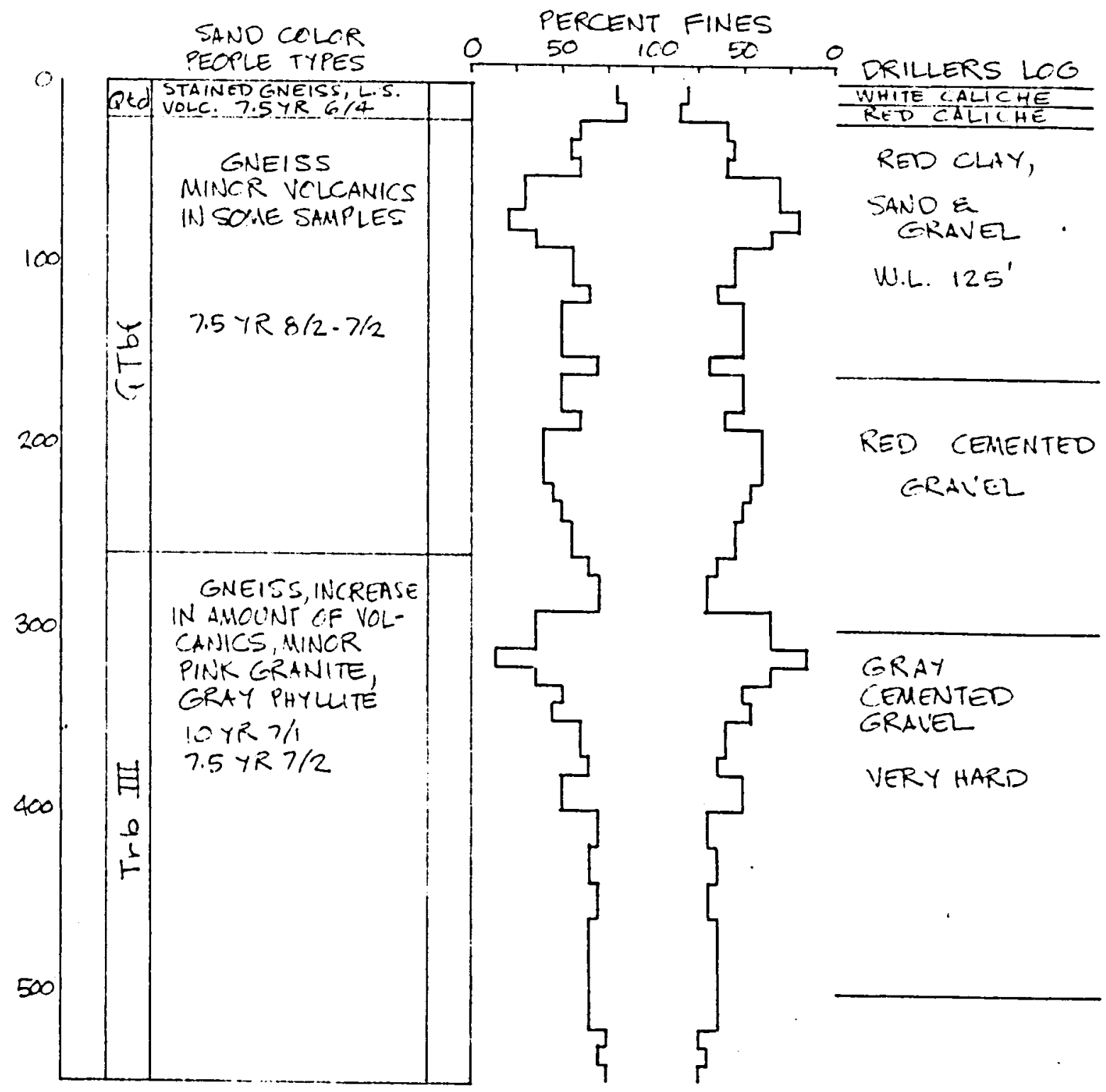

LOCATICN

CWNER

DRILLING CO.

ORILLER

LAB. NO.

DATE DRILLO

WATER LEVEL

DLRFACE EXYOSURE

(D-13-14) 36 cdaa GKANTWCOD CEM. PISTCR

THCMPSON

1919

NOV: 64

$125^{\prime}$ NCV. 64 


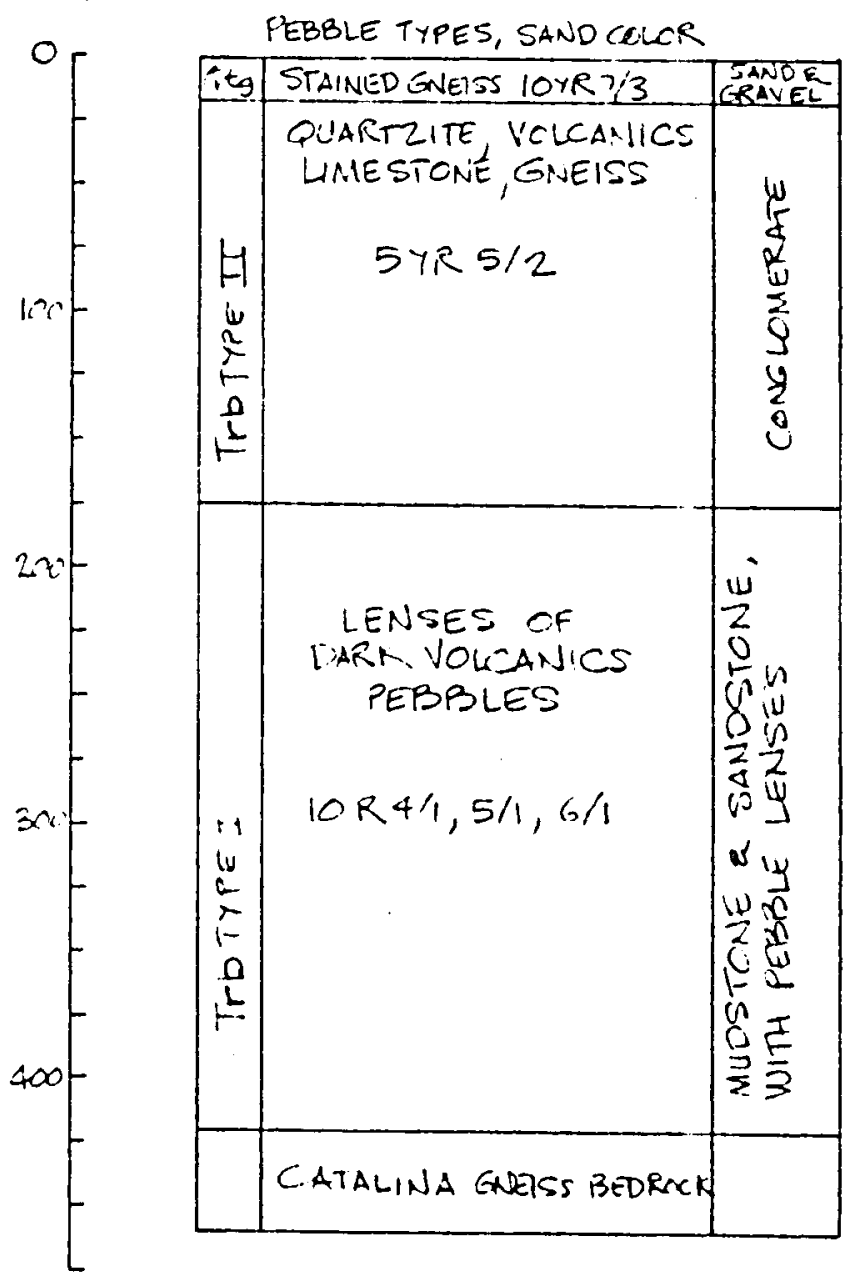

TRILLERS LOE

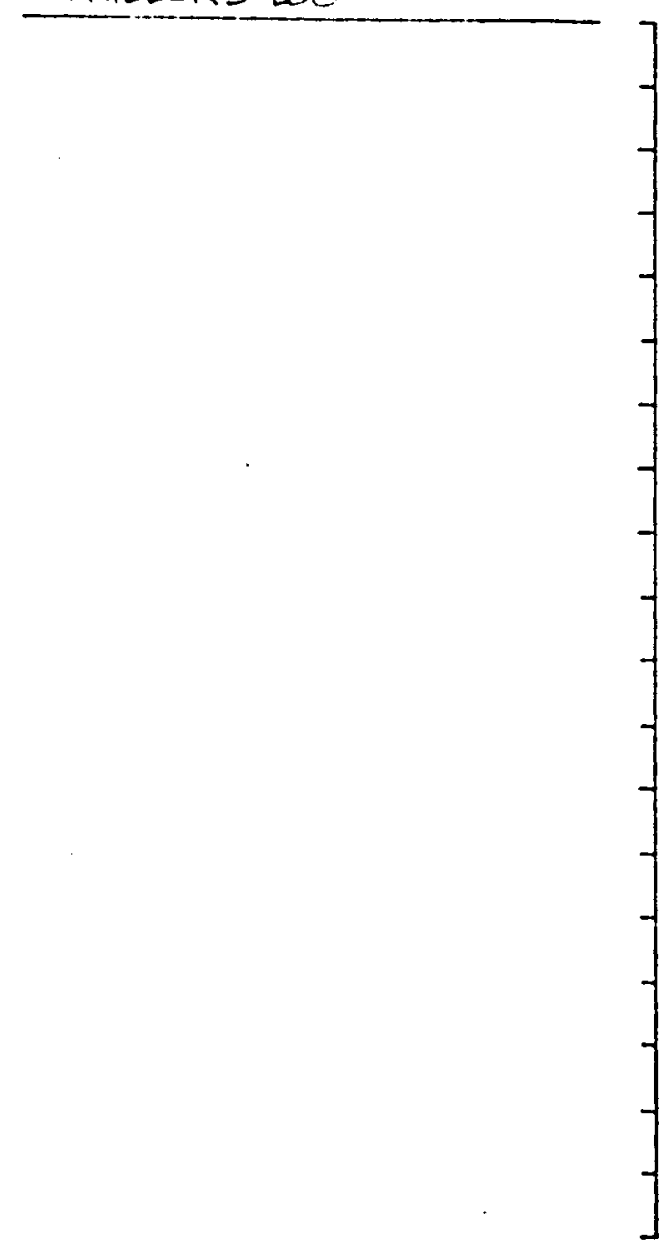

LOCATION

CWNER

ORIULINGCO.

DRILLER

LSO.NO.

DATE DRILLED

WATER LEVEL

SURFACE ERPCSURE

$(0-13-15) 6$ ccara DUNHAM

AL.BCKING CAAZ

1387

MARCH 1960

IOG' MARCH 1960

Qtg 
202

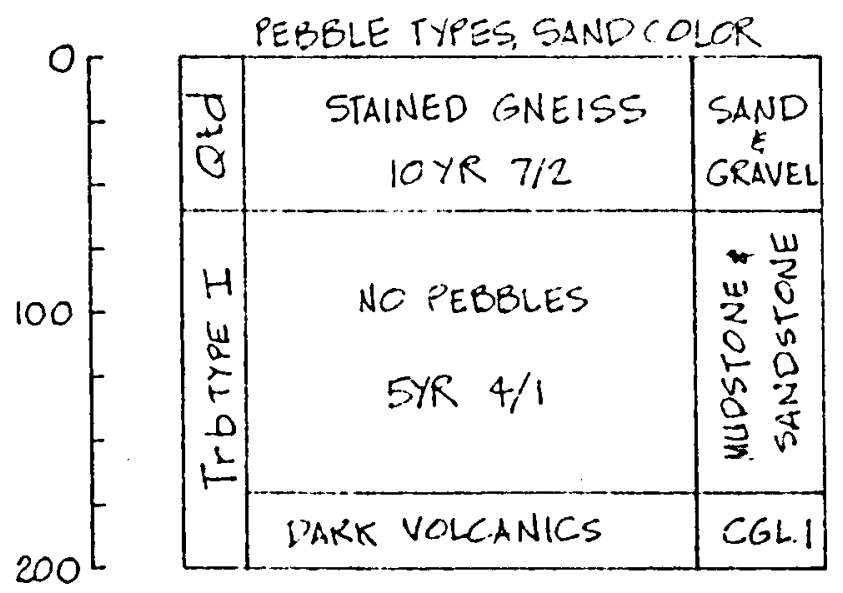

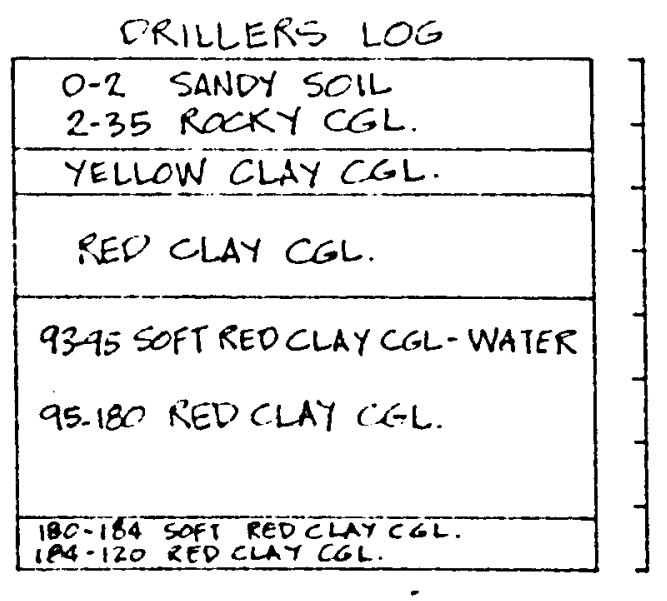

$\begin{array}{ll}\text { LOCATION } & \text { (D-13-15)8 add } \\ \text { OWNER } & \text { BOB BERRY } \\ \text { DRILLING CO. } & \text { FORSYTH } \\ \text { DRILLER } & \text { LEMONS } \\ \text { LAB. NO. } & 1861 \\ \text { TATE DRILLED } & \text { NOV. } 1960 \\ \text { WATER LEVEL } & 62^{\prime} \text { NOV, } 1960 \\ \text { SURFACE EXPOSURE } & \text { GIg. }\end{array}$



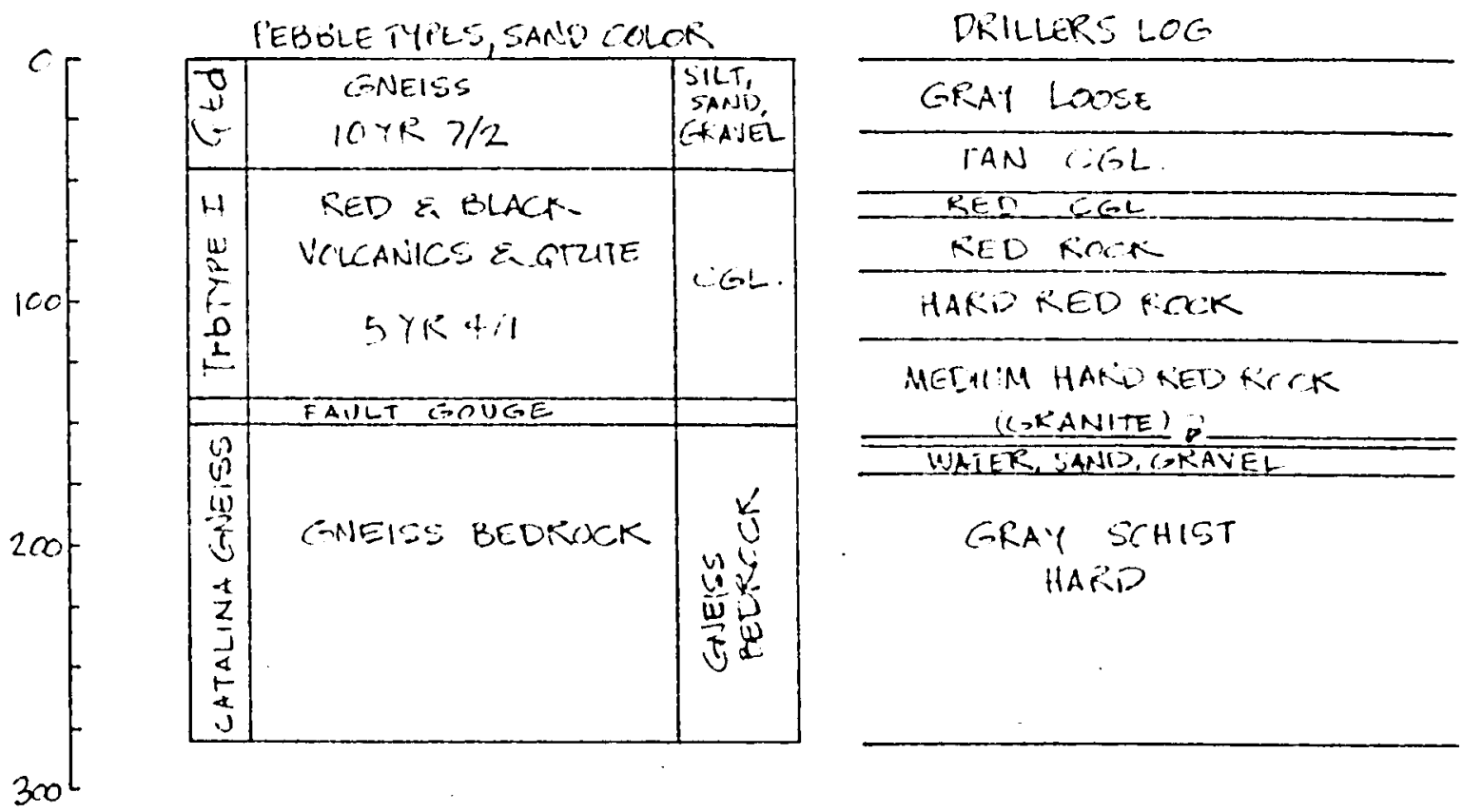

LOCATION

OWNER

ORILLING CO.

DRILER

LAB.NO.

DATE RRILLED

WATER LEVEL

SURFACE EXPSURE
(D-13-15) 9 bcc FOREST SERUKEE DUNGAN:

IUIGAN

134.5

MAFSEH, IT62

34

etg 


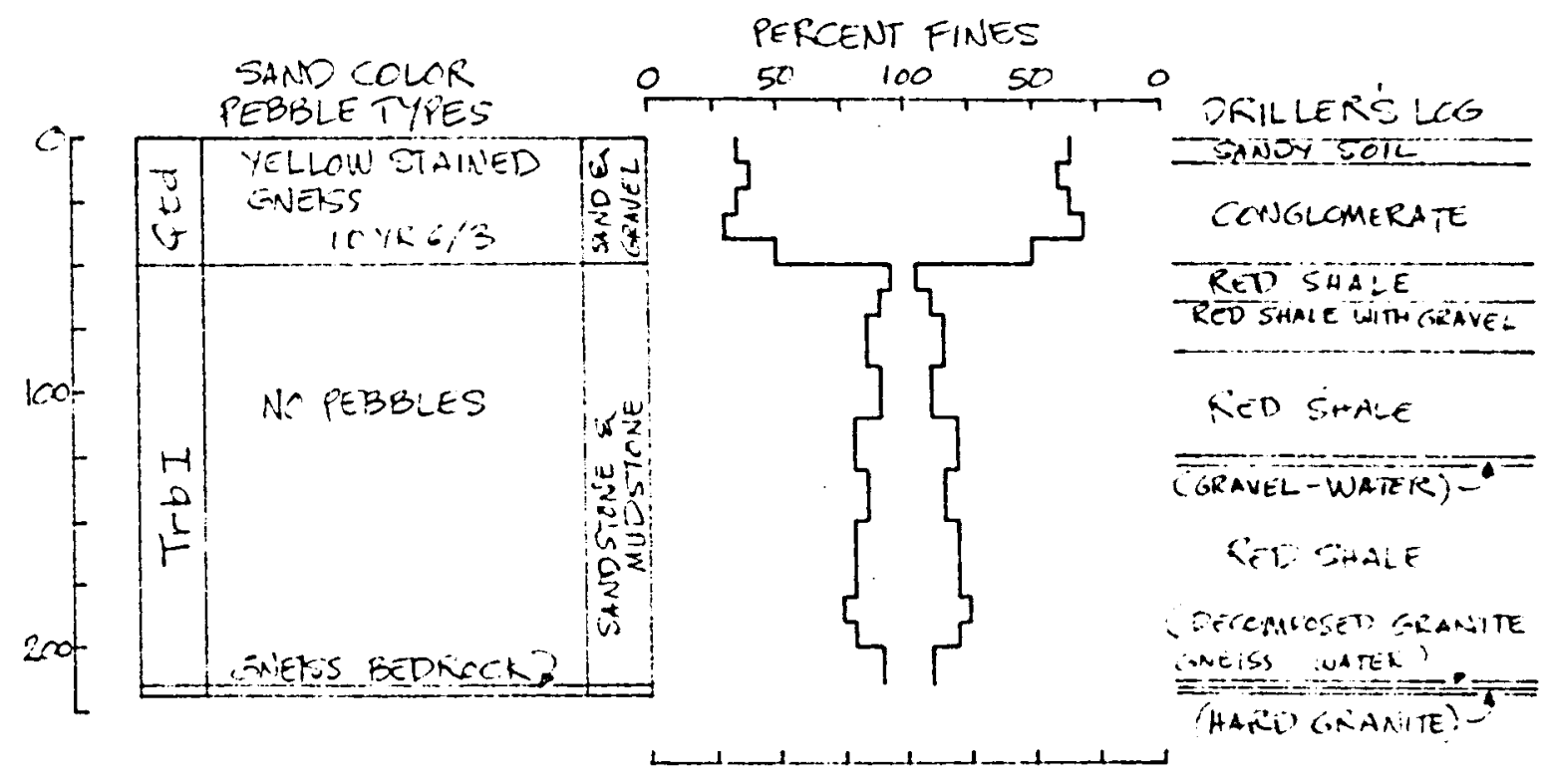

Lechteris

AINER

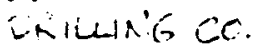

IRULER

坛 ir

GATF PIILLED

WATER LEVEL

SIKFACE ERPCITE CLA $(b-i 3-5): 3+10 a$

NRIGHT

ML DANEL

Gloscij

2af

Nîn: iq65

$1,5,40^{\circ}$ 

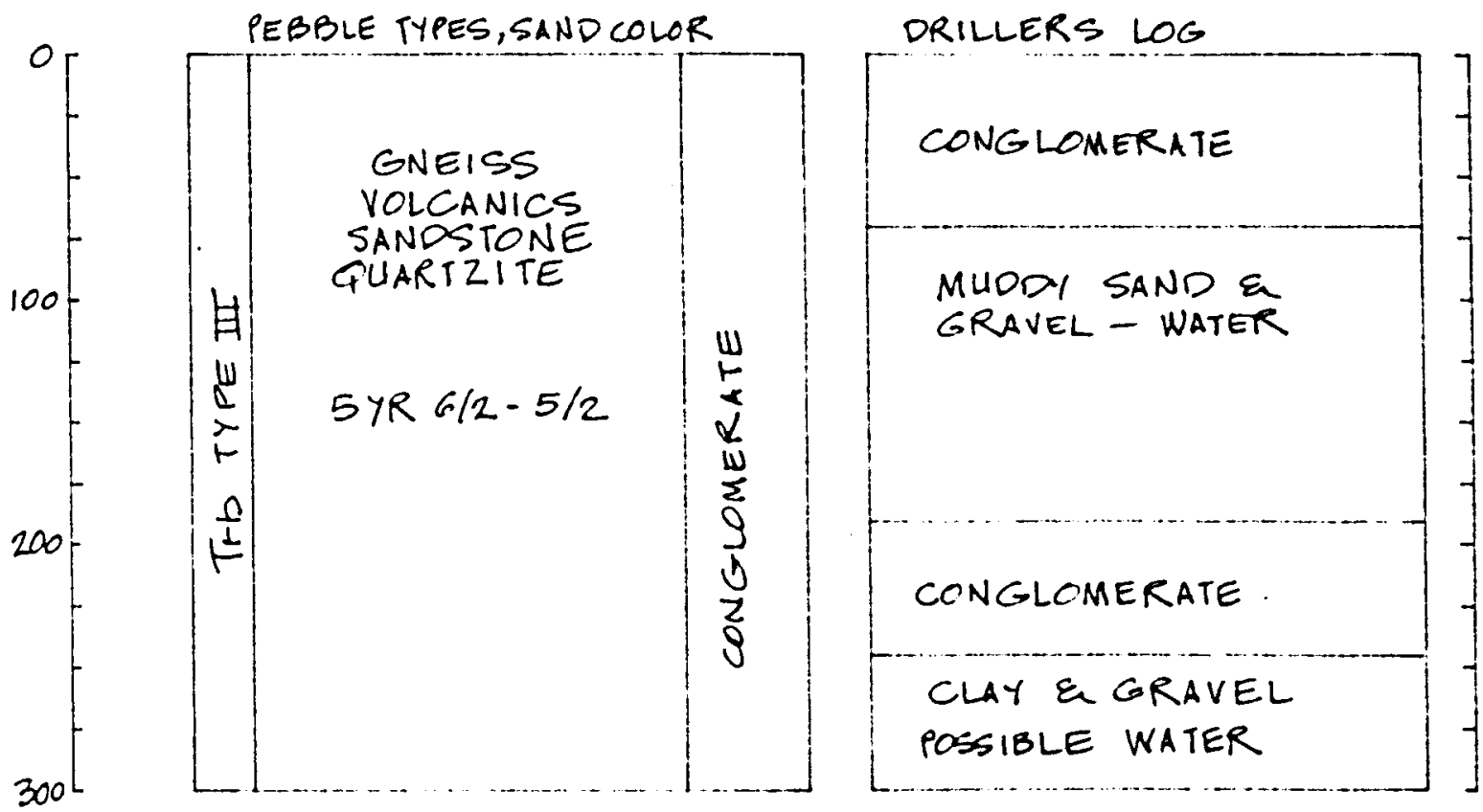

LOCATION OWNER

DRILLING CO.

DRILLER

LAB.NO.

DATE ORILLED

WATER LEVEL

SURFACE EXPOSURE
$(0-13-15) 17 \mathrm{dcc}$

KATTERLY

MCDANIEL

1381

APRIL, 1962

70' APRIL'62

TOS, TTPE III 
206

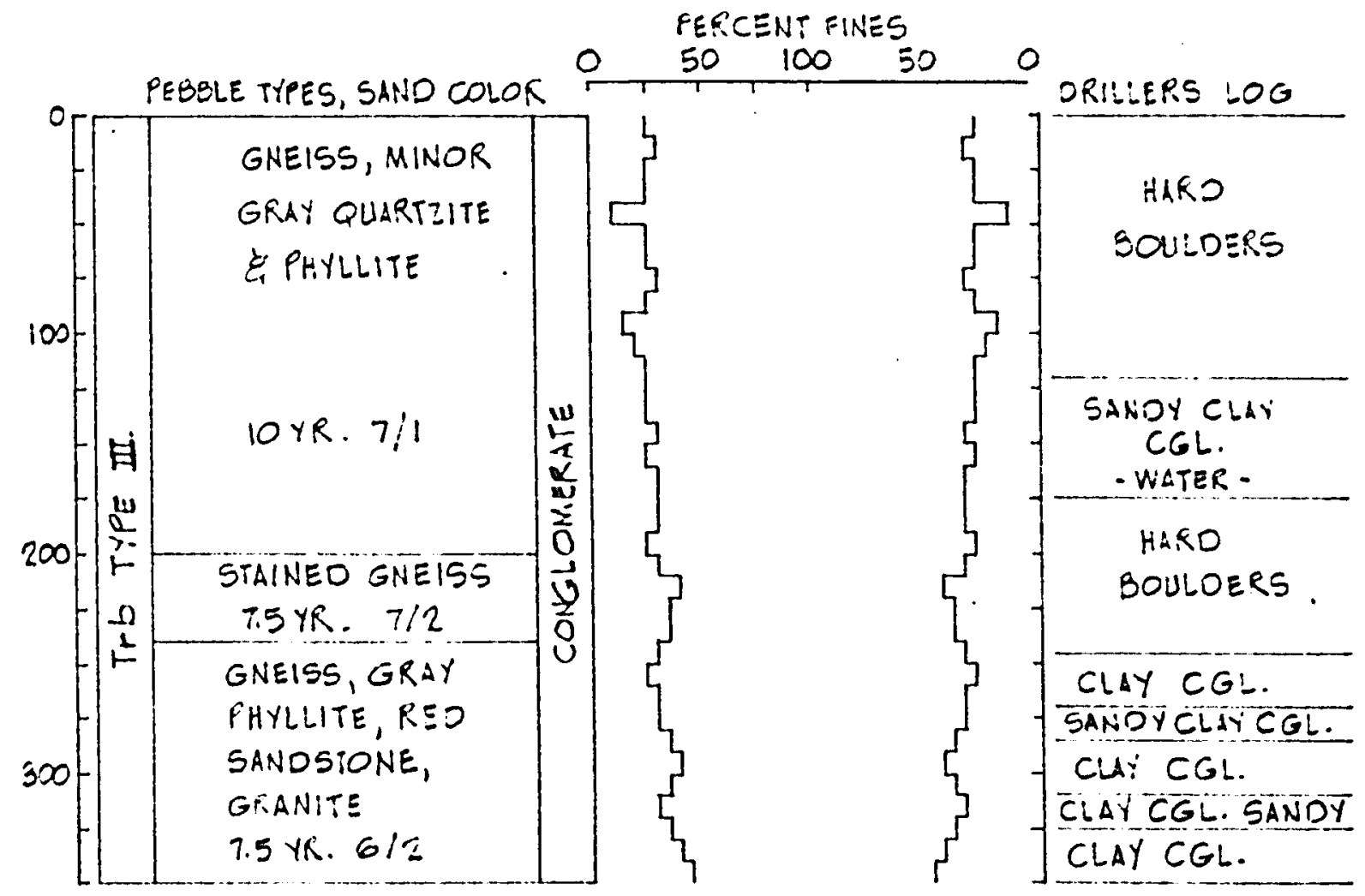

$\begin{array}{ll}\text { LOCATION } & (0.13 .15) 21 \text { ID } \\ \text { OWNER } & \text { MILLER } \\ \text { DRILLING CO. } & \text { FORSYTH } \\ \text { DRILLER } & \text { LEMONS } \\ \text { LAB.NO. } & 1864 \\ \text { DATE DRILLED } & \text { OCT.,1960 } \\ \text { WATER LEVEL } & 124.0 C T ., 60 \\ \text { SURFACE EXPOSURE } & \text { TS } \# \text { III }\end{array}$




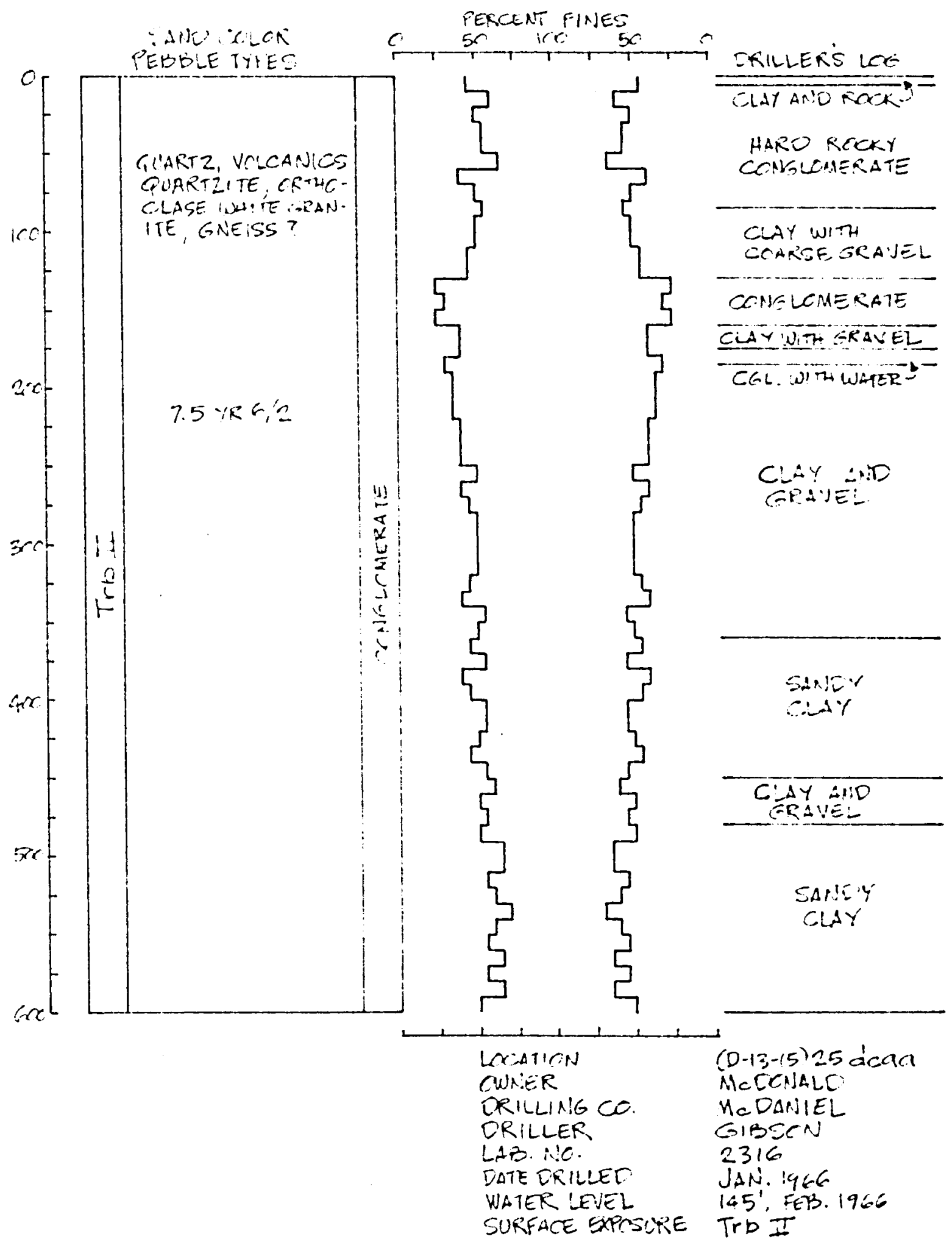


208
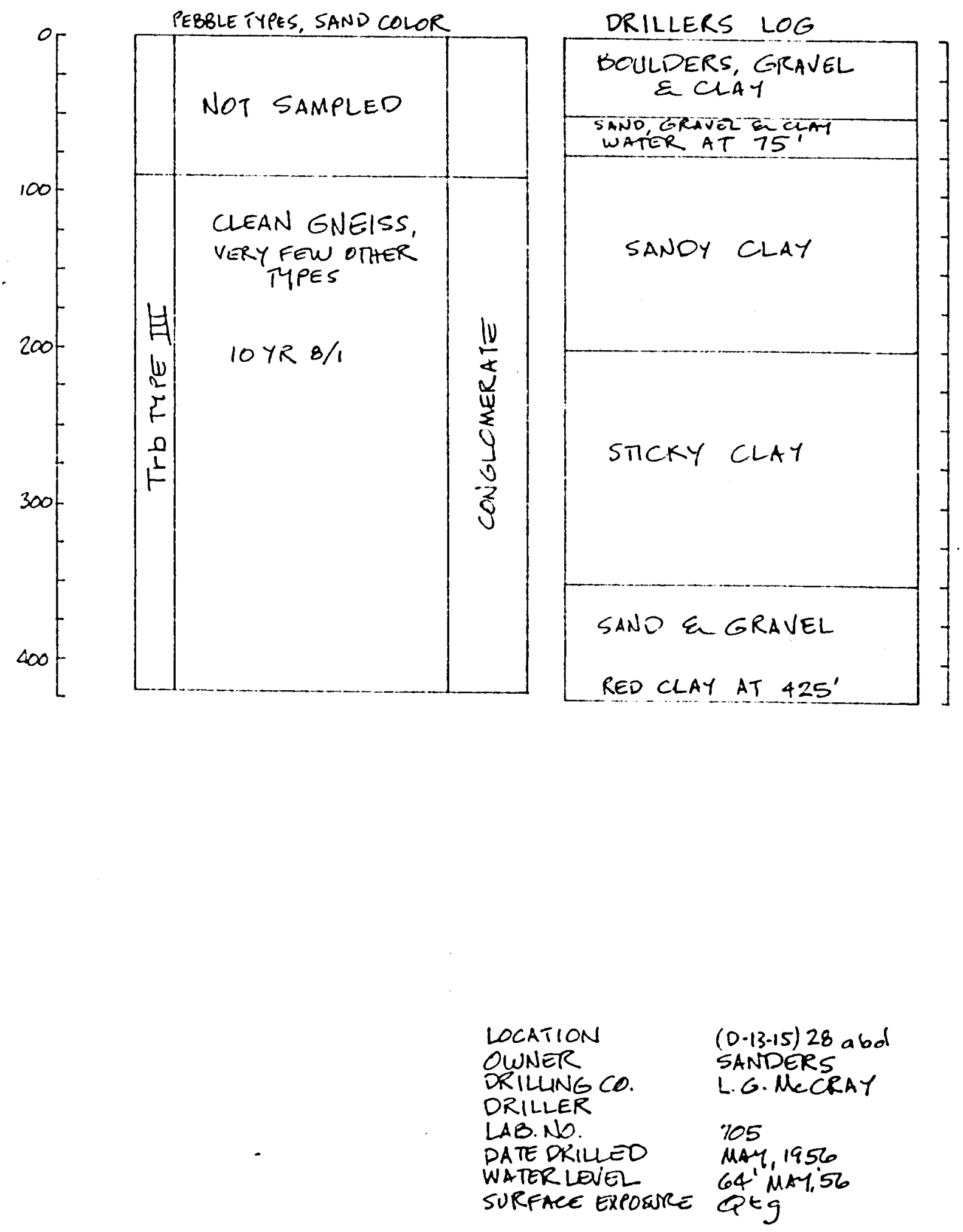

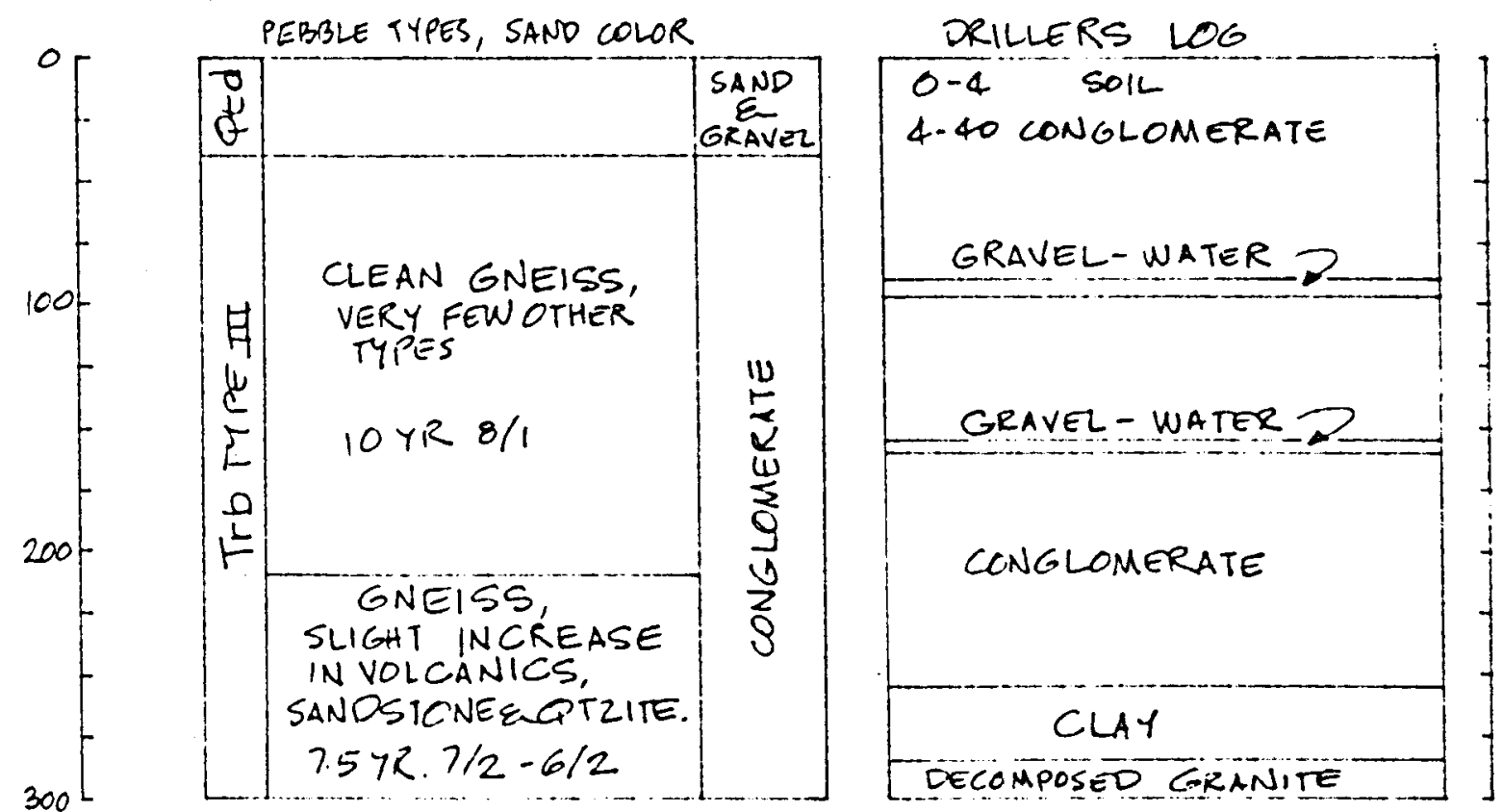

LOCATION CWNER

DRILLING CO.

DRILLER

LAO. NO.

DATE DRILLED

WATER LEVEL

SURFACE EXPOSURE
(D-13-15) 29 bac IMMACULATE HEART MCDANIEL

1385

NOV, 1961

$69^{\circ}$ 'NOV. 61

Qtg 


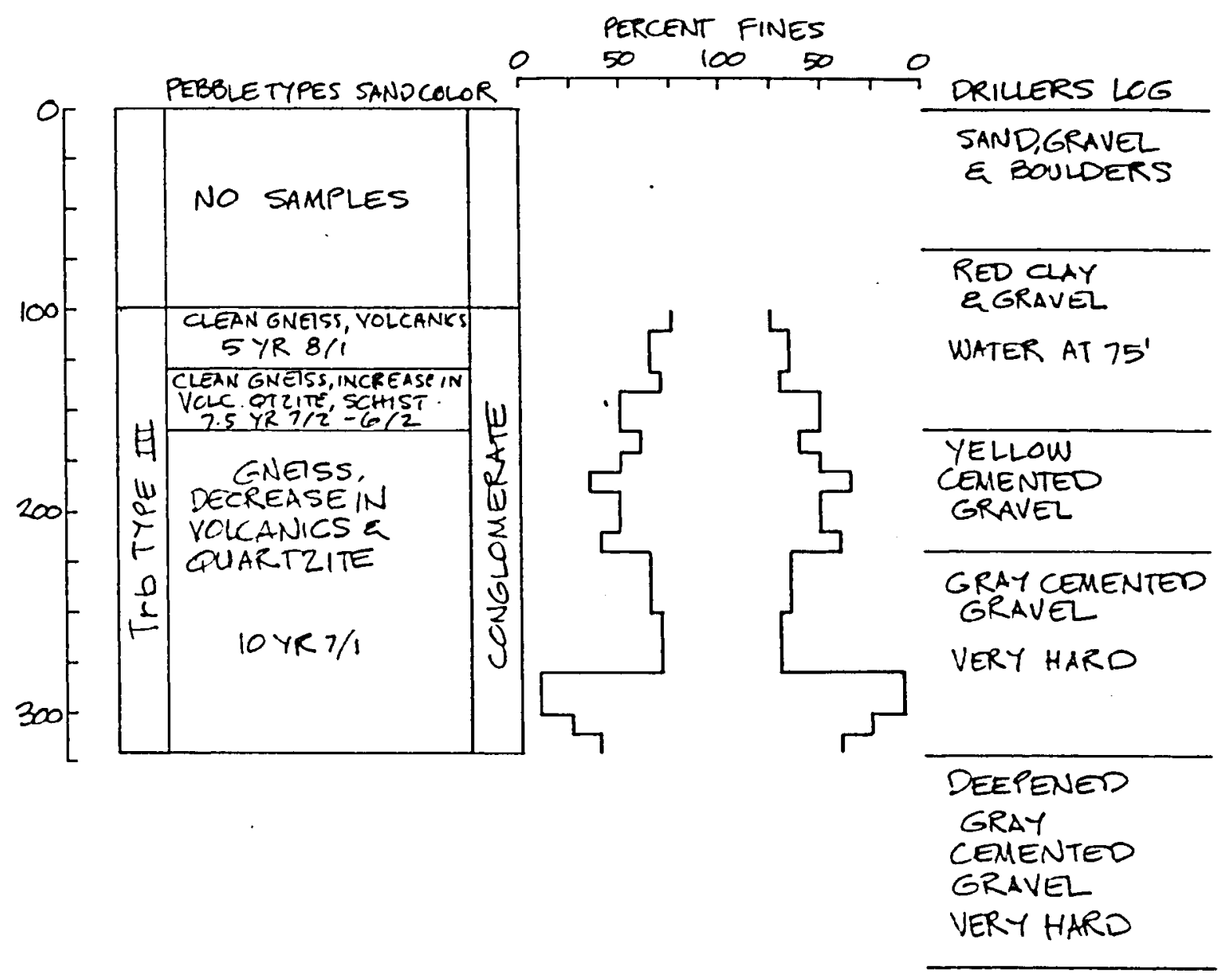

LOCATION

OWNER

DRILLING CO.

DRILER

LAB.NO.

DATE DRILLED

WATER LEVEL

SURFACE EXPOSURE

(D-13-15) 31 bdaa

TUCSON COUNTRY CLUB

PISTOR

THOMPSON

1908

SEPT 1964

$62 \cdot$ SETT, 1964 


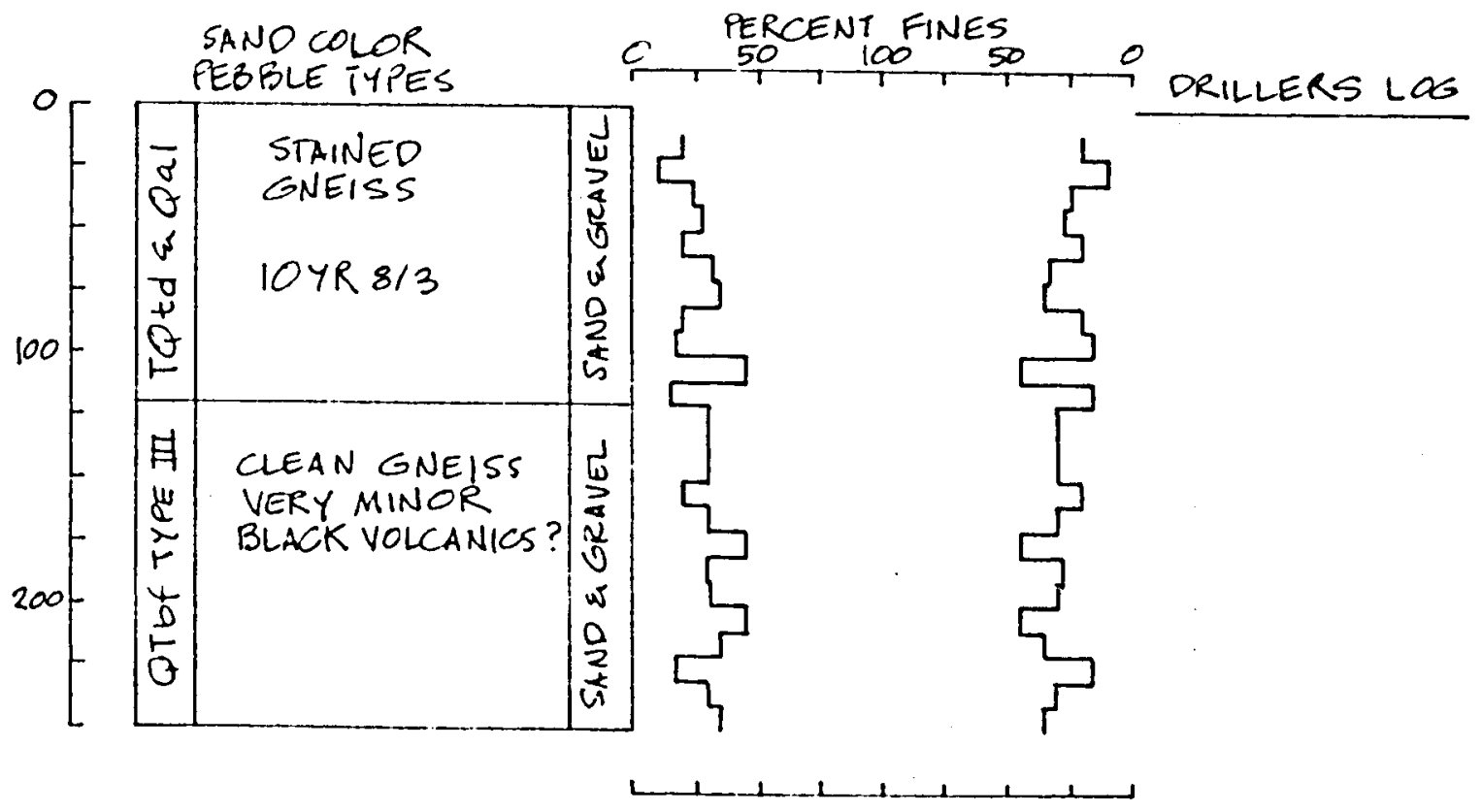

LOCATION

OWNER

DRILLINGCO. DRILLER

LAB. NO.

DATE DRILLED

WATER LEVEL

SURFACE EXPOSURE
$(0.13-15) 32 a a b$

ARIR. MAINT

MAGNUS

1776 1964 


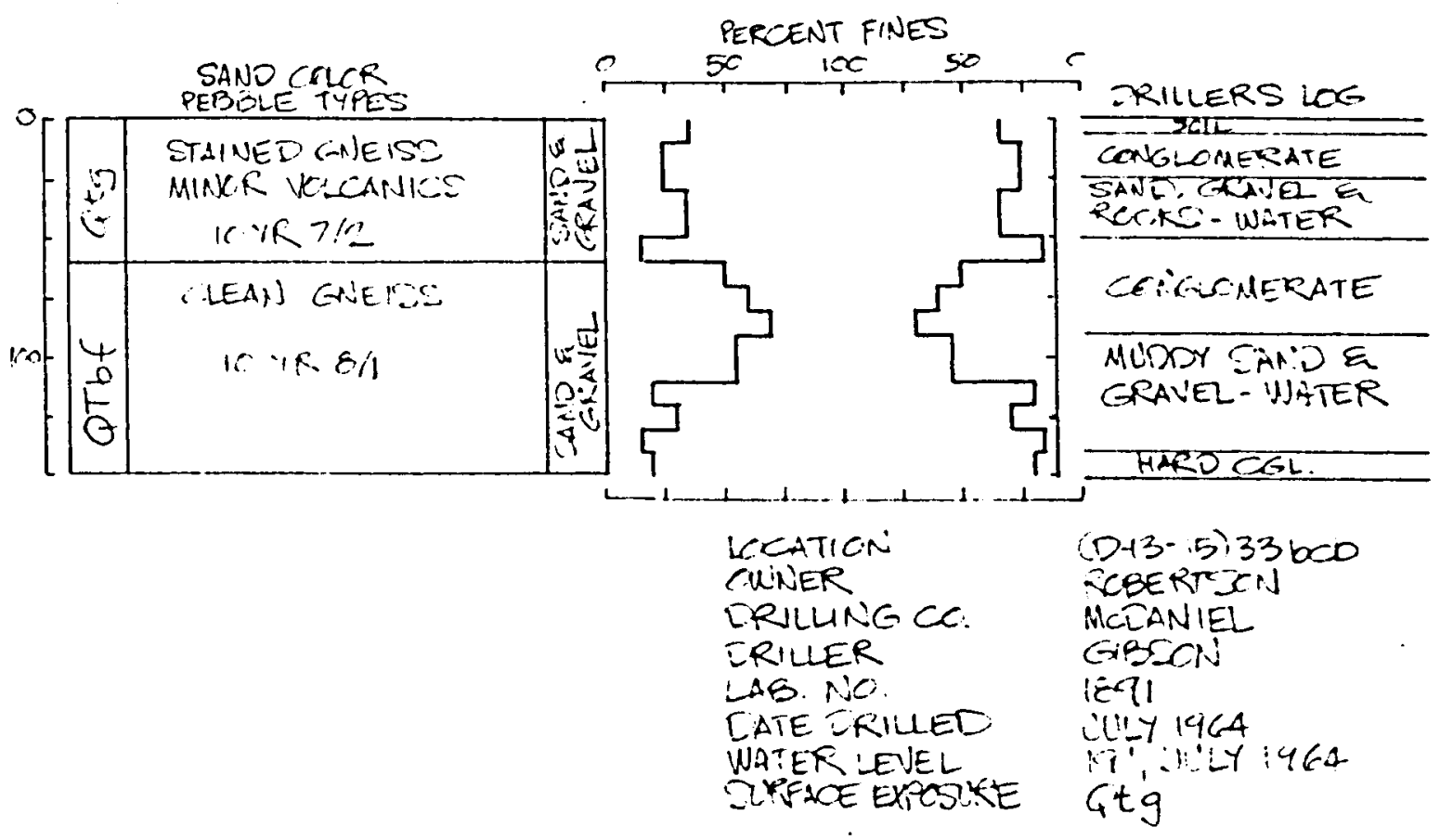




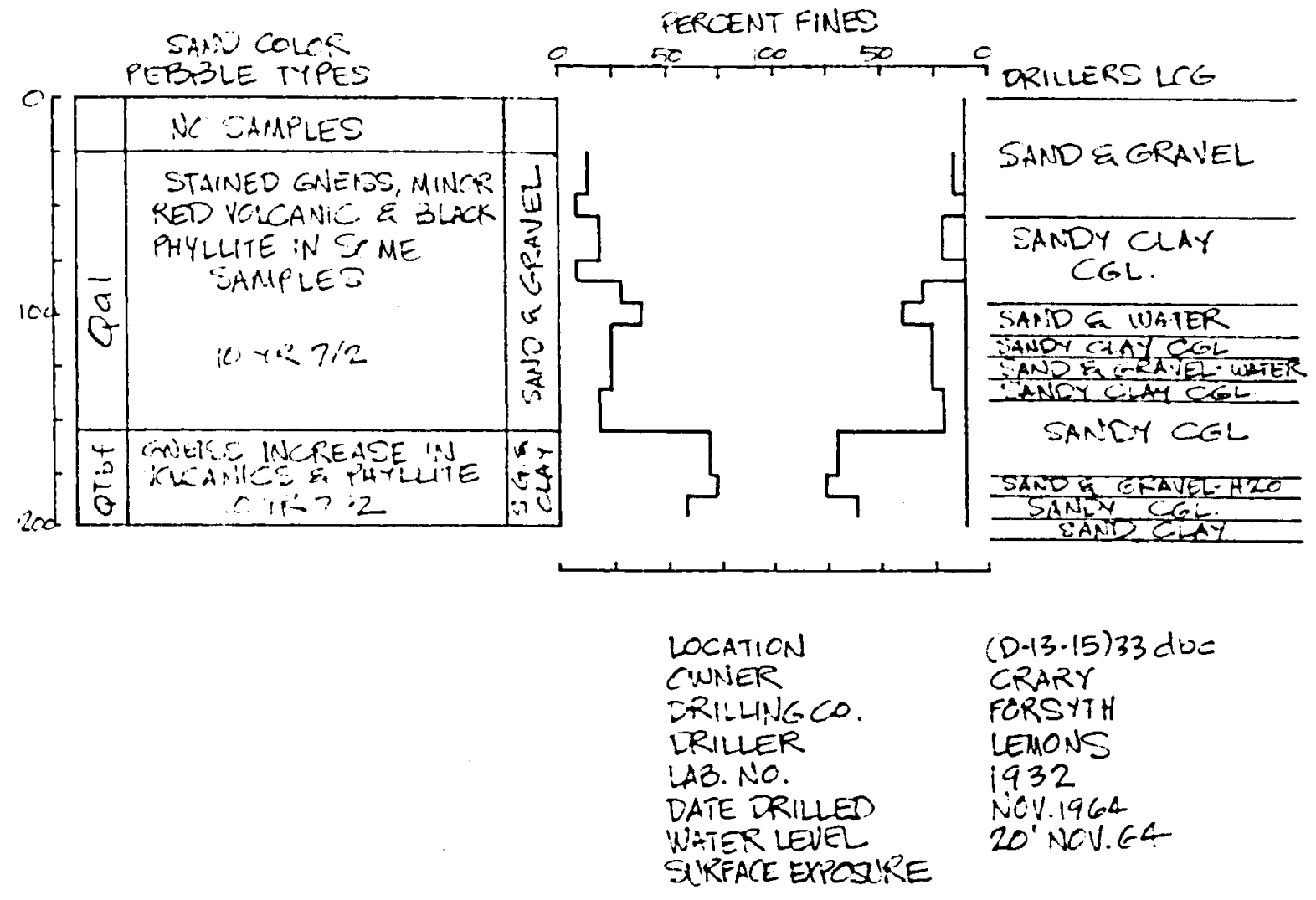




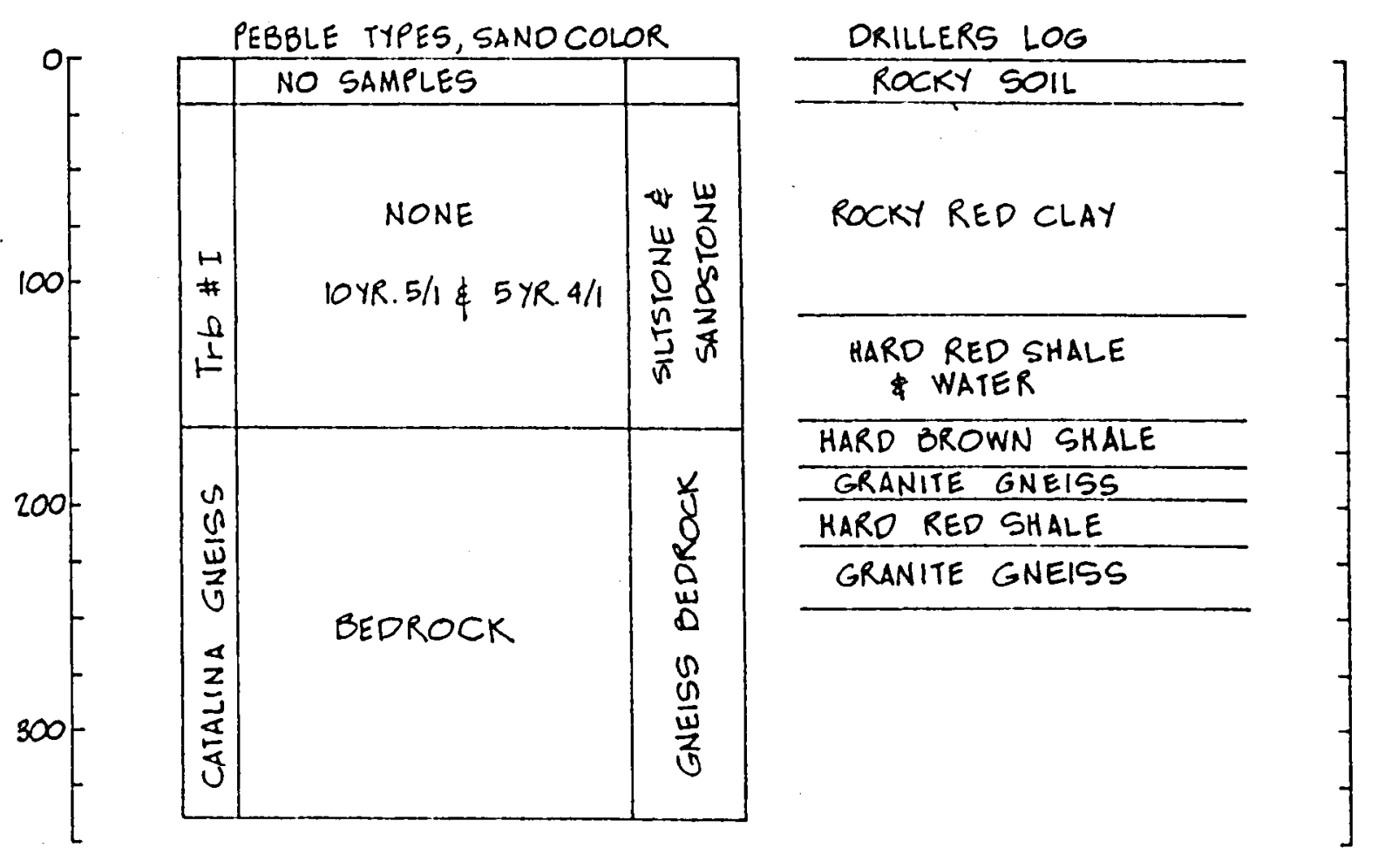

LOCATION

OWNER

ORILLINGCO.

ORILLER

LAB. NO.

DATE DRILLED

WATER LEVEL

SURFACE EXPOSURE
$(D-13-16) 28$

KOMERAK

MCDANIEL

ANDERSON

2169

MARCH, 1965

$80^{\prime}$ MARCH, 65

Qtg 


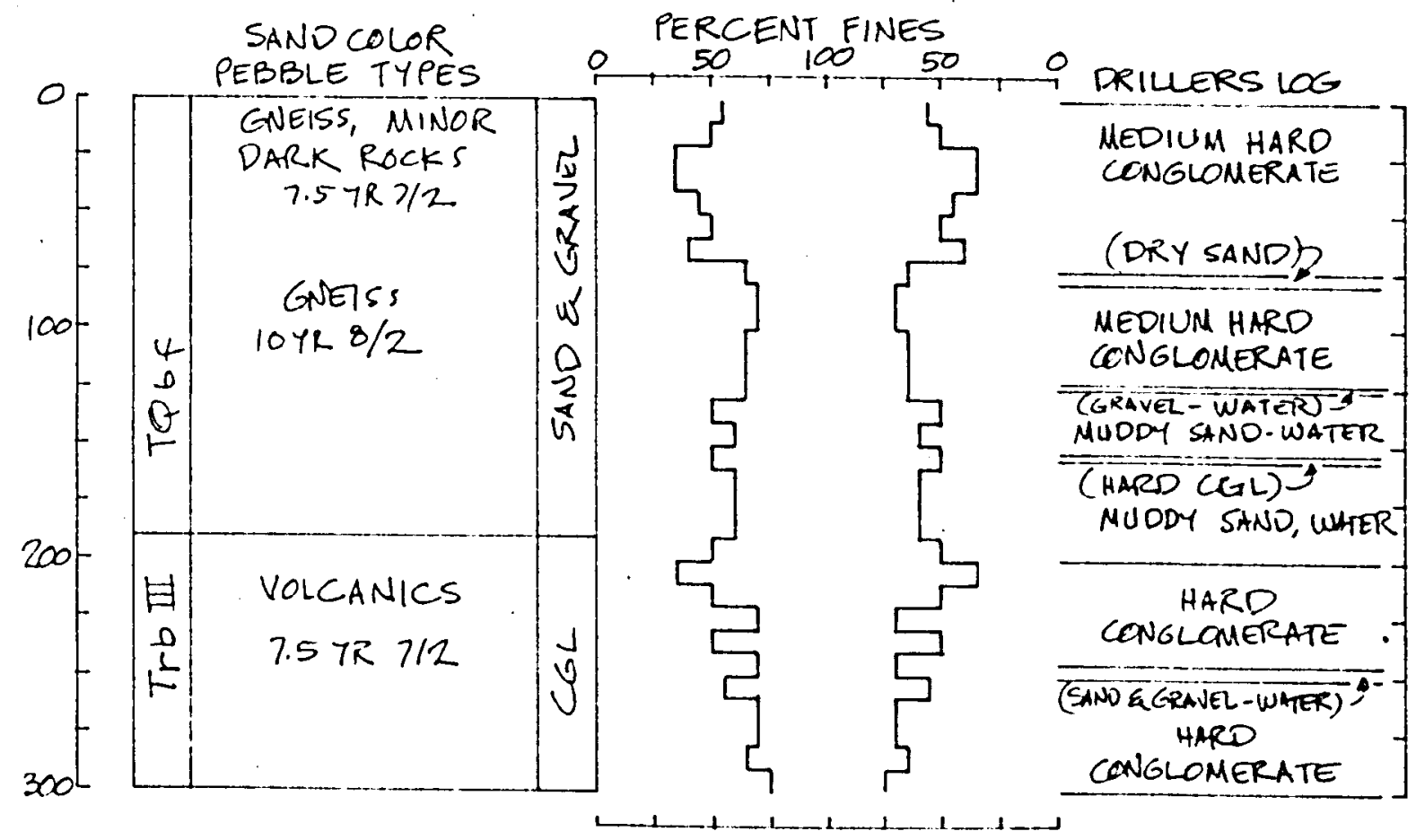

LOCATION

OWNER

DRILUNG CO.

DRILLER

LAO.NO.

DATE DRILLEO

WATER LEVEL

SURFACE EXPOSURE

$(D-14-13) \mid b b b$

MARILYN MOTEL

MCOANIEL

HEALOT

$18 B 8$

JUNE, 1964

109' JUNE'64 


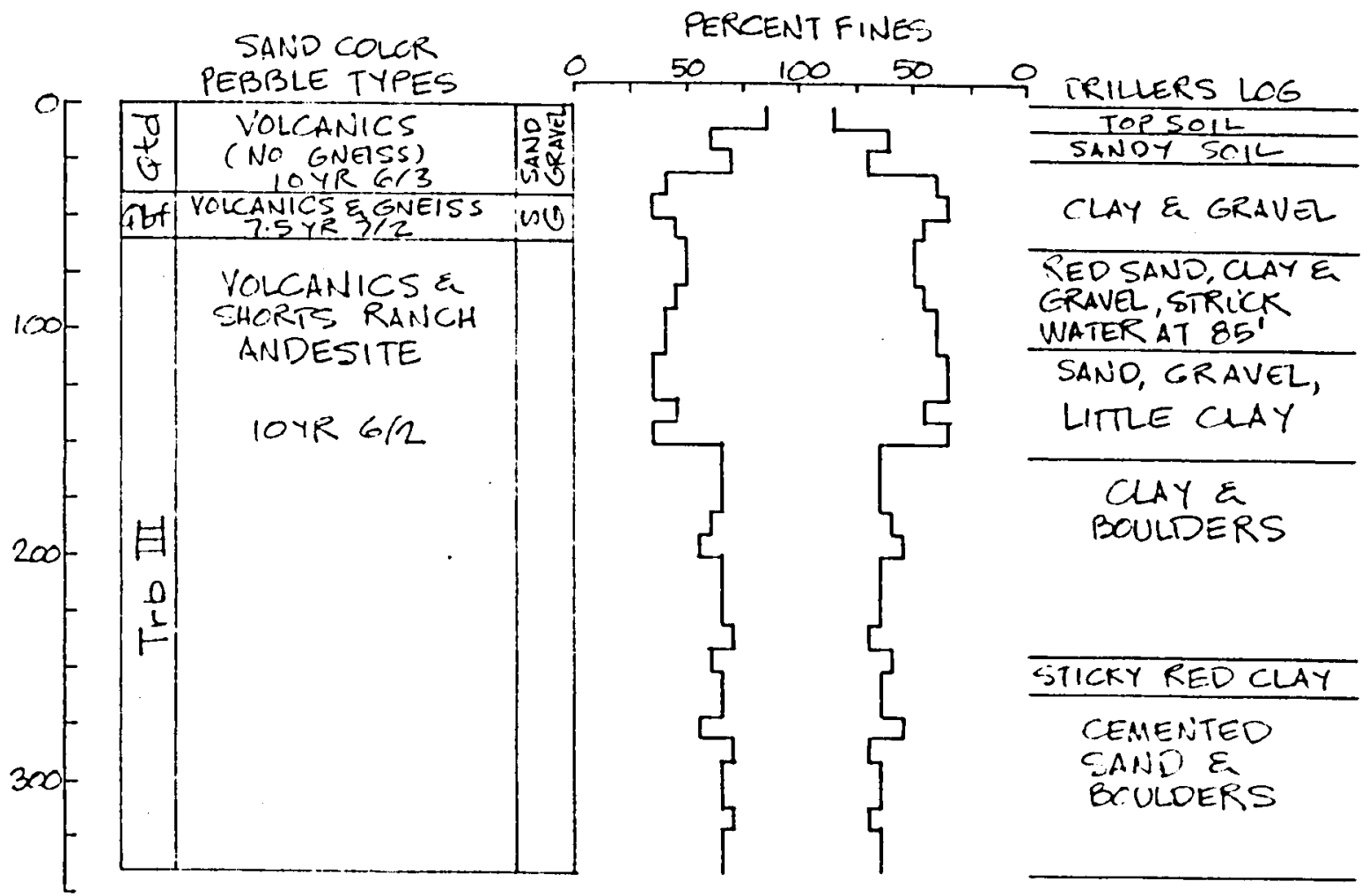

LCCATICN CNNER

WRILLIRGCO.

DRILLER

LAB.NC.

SATE IRILLED

WATER LEVEL

SURFACE EXPOSURE

$(0-14-13) 3$ dcba TULLY SCHCOL PISTOR GASTELUM

1966

MARCH, 1965 85', MARCH 65 


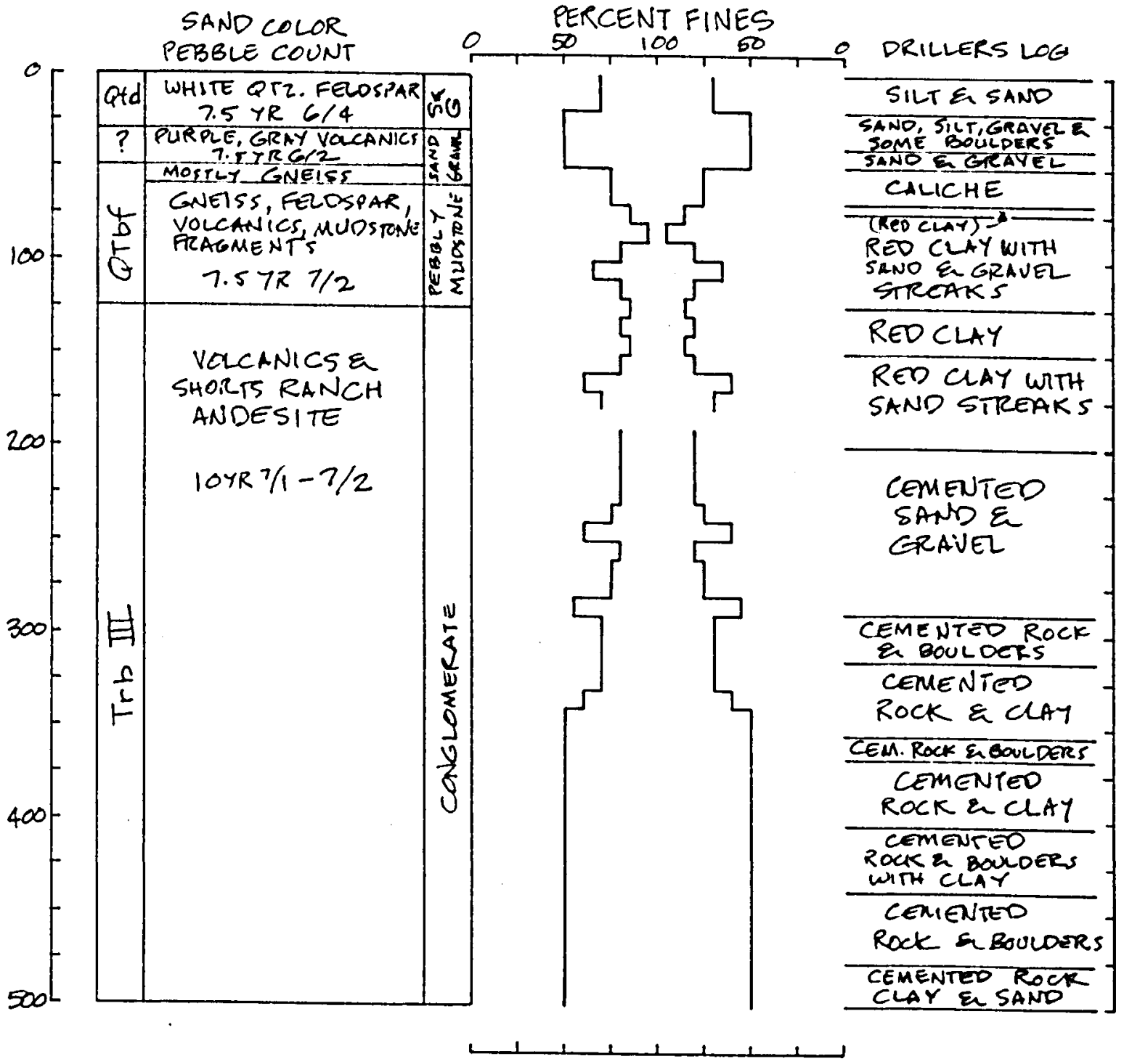

LOCATICN

OUNER

DRILLING CO.

DRILLER

LAB. NO.

DATE DRILLED

WATER LEVEL.

SLRFACE EXPCSURE
$(0-14-12) 11$ dra

TLKCSON A-34

BCRING, A.L.

DIAZ

1921

4116.1964

$95^{\prime}$

$4 \operatorname{tg}$ 


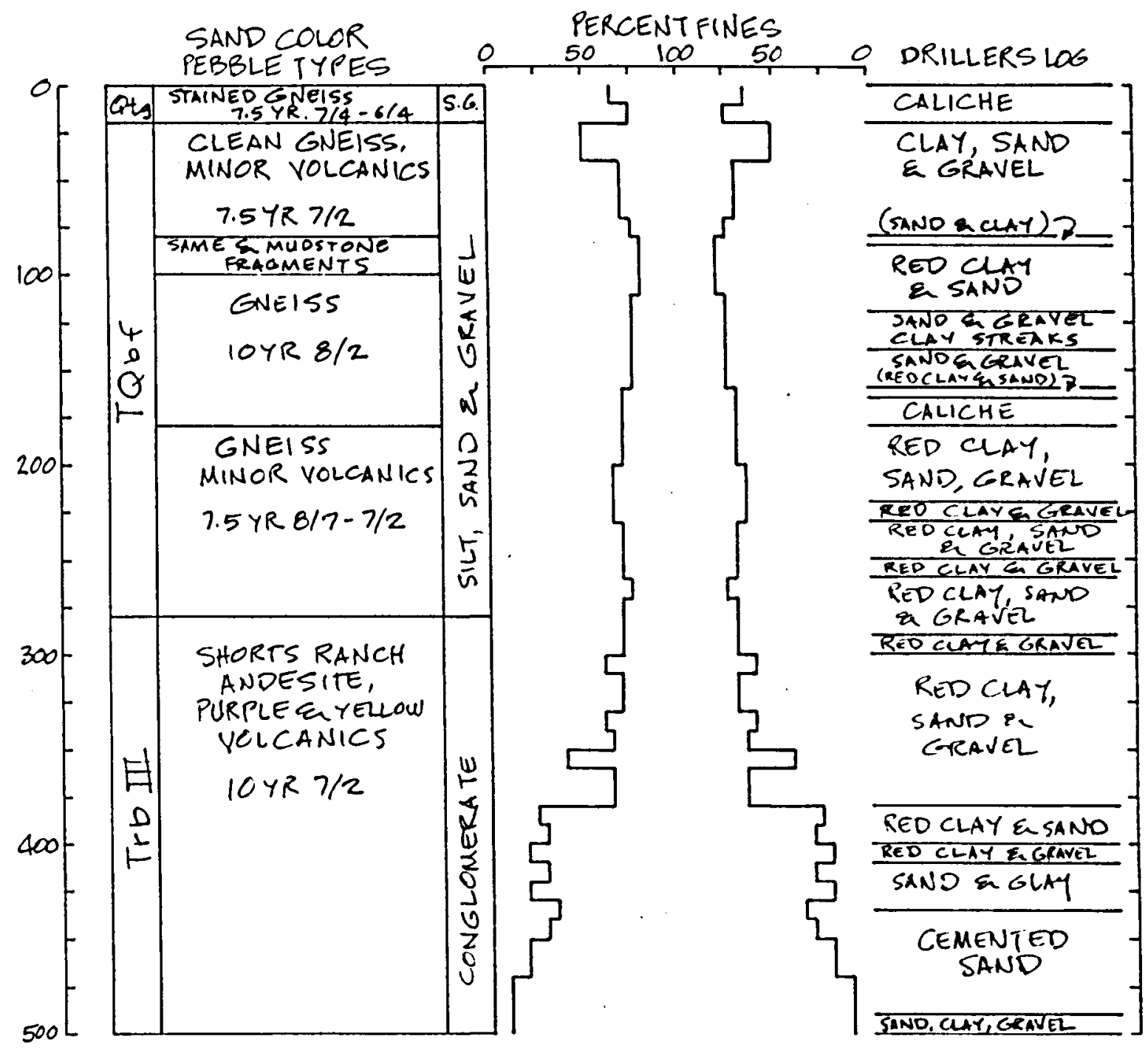

LOCATION

OWNER

DRILLING CO.

DRILLER

LAB. NO.

DATE ORILLED

WATER LEVEL

SURFACE EXIOSURE
$(0-14-13) 12 d c b a$

TUCSON A-33

A.L. BORING

DIAZ

1935

DEC, 1964

G' JANG5 


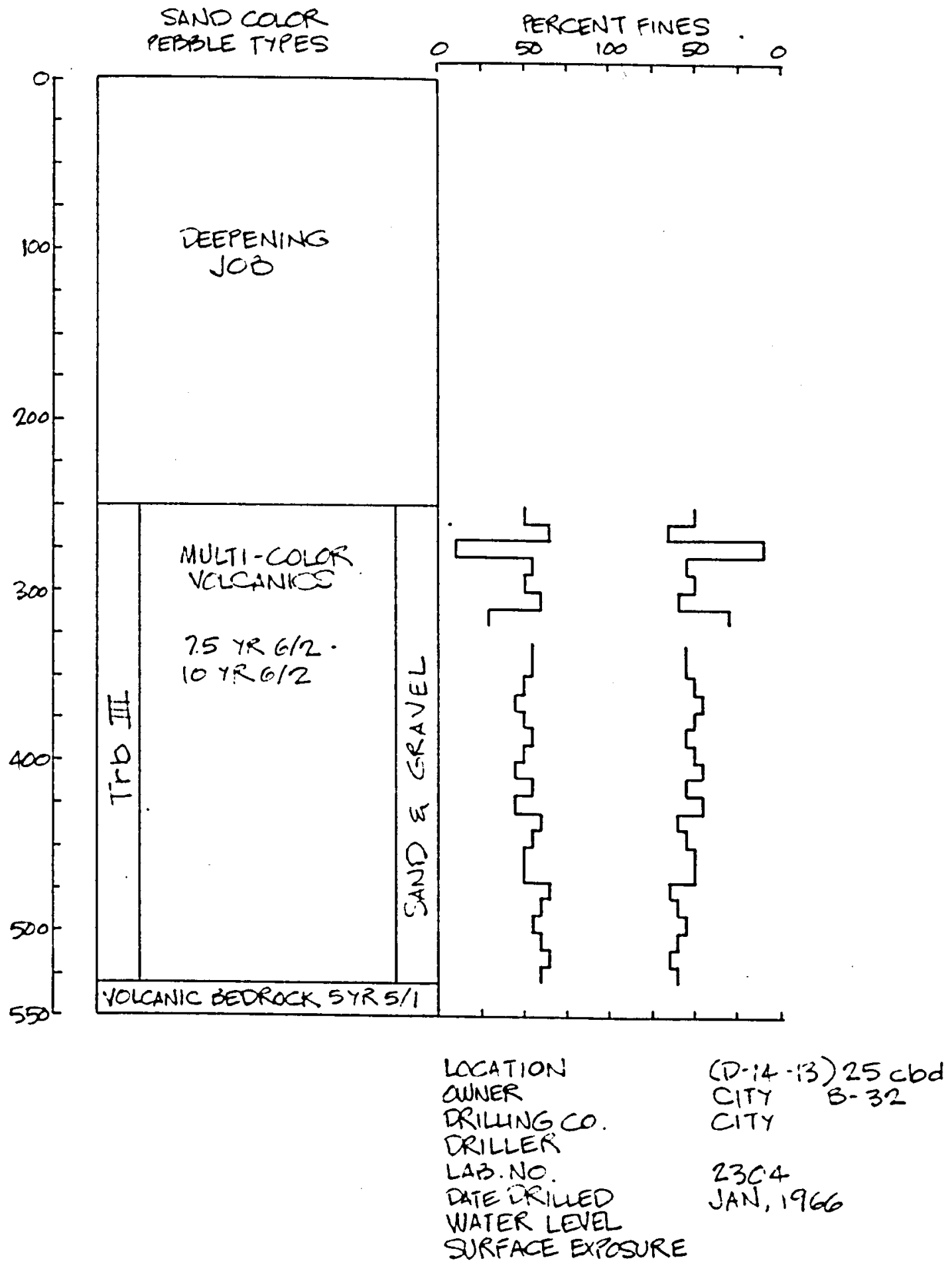




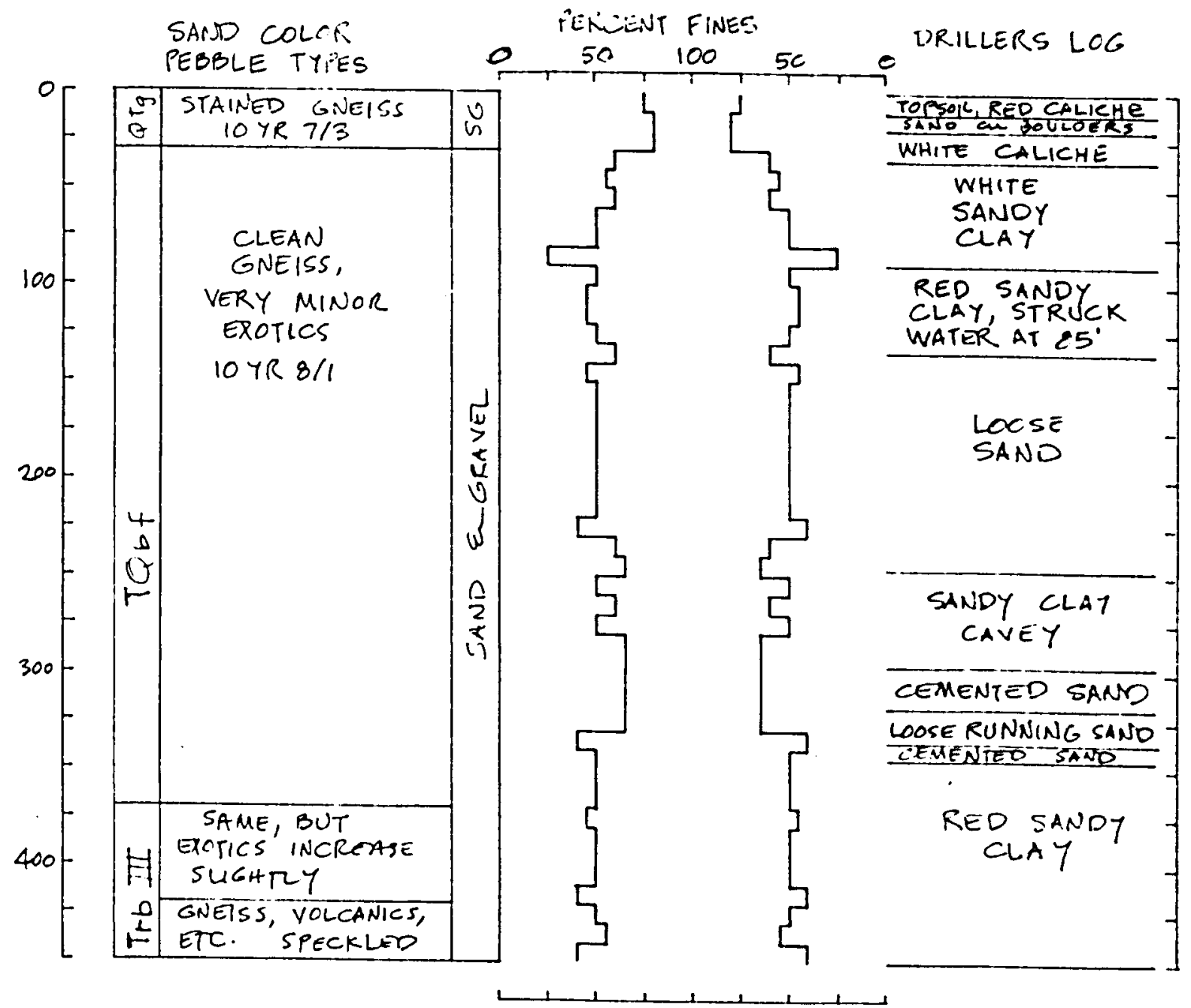

LOCATION

OWNER

DRILLING CO.

DRILLER

LAB. NC.

DATE DRILLED

WATER LEVEL

Sirface exposure
$(0.14-14) 2$ a acc TOWNSEND SCHOCL PISTOR GASTELUM 1943 


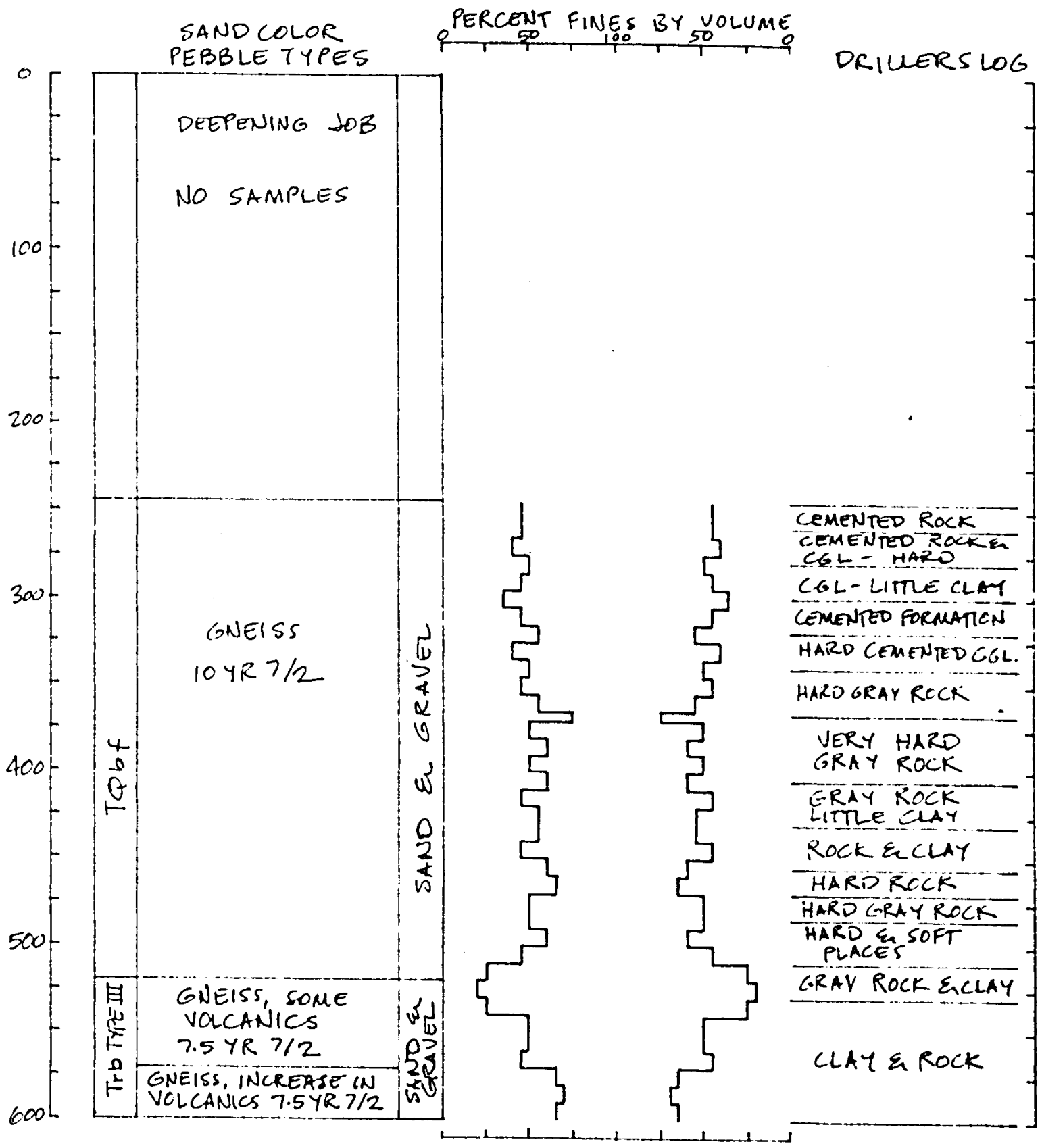

LOCATION OWNER

DRILUNG CO.

DRILLER

LAB. NO.

DATE DRILLED

WATER level

surface expCSURe
$(0-14-14) 2$ dcaa CITY of TUCSON C-48 ARIR. MAINT. POSEY in 44 


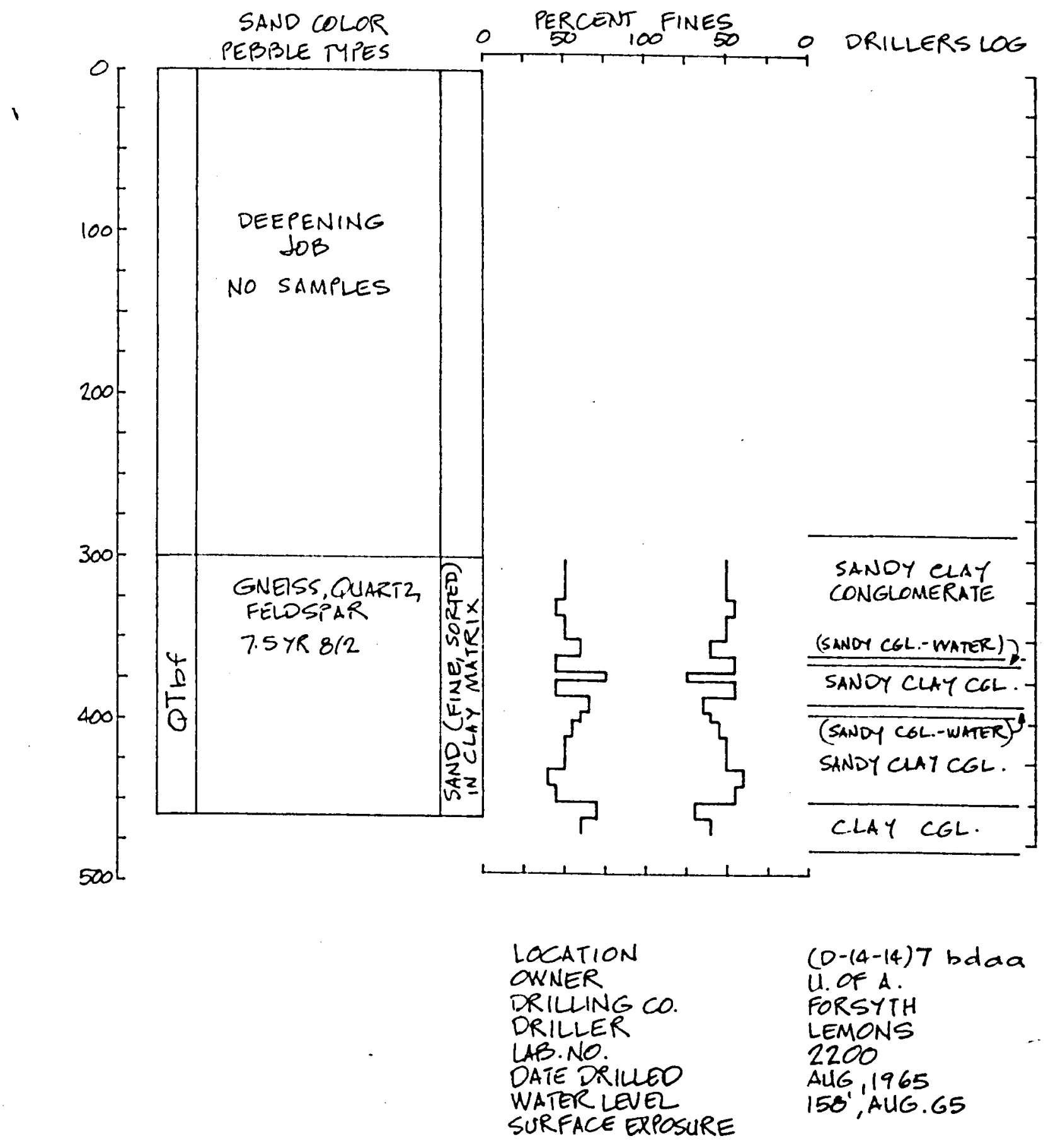




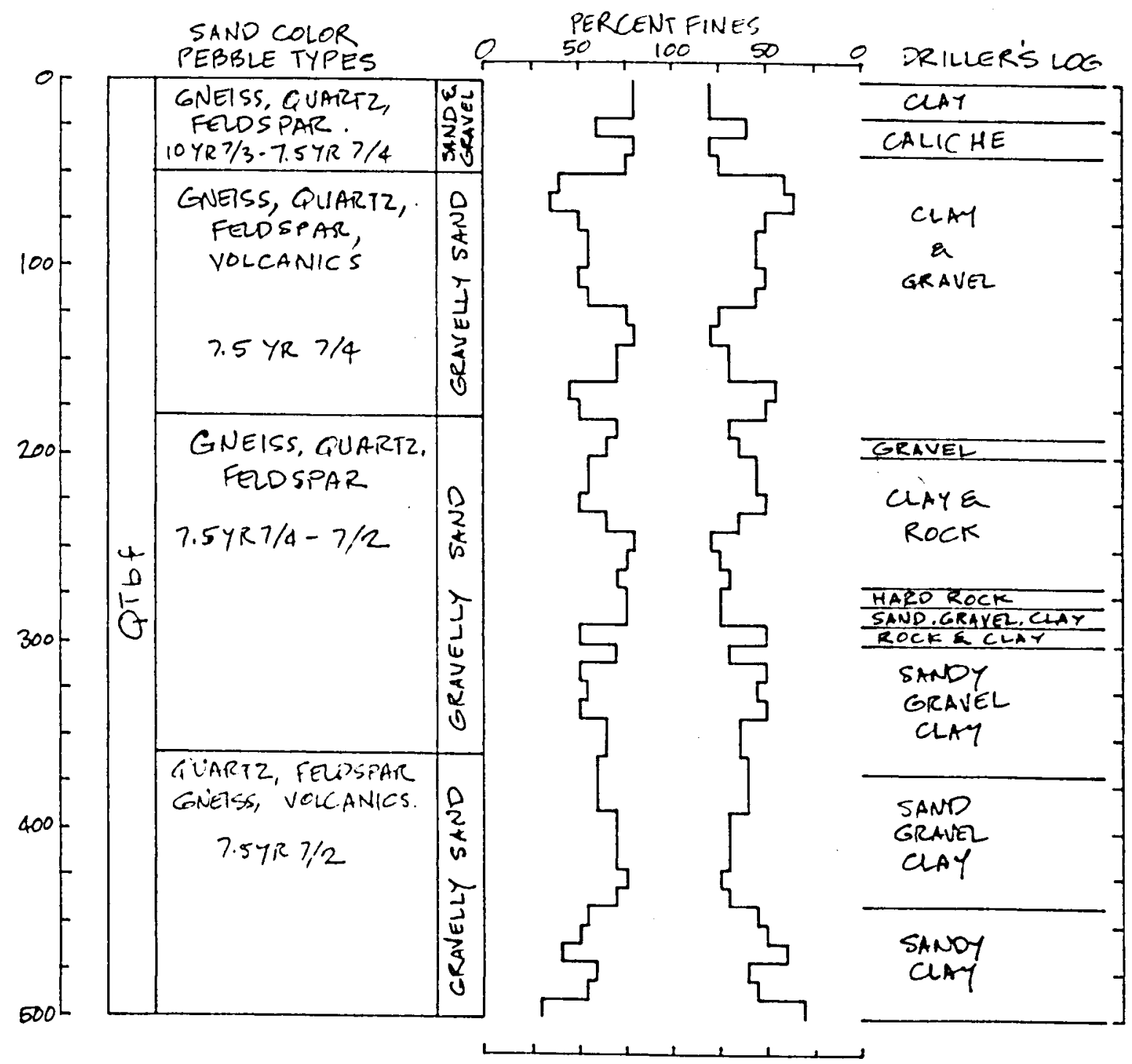

LECATION OWNER

DRILLINGCO. DRILLER

LAB. NO.

DATE ORILLED

WATER LEVEL

SURFACE EXPOSURE
$(0-14-14) 20$ bbaa

TUCSON B-78

BCRING

2117

$M+4,1965$

125

Qbftg 


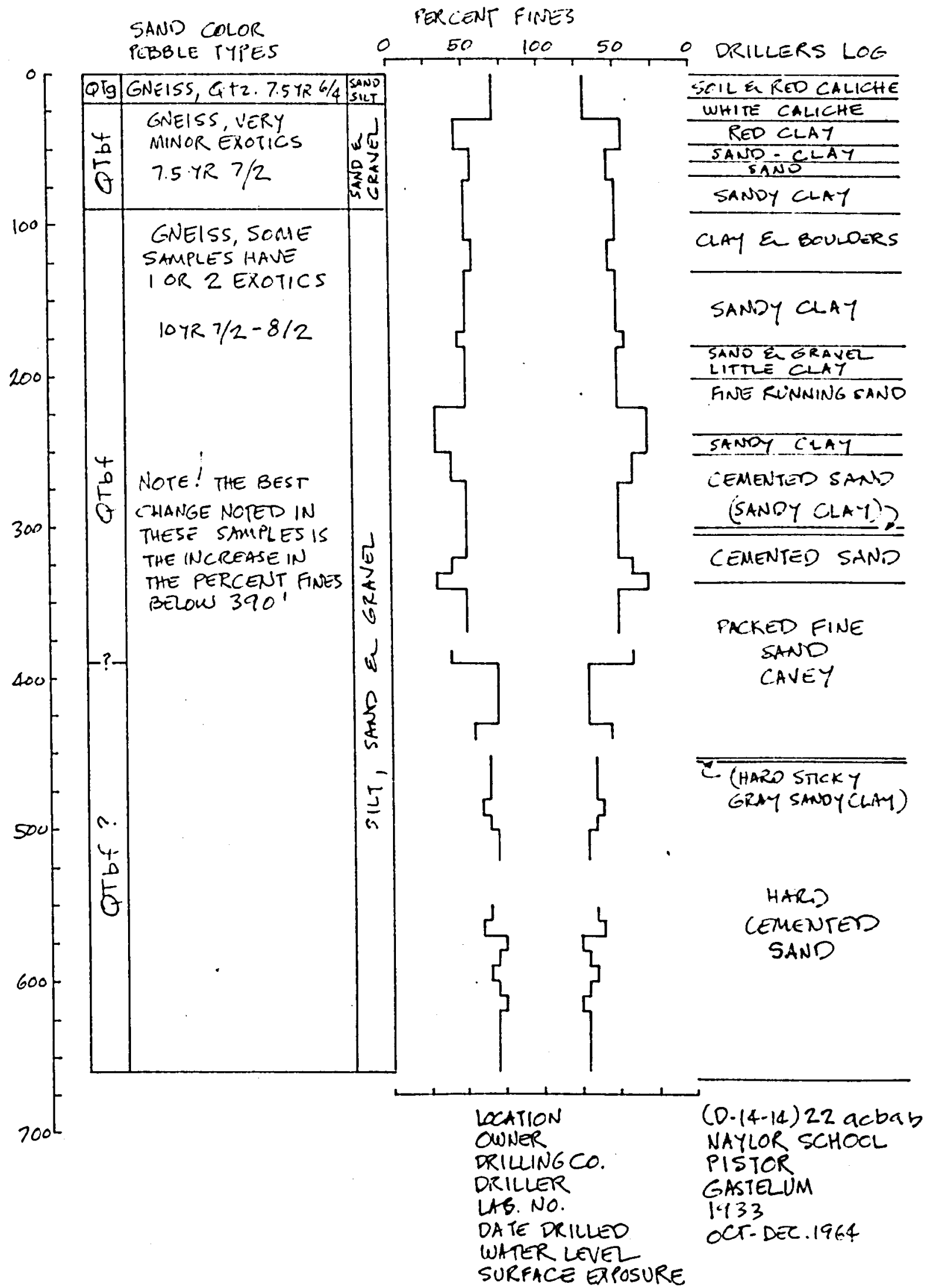




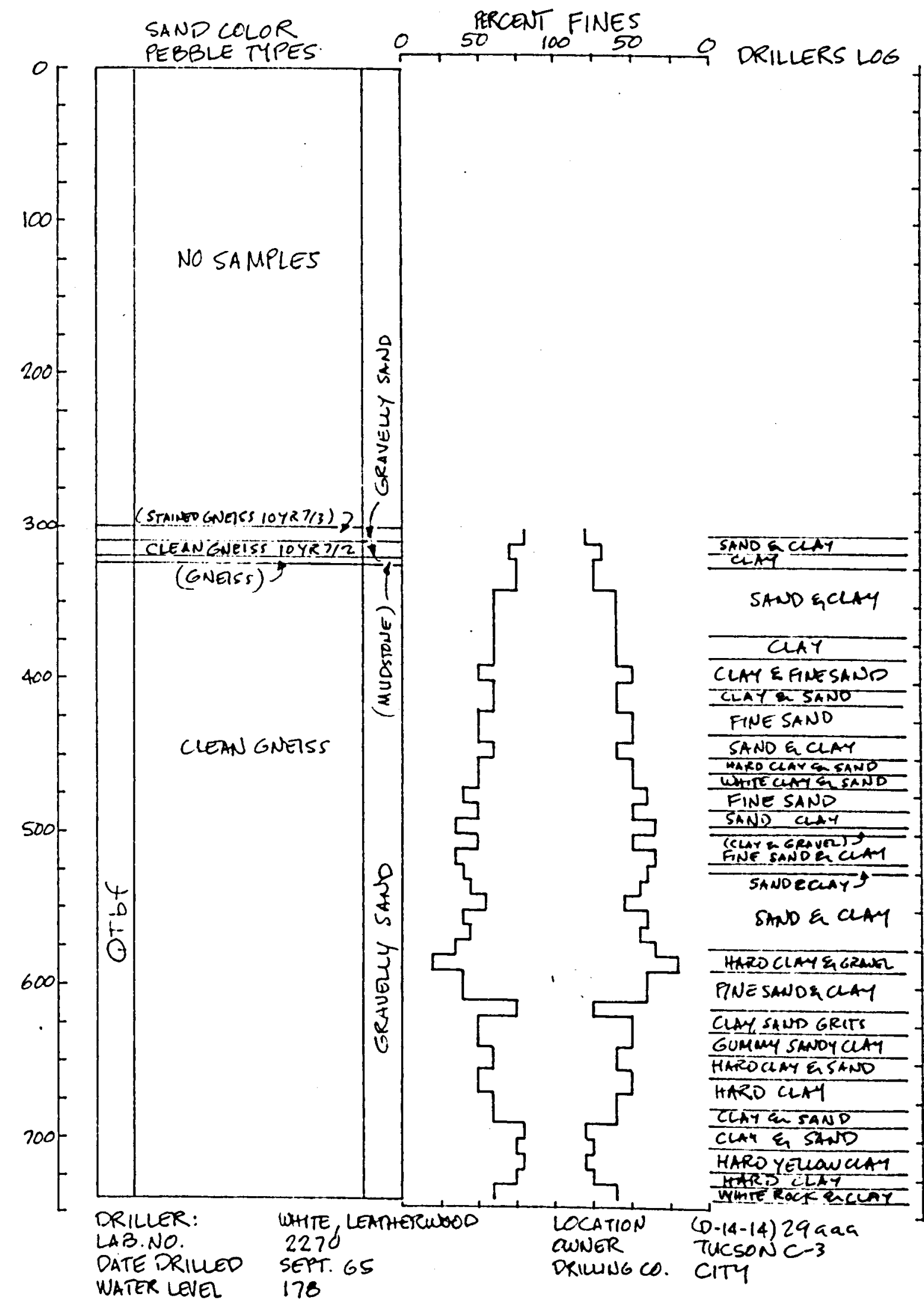




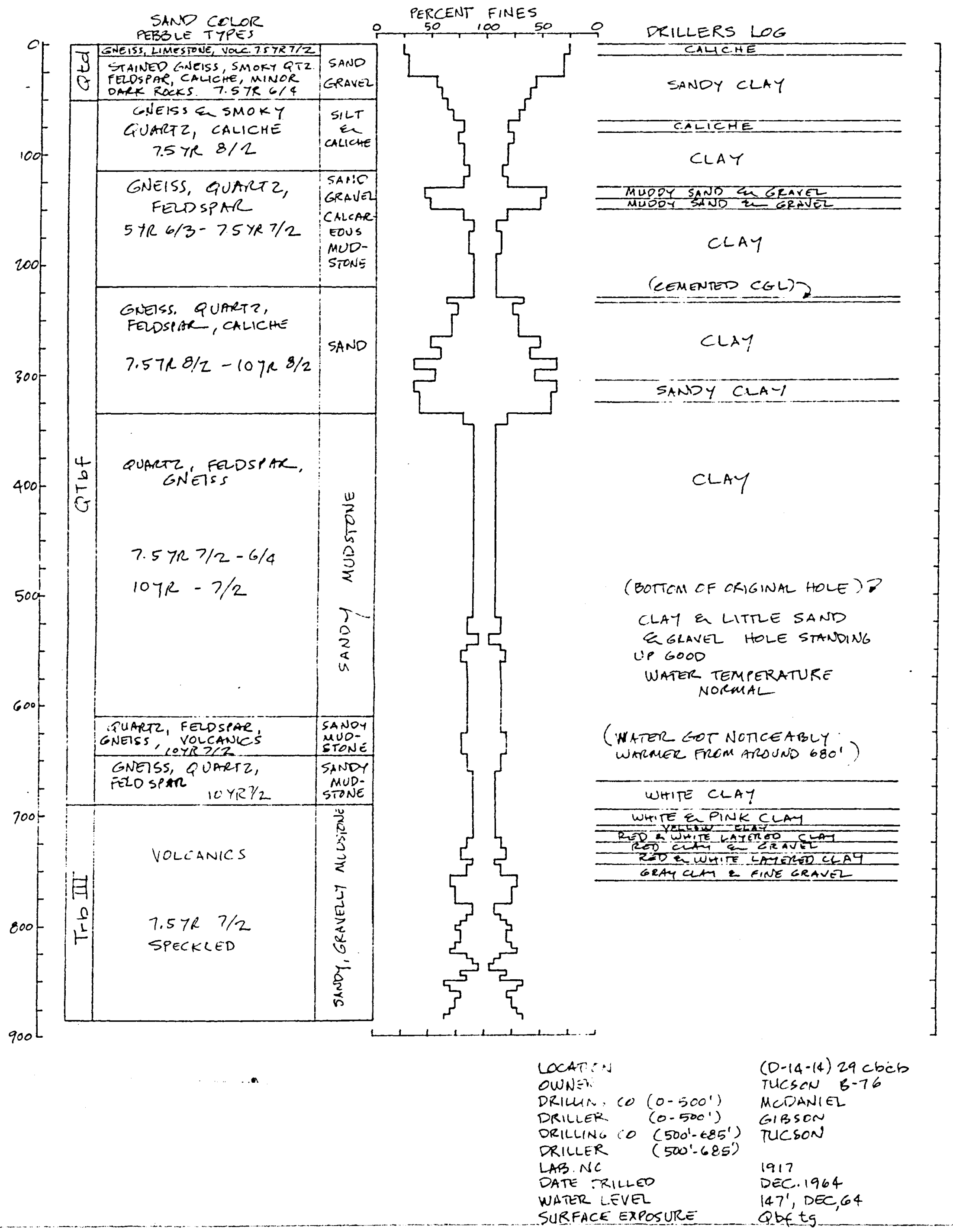



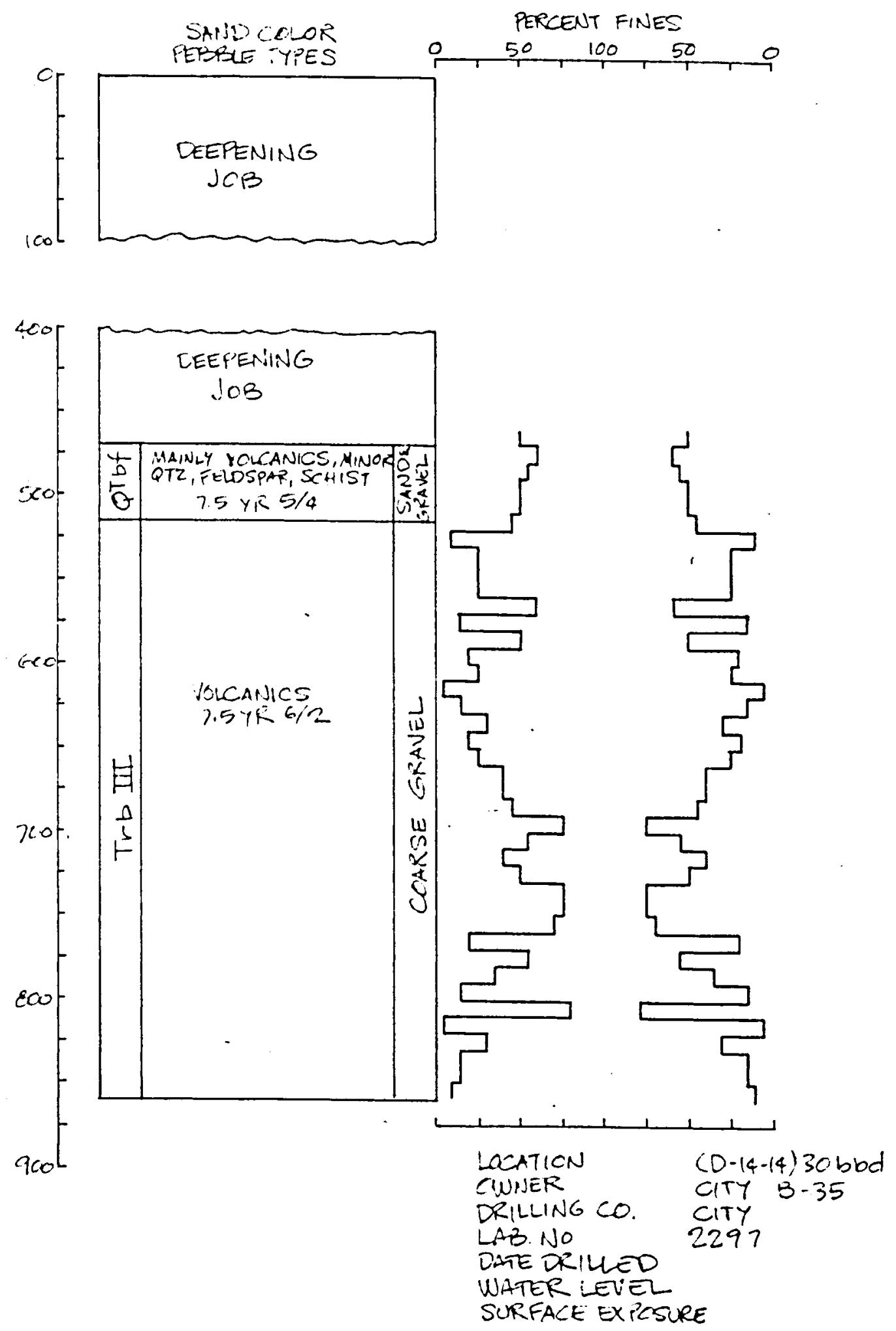


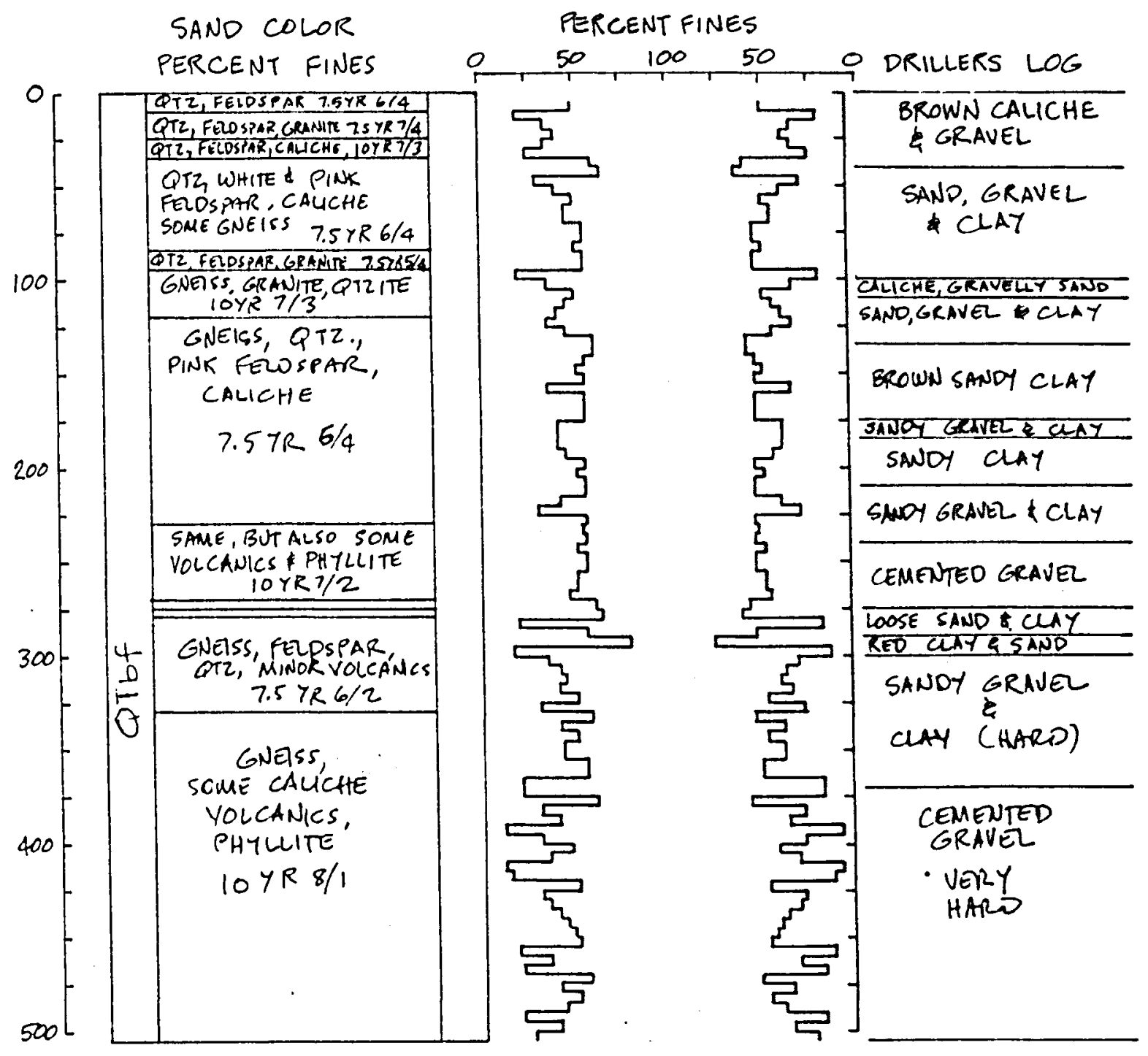

LOCATION

OWNER

DRILLING CO.

DRILLR

LABNO.

dATE dRIlled

water level

SURFACE ERPOSURE
$(0-14-14) 36$ ccab CORPS OF ENGINEERS PISTOR

1304

JULY, 1961

$246^{\circ}, A \cup G, 1961$ 


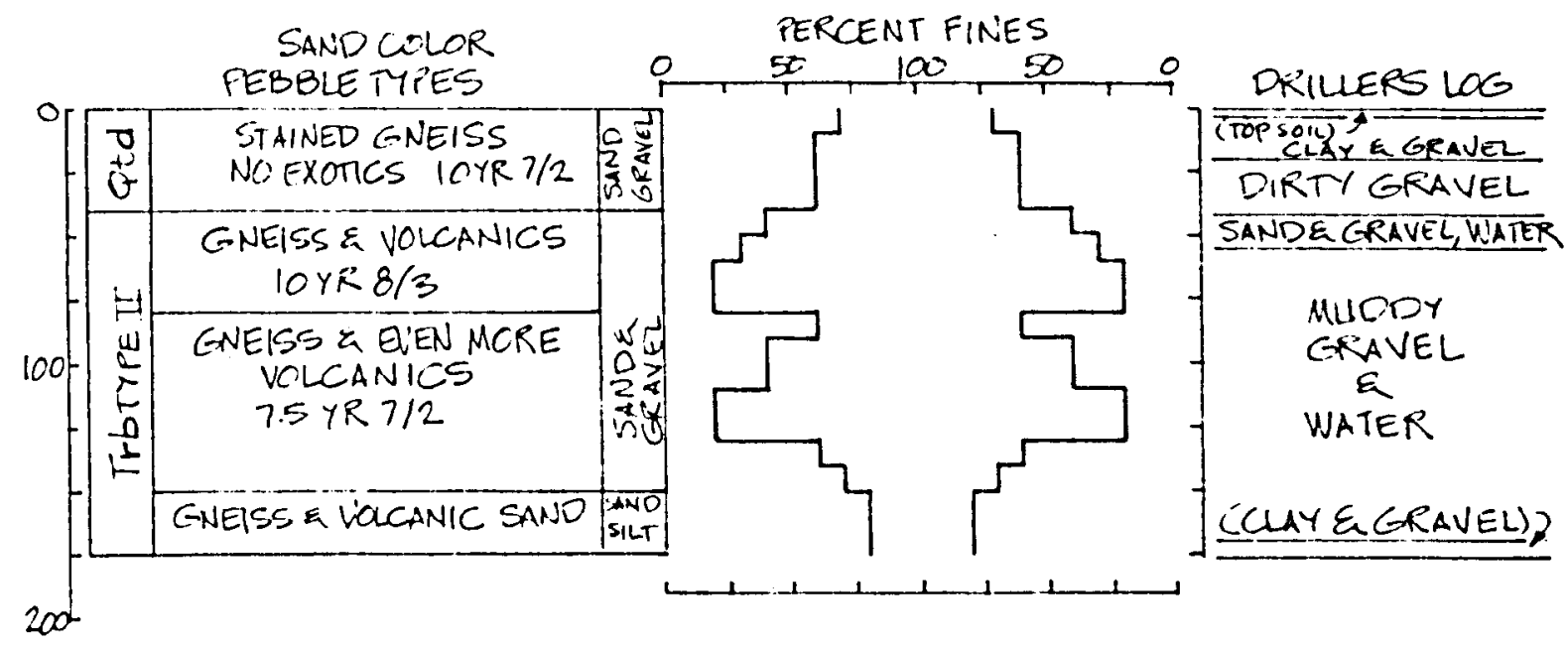

LOCATICN

OWNER

DRILLING CO.

ORILLEF:

LAB.NO.

DATE DRILLED

WATER LEVEL

SURFACE CUTCRCP
$(D-14-15)$ laba

SCANNELL

a. a MLidanilel

GIBSON.

1892

IIILY 1964

$32^{\prime}$ JULY 1964

TERRACE GRAVEL 


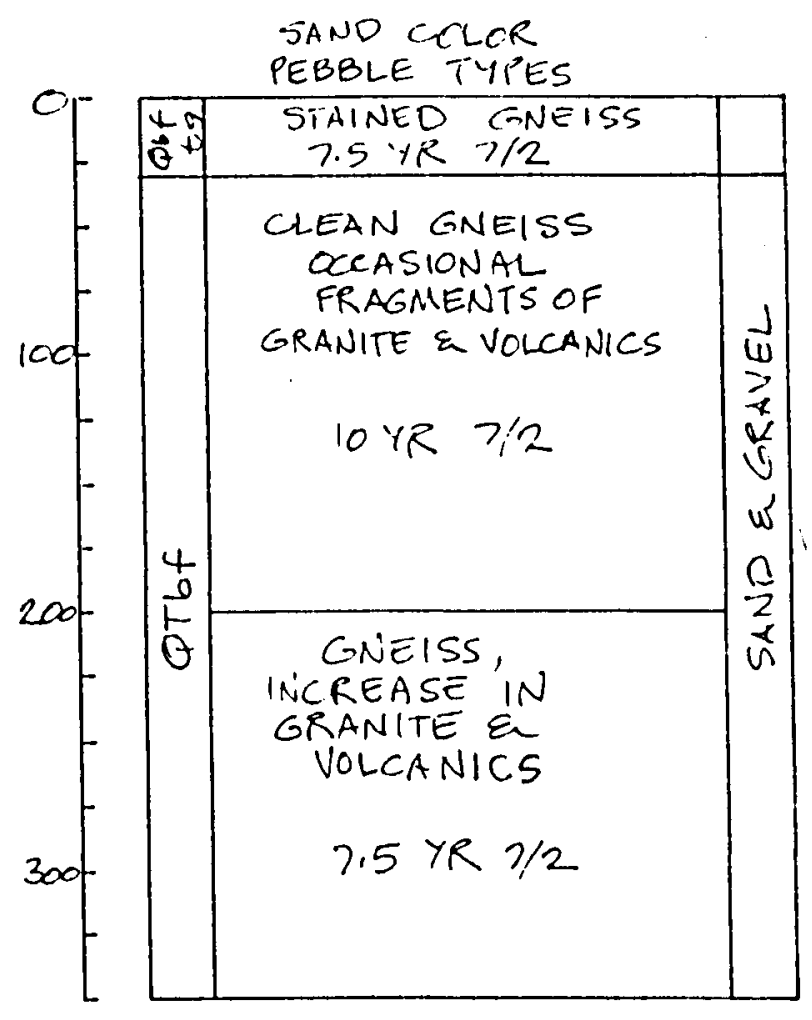

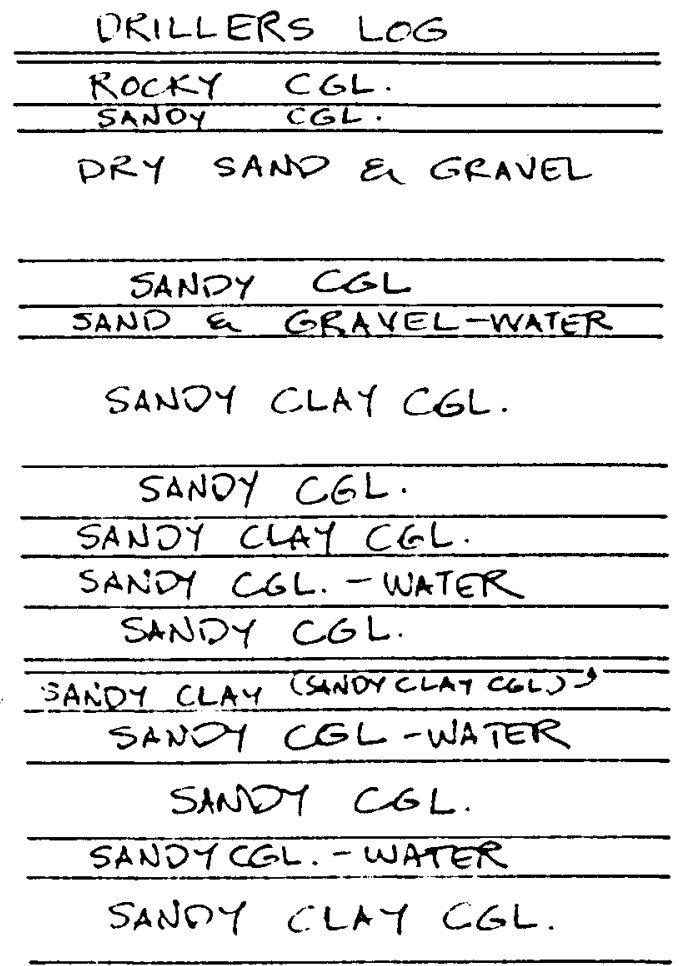

LOCATION

CWNER

ORILLNGCO

DRILLER

LAB. NO.

DATE RRILLET

WATER level

WRFACE ERCSLIRE
$(D-14-15) 3 \mathrm{cdc}$ DESERT PALAIS PARK FERSYTH

BANGHART

1366

APRIL 1961

95' ATRIL GI

coftg 


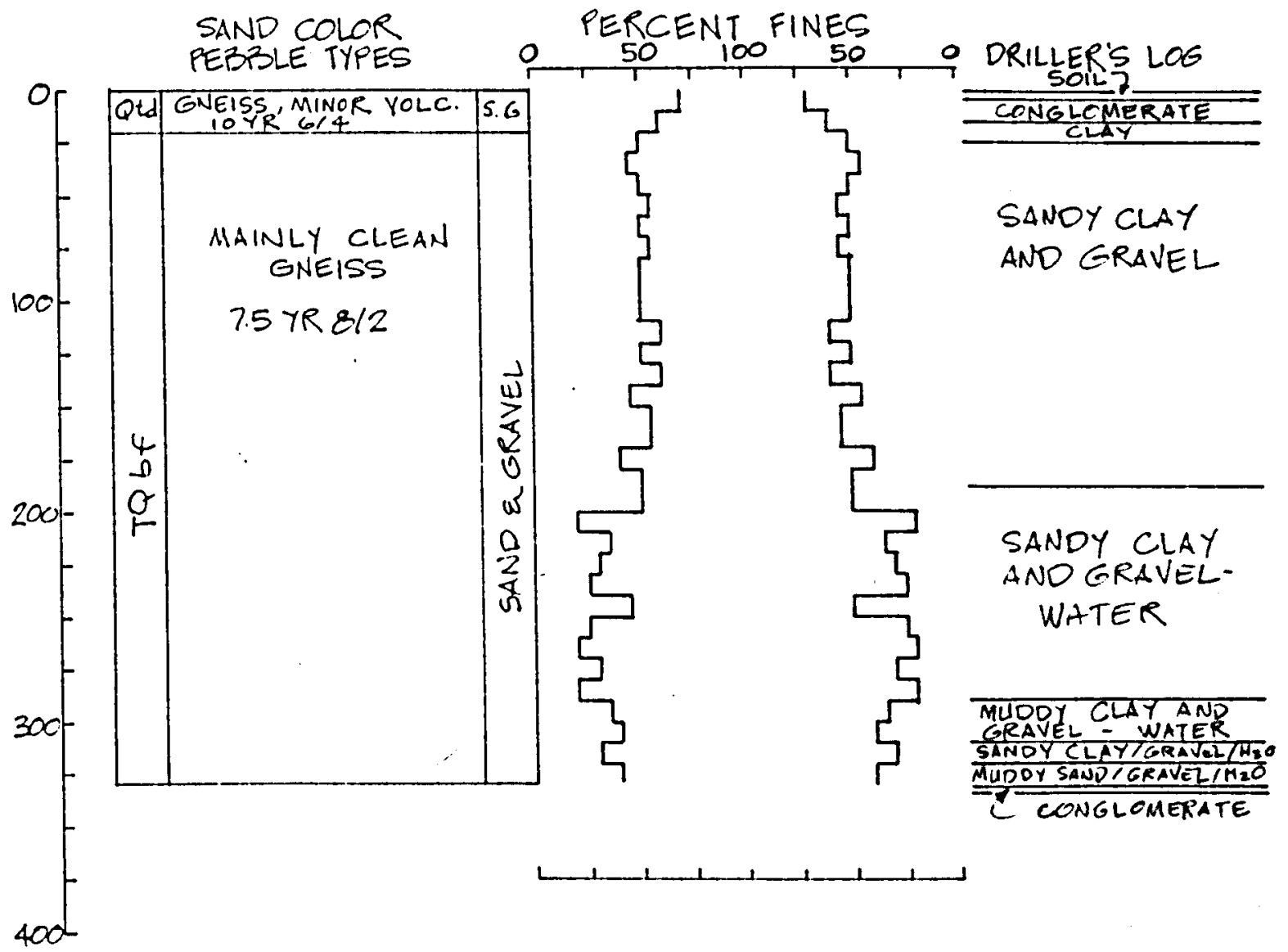

LCCATION

OWNER

CRILLING CO.

CRILLER

LAB. NO.

DATE DRILLED

WATER LEVEL

SURFACE EXIOSLIRE
$(D-14-15) 6 c c a a b$ ELDORADO

MCDANIEL GIBSON

2दET

NOV. 1965

185', NoV 1965 


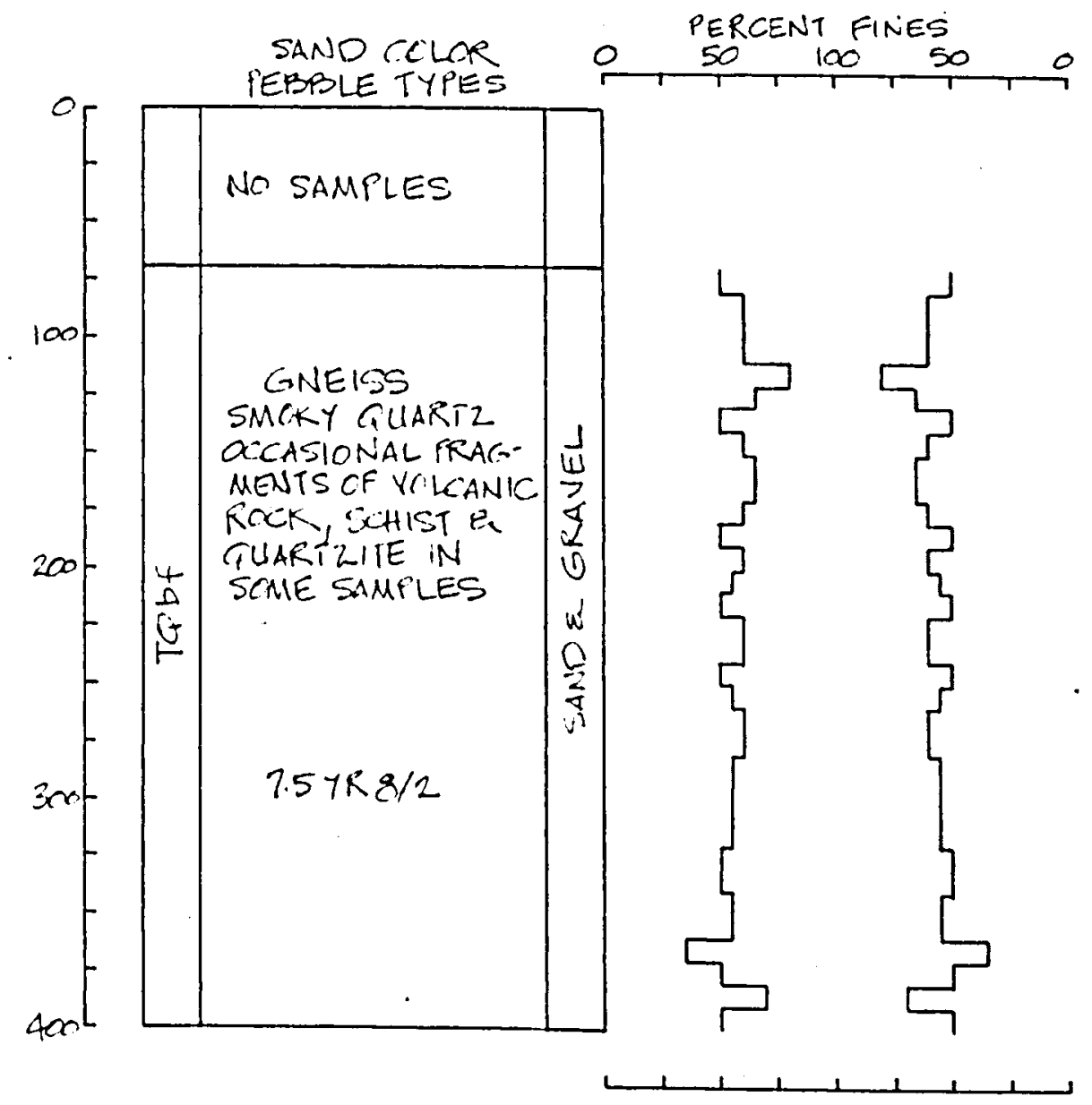

LOCATION

OWNER

$(0-14 \cdot 15) 6 \mathrm{ccd}$

ORILLING CO.

DRILLER

LAB.NO.

EL DKRADC.

ARIZ MAINT

DATE DRILLED

MAGNESS

2123

WATER LEVEL

APRIL, 1965

SURFACE EXPOSURE 


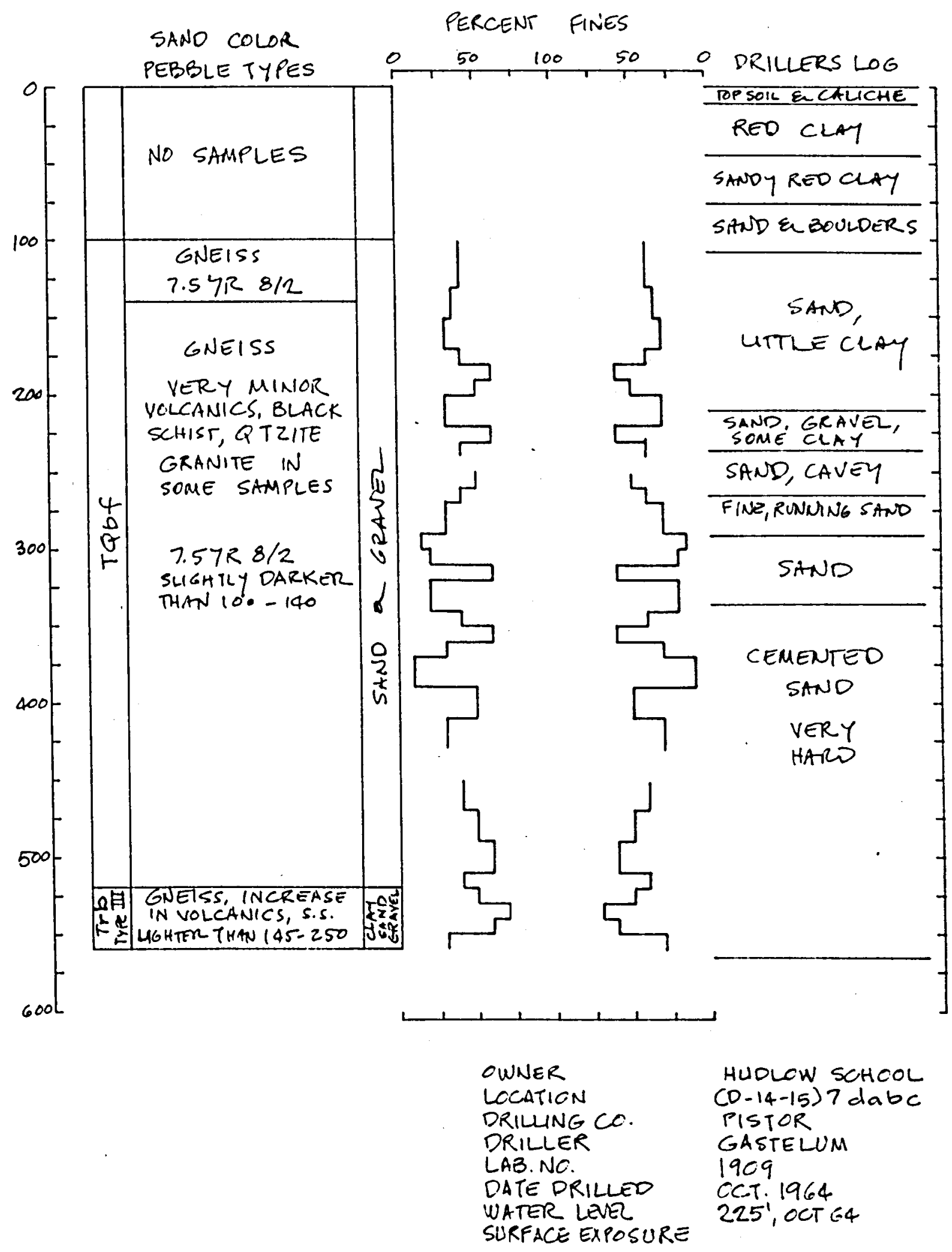




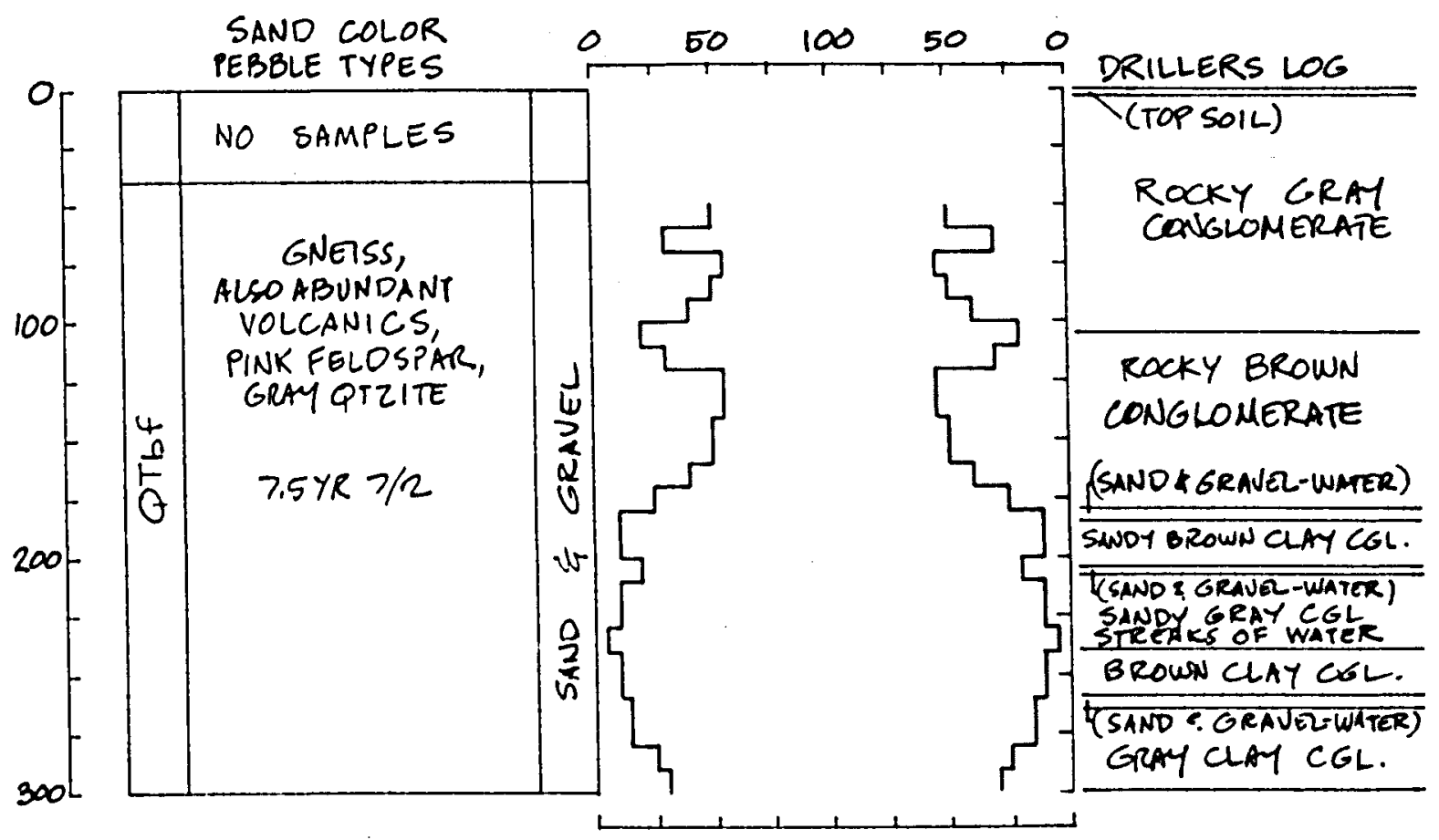

LOCATION

OWNER

DRILLINGCO.

DRILLER

LAB.NO.

DATE DRILLEO

WATER LEVEL

SURFACE EXPOSLRE
(D-14-15)12cbd GEGENHEIMER

FORSYTH

BANGHART

1764

JUNE, 1964

$181^{\prime}$ JUNE 64

Qbf 
PERCENT FINES

BY WEIGHT

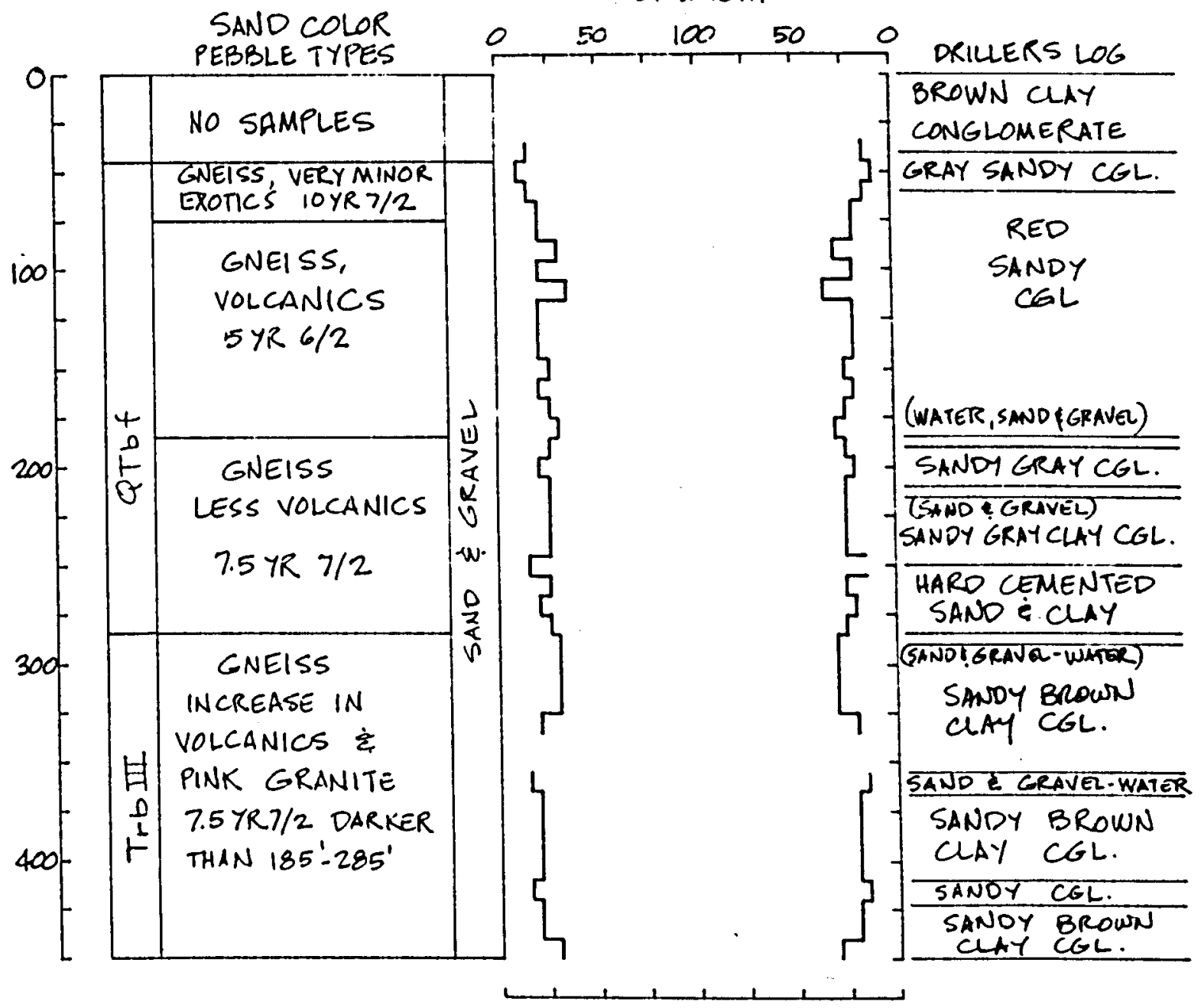

LOCATION

OWNER

DRILLING CO.

DRILLER

LAB. NO.

DATE DRILLED

WATER LEVEL

SLRFACE EXPOSURE
(D-14-15) 16 CICa

SPRING YALLEY

FORSYTH

BANGHART

1854

1960

$166^{\prime}$ APRIL, 1961 
236

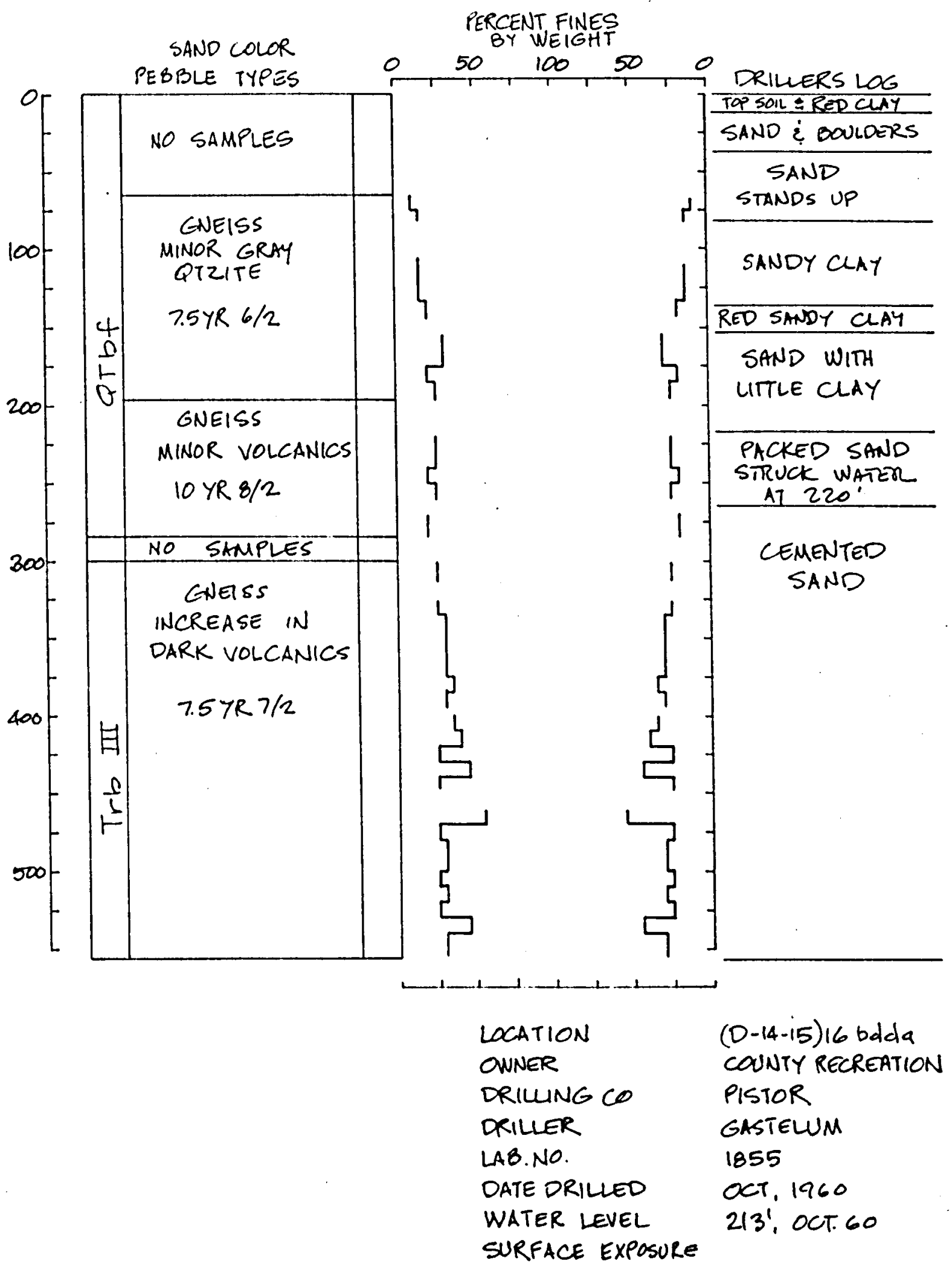




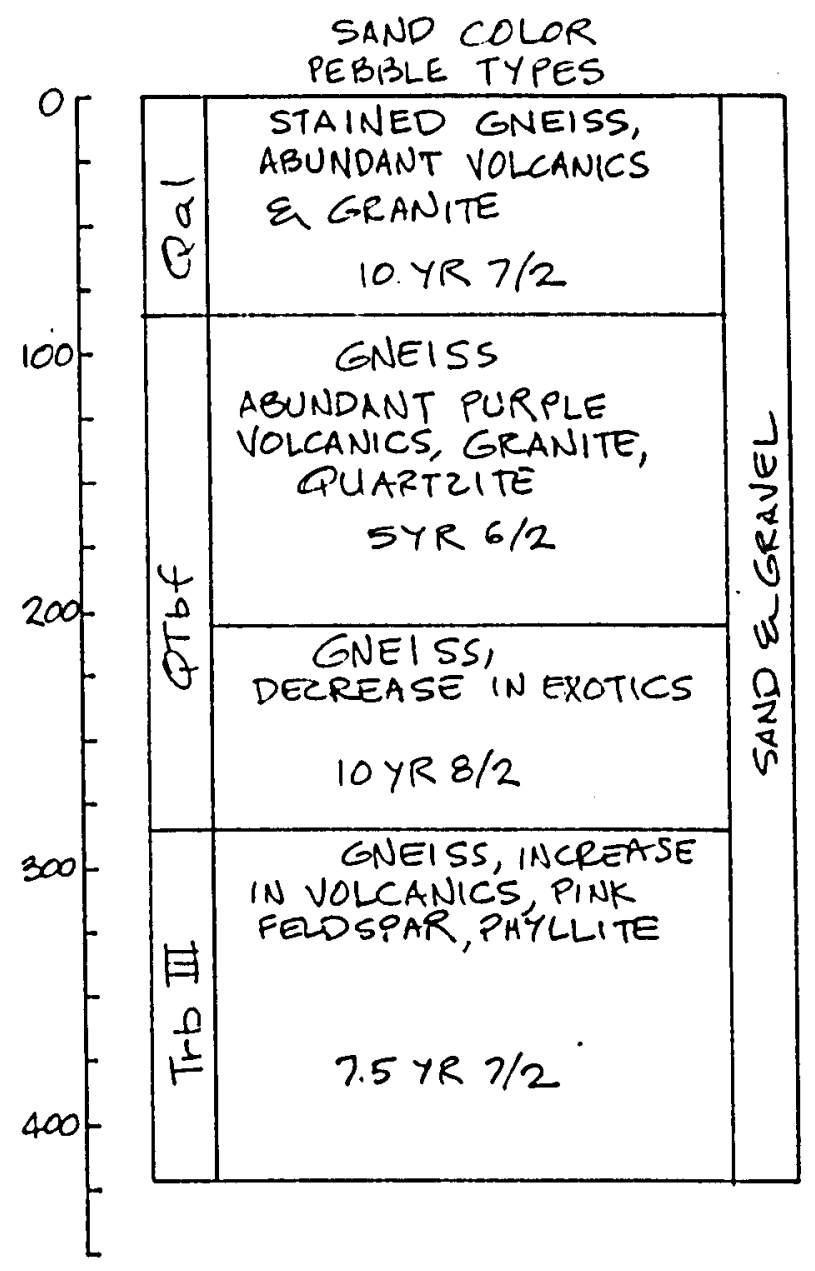

DRILLERS LOG
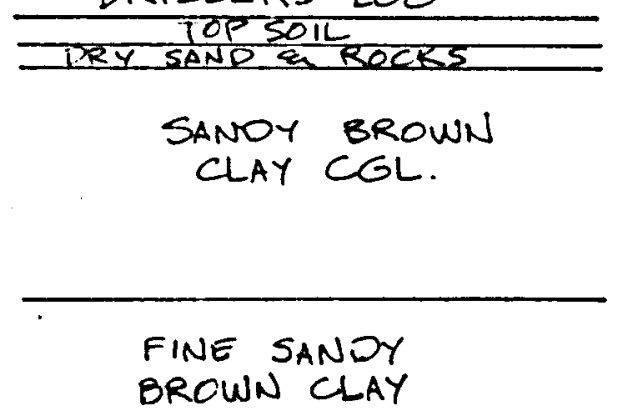
BROWN CLAY

$\frac{\text { (SANOEGRAVEL-WATER) }}{\text { (FINE SANDY BROWN CLAY) }}$ SANDY GRAY CLAY CoL.

SANDY BROWN CLAY CGL.

(SAND E GRANEL)?

SANOY BROWN CLAY CGL. (SANOE GRAVEL-WATER) SANDY GRAY Clay CGL.
LOCATION OWNER

DRILLING CO.

ORILLER

LAB.NO.

DATE DRILLED

WATER LEVEL

SURFACE EXPOSURE
(D-14-15)16 cacc LUSK

FORSYTH

BANGHART

1377

JAN 62

$197^{\prime}$ JAN' 62

Qal 


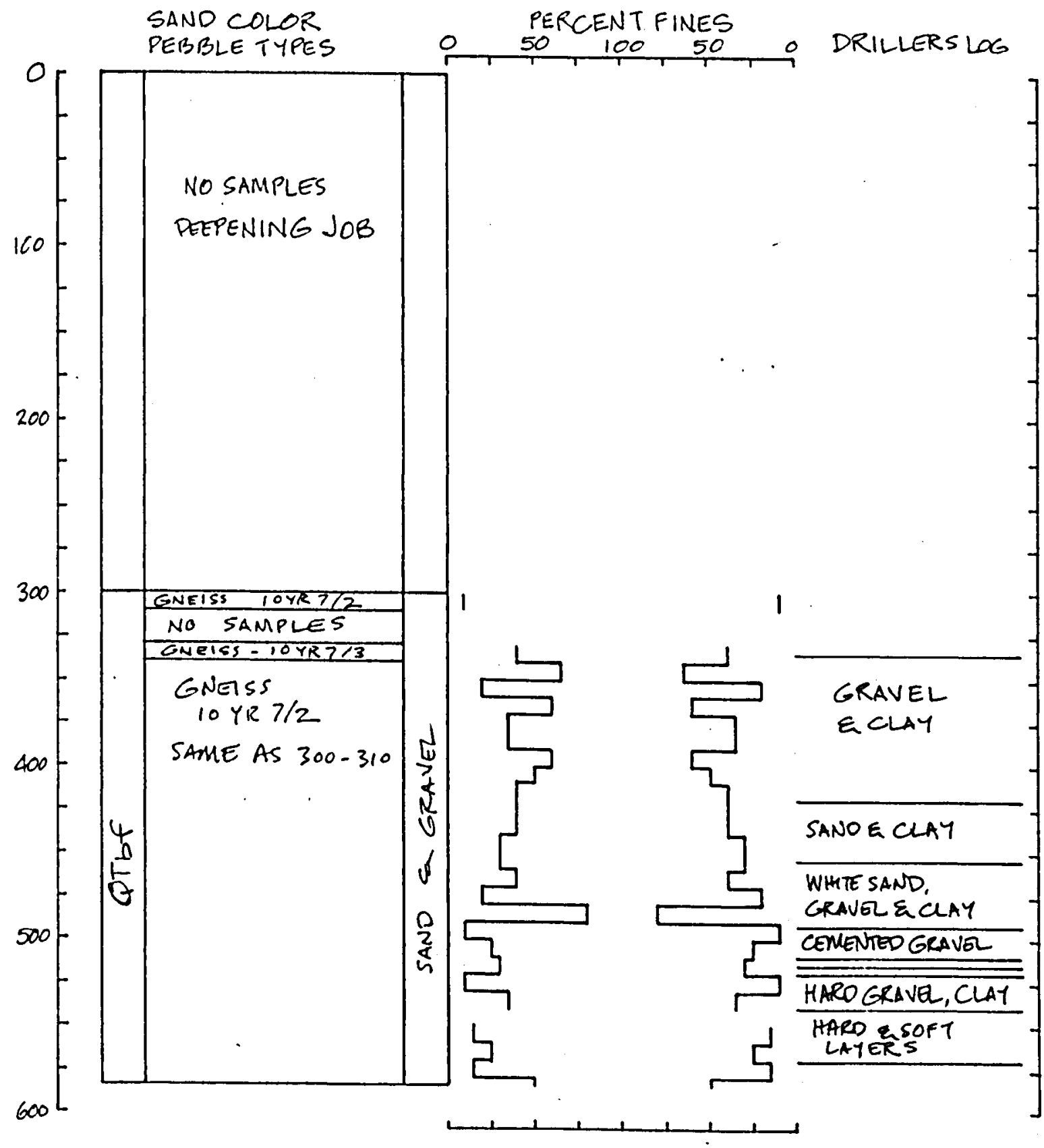

LOCATION

OWNER

ORLLUNG CO.

DRILLER

LAB. NO.

DATE DRILLED

WATER LEVEL

SURFACE EXPOSURE

$(D-14-15) 18 \mathrm{bac}$

TUCSON C.25

CITYRIG

LEATHERWOOD

2124

MAY, 65 


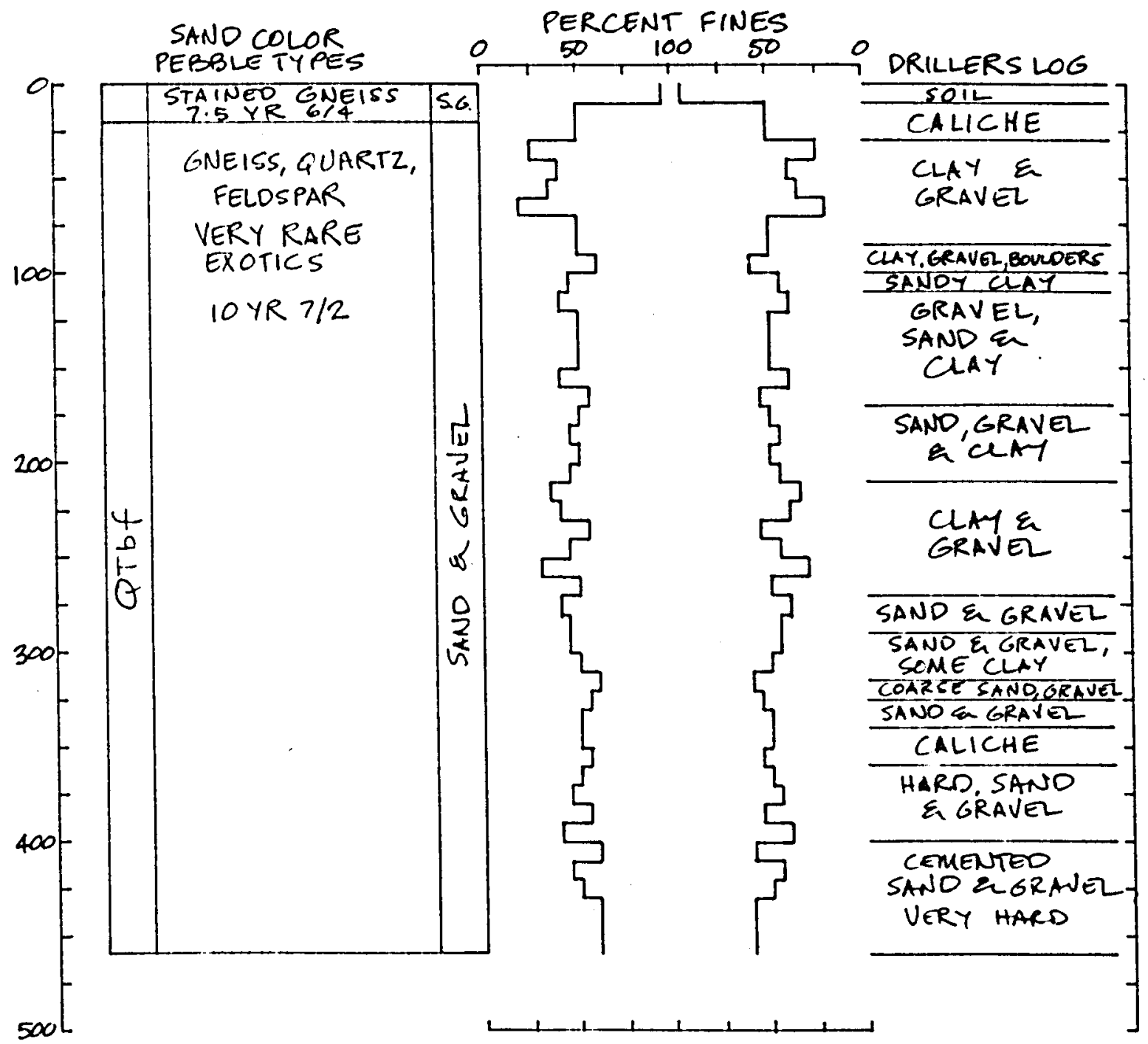

LOCATION OWNER

DRILLING CO.

DRILLER

LAB.NO.

DATE DRILLED

WATER LEVEL

SURFACE EXPOSURE
$(D-14-15) 18 c d a a$ TUCSON D-16 ARIZONA MAINT. POSEI 2193 SEPT 1964 $260^{\circ}$ 


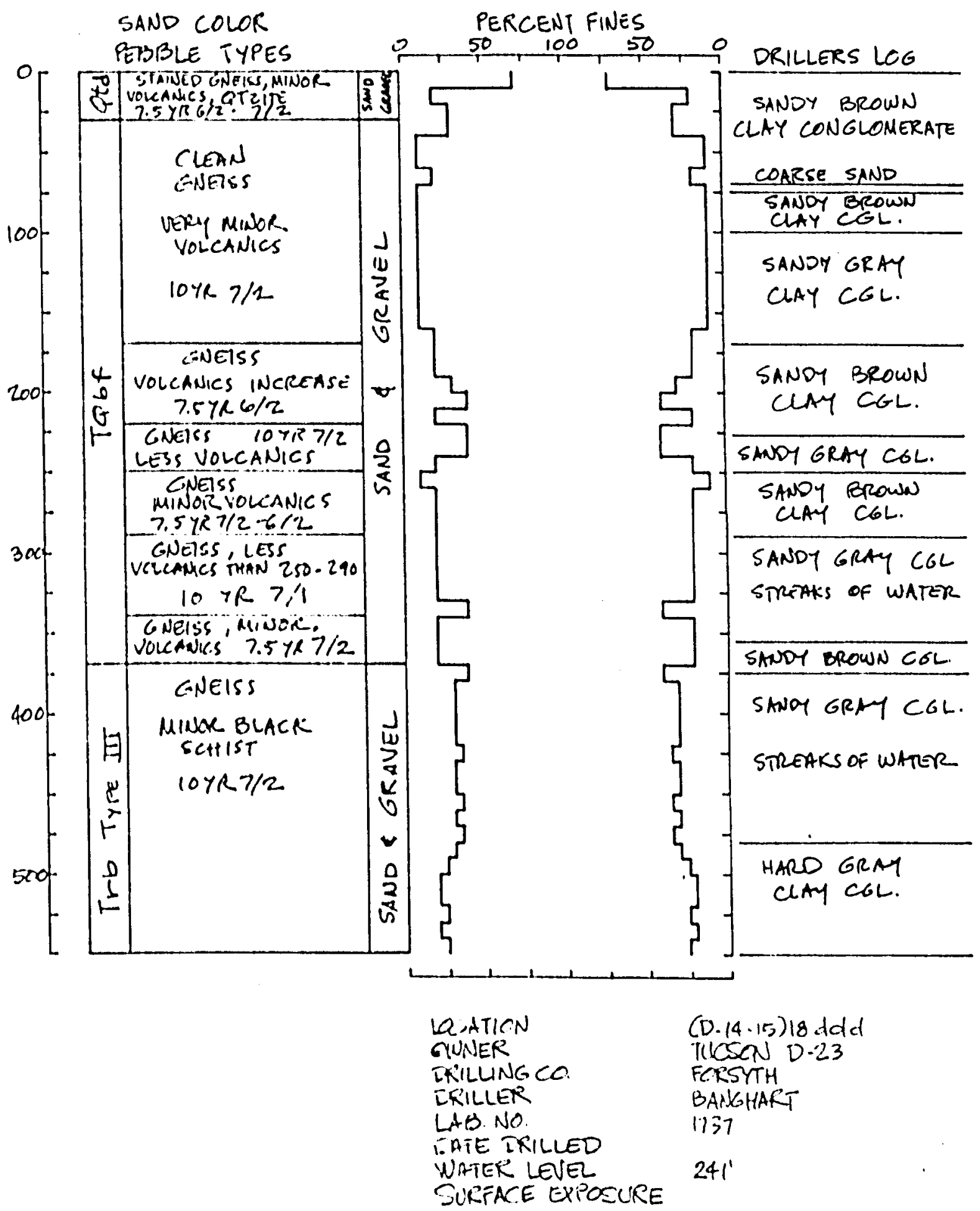




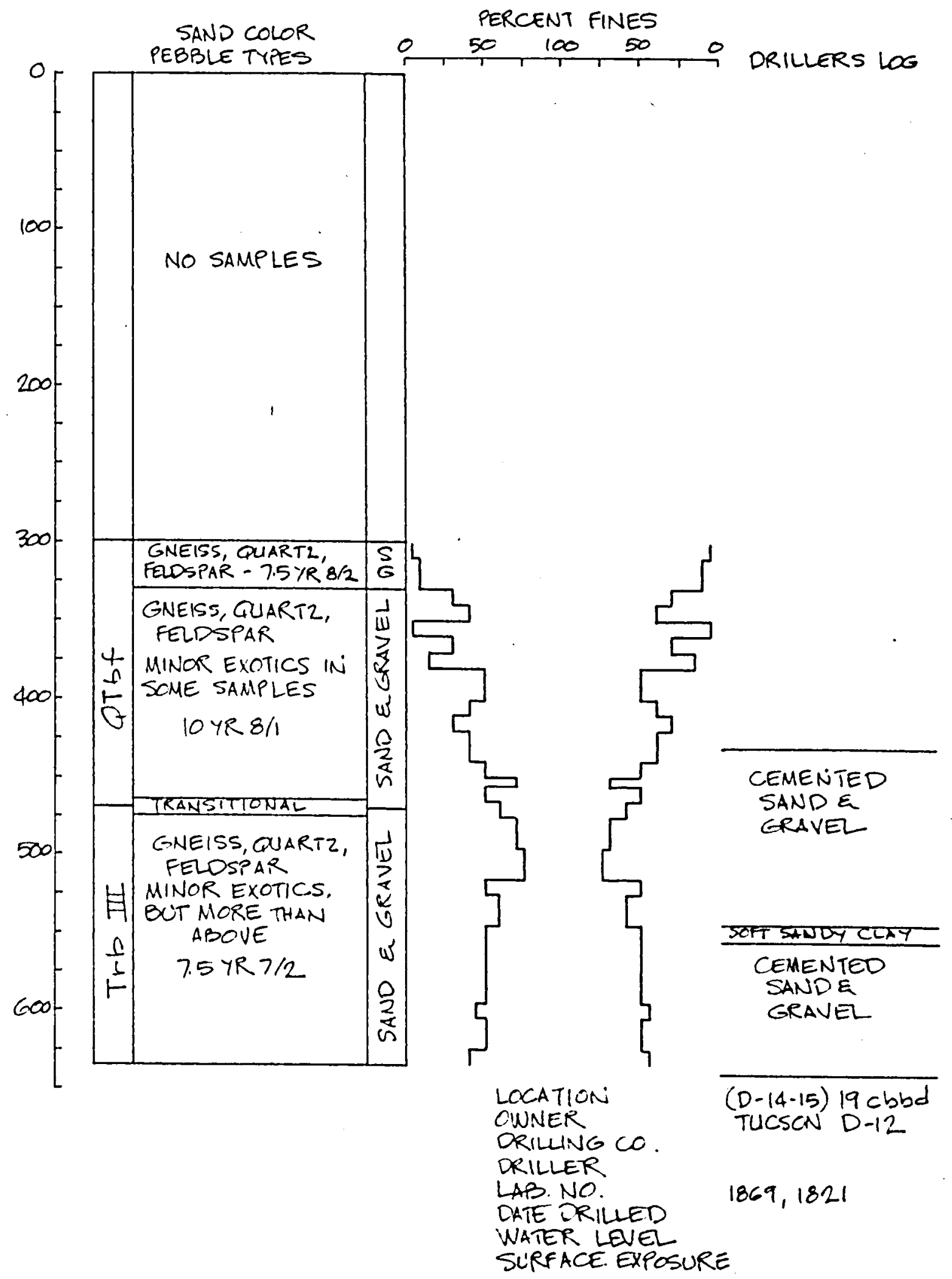




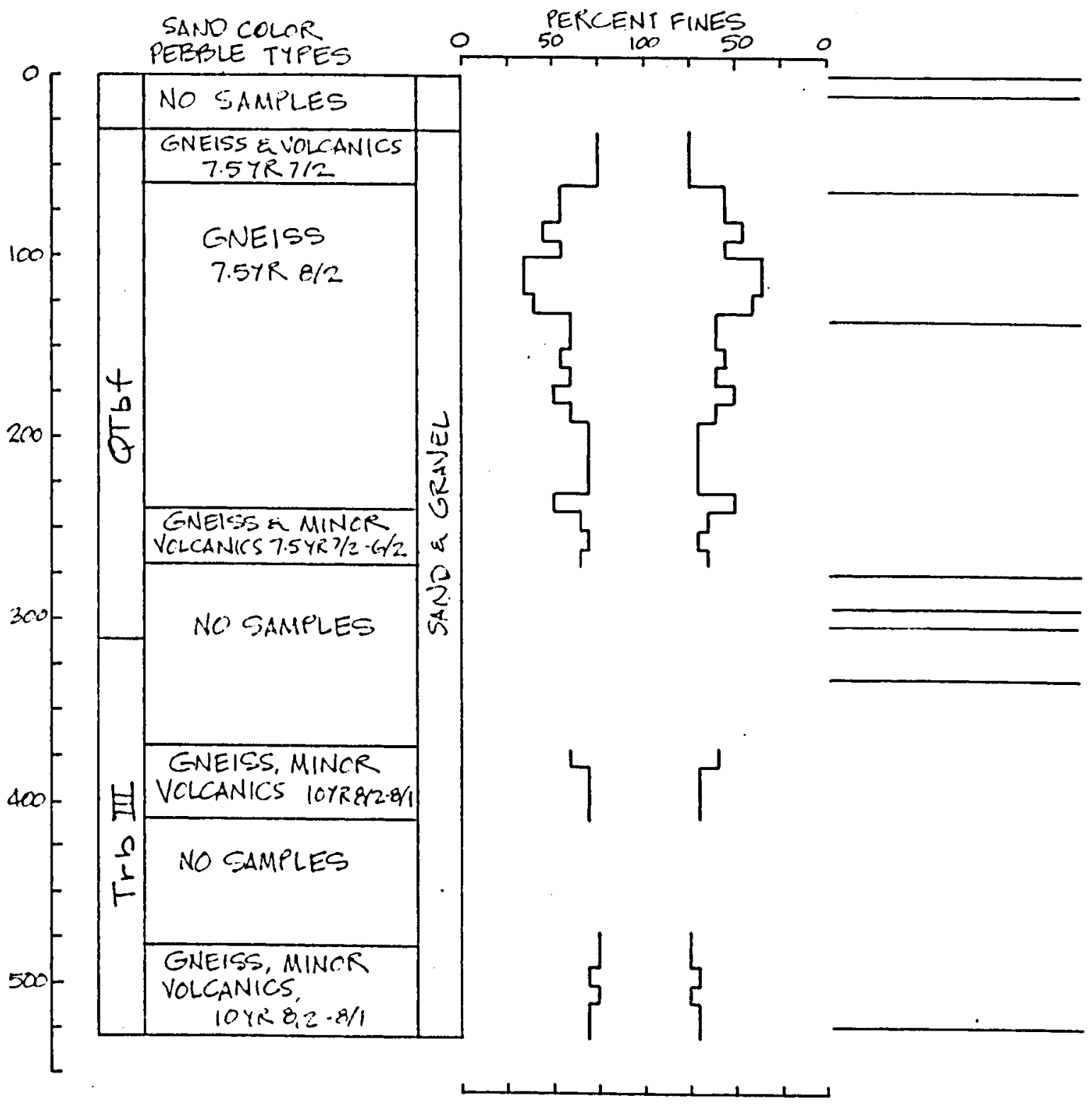

LOCATION

CUN:ER.

DRILLINGCO

ORILLER

LAB.NO.

OATE DRILLED

WATER LEVE.

SURFACE EXTOSLIRE.
$(D=14-15) 20 b b c$ MIANANAWATER CO. ARI2. MIAINT. MAGNESS 1856 


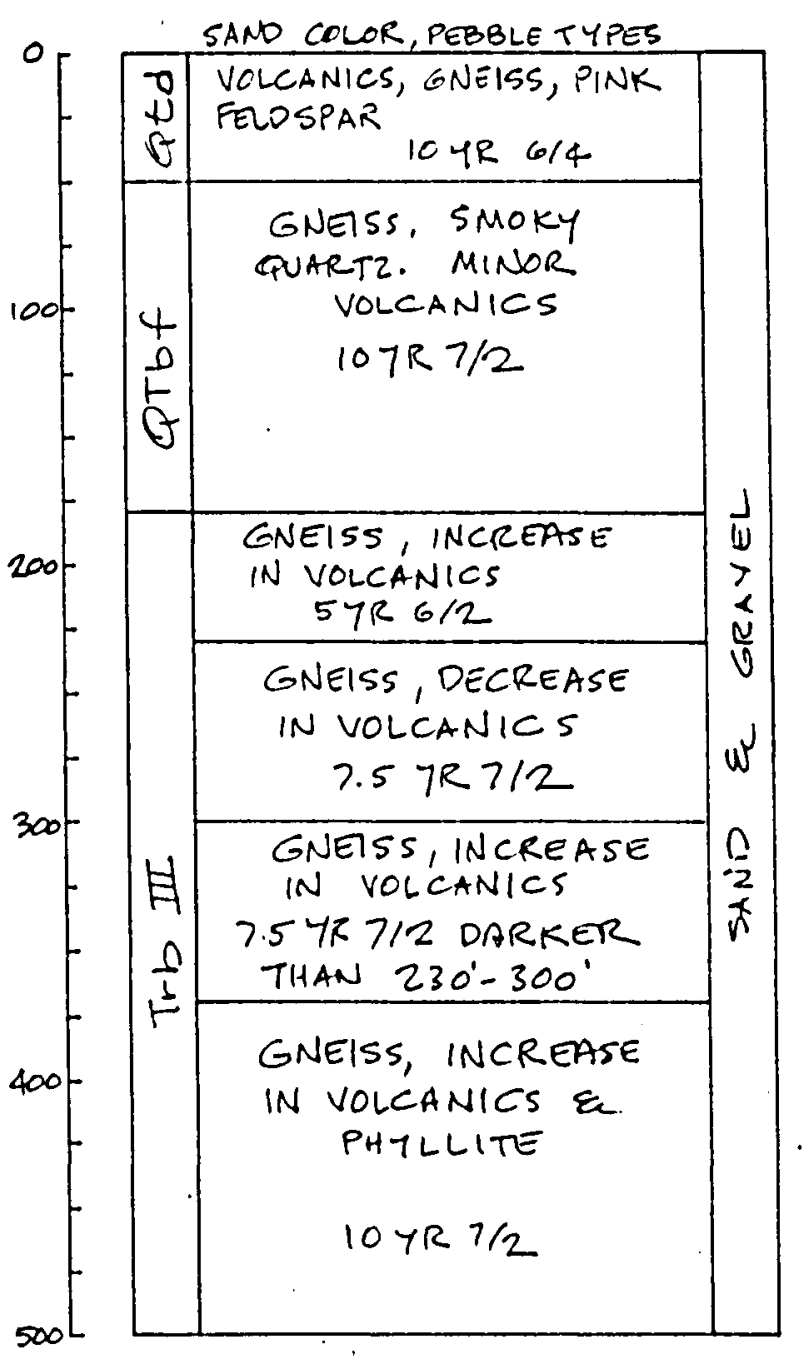

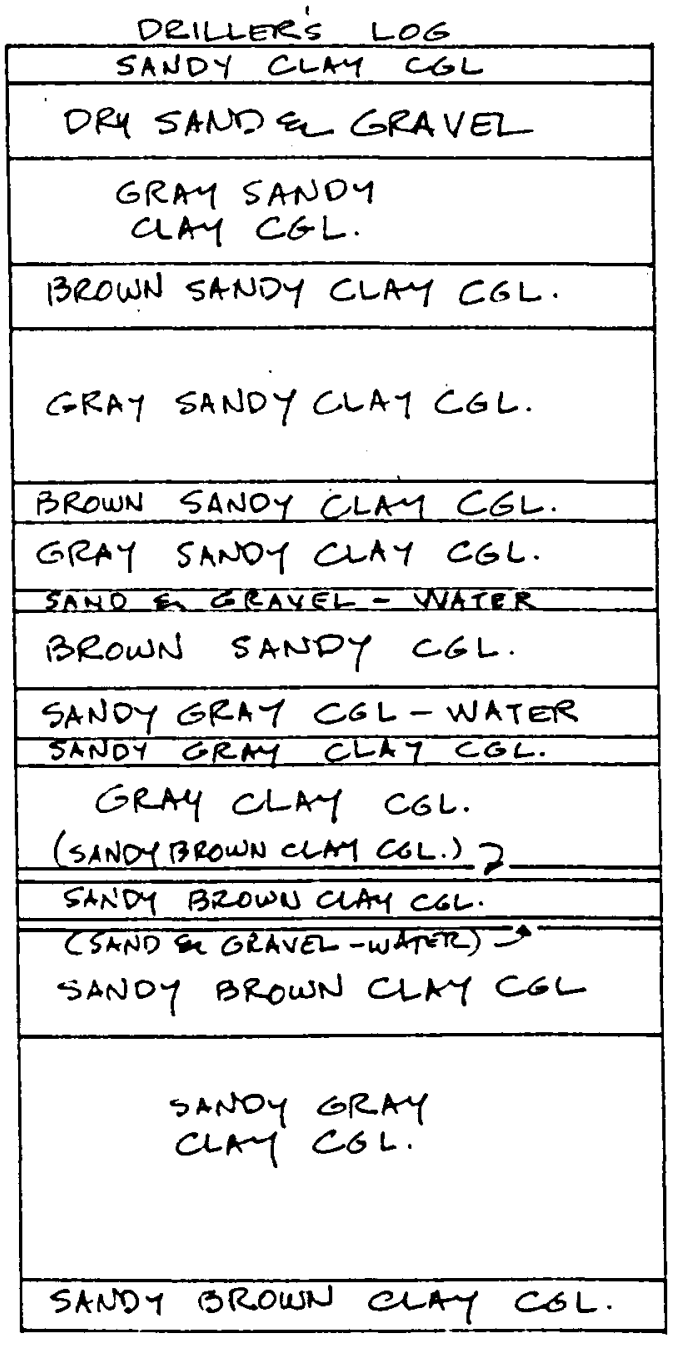

OWNER LOCATION

ORILLINGCO.

DRILLER

LAB. NO.

OATE DRIULT

WATER LE'EL

SURFACE EXPOSURE
ROLLING HIULS (O-14-15) 21 anc FORSYTH - LEMONS

1386 1961 

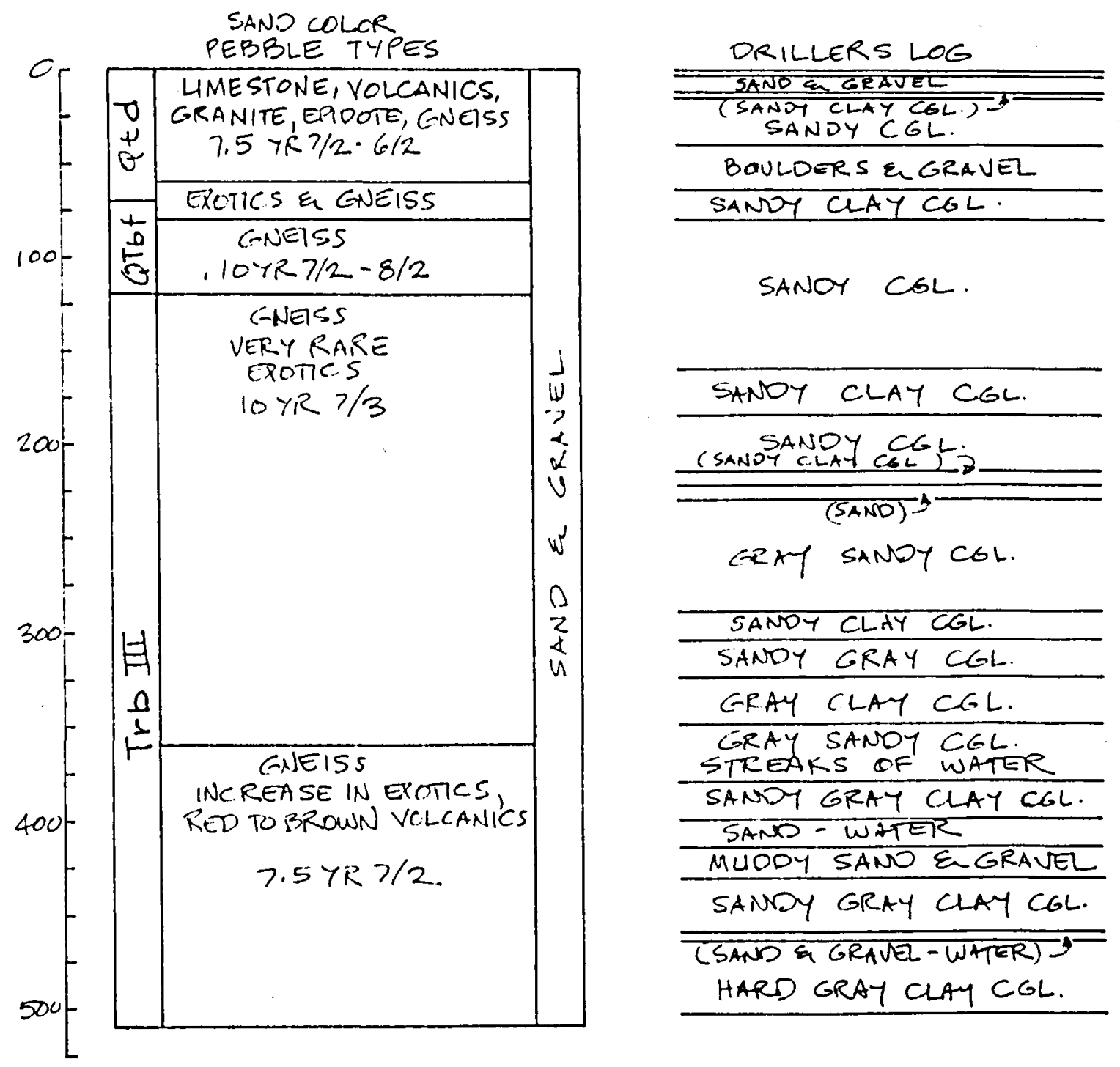

SANOT CGL.

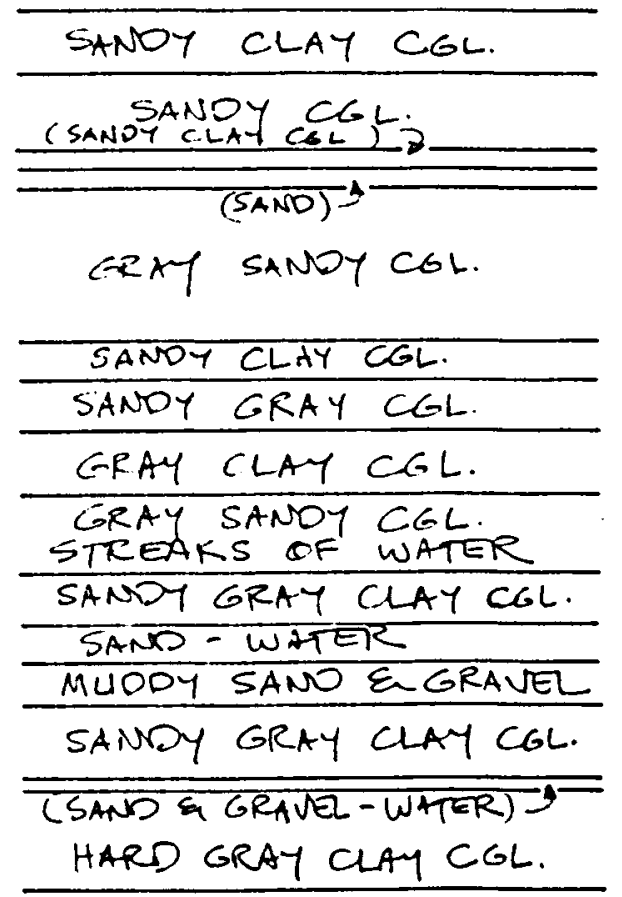

LOCATION

CWNER

DRILLINGCO.

RKILLER

LAB. NO.

Dateprilled

water level

surFace exposure
$(0-14-15) 22 \mathrm{cbb}$ ROLUNG HILLS 2 FORSYTH

LENONS

1378

OCT,1961

\section{etg}




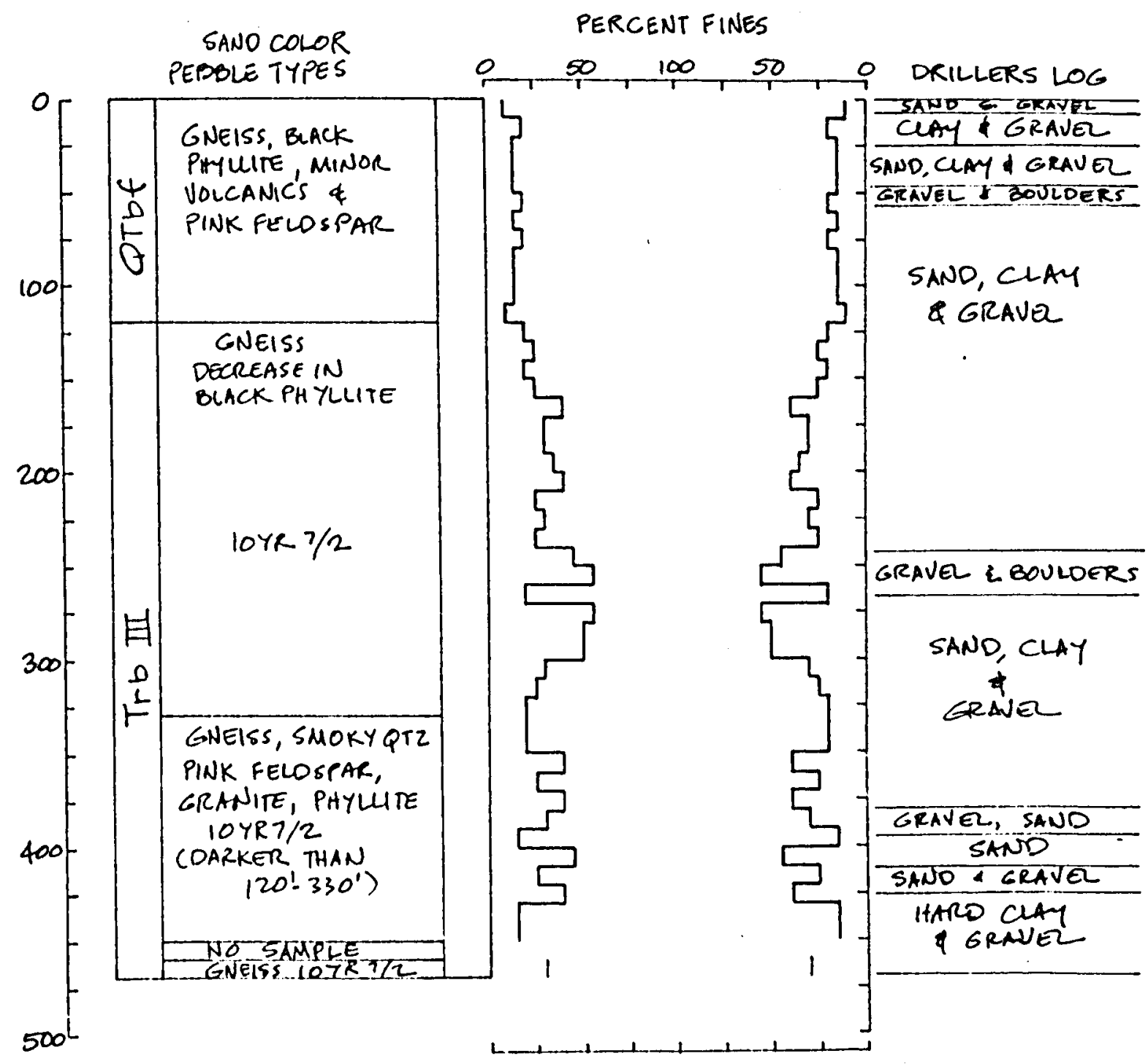

LOCATION.

OWNER

DRILLINGCO.

DRILLER

LAB.NO.

DATEDRIUED

water leval

SURFACE exposure
$(D-14-15) 25 \mathrm{ccb}$

RINCON RANCH

ARIZ. MAINT.

MAGNESS

1808

. MARCH, 1964

308', Mar, 64

Qbf 
246

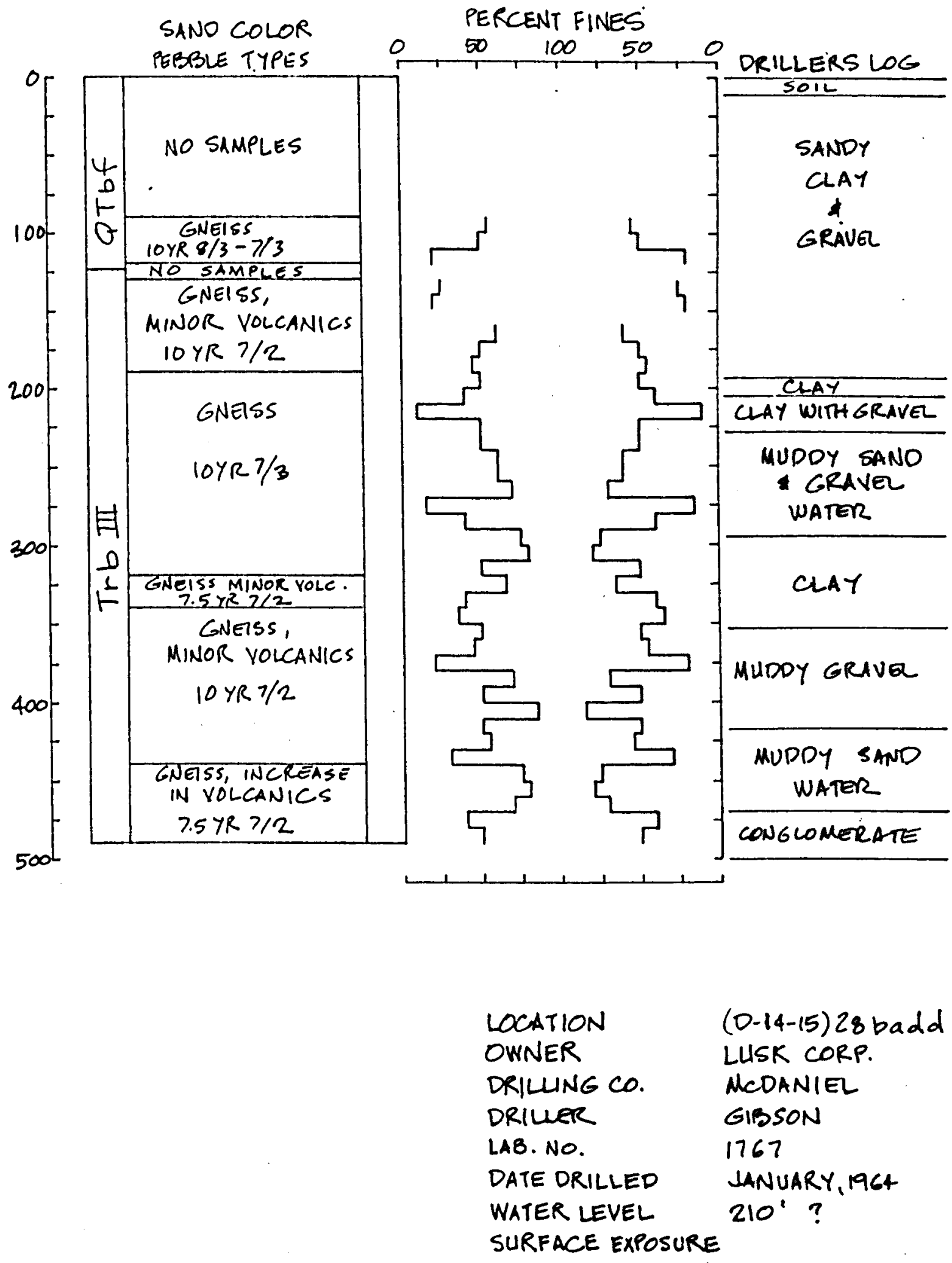




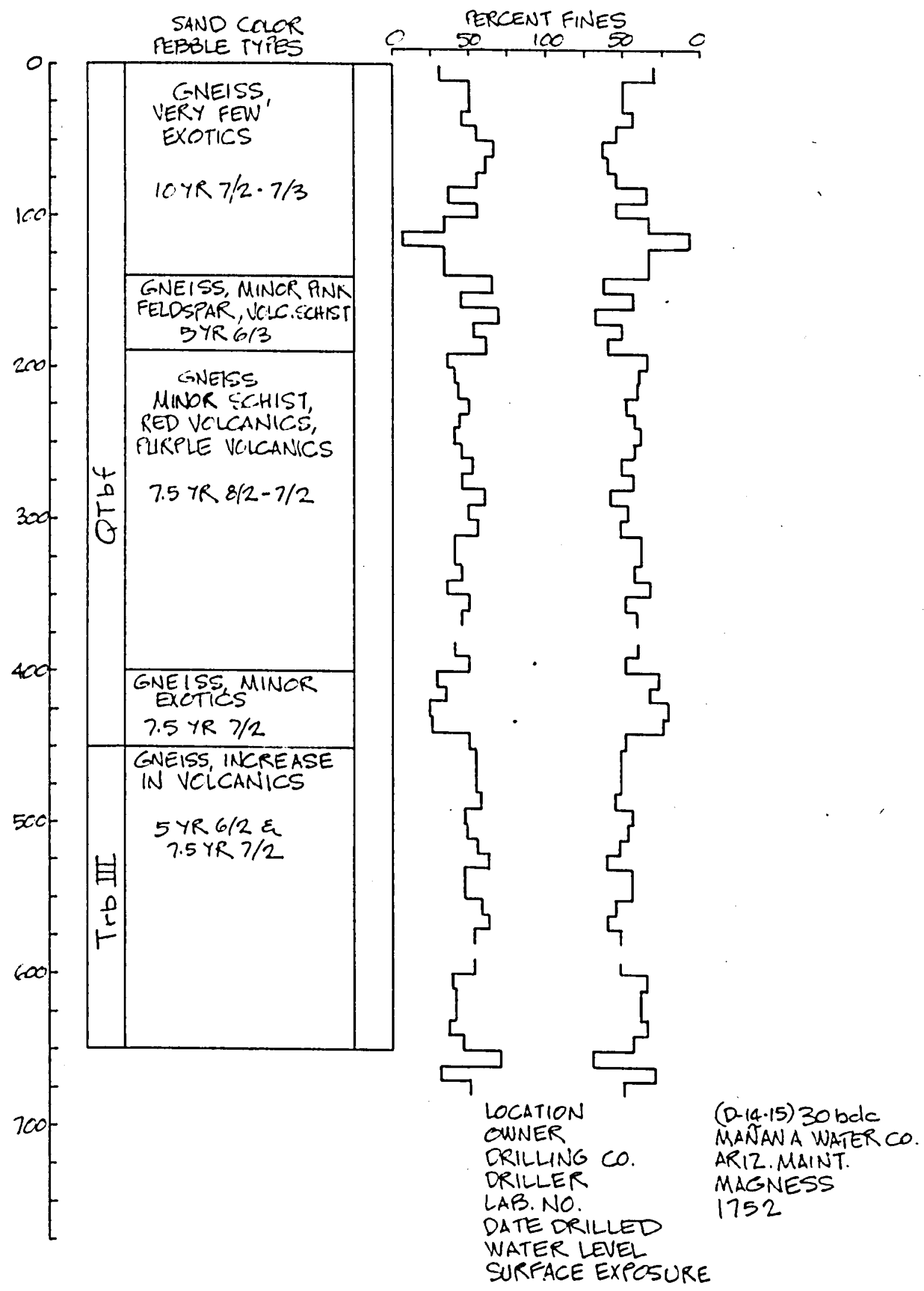




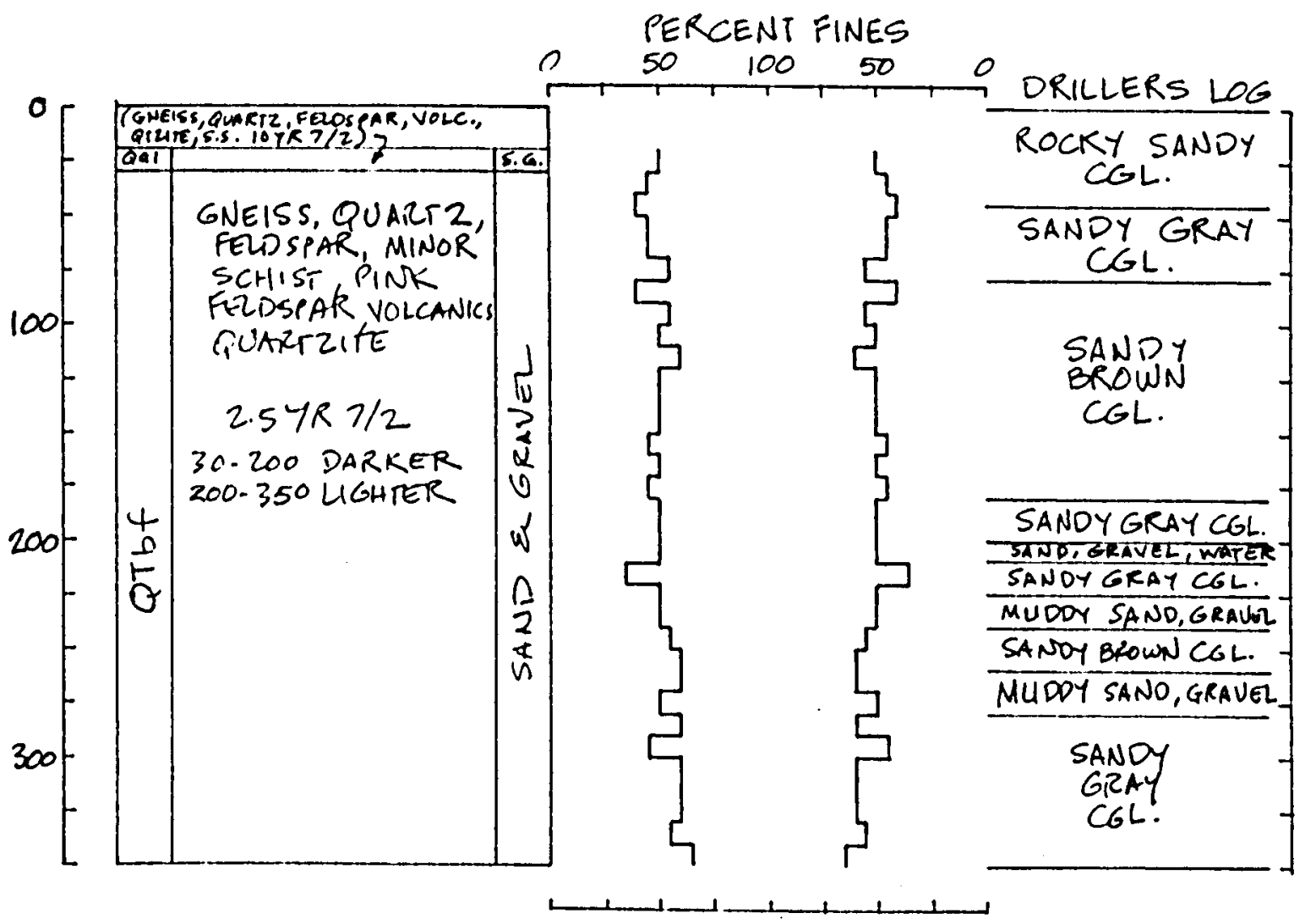

LOCATION OWNER

DRILLNG CO.

DRILLER

LAB.NO.

DATE DRILLED

WATER LEVEL

SURFALE EXPOSURE

$(0-14-15) 35 \mathrm{cad}$ GARRIGAN

FORSYTH

BANGHART

2298

AUG. 1965

$200^{\circ}$ AU 6.65

Qal 


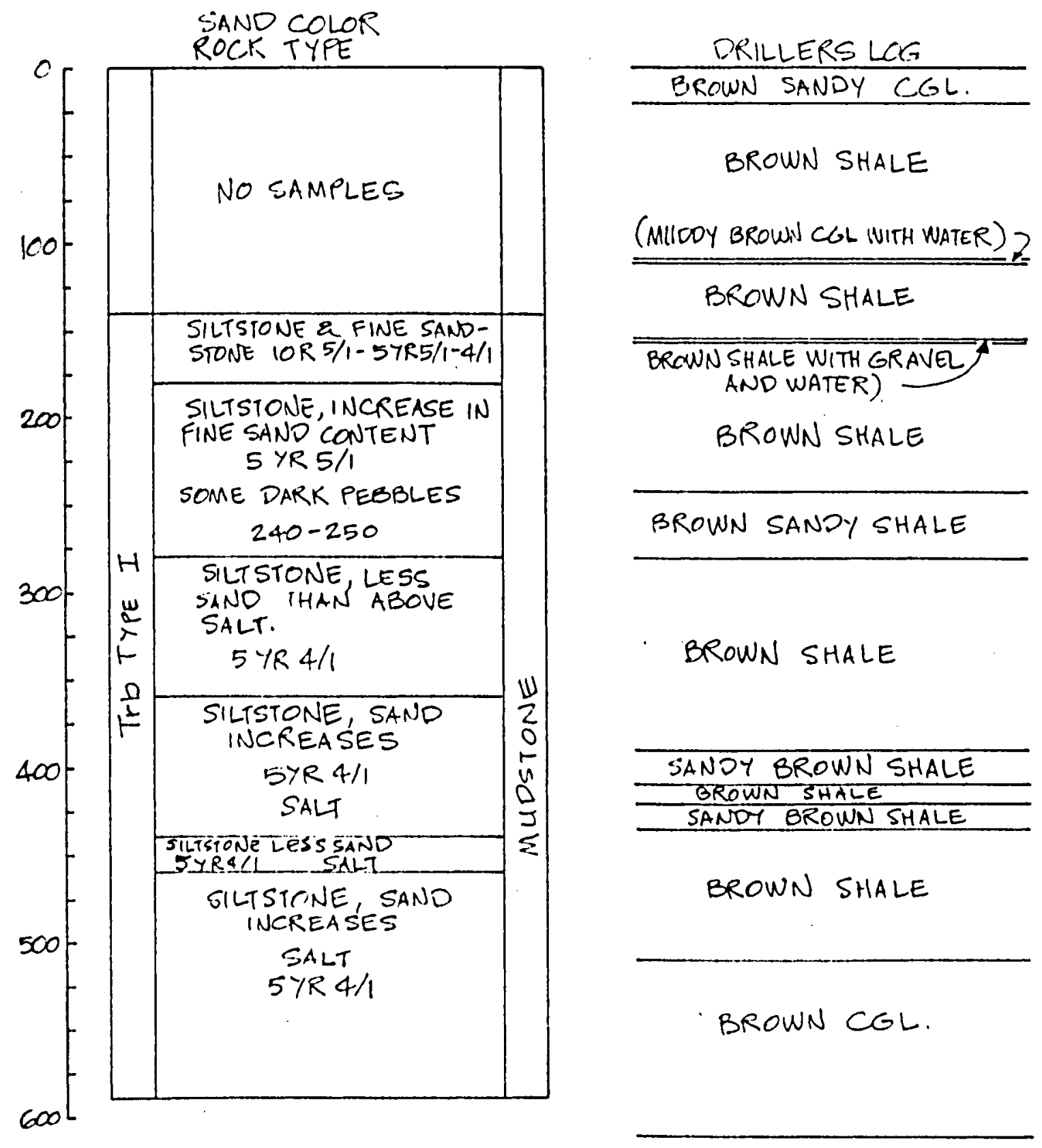

LOCATION

OWNER

DRILLING CO.

DRILLER

LAB. NO.

DATE DRILLED

WATER LEVEL

SURFACE EXPOSURE
$(D-14-16) 4$ beld DEVRIES

MCDANIEL

HEALDT

1862

$55^{\prime} F E B \quad 61$

Qal 


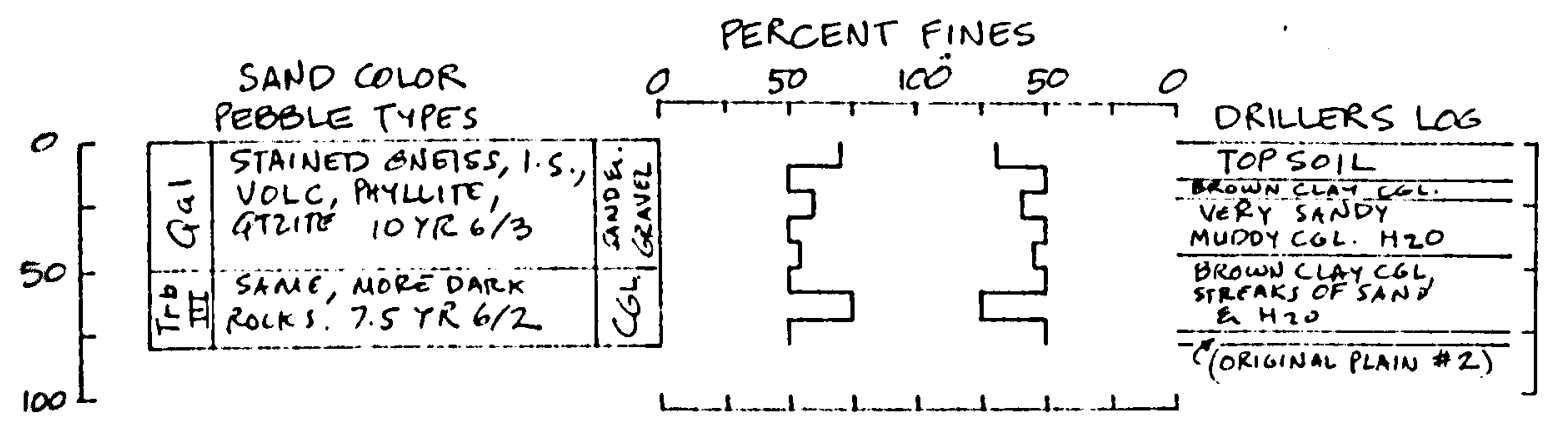

LOCATION

CWNER

RILLINGCO.

DRILLER

LAB́ NO.

DATE DRILLED

WATER LEVEL

SIRFACE EXPOSURE
$(0-14-16) 5 c d b$

PRAY

FORSYTH

BANGHART

1778

JAN, 1964

24 JSNG4

Qal 


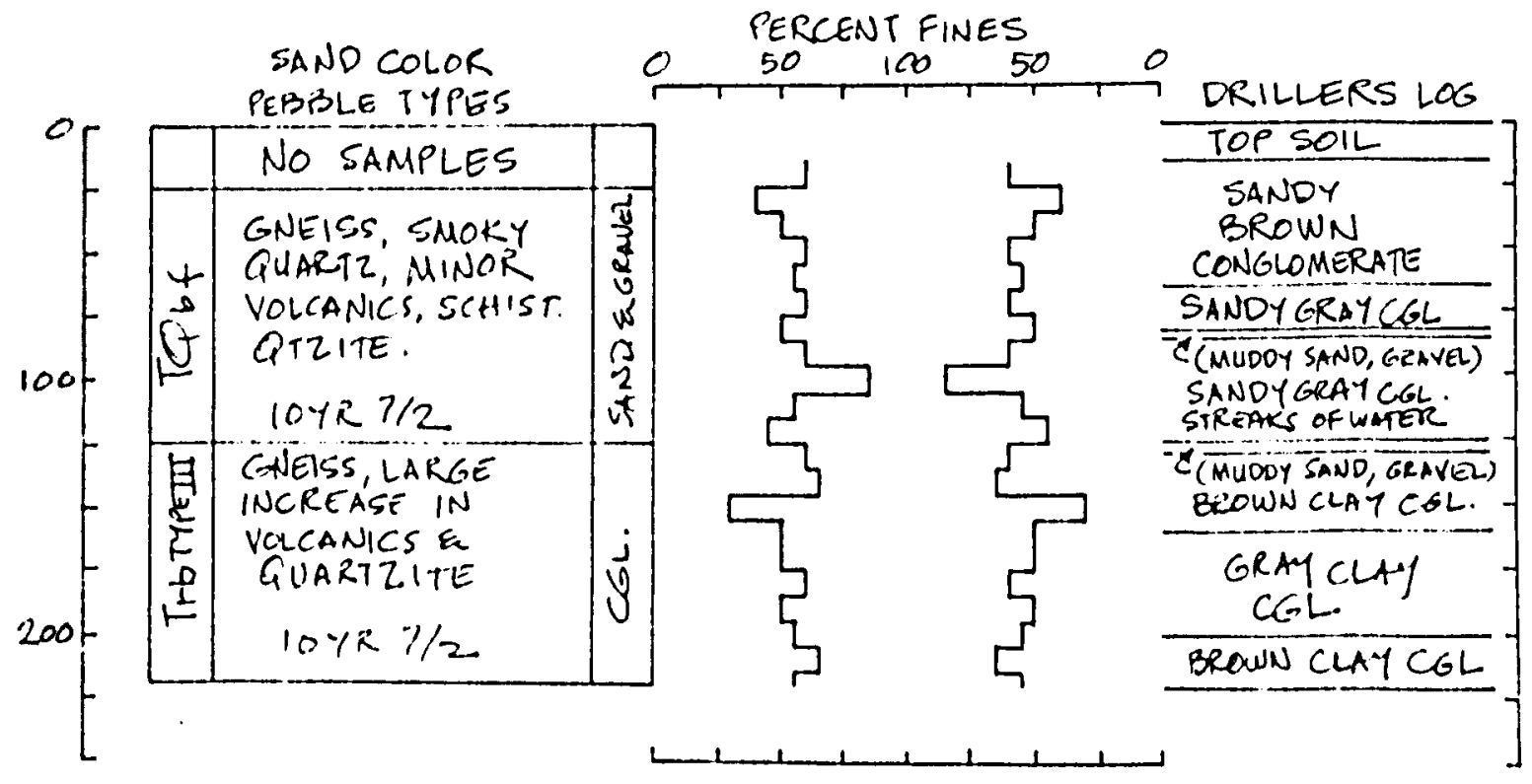

LOCATION

CWNER

DRILUNE CO.

DRILLER

LAB. NO.

DATE DRILLED

WATER LEVEL

SURFACE EXPOSURE
$(D-14-16) 6$ cdaa

PRESENT

FORSYTH

BANGHART

2141

JUNE 1965

$83^{\prime}$ LUUNE 65

atoftg. 
SAND CELOR

\begin{tabular}{|c|c|c|c|}
\hline 0 & $\underset{v}{\tilde{G}}$ & $\begin{array}{c}\text { STAINET GNEISS, } \\
\text { MINOR EXOTICSS } \\
\text { IC YE \& } 3\end{array}$ & $\begin{array}{l}\text { SANO } \\
\text { E } \\
\text { CXNELL }\end{array}$ \\
\hline 50 & th+ & $\begin{array}{r}\text { NO PEBBLES } \\
5 Y \text { Y } 4 / 1\end{array}$ & $\begin{array}{l}\text { MUPD- } \\
\text { SIRNE }\end{array}$ \\
\hline
\end{tabular}

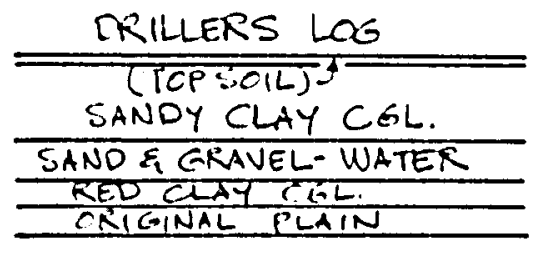

LOCATION

OWNER

CRILLNA CO.

IRILLER

LAB. NO.

$(0.14 .16) 9 a 90$

GREEN

FOKSYTH

DATE DRILLED

1860

WATER LEVEL

FEB, 1961

SLRFACE EXPCSURE QAI 
253

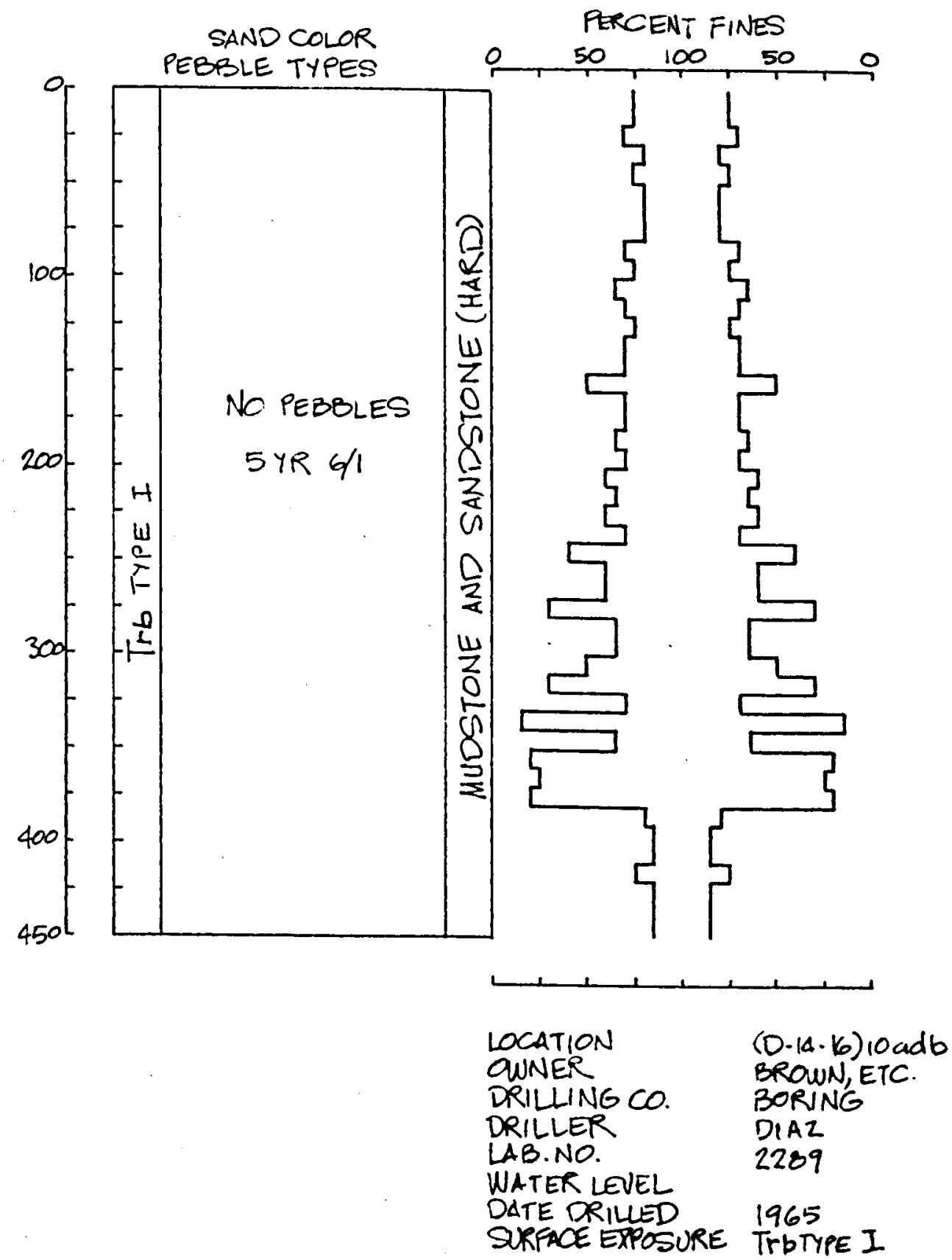




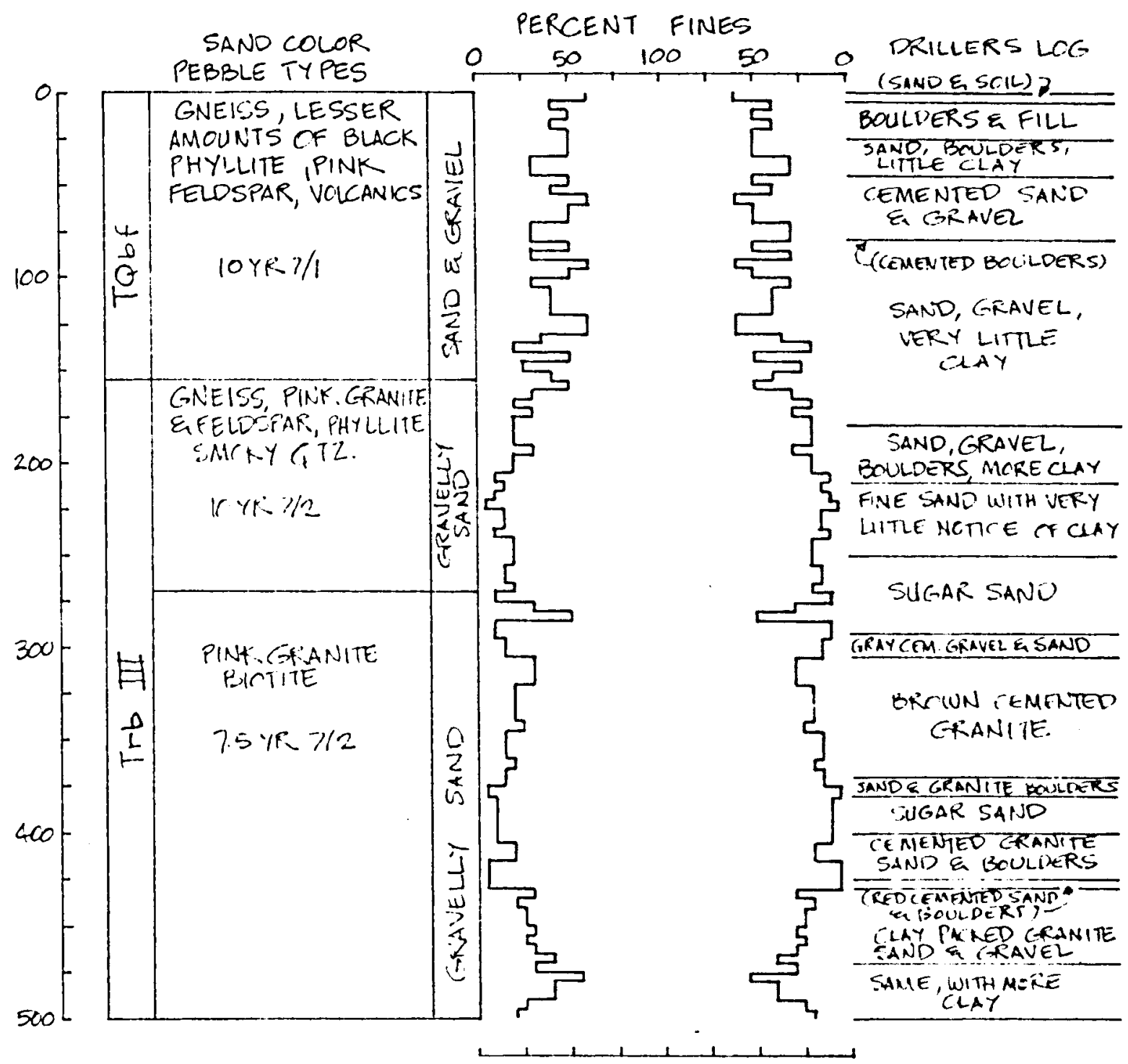

LCOATION

CUNER

ORILLINGCO.

IRILLER

LAB. NO.

TATE SRILLED

WATER LEVEL

SURFACE EXPOSURE
$(0-14-16) 31$ bbc

U.S. PARK SERVICE

BORING

BARINE

1792

MARCH 1964

$233^{\prime}$ MARCH 1964

Coftg 


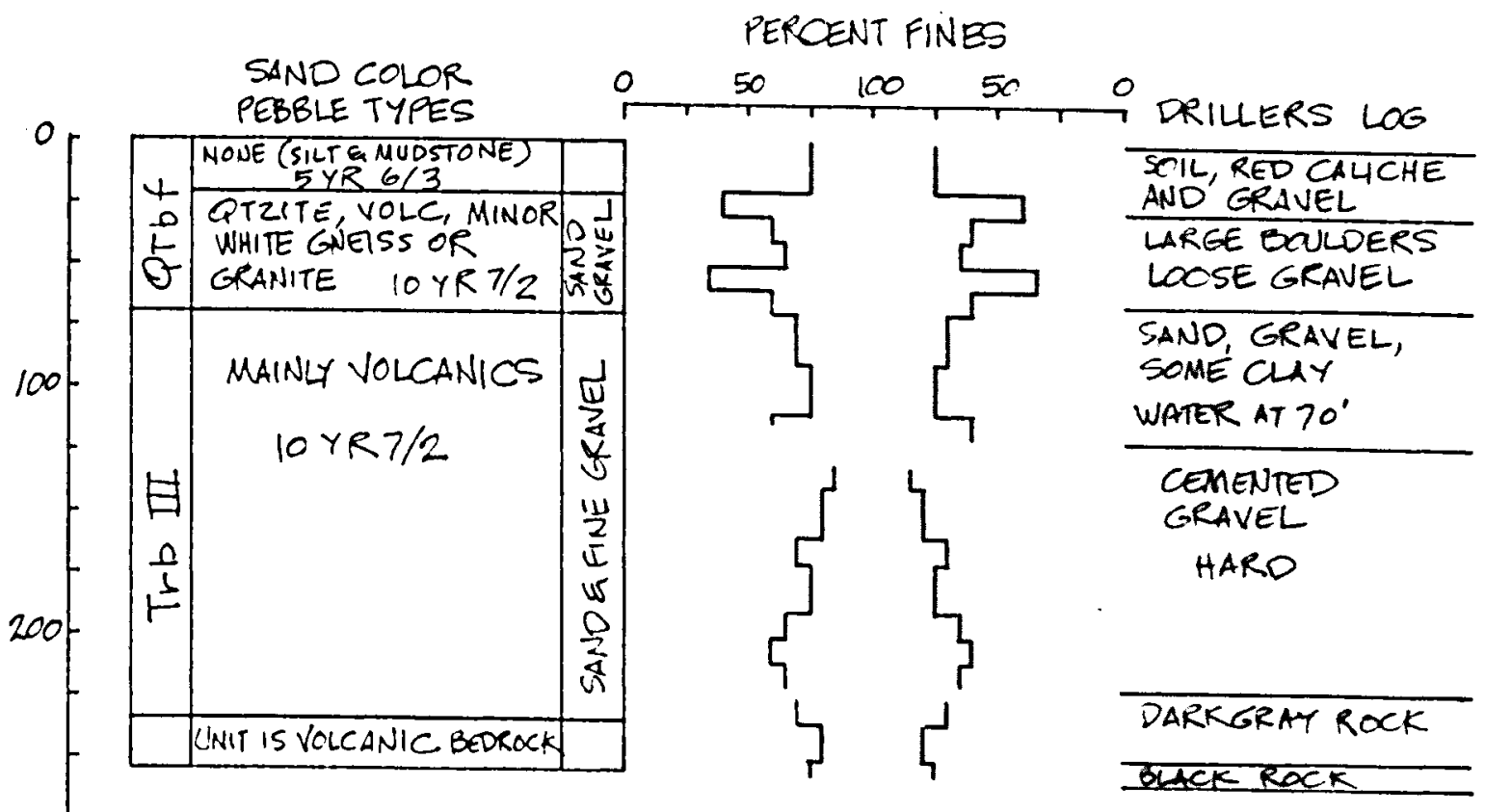

3000

LCCATION

CWNER

DRILLING CO.

DRILLER

LAB. NO.

DATE DRILLEO

WATER LEVEL

SURFACE EXPOSURE
$(0-15-13) 11$ baa

TUCSCN SS 22

PISTCR

1807

MAY, 1962

65 MAY, 62 


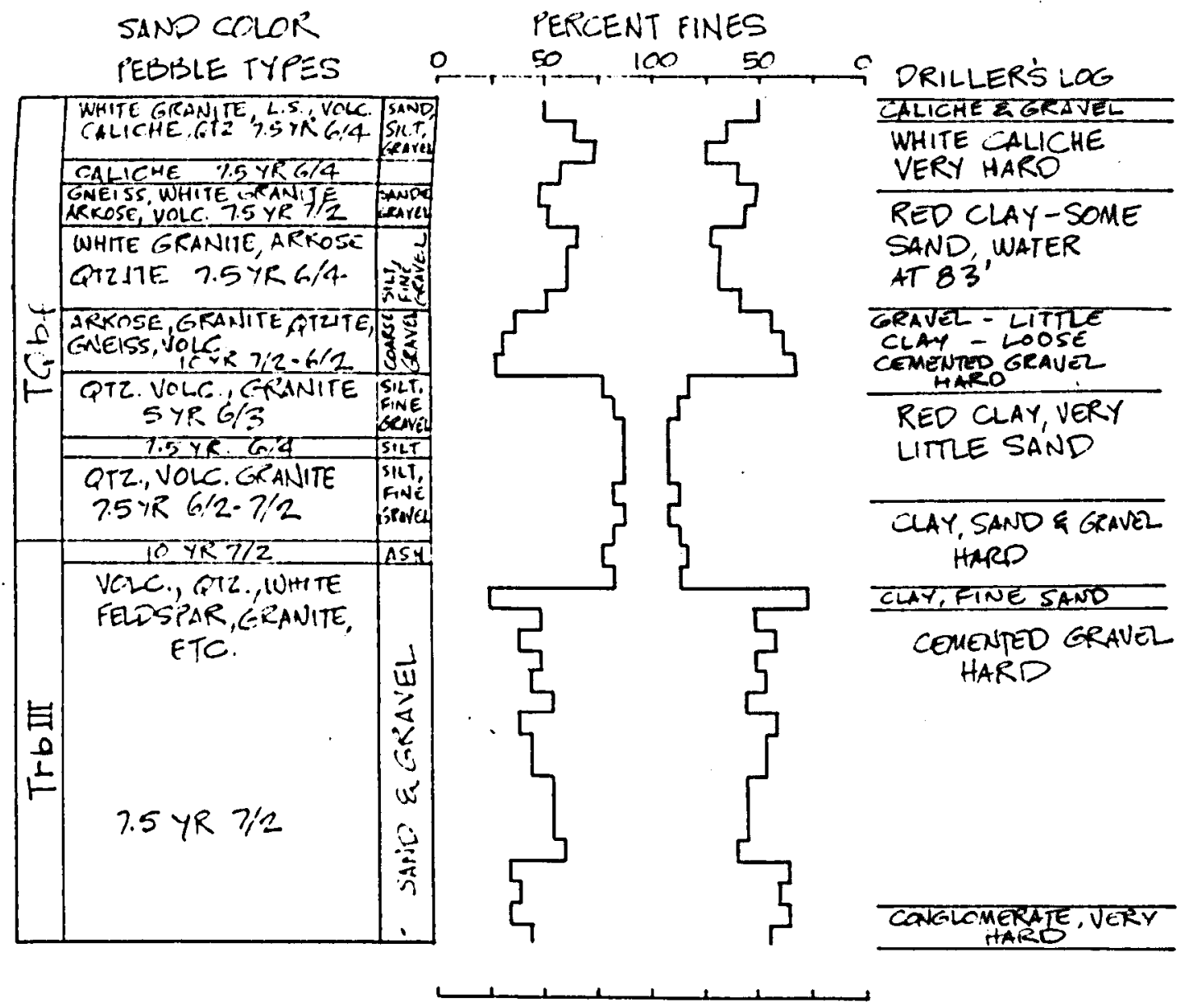

LOCATION

CWNER

DRILLINECO.

DRILLER

LAB. NC.

DATE CRILLED

WATER LEVEL

SIRFACE EXPCOURE
$(0.15-13) 13$ abc

TUCSON C-62

PISTOR

THOMPSON

2303

JANi, 1966 


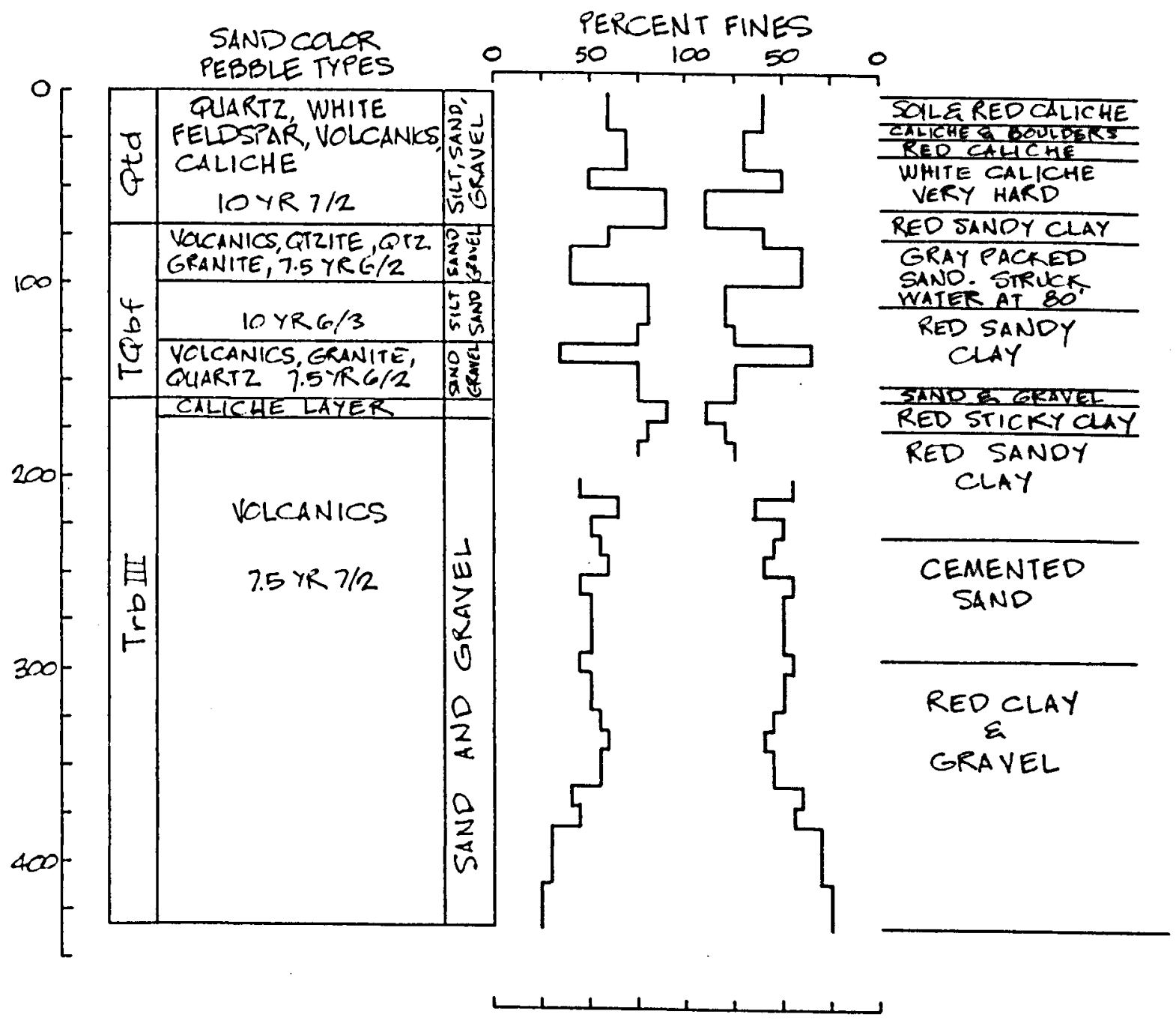

LOCATION

OWNER

PRILLING CO.

DRILLER

LAB NO.

DATE CRILLEO

WATER LEVEL

SURFACE EXPOSURE

$(0-15-13) 13 \mathrm{cba}$

CiTy C-66

PISTOR

1739

JULY 1961

68' JULY' 61 


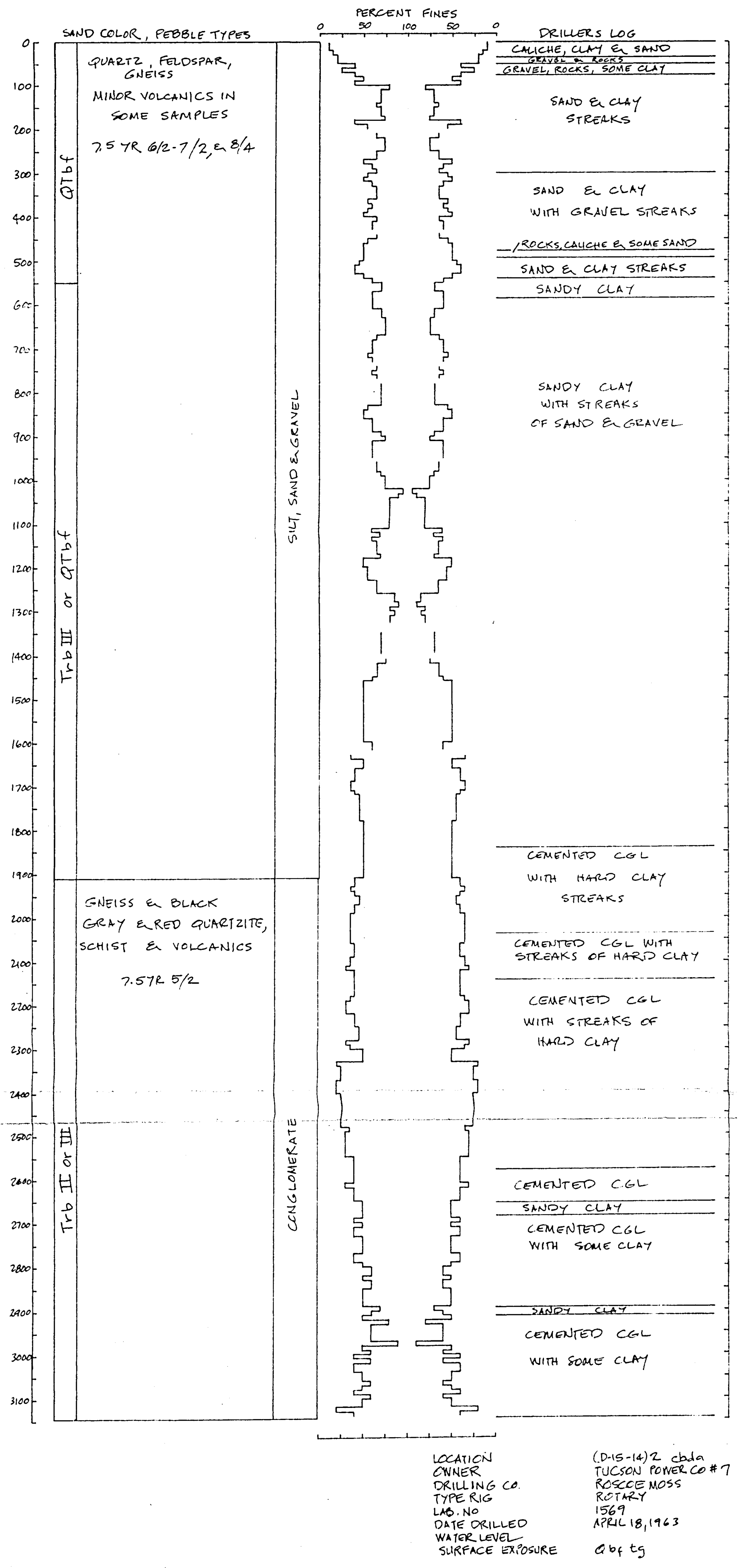




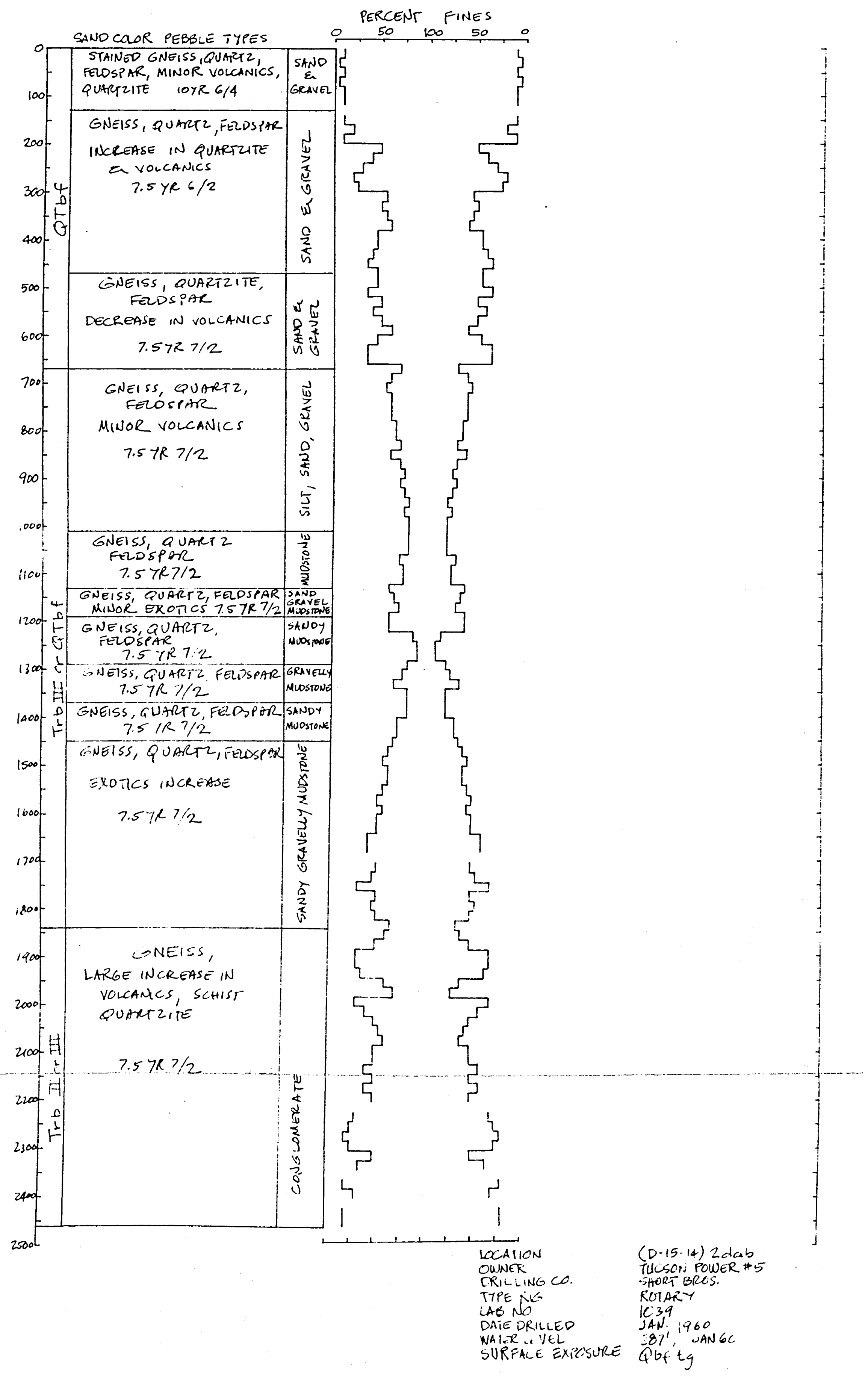




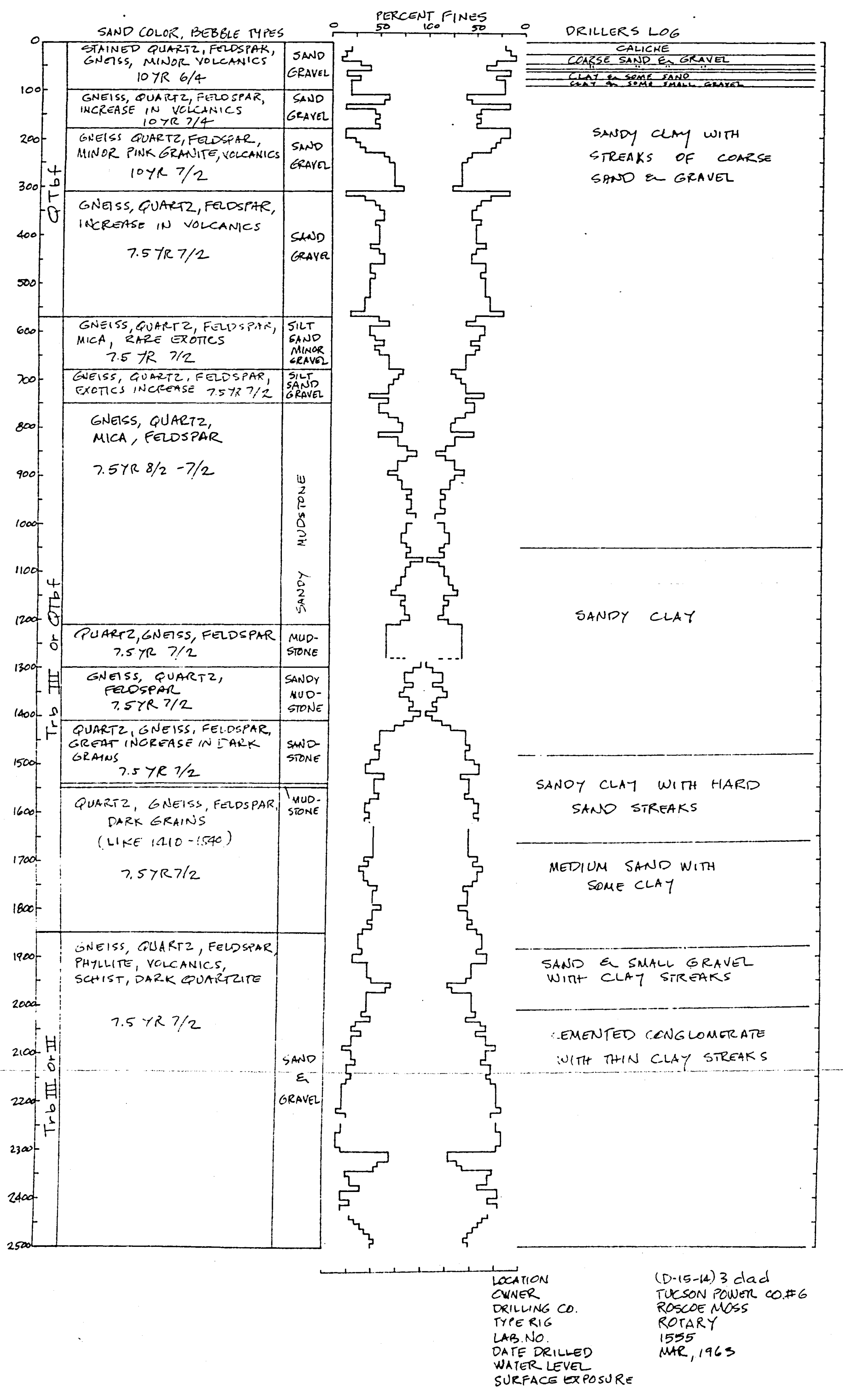




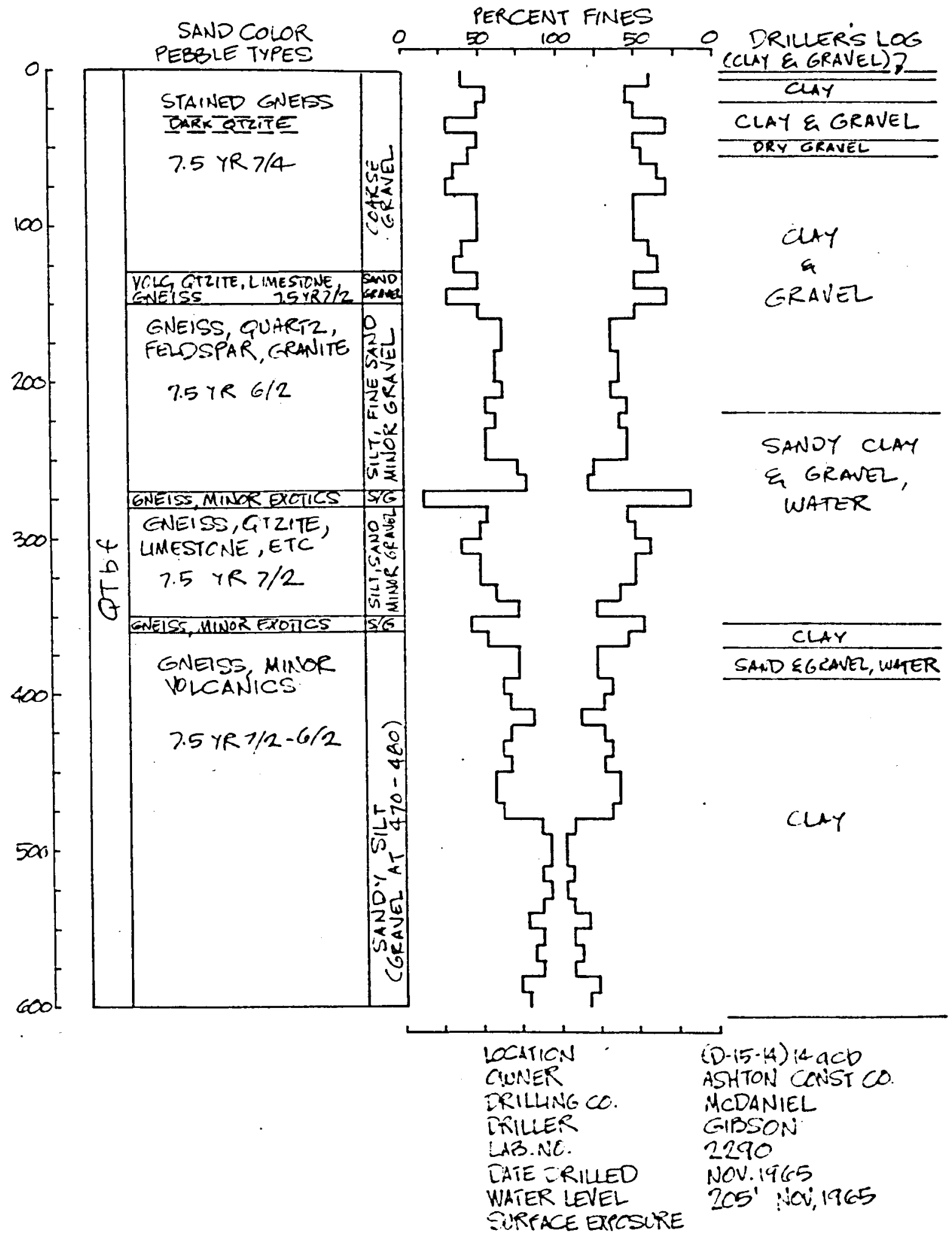




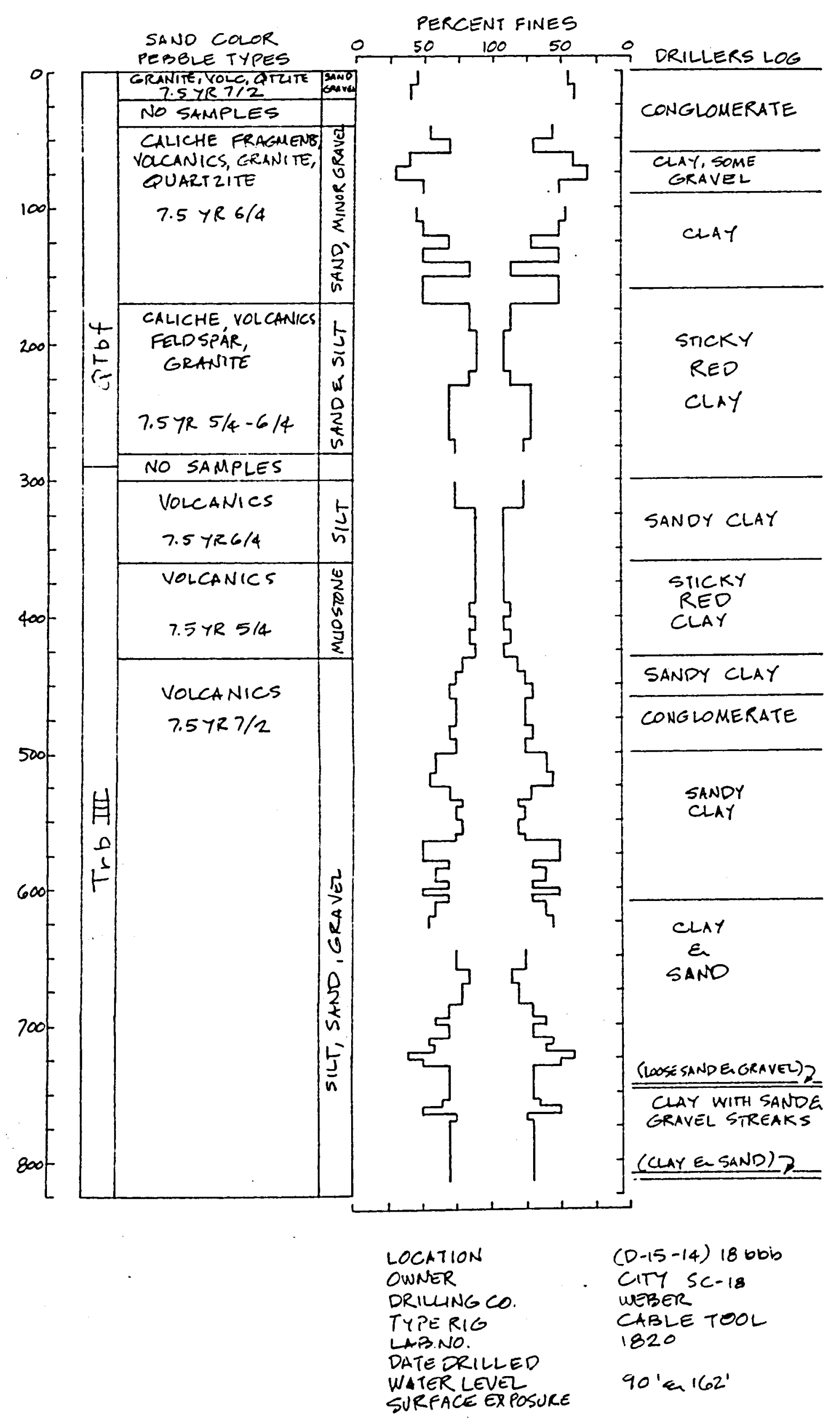




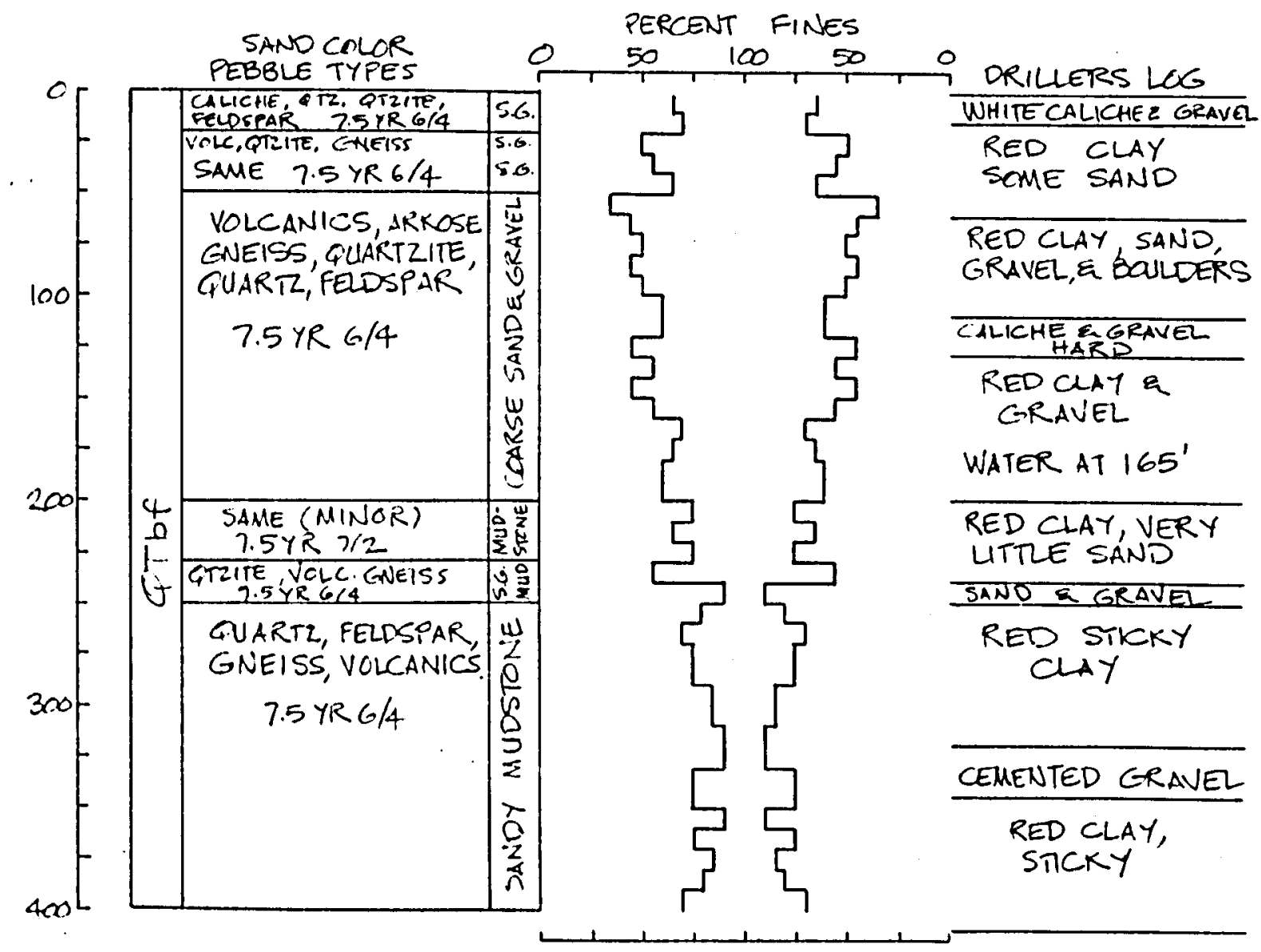

LOCATION

OWNER

RILLINGCO.

DRILLER

LAB.NO

DATE DRILLED

WATER LEVEL

SURFACE EXIOSURE
$(0-15-14) 27 \mathrm{bcc}$

AMER. CEMENT PIPE CO.

PISTOR

THCMPSON

2213

AUG.65

$155^{\prime}$ AUG. 65 


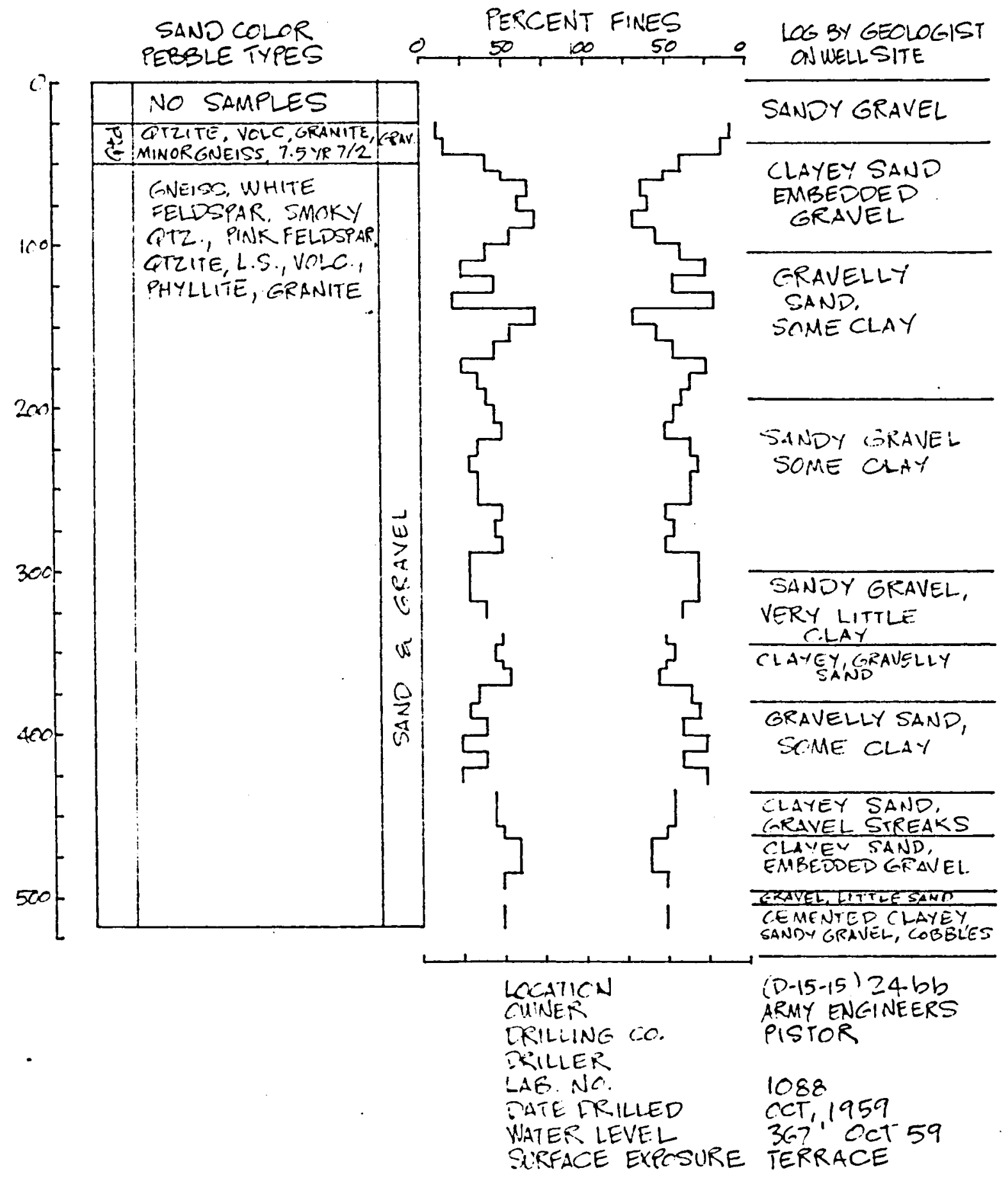




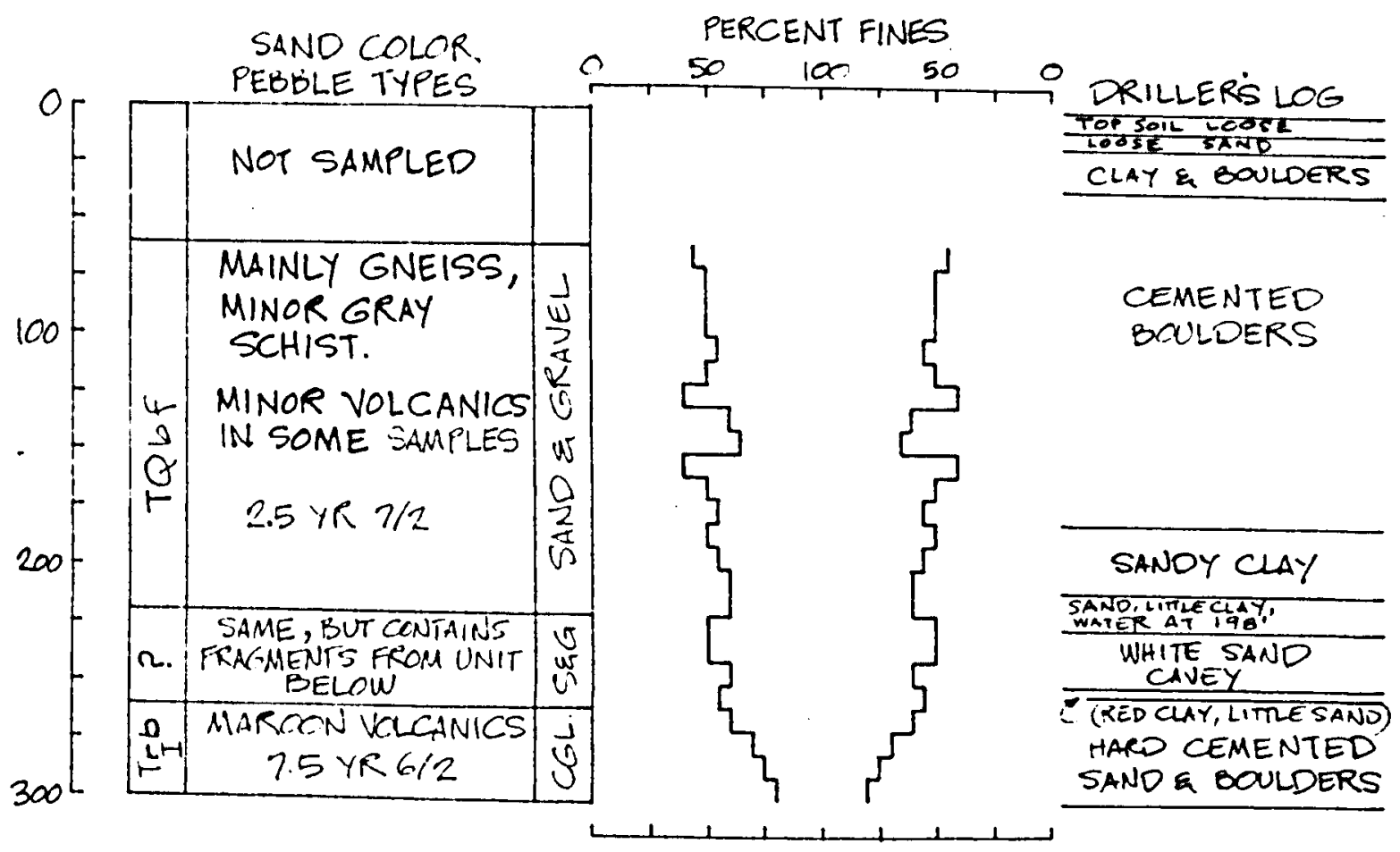

LOCATICN

CWNER

DRILLING CO.

$(D-15-16) 6 a c$

DRILLER

JR. LAVOI

LAB. NO

PISTCR

DATE ORILLED

GASTELLM

WATER LEVEL

SURFACE EXPCSURE

2283

NOV. 1965

$198^{\prime}, \mathrm{NOV} .65$ 


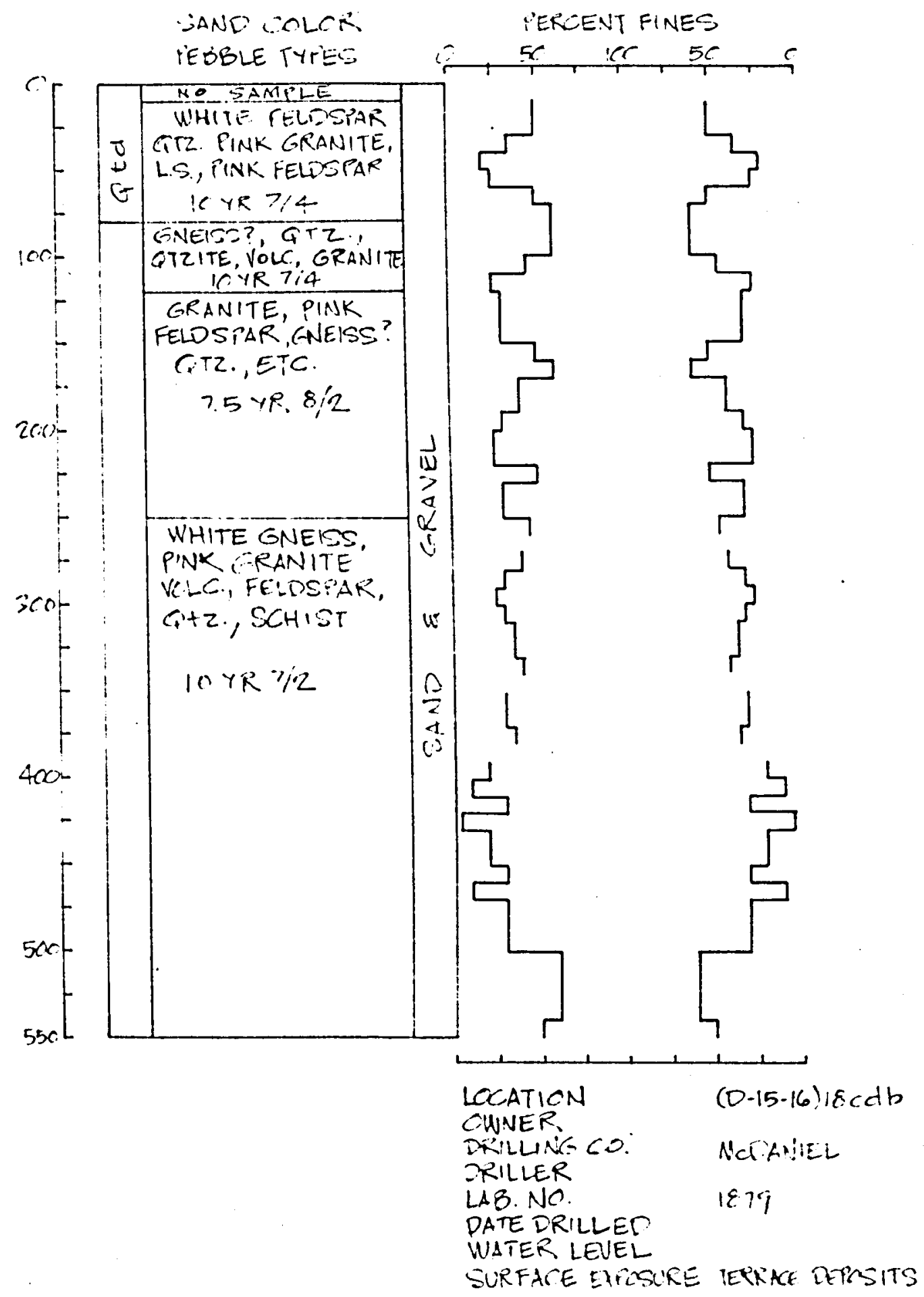




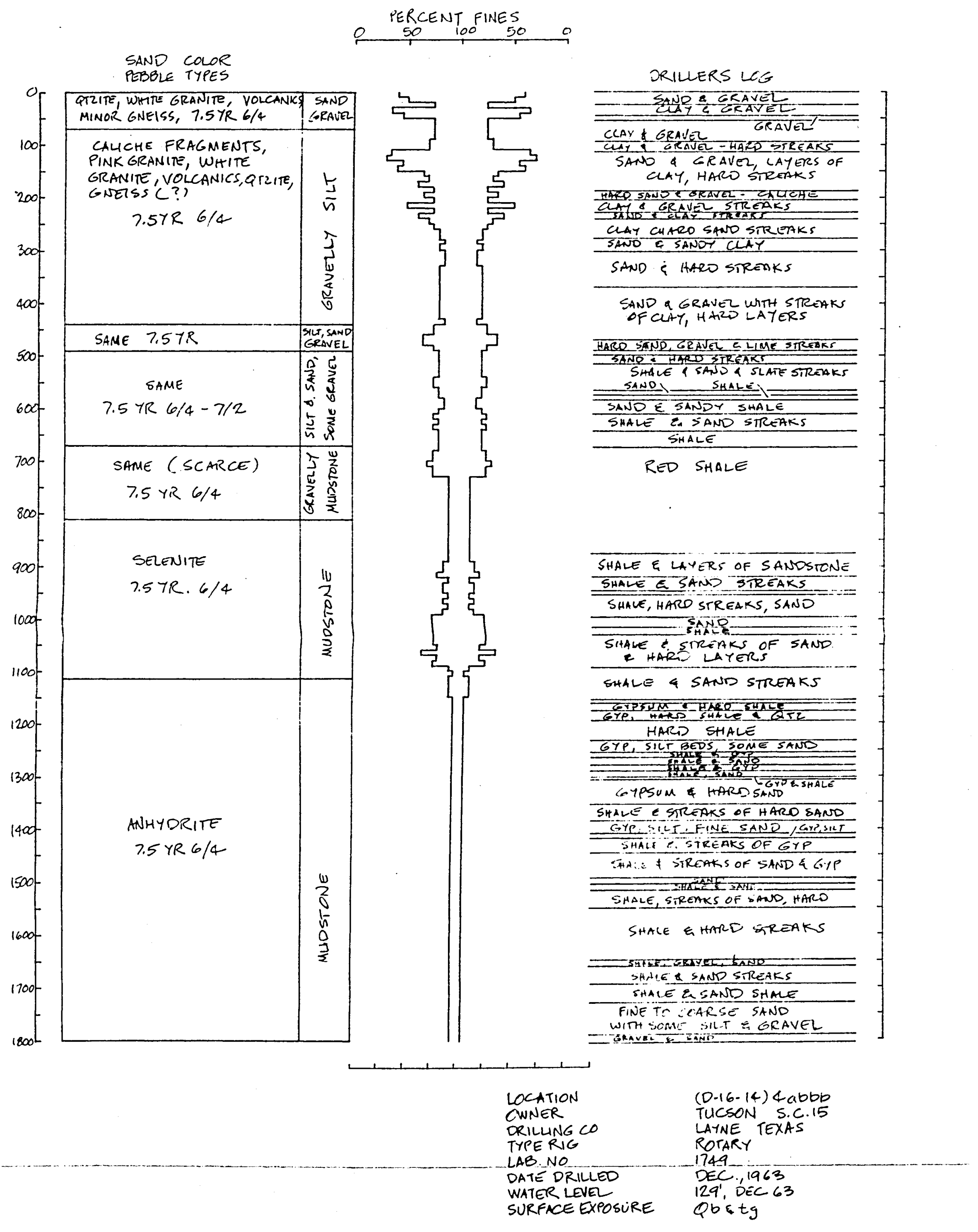




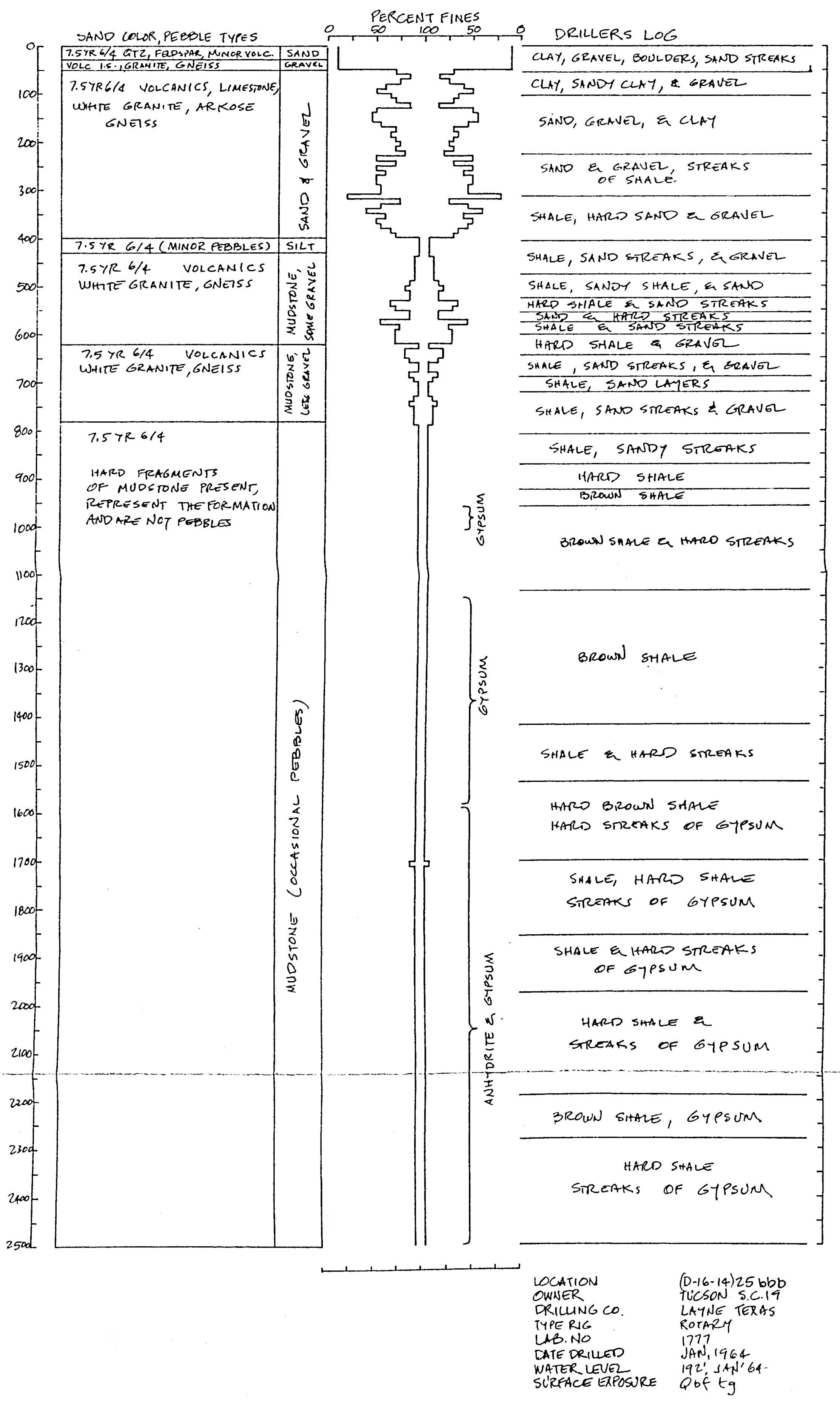




\section{LITERATURE CITED}

Acker, C. J., 1958, Geologic interpretations of a siliceous breccia in the Colossal Cave area, Pima County, Arizona: unpublished master's thesis, Univ. Arizona, $50 \mathrm{p}$.

Billings, M. P., 1942, Structural geology: New York, Prentice-Hall, Inc., $473 \mathrm{p}$.

Blake, W. P., 1908a, Geological sketch of the region of Tucson, Arizona, in MacDougal, D. T., Botanical features of North American deserts: Carnegie Inst. Washington Pub. 99, p. $45-68$.

$1908 \mathrm{~b}$, Note upon the Santa Catalina Gneiss, Arizona: Science, n. s., v. 28 , p. $379-380$.

Blissenbach, Erich, 1951, The geology of alluvial fans in Arizona: unpublished master's thesis, Univ. Arizona, 101 p.

Brennan, D. J., 1962, Tertiary sedimentary rocks and structures of the Cienega Gap area, Pima County, Arizona: Arizona Geol. Soc. Digest, v. 5, p. 45-57.

Bromfield, C. S., 1952, Some geologic features of the Santa Catalina Mountains: Arizona Geol. Soc., Guidebook for field trip excursions in southern Arizona, p. 51-55.

Butler, B. S., Grout, F. F., and Bromfield, C. S., 1952, Santa Catalina Mountains metamorphic area, trip 3 road log: Arizona Geol. Soc., Guidebook for field trip excursions in southern Arizona, p. 43-50.

Chew, R. T., 3d, 1962, The Mineta Formation, a middle Tertiary unit in southeastern Arizona: Arizona Geol. Soc. Digest, v. 5, p. $35-43$. 
Cloos, Ernst, 1946, Lineation-a critical review and annotated bibliography: Geol. Soc. America Mem. 18, 122 p.

Cooley, M. E., and Davidson, E. S., 1963, The Mogollon Highlands their influence on Mesozoic and Cenozoic erosion and sedimentation: Arizona Geol. Soc. Digest, v. 6, p. 7-35.

Cooper, J. R. , 1960, Some geologic features of the Pima mining district, Pima County, Arizona: U. S. Geol. Survey Bull. 1112C, 101 p.

1961, Turkey-Track Porphyry - a possible guide for correlation of Miocene rocks in southeastern Arizona: Arizona Geol. Soc. Digest, v. 4, p. 17-33.

Coulson, O. B., 1950, Geology of the Sweetwater Drive area and correlation of the Santa Cruz Valley gravels: unpublished master's thesis, Univ. Arizona, $71 \mathrm{p}$.

Damon, P. E., 1962, Correlation and chronology of ore deposits and volcanic rocks: Annual progress report no. 4, Research Division, U. S. Atomic Energy Comm., 35 p.

Damon, P. E., Erickson, R. C., and Livingston, D. E., 1963, K-Ar dating of basin and range uplift, Catalina Mountains, Arizona: Nuclear Geophysics, pub. 1075, p. 113-121.

Davidson, E. S., 1960, Geology of the eastern part of the Safford basin, Graham County, Arizona: Arizona Geol. Soc. Digest, v. 3, p. 123-126.

1961, Facies distribution and hydrology of intermontane basin fill, Safford basin, Arizona, in Geological Survey research 1961: U.S. Geol. Survey Prof. Paper 424-C, p. 151153.

Davis, W. M., 1931, The Santa Catalina Mountains, Arizona: Am. Jour. Sci., 5th ser., v. 22, p. 289-317.

Dietrich, R. V., 1960, Banded gneisses: Jour. Petrology, v. 1, p. 99-120.

DuBois, R. L., 1958, Geology of the Santa Catalina Mountains: Arizona Geol. Soc. Digest, v. 1, p. 15. 
1959a, Geology of the Santa Catalina Mountains: Arizona Geol. Soc., Southern Arizona Guidebook II, p. 107-116.

$1959 \mathrm{~b}$, Petrography and structure of a part of the gneissic complex of the Santa Catalina Mountains, Arizona: Arizona Geol. Soc., Southern Arizona Guidebook II, p. 117-126.

Fair, C. L., and Jinks, J. E., 1961, Santa Catalina foothills fault in the Pontatoc area: Arizona Geol. Soc. Digest, v. 4, p. 131132.

Galbraith, F. W., 1959, The Empire Mountains, Pima County, Arizona: Arizona Geol. Soc., Southern Arizona Guidebook II, p. 127-133.

Ganus, W. J., 1965, Lithologic and structural influences on the hydrodynamics of the Tucson basin, Arizona: unpublished master's thesis, Univ. Arizona, $37 \mathrm{p}$.

Heindl, L. A., 1959, Geology of the San Xavier Indian Reservation, Arizona: Arizona Geol. Soc., Southern Arizona Guidebook II, p. 153-159.

1962, Cenozoic geology of Arizona-a 1960 resume: Arizona Geol. Soc. Digest, v. 5, p. 9-24.

1963, Cenozoic geology in the Mammoth area, Pinal County, Arizona: U.S. Geol. Survey Bull. 1141-E, 41 p.

Hernon, R. M., 1932, Pegmatite rocks of the Catalina-Rincon Mountains, Arizona: unpublished master's thesis, Univ. Arizona, $65 \mathrm{p}$.

Kerns, J. R., 1958, Geology of the Agua Verde Hills, Pima County, Arizona: unpublished master's thesis, Univ. Arizona, $69 \mathrm{p}$.

Kidwai, Z. U., 1957, The relationship of ground water to alluvium in the Tucson area: unpublished master's thesis, Univ. Arizona, $55 \mathrm{p}$.

Knechtel, M. M., 1938, Geology and ground-water resources of the valley of Gila River and San Simon Creek, Graham County, Arizona: U.S. Geol. Survey Water-Supply Paper 796-F, p. 181-222. 
Lance, J. F., 1960, Stratigraphic and structural position of Cenozoic fossil localities in Arizona: Arizona Geol. Soc. Digest, v. 3, p. 155-159.

Laughlin, A. W., 1959, Petrology of the Molino basin area, Santa Catalina Mountains, Arizona: unpublished master's thesis, Univ. Arizona, 59 p.

Layton, D. W. , 1957, Stratigraphy and structure of the southwestern foothills of the Rincon Mountains, Pima County, Arizona: unpublished master's thesis, Univ. Arizona, $87 \mathrm{p}$.

Maddox, G. E., 1960, Subsurface geology along northwest Rillito Creek: unpublished master's thesis, Univ. Arizona, $232 \mathrm{p}$.

McColly, R. A., 1961, Geology of the Saguaro National Monument area, Pima County, Arizona: unpublished master's thesis, Univ. Arizona, 80 p.

Moore, B. N., Tolman, C. F., Jr., Butler, B. S., and Hernon, R. M. , 1941, Geology of the Tucson quadrangle: U.S. Geol. Survey open-file report, $20 \mathrm{p}$.

Munsell Color Company, Inc., 1954, Munsell Soil Color Charts: Baltimore, Maryland, Munsell Color Co., Inc.

Peirce, F. L., 1958, Structure and petrography of part of the Santa Catalina Mountains: unpublished doctoral thesis, Univ. Arizona, 86 p.

Peterson, R. C., 1963, Structural geology of the Sabino Canyon fold, Santa Catalina Mountains, Pima County, Arizona: unpublished master's thesis, Univ. Arizona, 37 p.

Pilkington, H. D., 1962, Structure and petrology of a part of the east flank of the Santa Catalina Mountains, Pima County, Arizona: unpublished doctoral thesis, Univ. Arizona, $120 \mathrm{p}$.

Ransome, F. L., 1916, Some Paleozoic sections in Arizona and their correlation: U. S. Geol. Survey Prof. Paper 98, p. 133-166.

Richard, Kenyon, and Courtright, J. H., 1960, Some CretaceousTertiary relationships in southeastern Arizona and New Mexico: Arizona Geol. Soc. Digest, v. 3, p. 1-7. 
Schwalen, H. C., and Shaw, R. J., 1957, Ground-water supplies of Santa Cruz Valley of southern Arizona between Rillito Station and the International Boundary: Univ. Arizona Agr. Expt. Sta. Bull. 288, 119 p.

Smith, G. E. P., 1910, Ground water supply and irrigation in the Rillito Valley, Arizona: Univ. Arizona Agr. Expt. Sta. Bull. $64,244 \mathrm{p}$.

1938, The physiography of Arizona valleys and the occurrence of ground water: Univ. Arizona Agr. Expt. Sta. Tech. Bull. 77, $91 \mathrm{p}$.

Streitz, Robert, 1962, Subsurface stratigraphy and hydrology of the Rillito Creek-Tanque Verde Wash area, Tucson, Arizona: unpublished master's thesis, Univ. Arizona, $60 \mathrm{p}$.

The Rillito Creek Hydrologic Research Committee of the University of Arizona and the U.S. Geological Survey, 1959, Capturing additional water in the Tucson area: U. S. Geol. Survey open-file report, $59 \mathrm{p}$.

Tolman, C. F., Jr., 1909, Erosion and deposition in southern Arizona bolson region: Jour. Geology, v. 17, p. 136-163.

Tuan, Yi-Fu, 1959, Pediments in southeastern Arizona: Univ. California Pub. Geog., v. 13, 163 p.

Voelger, Klaus, 1953, Cenozoic deposits in the southern foothills of the Santa Catalina Mountains near Tucson, Arizona: unpublished master's thesis, Univ. Arizona, $101 \mathrm{p}$.

Wilson, E. D., 1962, A resume of the geology of Arizona: Arizona Bur. Mines Bull. 171, 140 p.

Wilson, E. D., Moore, R. T., and O'Haire, R. T., 1960, Geologic map of Pima and Santa Cruz Counties, Arizona: Arizona Bur. Mines. 

$x^{3}+3 x=$

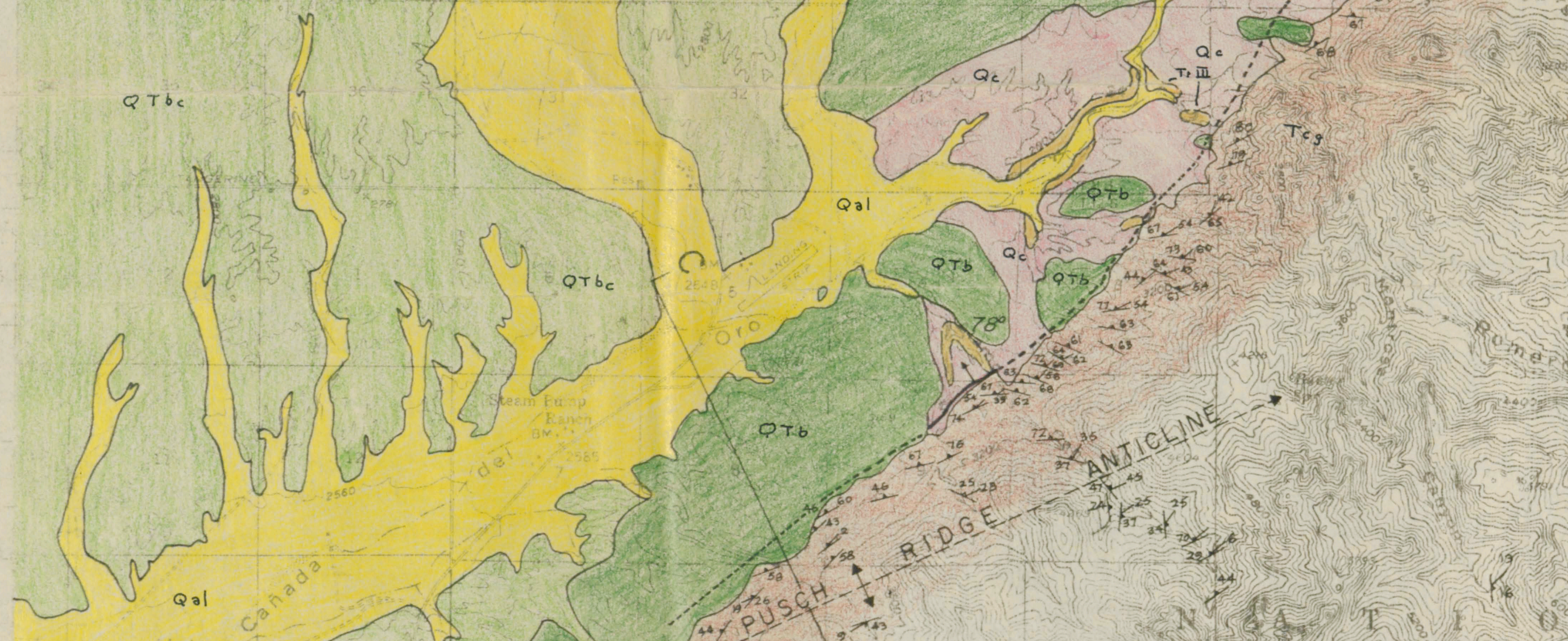

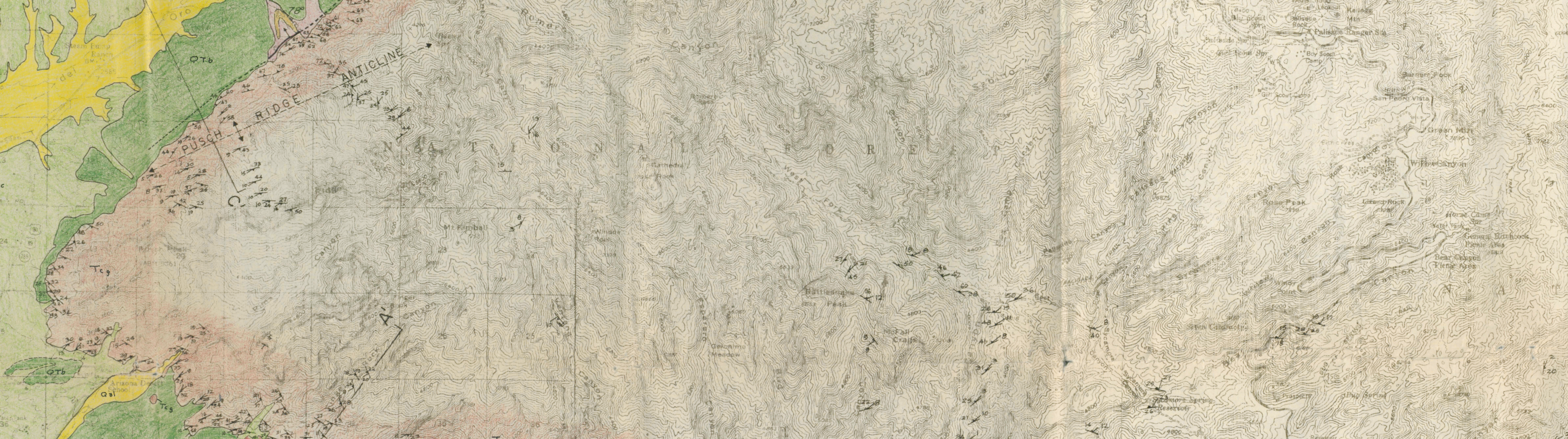

cese $\int_{5}$

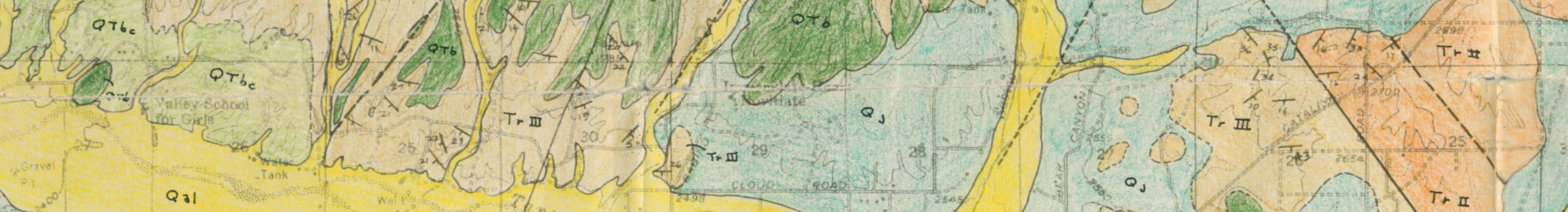

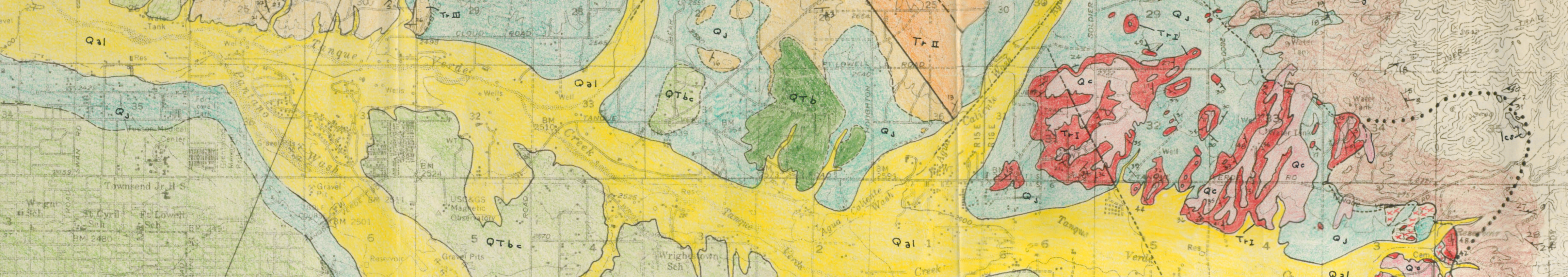

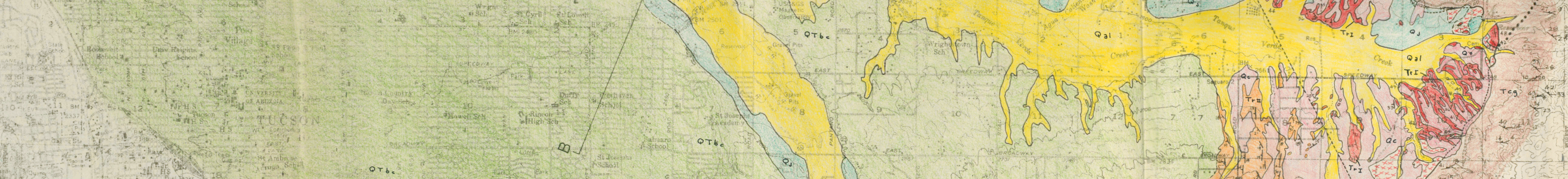

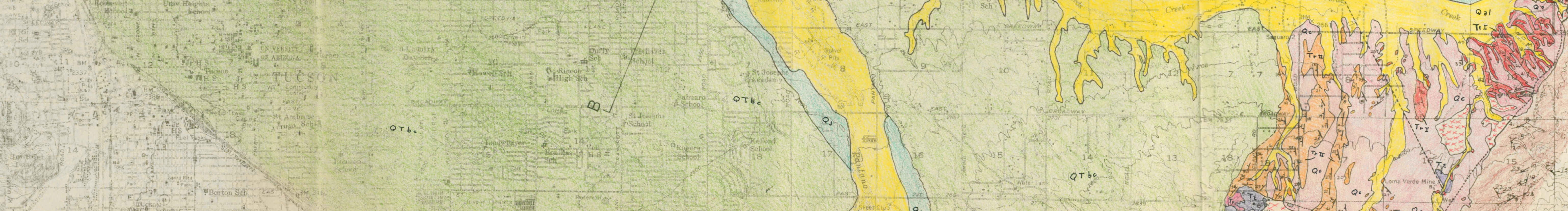

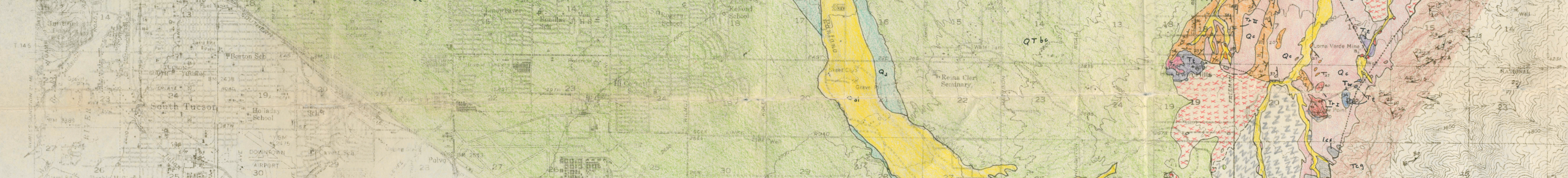

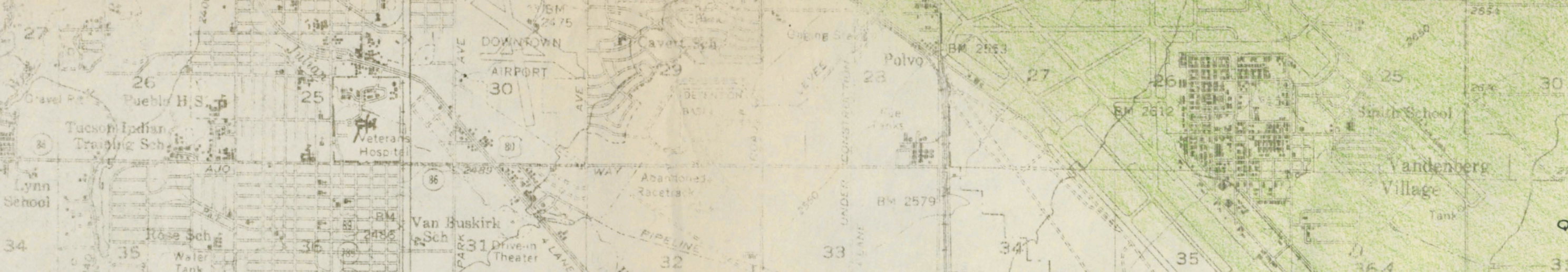


A
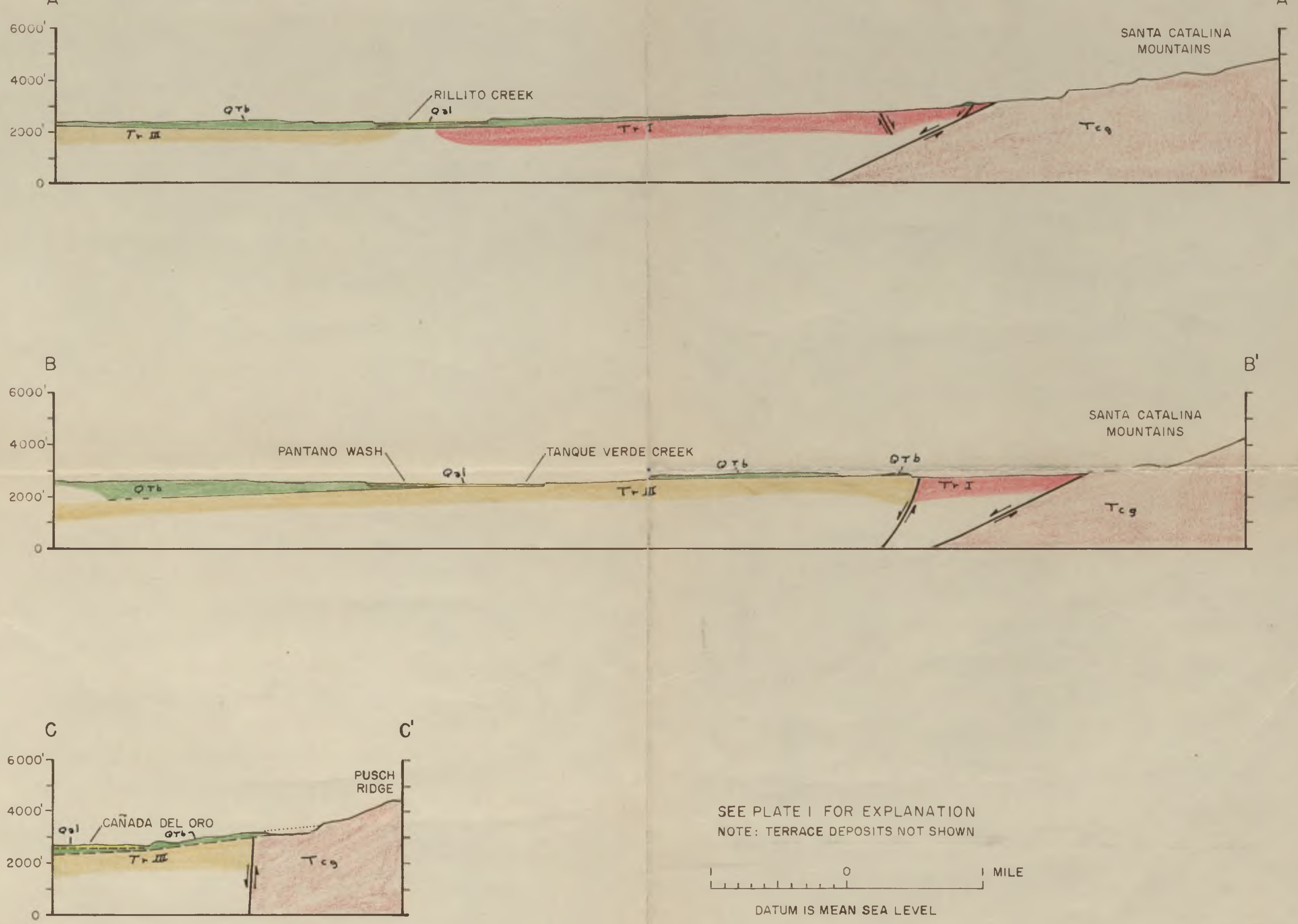

SEE PLATE I FOR EXPLANATION NOTE: TERRACE DEPOSITS NOT SHOWN

I

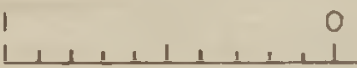

0

DATUM IS MEAN SEA LEVEL 


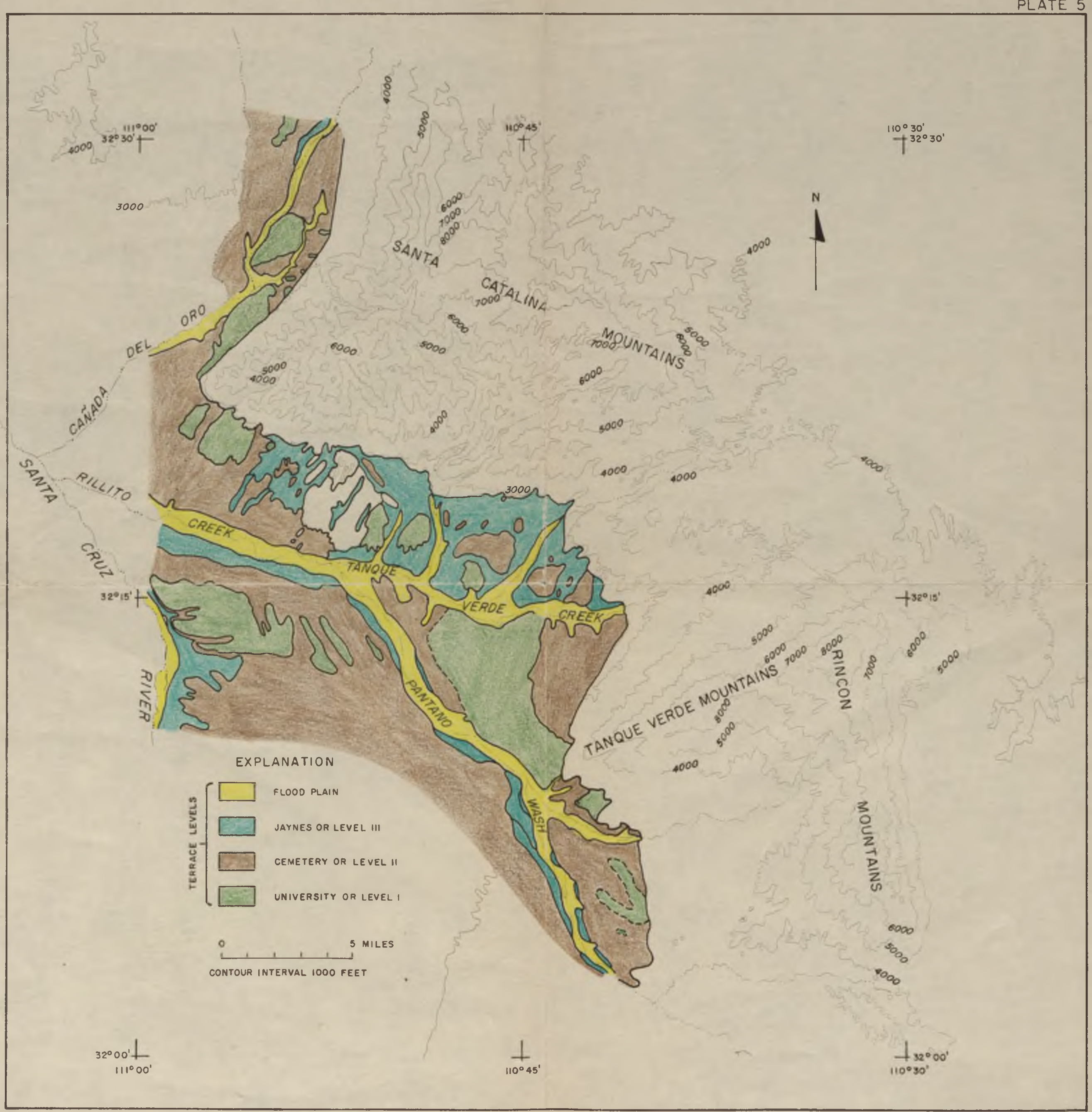

MAP SHOWING TERRACES IN THE NORTHERN, EASTERN, AND CENTRAL PARTS OF THE TUCSON BASIN, ARIZONA. 


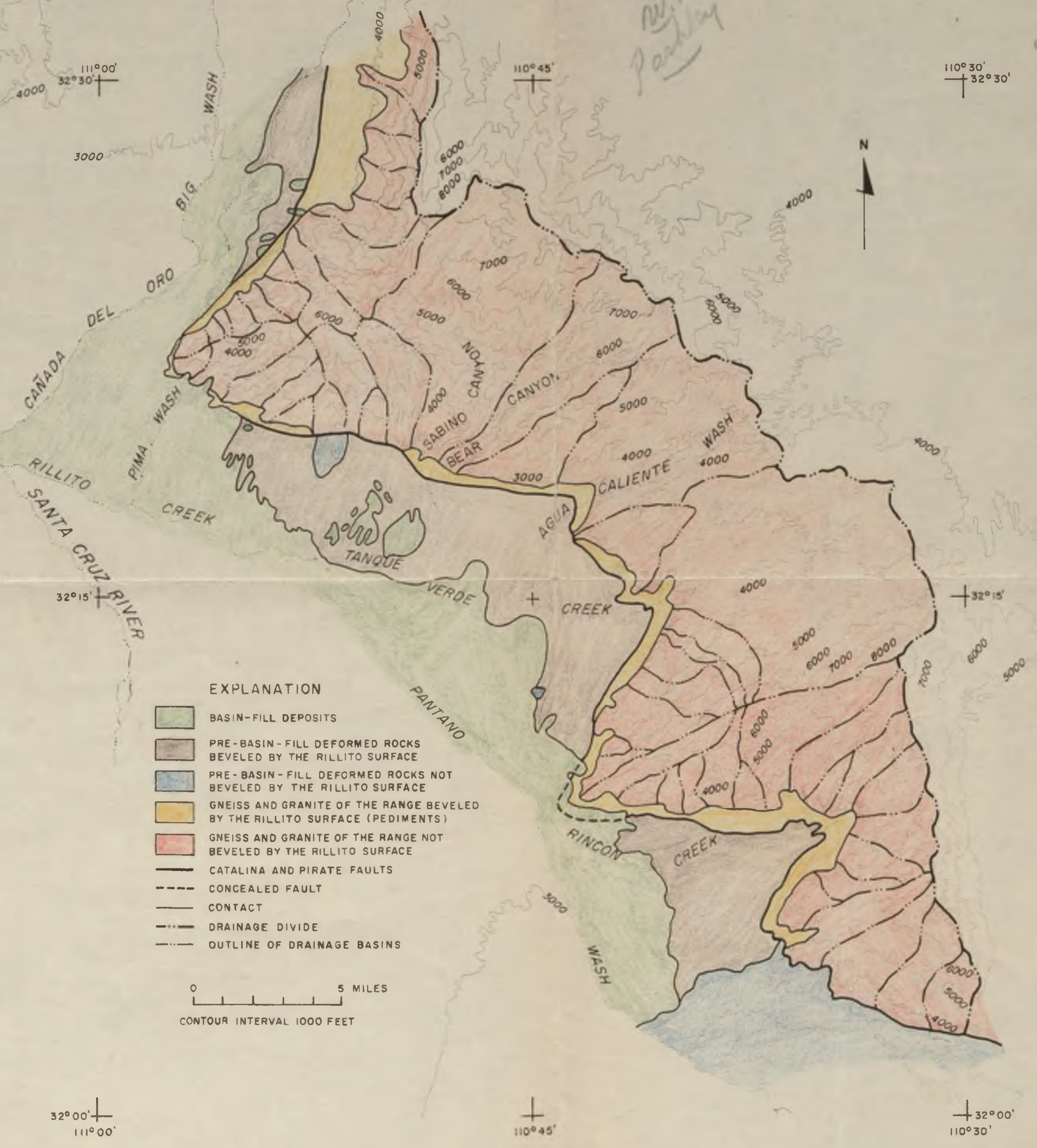

MAP SHOWING̈ THE EXTENT OF THE BASIN-FILL DEPOSITS, THE RILLITO SURFACE, AND DRAINAGE BASINS IN THE NORTHERN AND EASTERN PARTS OF THE TUCSON BASIN, ARIZONA. 


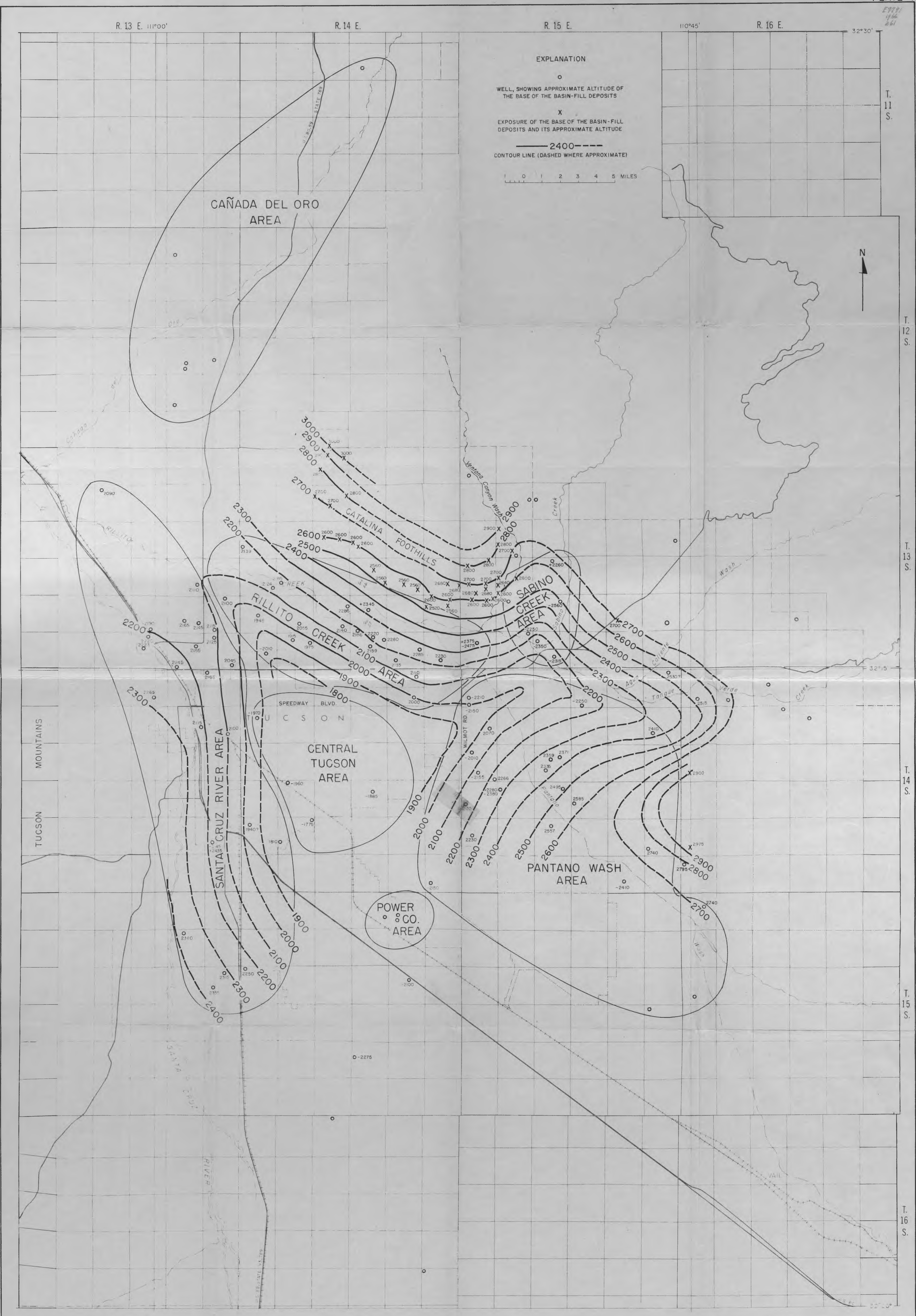

